\title{
Demonstration of Natural Gas Engine Driven Air Compressor at Army Industrial Facilities
}

Mike C.J. Lin, Stephen W. Aylor, Robert T. Lorand, John C Skelton, Hank Van Ormer, Paul A. Wenner, George Powers, Donald Carlson, William R. King, and John F. Westerman
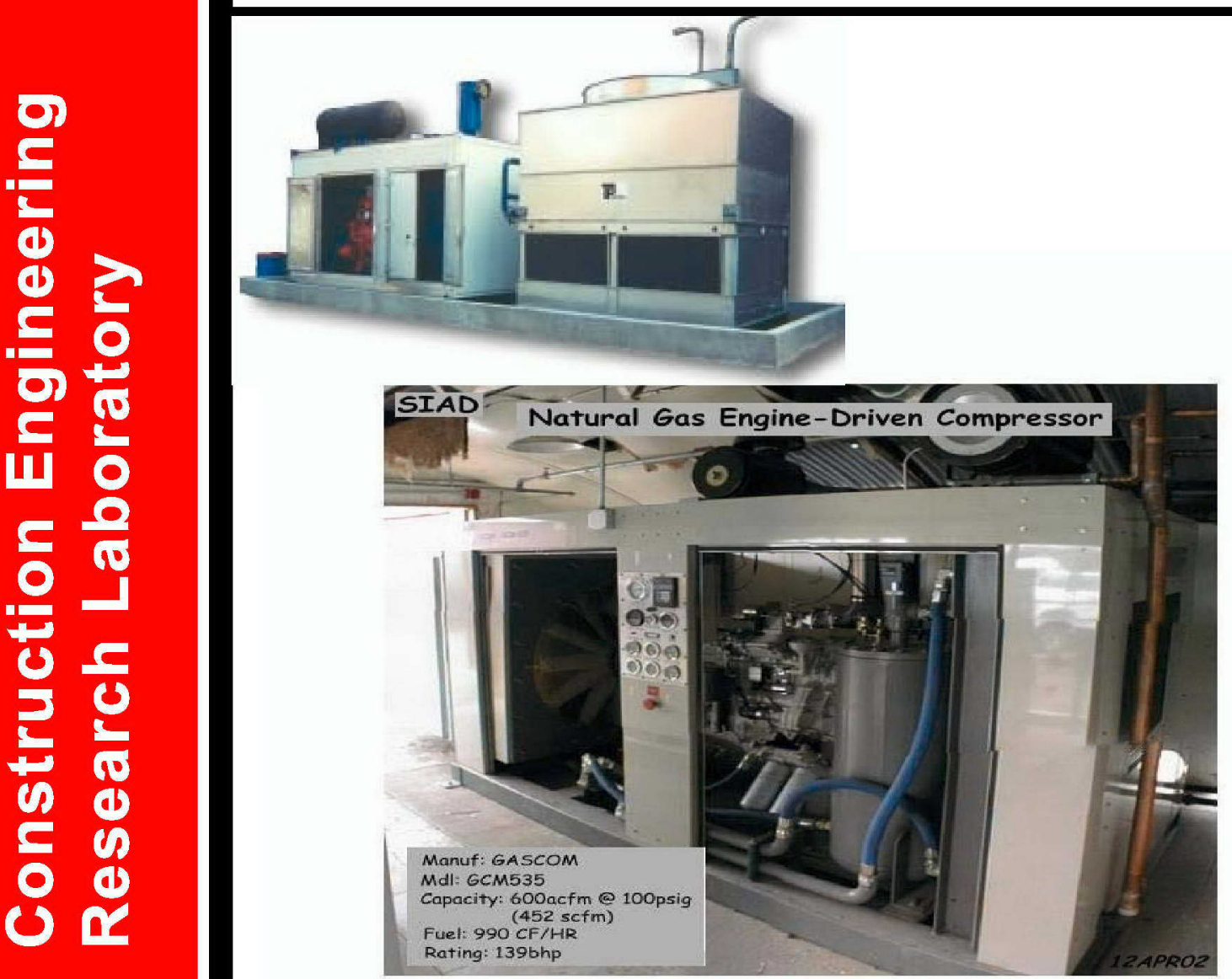


\section{Foreword}

This study was conducted for the Headquarters, U.S. Army Materiel Command (AMC) under Military Interdepartmental Purchase Requests (MIPRs) No. 0G6AR4D167 and 1B6AR4D125, Work Units K90 and G701, "Natural Gas Air Compressor Demonstration." The technical monitor was Robert Reeves, AMXISC, AMC Installations \& Services Activity.

This work was performed by the Energy Branch (CF-E), of the Facilities Division (CF), Construction Engineering Research Laboratory (CERL). The CERL Principal Investigator was Dr. Mike C.J. Lin. The demo at Picatinny and Watervliet Arsenals was done under contract No. DACA88-98-0007-0002 by Technology and Management Services, Inc. (TMSI); Xenergy Inc. Stephen W. Aylor and George Powers are associated with TMSI. John Skelton, Hank Van Ormer, and Paul Wenner are associated with Xenergy. The demo at SIAD was done by Science Applications International Corporation (SAIC) under contract No. DACA88-98003-0010. Robert T. Lorand, Donald Carlson, William R. King, and John F. Westerman are associated with SAIC. Appreciation is owed to Richard Sloboda (Picatinny Arsenal), Vanessa Duenas (Watervliet Arsenal), and Daniel Moore (Sierra Army Depot) for their support of this demo. The technical editor was William J. Wolfe, Information Technology Laboratory. Dr. Thomas Hartranft is Chief, CEERD-CF-E, and L. Michael Golish is Chief, CEERD-CF. The associated Technical Director was Gary W. Schanche.

The Director of CERL is Dr. Alan W. Moore. CERL is an element of the U.S. Army Engineer Research and Development Center (ERDC), U.S. Army Corps of Engineers. The Commander and Executive Director of ERDC is COL John Morris III, EN and the Director of ERDC is Dr. James R. Houston.

\section{DISCLAIMER}

The contents of this report are not to be used for advertising, publication, or promotional purposes. Citation of trade names does not constitute an official endorsement or approval of the use of such commercial products. All product names and trademarks cited are the property of their respective owners.

The findings of this report are not to be construed as an official Department of the Army position unless so designated by other authorized documents.

DESTROY THIS REPORT WHEN IT IS NO LONGER NEEDED. DO NOT RETURN IT TO THE ORIGINATOR. 


\section{Contents}

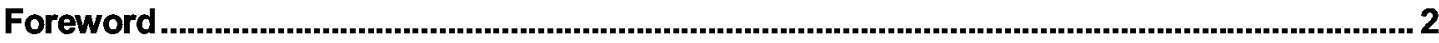

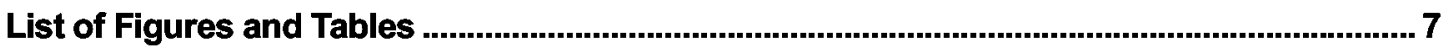

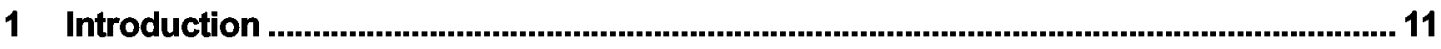

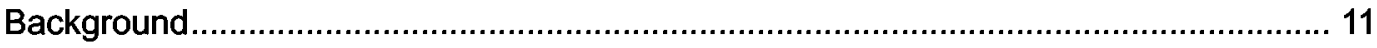

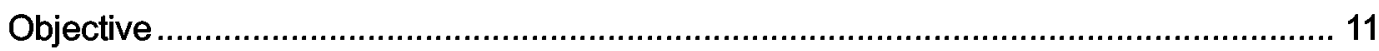

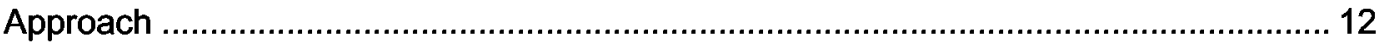

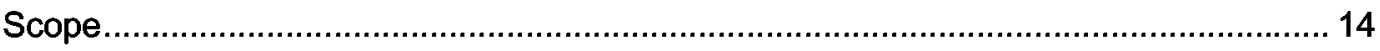

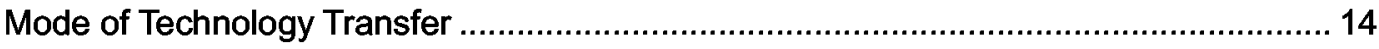

Units of Weight and Measure .............................................................................. 15

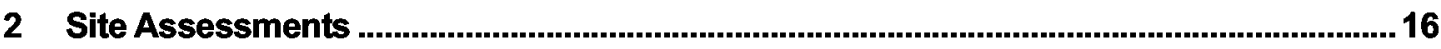

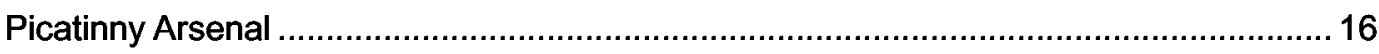

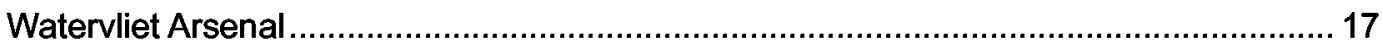

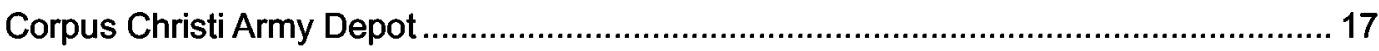

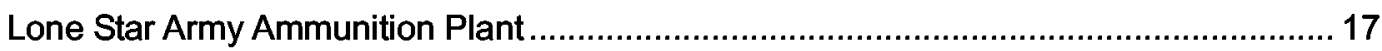

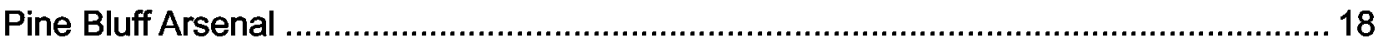

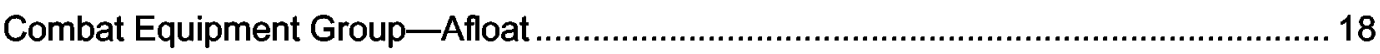

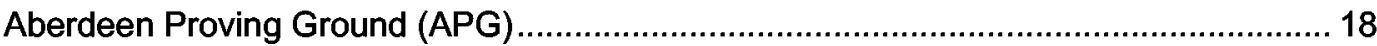

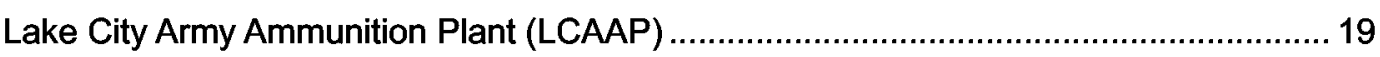

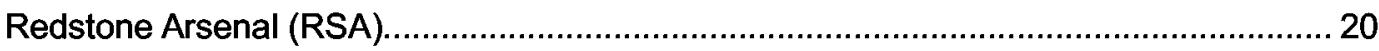

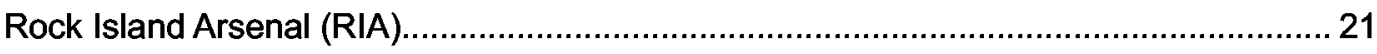

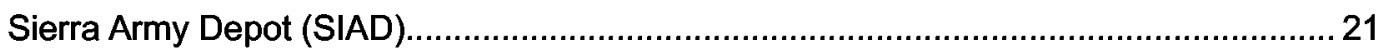

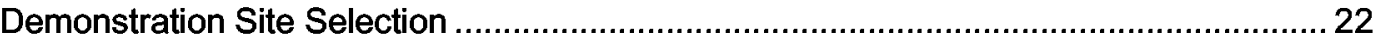

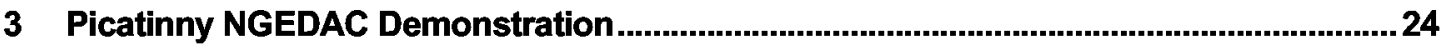

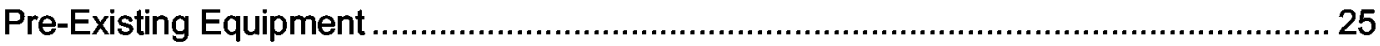

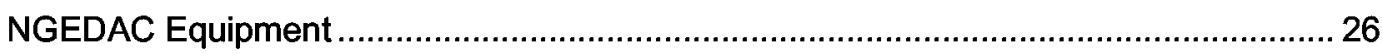

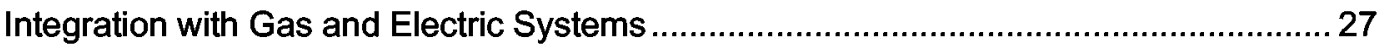

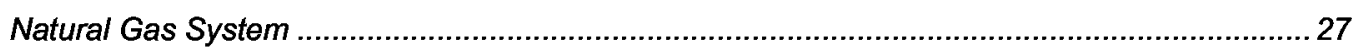

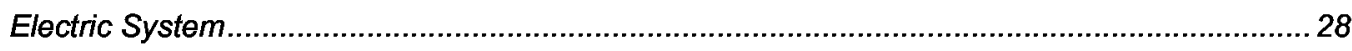

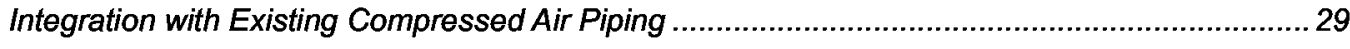

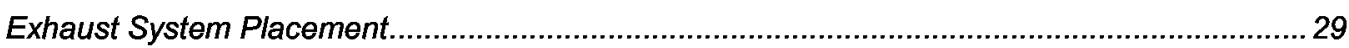

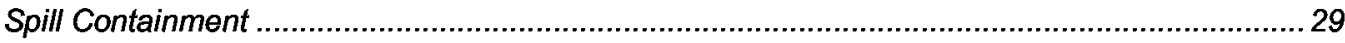

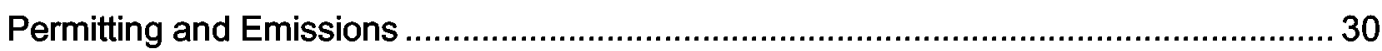


Compressor Efficiency and Cost Analysis Results for Picatinny ................................. 30

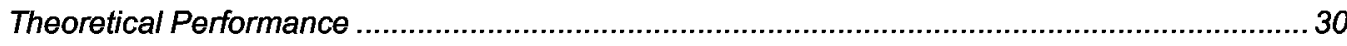

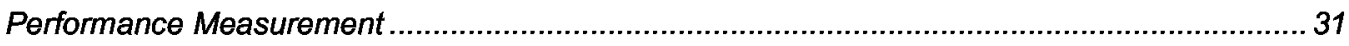

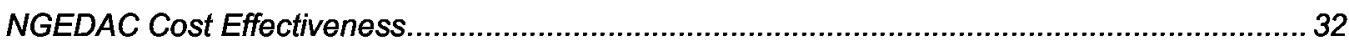

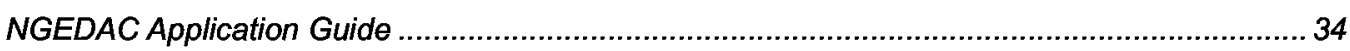

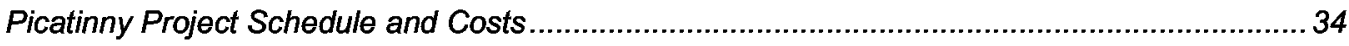

Picatinny Level II Site Visit Summary .................................................................................. 35

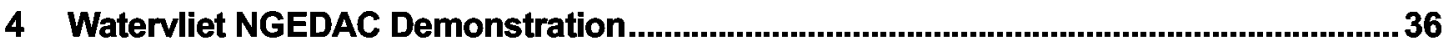

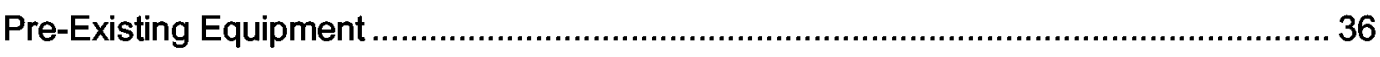

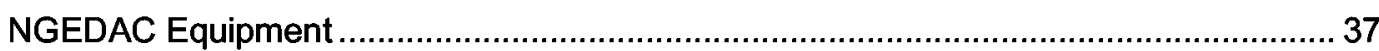

Natural Gas Engine and Compressor Unit ............................................................................. 37

Closed Loop Cooling System and Evaporative Tower ........................................................ 39

Integration with Natural Gas Fuel and Electric Power Feeds ..................................... 39

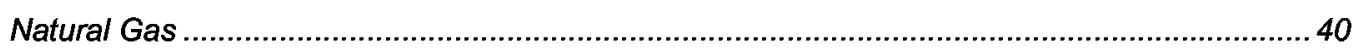

Electric Power

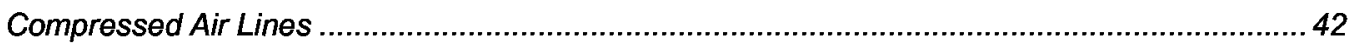

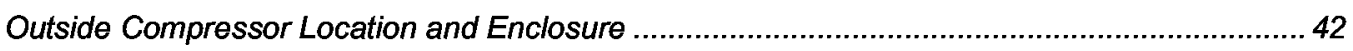

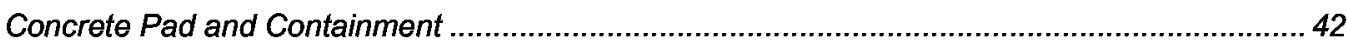

Canopy Protection of Concrete Containment System From Weather............................. 43

Closed Loop Cooling System and Evaporative Tower .................................................43 43

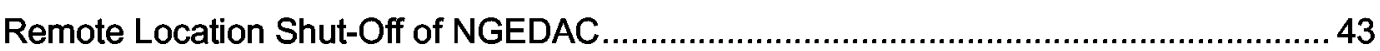

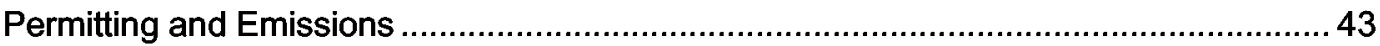

Compressor Efficiency and Cost Analysis Results for Watervliet...................................44

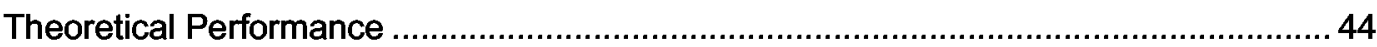

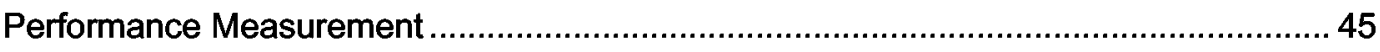

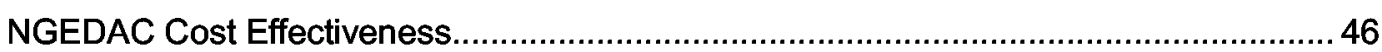

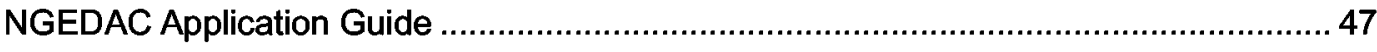

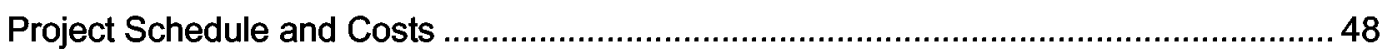

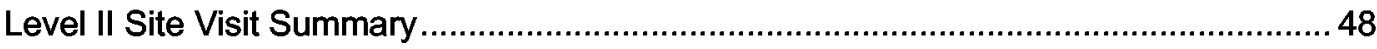

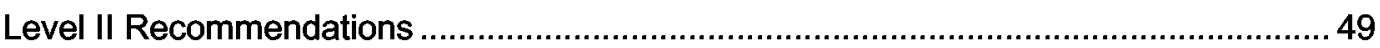

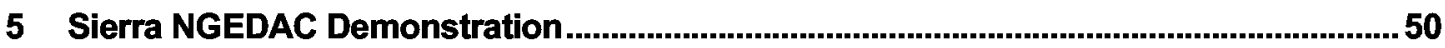

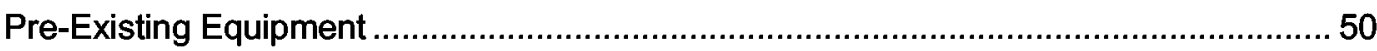

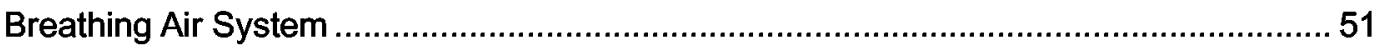

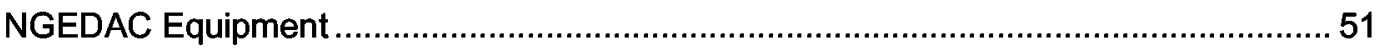

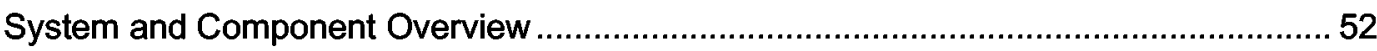

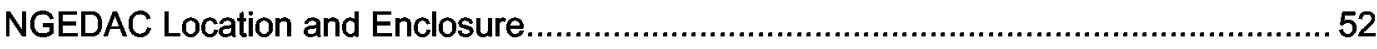

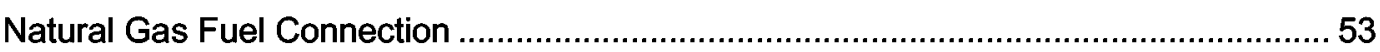

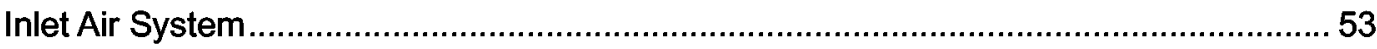

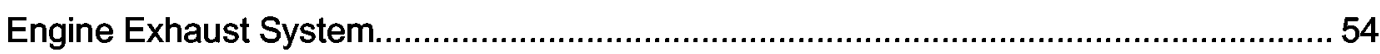

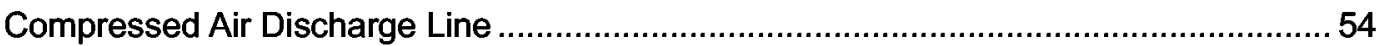




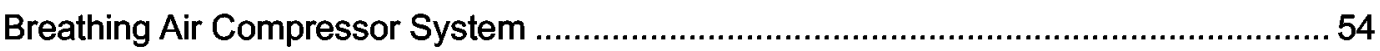

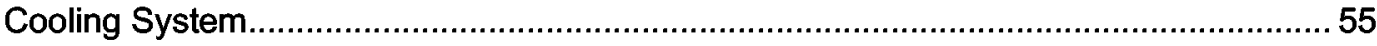

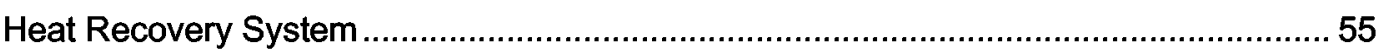

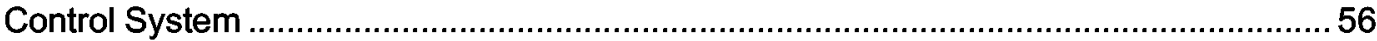

Backup Control-Sequencing with Other Stationary Compressors ............................56

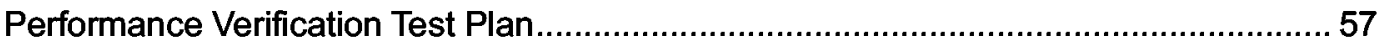

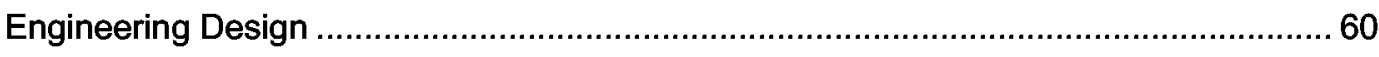

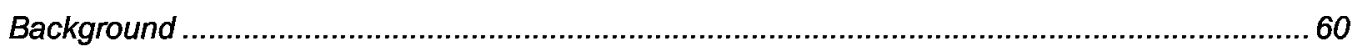

Basic Features and Changes Relative to Conceptual Design ...................................................61

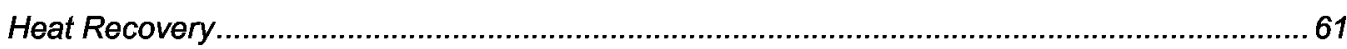

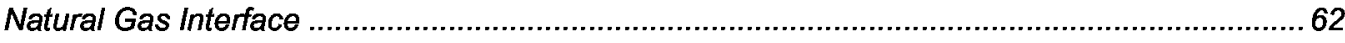

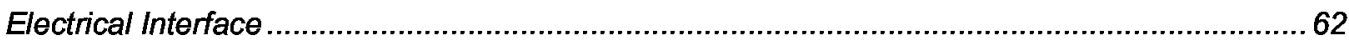

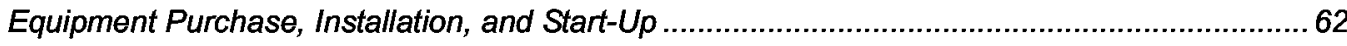

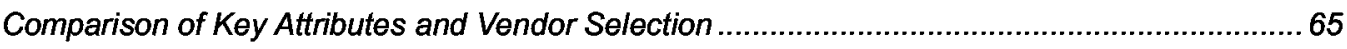

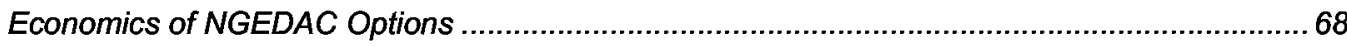

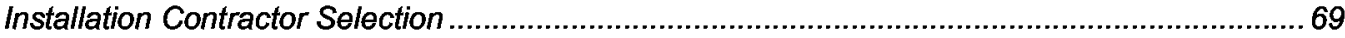

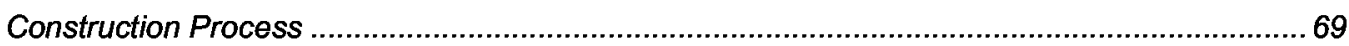

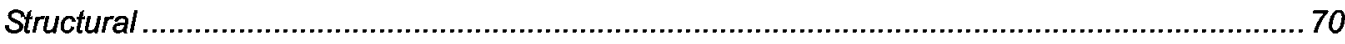

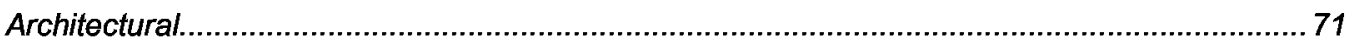

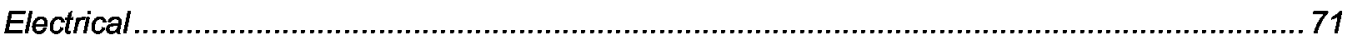

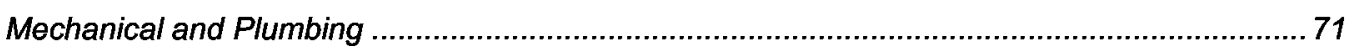

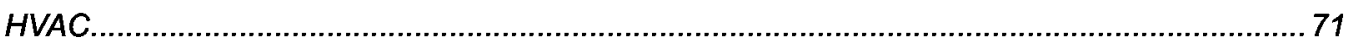

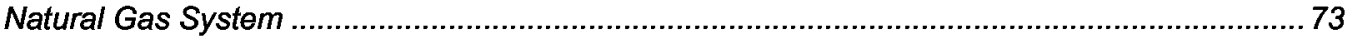

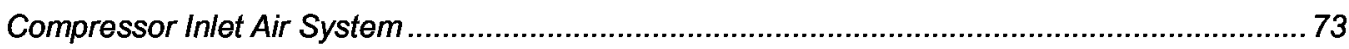

Compressed Air System .................................................................................................. 74

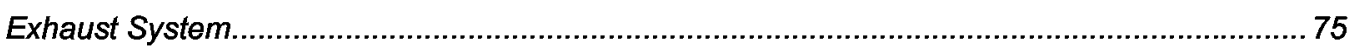

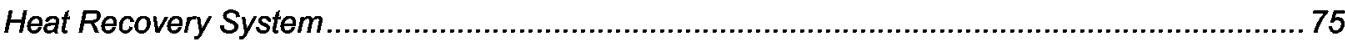

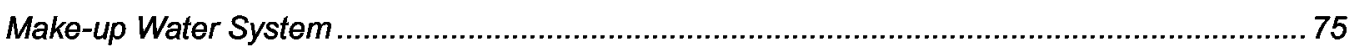

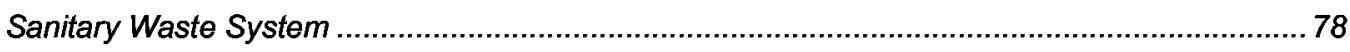

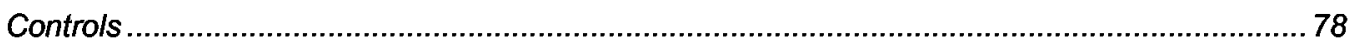

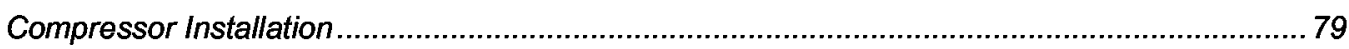

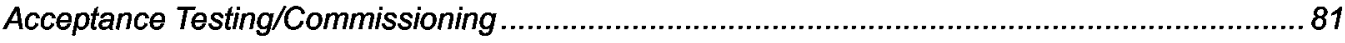

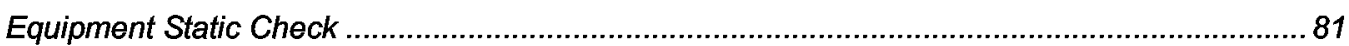

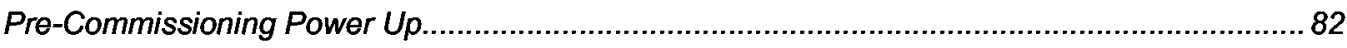

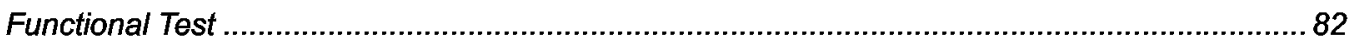

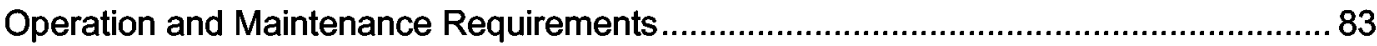

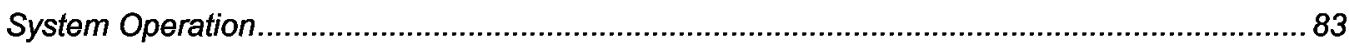

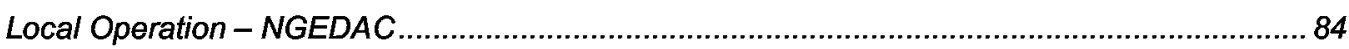

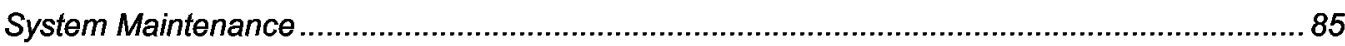

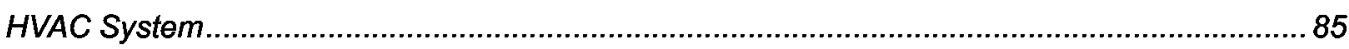

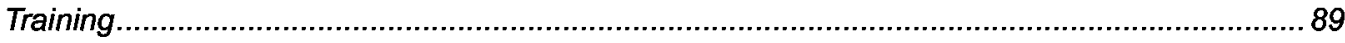

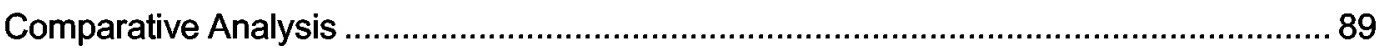




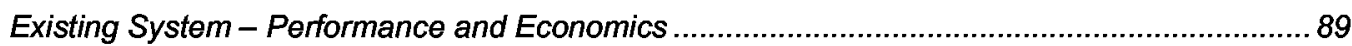

NGEDAC System-Performance and Economics ......................................................... 94

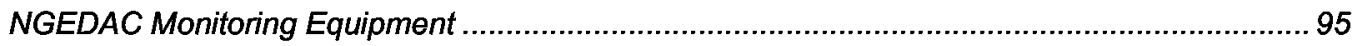

Monitoring System Enclosure Layout ..................................................................... 96

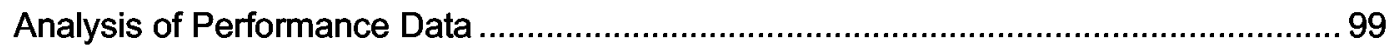

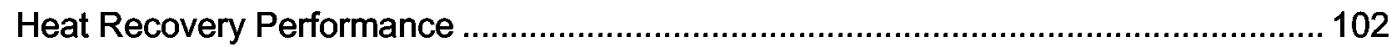

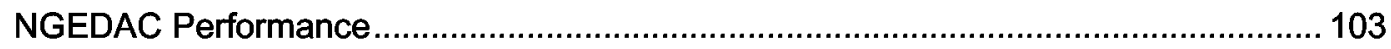

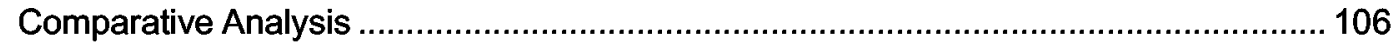

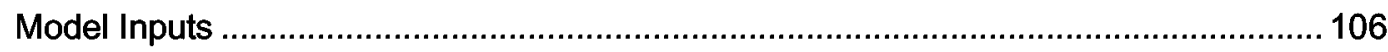

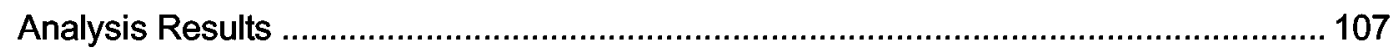

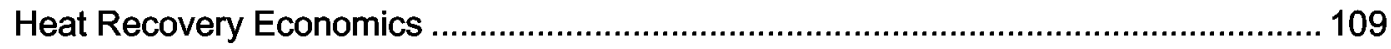

Economics of New/Replacement vs. Retrofit Application ...................................... 110

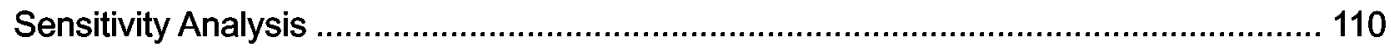

6 Discussion ....................................................................................................................... 114

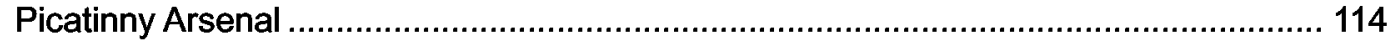

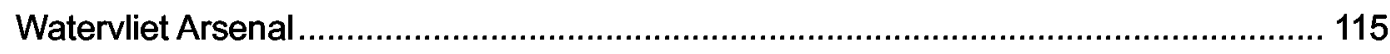

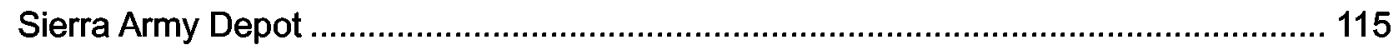

7 Conclusions and Recommendations ............................................................................. 117

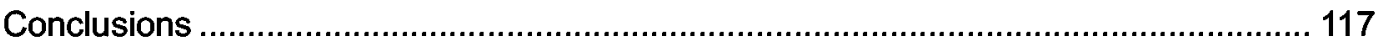

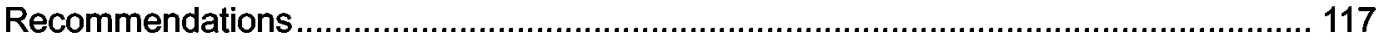

Appendix A: Demonstration at Sierra Army Depot, Request for Quotation (RFQ) for

Compressors ................................................................................................................120

Appendix B: Request for Quotation (RFQ) for Installation Contractor ................................ 125

Appendix C: Maintenance Contracts for NGEDAC at SIAD............................................. 137

Appendix D: Natural Gas Engine Driven Air Compressor Data Logger Software............. 139

CERL Distribution ......................................................................................................... 146

Report Documentation Page ..................................................................................................... 147 


\section{List of Figures and Tables}

\section{Figures}

1 Dearing Ultra Air Model GSR-125LA NGEDAC installed at Picatinny Arsenal ......... 26

$2 \quad$ Picatinny Arsenal natural gas use: daily totals ................................................... 32

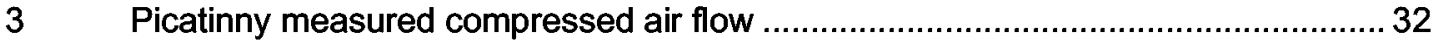

$4 \quad$ Dearing Ultra Air Model GSR-300LW NGEDAC installed at WVA ...........................39

$5 \quad$ Watervliet Arsenal natural gas use: daily totals.................................................... 45

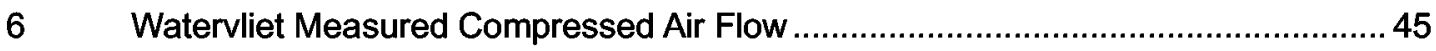

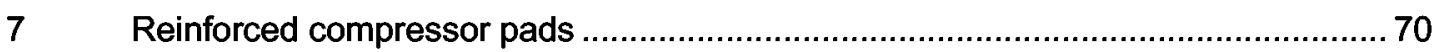

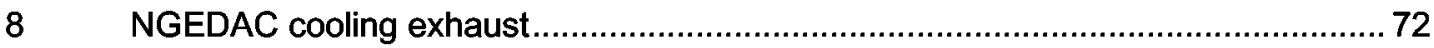

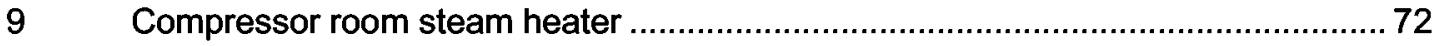

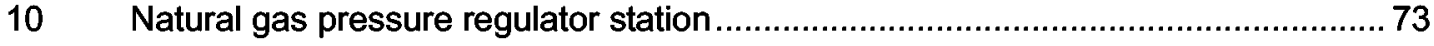

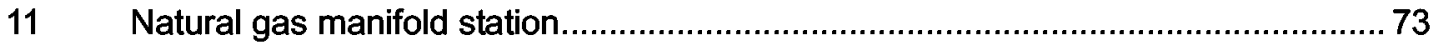

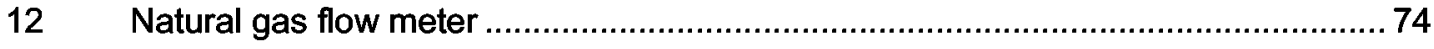

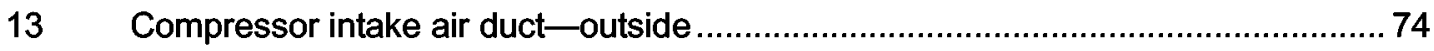

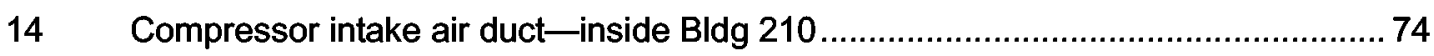

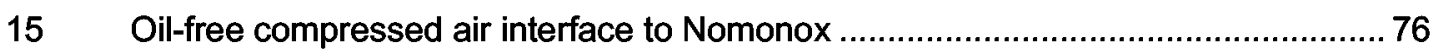

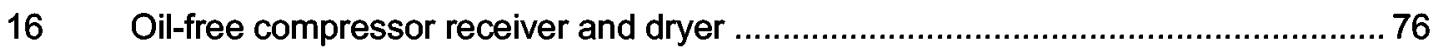

$17 \quad$ NGEDAC exhaust muffler/catalytic converter ...................................................... 76

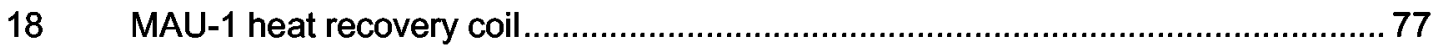

19 Heat recovery temperature sensor/thermowell ................................................. 77

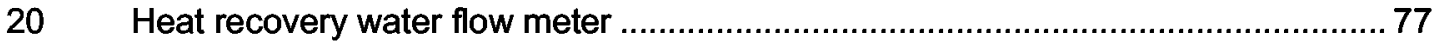

$21 \quad$ Make-up water backflow preventer .............................................................. 78

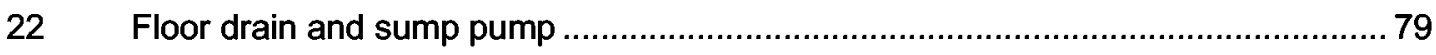

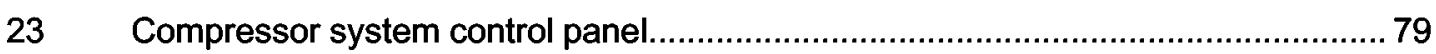

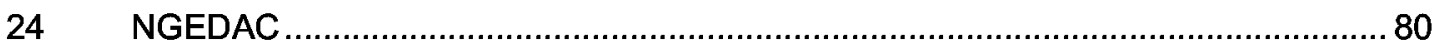

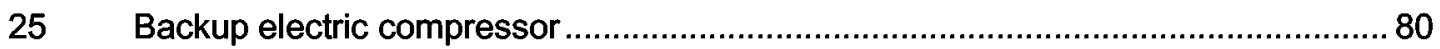

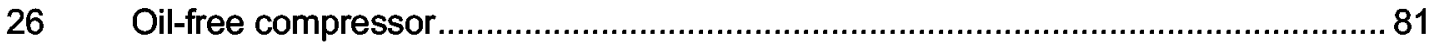

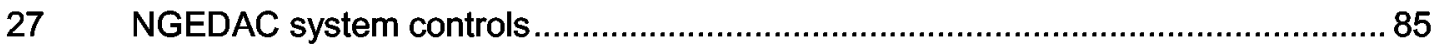

28 SIAD compressed air profile-10 September 2001 ............................................. 91

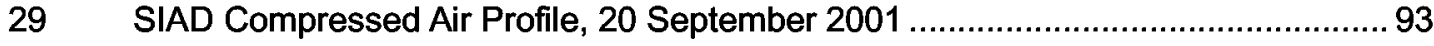




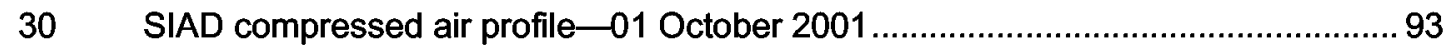

31 SIAD electric air compressor power consumption vs. air flow ...............................94

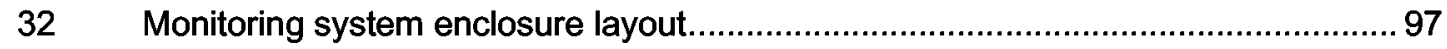

33 SIAD NGEDAC hours of operation-4/24/02 to 5/9/02 ................................... 100

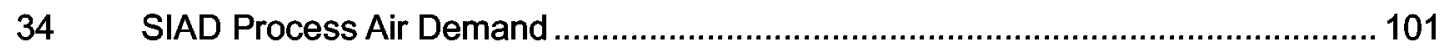

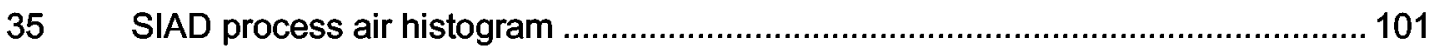

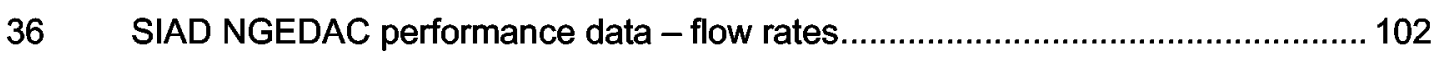

37 SIAD NGEDAC performance data - temperatures ............................................. 102

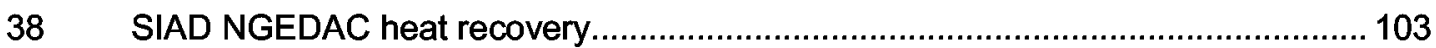

39 SIAD NGEDAC performance map (reference: Manufacturer Spec. - Gascom Memo 10/29/001 M. Bloemen to K. Frekovich)................................................. 105

40 Revised SIAD NGEDAC performance map ..................................................... 105

41 SIAD NGEDAC and electric air compressor performance maps ......................... 108

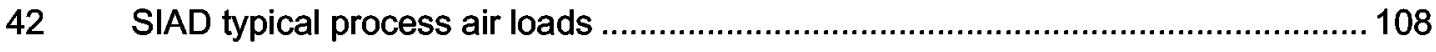

43 Annual savings sensitivity—gas/electric price changes .......................................111

44 Simple payback sensitivity—gas/electric price changes..................................... 112

$45 \quad$ Net present value sensitivity—gas/electric price changes .................................. 113

$46 \quad$ Internal rate of return sensitivity—gas/electric price changes .............................. 113

$47 \quad$ Theoretical full-load production costs for Picatinny............................................. 114

$48 \quad$ Theoretical full-load production costs for Watervliet ........................................... 115

\section{Tables}

$1 \quad$ Picatinny NGEDAC theoretical performance parameters ...................................... 31

2 Picatinny NGEDAC measured performance parameters …............................... 32

3 Picatinny electric air compressor theoretical performance measures ......................33

$4 \quad$ Picatinny annual energy costs of NGEDAC and electric air compressors................33

$5 \quad$ Watervliet NGEDAC theoretical performance parameters......................................44

$6 \quad$ Watervliet NGEDAC measured performance parameters ..................................46

$7 \quad$ Watervliet Electric air compressor theoretical performance measures..................... 47

8 Watervliet annual energy costs of NGEDAC and electric air compressors ............. 47

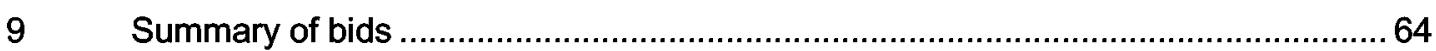

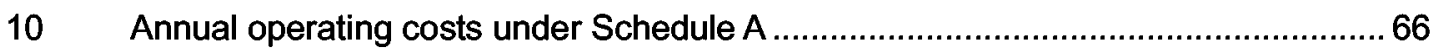

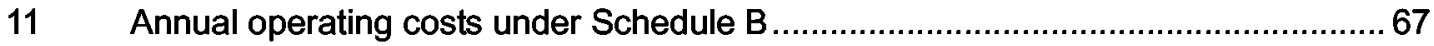

12 Economics of NGEDAC options under operating schedule A ..............................68

13 Economics of NGEDAC options under Operating Schedule B.............................68

14 Equipment serviced by electrical installation ..................................................... 71

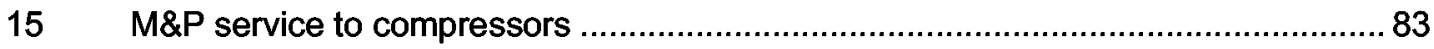




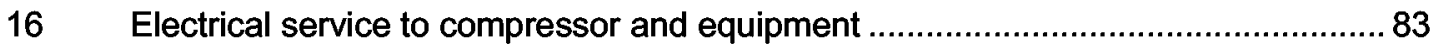

17 Equipment controlled by remote control panel..................................................... 84

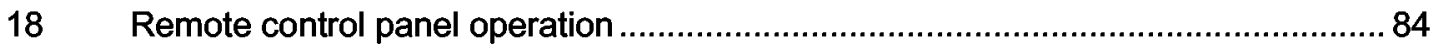

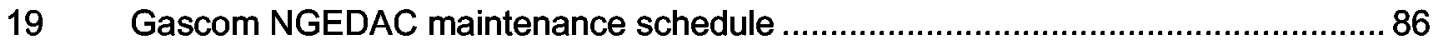

20 GD oil-free compressor maintenance schedule ............................................... 87

$21 \quad$ NGEDAC and oil-free compressor systems training at SIAD ............................... 89

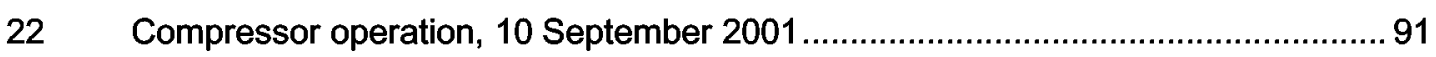

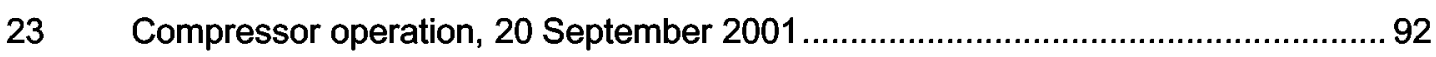

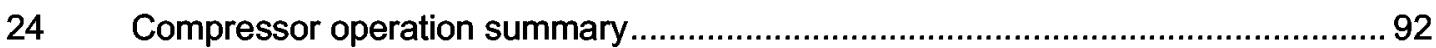

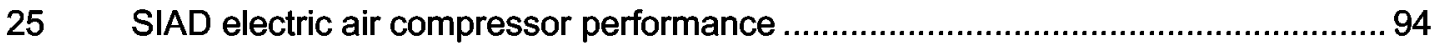

26 SIAD compressed air system temperature sensors installed ..................................96

27 SIAD monitoring system sensors wiring guide.................................................... 97

28 Sensor range, output, resistance, and scaling factors .......................................... 98

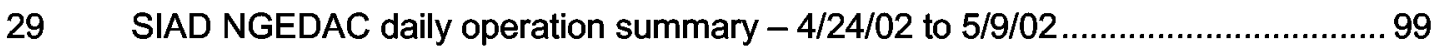

30 SIAD NGEDAC performance summary ....................................................... 104

31 NGEDAC composite performance data based on 9 May and 31 May

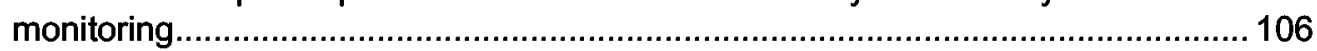

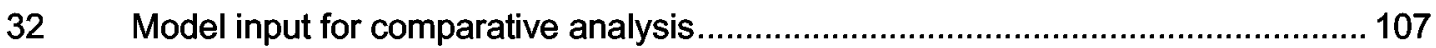

33 Energy and cost savings—NGEDAC vs. electric air compressor........................ 109

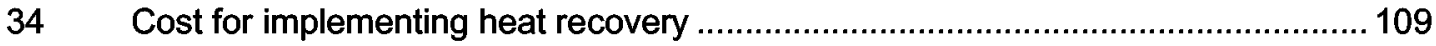

35 Economics of new/replacement vs. retrofit application .................................... 110

36 Annual savings sensitivity —gas/electric price changes .......................................111

37 Simple payback sensitivity—gas/electric price changes ..................................... 112

38 Net present value sensitivity—gas/electric price changes................................. 113

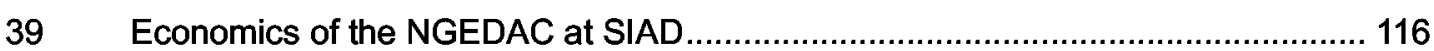





\section{Introduction}

\section{Background}

Although electricity only accounts for about one-third of the Department of Defense's (DOD's) energy consumption, it makes up two-thirds of its energy bill. Recent downsizing of DOD facilities and consolidation of facilities provides an opportunity to upgrade remaining facilities with more efficient, less polluting equipment. Oftentimes this is achieved by selecting equipment that uses electricity more economically, or that uses fuels other than electricity, e.g., natural gas-a clean-burning fuel that is abundant and readily available.

DOD industrial facilities perform a wide variety of process operations in the manufacture of munitions, weapon systems, tactical vehicles, aircraft, and naval vessels. Use of air compressors in these operations is widespread, and the variety of tools and machinery that operate on compressed air is increasing. The energy cost of operating a natural gas fueled engine-driven air compressor (NGEDAC) is usually lower than the cost of operating an electric motor driven unit. Initial capital costs of purchasing (and installing) these units are offset by differences in prevailing utility rates, efficiencies of partial load operation, reductions in peak demand, heat recovery, and by avoiding the cost of back-up generators.

Before such a change can be recommended to DOD installations, the economic benefits of a natural gas engine driven air compressor need to be demonstrated in a representative Army industrial environment. Such a demonstration would demonstrate and evaluate the technology in terms of operation and maintenance (O\&M), compressed air quality, efficiency, reliability, and air emissions-as well as in terms of economic analysis. (Favorable economics is a prime selection criterion for technology demonstration.) This would also give installation personnel a risk-free opportunity to gain operating experience with the technology.

\section{Objective}

The objectives of this work were to assess the viability of applying NGEDAC technology at 11 Army installations (identified by the Army Materiel Command 
[AMC]), and to provide a full technology demonstration at three installations. The installations (listed alphabetically, selections marked with an asterisk [“*”]) were:

- Aberdeen Proving Ground (APG), Aberdeen, MD http://www.apg.army.mil/default.htm

- Combat Equipment Group - Afloat (CEGA), Charleston, SC. http://www.globalsecurity.org/military/agency/army/ceg-afloat.htm

- Corpus Christi Army Depot (CCAD), Corpus Christi, TX http://www.ccad.army.mil/

- Lake City Army Ammunition Plant (LCAAP), Independence, MO

http://www.terc-itcorp.com/kcterc/to03/index.htm

- Lone Star Army Ammunition Plant (LSAAP), Texarkana, TX;

http://www.globalsecurity.org/military/facility/aap-lonestar.htm

- Picatinny Arsenal (PICA), * Dover, NJ

http://www.pica.army.mil/Public/

- Pine Bluff Arsenal (PBA), Pine Bluff, AK

http://www.pba.army.mil/

- Redstone Arsenal (RSA), Huntsville, AL

http://www.redstone.army.mil/

- Rock Island Arsenal (RIA), Rock Island, IL

http://www.ria.army.mil/

- Sierra Army Depot (SIAD), Herlong, CA.

http://www.sierra.army.mil/index.html

- Watervliet Arsenal (WVA), * Watervliet, NY

http://www.wva.army.mil/

\section{Approach}

This study included the following tasks:

1. Conduct Site Evaluations and Select Demonstration Sites. Eleven army industrial sites were identified as possible candidates to host the NGEDAC demonstration. A 1-day site survey at each installation was performed for the purposes of identifying opportunities to reduce compressed air operating expenses and to determine its suitability as host site. The site survey involved:

a. collecting data on the performance of the major compressed air systems

b. estimating the cost of operating the systems based on the performance data and utility rate data, and maintenance expenses

c. identifying specific measures to reduce energy used by the compressed air systems and determining the magnitude of the possible operating cost savings, as well as associated implementation costs 
d. determining the economics of an NGEDAC, assuming the application was suitable from a technical stand-point (e.g., sufficiently large loads and hours of operation, access to natural gas supply, etc.)

e. selection of the best three candidates for the NGEDAC demonstration from among the eleven sites.

2. Develop Conceptual Design. Schematics and specifications establishing the basic requirements for the NGEDAC (e.g., equipment layout, compressed air design capacity, heat recovery interface, etc.) were developed. In addition, the task involved preparing a plan for determining the performance of the existing electric motor driven air compressor and the NGEDAC. A budgetary cost estimate for the NGEDAC was also developed.

3. Develop Engineering Design. Detailed engineering drawings and specifications for the NGEDAC were prepared with critical design reviews held at the 65 percent design and 100 percent design stage.

4. Baseline Performance Testing. The existing electric motor driven air compressors were monitored to determine their operational efficiencies and typical operating characteristics. This involves measurement of compressor inlet air temperatures, supply air pressures and flow rates, and electric power use, and documenting operating schedules over a 1-week period, to establish a baseline against which the NGEDAC performance and economics could be compared.

5. Equipment Purchase, Installation, Start-Up, and Training. The NGEDAC is prepurchased based on a competitive bid process, with the conceptual design package serving as the basis for the quotes. A 2-year maintenance contract was specified as part of the bid package. The installation contractor was also selected through a competitive bid process with the engineering design documents providing the basis for the contractors' quotes. System start-up was performed by the NGEDAC supplier. Commissioning/acceptance testing involved operating the equipment at various load conditions and measuring or observing the performance of key equipment - the NGEDAC, the heat recovery subsystem, air intake, and exhaust systems, controls, etc. The NGEDAC supplier provided training in basic start-up and shutdown sequencing and maintenance.

6. NGEDAC Evaluation. The NGEDAC performance was monitored to determine its operational efficiency and typical operating characteristics. This involved measurement of the inlet air temperatures, supply air pressures and flow rates, and natural gas use as well as operating schedules over a 1-week period. Comparable data on the electric motor driven air compressor was also obtained to supplement the information collected earlier under task 4. A comparison of the annual operating costs of the NGEDAC relative to the electric motor driven air compressor was obtained by extrapolating the performance data and combining it with utility rate information (purchased electricity and natural gas) and maintenance cost estimates.

7. Prepare Technical Documentation. 


\section{Scope}

This study involved the provision of turnkey services for the design, installation, and evaluation of a natural gas engine driven air compressor, as well as the identification of other opportunities for reducing compressed air energy operating costs. The procedures used in implementing the project-from site identification through performance monitoring-are broadly applicable to other DOD industrial facilities.

\section{Mode of Technology Transfer}

The information presented in this report will be furnished directly to the sponsoring organization and the 11 Army bases studied, and to the U.S. Army, Installation Management Agency Headquarters and Regional Offices:

- Installation Management Agency

http://www.ima.army.mil/index.asp

- Installation Management Agency, Northwest Region

http://www.ima.army.mil/northwest/index.asp

- Installation Management Agency, Northeast Region

http://www.ima.army.mil/northeast/index.asp

- Installation Management Agency, Southwest Region

http://www.ima.army.mil/southwest/index.asp

- Installation Management Agency, Southeast Region

http://www.ima.army.mil/southeast/index.asp

- Installation Management Agency, Pacific Region

http://www.ima.army.mil/pacific/index.asp

- Installation Management Agency, European Region

http://www.ima.army.mil/europe/index.asp

- Installation Management Agency, Korea Region

http://www.ima.army.mil/korea/index.asp

It will also be published via the World Wide Web (WWW) at URL:

http://www.cecer.army.mil/

Also, a technical paper documenting the demonstration of NGEDAC at PICA and WVA was presented at the Industrial Energy Technology Conference in April 2002. It was published in the Conference Proceedings and also can be viewed via the following URL: 
Development of this web site was co-funded by Industrial Center, Inc. and USACERL. It contains relevant information on NGEDAC applications and is being updated periodically by the Industrial Center. Operating performance of the NGEDAC at Army sites will continuously be monitored and the results will be made available via the web updates. Facility engineers and planners shall take advantage of this web information in considering potential future NGEDAC project screening and implementation.

\section{Units of Weight and Measure}

U.S. standard units of measure are used throughout this report. A table of conversion factors for Standard International (SI) units is provided below.

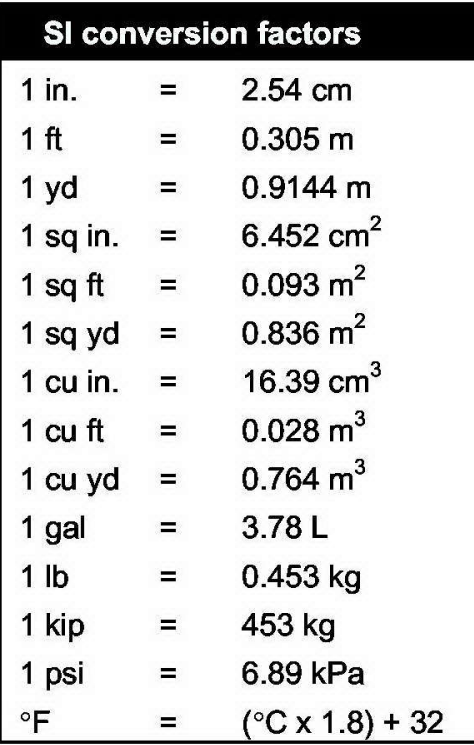




\section{Site Assessments}

With the first year's funding, the Project Team-consisting researchers from the U.S. Army Engineer Research and Development Center, Construction Engineering Research Laboratory (ERDC/CERL), Technology \& Management Services, Inc., and XENERGY, Inc.-conducted six site assessments (Level I Audits) to select two sites for demonstration at six candidate locations:

- Picatinny Arsenal (PICA), NJ

- Watervliet Arsenal (WVA), NY*

- Corpus Christi Army Depot (CCAD), TX

- Lone Star Army Ammunition Plant (LSAAP), TX

- Pine Bluff Arsenal (PBA), AR

- Combat Equipment Group-Afloat (CEGA), SC.

Evaluation results are highlighted below.

\section{Picatinny Arsenal}

The Picatinny Arsenal site showed favorable economics and presented a number of other positive aspects that help make it a good demonstration site candidate. Gas supply was readily accessible. Physical space was available and plant modifications would be minimal. Experience and confidence gained by Picatinny staff and contractors in developing and operating the existing 2.2 megawatts-electric (MWe) natural gas-fueled cogeneration system were a significant plus and could help reduce cost estimates for maintenance contracts for the NGEDAC system.

\footnotetext{
* Detailed evaluation results for PICA and WVA can be found in a published USACERL Technical Report, ERDC/CERL TR-01-65, Applications Guide for Compressed Air Systems. Appendices A\&B. A separate report covering the results for the rest of the bases is being prepared.
} 


\section{Watervliet Arsenal}

The Watervliet Arsenal site demonstrated favorable economic conditions for implementation of a gas engine driven system. Such a system was estimated to cost $\$ 210,000$ annually in fuel expense and save $\$ 98,000$. Maintenance costs for the NGEDAC technology are $\$ 15,000$ higher annually based on a 2-year maintenance contract. The resulting net operating cost of a NGEDAC system was estimated at $\$ 83,000$ less than the current electric system, when the pre-existing centrifugal compressor is operating.

\section{Corpus Christi Army Depot}

The Corpus Christi Army Depot site had a number of positive aspects. Gas, electric, and water supplies are readily accessible. However, logistically, the site presents difficulties in installing a NGEDAC due to an ongoing utility decentralization work. First, the design phase for the proposed compressed air decentralization plan needed to be moved forward enough for the NGEDAC project to be designed at the same time. Also, the decentralization plan needed to pick up certain costs associated with the NGEDAC project such as the cooling tower and other items that would only be constructed during the decentralization plan that would be needed after the NGEDAC Project is complete, e.g., the heat recovery system with the NGEDAC unit. Second, the NGEDAC needs to be assigned to play a critical role in the decentralization plan and, as such, its accumulative savings do not need to be measured against the entire capital cost of the NGEDAC unit. Third, the NGEDAC needed to be able to claim the full theoretical savings of its peak shaving capability, which will be reflected in the electric bill paid by the Corpus Christi Naval Air Station, but not necessarily reflected in the electric bill paid by its tenant, the Corpus Christi Army Depot.

\section{Lone Star Army Ammunition Plant}

The compressed air system at Lone Star Army Ammunition Plant is a very efficient and correctly applied system. The compressors have been recently serviced and the entire drying system upgraded. The system is well maintained. The plant enjoys very low electric rates, which average $\$ 0.045$ per $\mathrm{kWh}$-about half of some of the other sites that have been considered. High system efficiency and low electric rates combine to give Lone Star one of the lowest cost structures among all the compressed air systems that were reviewed. The Lone Star site was not considered as a viable NGEDAC site, unless prevailing operating and economic conditions change. 


\section{Pine Bluff Arsenal}

Pine Bluff Arsenal had a number of positive aspects. Gas supply is readily accessible. However, Pine Bluff demonstrates only marginally favorable economic conditions for implementation of a gas engine driven system to replace one of the existing electric units.

\section{Combat Equipment Group-Afloat}

The preliminary assessment concludes that the Combat Equipment GroupAfloat (CEGA) is not a good candidate for additional consideration. The current system already consists of well-applied electric compressors and a well-managed distribution system. The distribution system has recently undergone a systematic leak repair program and is monitored effectively by a Johnson Controls energy system. In addition, the gas rates currently charged to the CEGA are disproportionately high relative to the electric rates being charged.

With the second year's funding, USACERL and SAIC conducted five site surveys and selected one for demonstration. The following Army industrial installations were studied:

- Aberdeen Proving Ground (APG) - Aberdeen, MD

- Lake City Army Ammunition Plant (LCAAP) - Independence, MO

- Redstone Arsenal (RSA) - Huntsville, AL

- Rock Island Arsenal (RIA) - Rock Island, IL

- Sierra Army Depot (SIAD) - Herlong, CA

The following section summarize the five surveys.

\section{Aberdeen Proving Ground (APG)}

Several hundred small compressors (e.g., under $20 \mathrm{hp}$ capacity each) distributed across the base provide most of the facility's compressed air. Many buildings on the Aberdeen Proving Ground and the adjacent facility, the Edgewood Arsenal are not connected to the base natural gas distribution system. Since the objective of the survey was to focus on larger central compressed air systems that were in reasonable proximity to a natural gas line, this limited the survey to a few buildings. These were Bldgs $345,4600,338,525$, and 315 . Of these buildings, 345 (boiler house), 315 (machine shop), and 525 (tank maintenance facility) were examined most closely. 
Estimated energy operating costs for the 399 air compressors at APG were $\$ 629,509$ based on $10,853,611 \mathrm{kWh}$ of energy use per year. This was based on an average price of electricity of $\$ 0.058 / \mathrm{kWh}$. Reducing leaks appeared to be the greatest overall opportunity for reducing energy use and operating costs. APG could save approximately $\$ 94,426$, based on a 1.628 million $\mathrm{kWh}$ reduction in electricity use.

Aberdeen Proving Ground did not appear to be a strong candidate for a natural gas engine driven air compressor demonstration due to the relatively small capacity of the compressors that are near natural gas lines, the low hours of operation and loading, limited heat recovery opportunity, and unfavorable economics.

\section{Lake City Army Ammunition Plant (LCAAP)}

The compressed air survey focused on Bldgs 1 and 3, which are the largest users of compressed air. Generating compressed air for Bldgs 1 and 3 costs $\$ 474,000$ per year, or nearly 25 percent of LCAAP's electricity expenditures. This was based on an average electricity cost of $\$ 0.049 / \mathrm{kWh}$. Bldg 1 has eight 500-hp Gardner Denver compressors, each with a design air supply capacity of 2500 standard cu ft per minute (scfm) at 100 psig. Typically, no more than four of these units are in operation, since the maximum compressed air demand was on the order of $9900 \mathrm{scfm}$. Bldg 3 has two 200- hp Gardner Denver compressors, each with a design air supply capacity of $1000 \mathrm{scfm}$ at $100 \mathrm{psig}$. Typical compressed air demand was $1600 \mathrm{scfm}$ total. The units are fairly recent vintage (1990s) and appear to be in reasonable operating condition. The compressors have sequential controllers to enable efficient distribution of the compressed air loads among the compressors. No operational problems were noted with the compressors or ancillary equipment.

LCAAP has an active leak detection program that has helped maintain compressed air leaks to approximately 15 percent of the total demand-a relatively low level of leakage. The air pressure provided by the system matches the load requirements well, consequently, no opportunities to reduce compressor operating pressures were noted. The most significant opportunity for cost savings from the compressed air system is from recovering waste heat from the compressor oil coolers and the compressed air after coolers in Bldg 1. Currently, waste heat is only being recovered from 2 of the units (oil cooler heat recovery). This heat would be used for process water heating within the building, offsetting natural gas fuel purchases for the boiler. The estimated annual savings was $\$ 32,437$ and the associated fuel energy savings was 5,612 MMBtu. 
A natural gas engine driven air compressor can readily be accommodated at Lake City Army Ammunition Plant, with possible applications in either Bldg 1 or 3. While the current economics favor a Bldg 1 application, Bldg 3 has a potentially greater need for additional compressed air capacity (currently two portable diesel engine driven air compressors are being operated to meet specialized loads), and has greater heat recovery opportunities. Furthermore, the NGEDAC can be sited next to the natural gas station immediately outside the building, whereas a location serving Bldg 1 would require a more significant gas piping run (100 ft). The unit would be housed in its own heated weatherproof enclosure to protect it from the elements. The NGEDAC supply air would be tied into the existing supply system from Bldg 3, and make use of the existing receiver and $2000 \mathrm{scfm}$ air dryer. The NGEDAC could potentially: (1) meet the full load supplied by the existing electric motor driven air compressors, or (2) be operated in combination with one or both of these units to meet load growth. In particular, the NGEDAC could be used in place of the two portable diesel engine driven air compressors. Waste heat from the NGEDAC would be recovered and used for process water heating applications.

\section{Redstone Arsenal (RSA)}

Compressed air requirements vary across RSA depending upon application and virtually each building where compressed air is used has its own dedicated system. Three compressed air end-use systems were selected for the site survey based on total installed horsepower, annual hours of operation, proximity to a natural gas supply, and accessibility due to security requirements. The systems serve Bldgs 5436 (calibration laboratory facility), 7159 (rocket testing/fuel grinding), and 3634 (motor pool vehicle maintenance shop. Each building is served by a primary compressor and has a back-up compressor(s). Primary compressor sizes are $25 \mathrm{hp}, 150 \mathrm{hp}$, and $50 \mathrm{hp}$ for Bldgs 5436, 7159, and 3634, respectively. The compressed air survey identified several compressed air system operational cost cutting opportunities.

RSA was found not to be a suitable site for installation of an NGEDAC for the following reasons:

1. Small compressor size

2. Short hours of operation, each compressor system surveyed operated 2,000 hours/year or less

3. No heat recovery applications were discovered. 


\section{Rock Island Arsenal (RIA)}

The compressed air survey focused on Bldgs 220 and 222 that are the largest users of compressed air and house the main compressors. It is estimated that the compressed air costs RIA about $\$ 154,326$ based on $3,486,960 \mathrm{kWh}$ of energy use per year. This was based on an average electricity cost of $\$ 0.044 / \mathrm{kwh}$. Bldg 220 has 5 compressors capable of providing $14,000 \mathrm{scfm}$ of air at $100 \mathrm{psig}$. However, the $4200 \mathrm{scfm}$ Ingersoll-Rand reciprocating compressor and the $3700 \mathrm{scfm}$ Worthington reciprocating compressor alternate in providing most of the facility's demand $-3000 \mathrm{scfm}$ during normal production hours and $1800 \mathrm{scfm}$ at all other times. These units are 1940s and 1950s vintage, but are capable of efficient operation. No operational problems were noted with the main compressors or ancillary equipment.

RIA does not have an active leak detection program, and could benefit from such an effort. It was estimated that leak reductions could save the installation $\$ 26,340$ annually, based on $360 \mathrm{scfm}$ of reduction in losses, and corresponding energy savings of $600,686 \mathrm{kWh}$. Additional cost cutting/energy savings opportunities identified include: (1) operating the most efficient compressor(s) rather than rotating use of the many compressors on hand - annual savings of $\$ 7,297$ and $165,840 \mathrm{kWh}$, and (2) heat recovery from compressor inter and after coolers for space heating-annual savings of $\$ 14,853$ in natural gas fuel expenses. Implementation of item 1 could also reduce operator time spent on the various units, freeing up this individual for implementing the leak detection program.

Based on an electricity rate of $\$ 0.049 / \mathrm{kWh}$, which includes demand and energy charges and a natural gas rate of $\$ 4.71 / \mathrm{MBtu}$, RIA is a marginal site (near break-even) for installation of an NGEDAC, with the most favorable location just outside Bldg 222. A $400 \mathrm{hp}, 1800 \mathrm{scfm}$ NGEDAC unit was evaluated in terms of energy performance and economics for the intended application. The unit would be operated at design capacity during the utility on-peak period - about 3,942 hours per year. This operating mode was chosen because it enables the NGEDAC to reduce electricity use during the most expensive periods.

\section{Sierra Army Depot (SIAD)}

The compressed air survey focused on the feasibility of installing a $125 \mathrm{hp}, 600$ scfm natural gas engine driven air compressor as a direct replacement for the existing electric motor driven air compressor of the same capacity. The existing unit is housed in Bldg 210 but serves as the central compressed air source for two other Bldgs (208 and 209). Adequate space exists within this building for 
the NGEDAC. Natural gas is available and heat recovery for space heating appears promising. The net annual operating cost savings are estimated to be $\$ 16,373$ based on an electricity rate of $\$ 0.145 / \mathrm{kWh}$ average - includes demand at $\$ 7 / \mathrm{kW}$ and energy charges at $\$ 0.105 / \mathrm{kWh}(2 / 6 / 01$ rate) and a natural gas rate of \$7.28/MBtu (average for April 2000 - March 2001). Previous compressed air system survey identified six other opportunities for reducing energy and operating costs associated with the system (Lin, et al, Compressed Air System Survey at Sierra Army Depot, ERED/CERL TR-00-37, November 2000). These six opportunities (other than the NGEDAC) included:

- repair compressed air leaks

- change the air compressor control to low demand mode

- disconnect the air receiver from the oil/water separator

- duct outside air into the air compressor room

- install sensor-type valves on the purifier pre-filters

- replace the timer-type drain valves with sensor-type valves.

Collectively, these six opportunities represented an annual cost savings of $\$ 15,541$ in electricity costs, an energy savings of $181,409 \mathrm{kWh}$, and a demand reduction of $49.9 \mathrm{~kW}$. Given the recent price increases in electricity, these savings opportunities are increasingly attractive to SIAD.

\section{Demonstration Site Selection}

While most of the sites could accommodate the NGEDAC, Picatinny and Watervliet represented the best sites in terms of economics, access, and ease of installation. CCAD, PBA, LSAAP, CEGA, APG, RIA and RSA were found not to be suitable demonstration sites due to marginal or poor economics. Both SIAD and LCAAP were found to be suitable on the basis of the application and economics. Since LCAAP had a much larger compressed air requirement than SIAD (e.g., $1600-10,000 \mathrm{cfm}$ vs. $500 \mathrm{cfm}$ ), longer hours of operation (6100 vs. 2080 hours per year), and had a large year-round load that was suitable for demonstrating NGEDAC heat recovery, it was initially determined to be the better candidate.

A follow-up site visit to LCAAP on 21 June 2001 to confirm technical information, as well as the interest of the base personnel in hosting the NGEDAC demonstration, indicated the site was a solid candidate. However, base personnel preferred that the NGEDAC unit be installed in Bldg 3, rather than Bldg 1 due to the need for additional capacity in that building. Two diesel engine driven air compressors are currently being used to provide this additional capacity. 
The savings for the diesel case were far greater due to the displacement of high priced diesel fuel $(\$ 37,518$ in savings relative to the diesel versus $\$ 11,061$ relative to the electric motor driven air compressor). In comparison, the annual operating cost savings for an NGEDAC at SIAD were estimated to be $\$ 16,373$. Therefore, the initial decision was to select LCAAP as the demonstration site. However, after considering that LCAAP was a contractor operated government facility, and that the NGEDAC savings would flow to the private operator rather than the government, it was decided by the HQAMC staff that SIAD would be the preferred site.

SIAD had the advantage of being a government owned and operated installation, which meant the operating cost savings would be passed on to the government. SIAD agreed to be the host installation with the provision that this project helps underwriting the costs of an electric motor driven oil-free air compressor to serve breathing air loads. To comply with the Army Respiratory Protection Program requirements, an oil-less compressor is needed for breathing air generation at SIAD. Once the demonstration sites were selected, the Project Team developed the conceptual design for each site. The next step in the design phase was to prepare the 65 Percent Design Package report followed by the 100 Design Package report, which is essentially the "as-built" design. The highlights of that report, and most importantly, the as-built design are discussed below for each site. 


\section{Picatinny NGEDAC Demonstration}

Picatinny Arsenal met all of the criteria for the demonstration. Further, the site was relatively close to the other site selected, Watervliet Arsenal, NY; the close proximity of these sites allowed many of the same Project Team personnel to work at both sites and reduced travel costs.

The NGEDAC unit is part of a gas/electric hybrid system capable of delivering 100 percent of the base load requirements with the NGEDAC as the primary air compressor. Picatinny will use the NGEDAC unit as its primary compressed air delivery system, with the two pre-existing electrically driven Ingersoll-Rand units kept in reserve service. The electric compressors will be maintained for full demand capability so that no interruptions to the compressed air service will be experienced during installation, maintenance, or unplanned downtimes of the NGEDAC system. Additionally, by maintaining 100 percent load capability with the electric compressor system, fuel-switching options are available if economics change or interruptible options become economically feasible.

The initial budget costing for this project is comprised of two main bids. Equipment manufacturer, Dearing Compressor, provided the first bid. Dearing Compressor will be providing the entire compressor package unit which includes: (1) One Dearing Ultra-Air Model GRS-125LA Natural Gas Engine Driven, Air Cooled, Rotary Screw Air compressor; (2) A Gardner Denver rotary screw air end with inlet valve; (3) One Caterpillar G3306NA natural gas engine rated at 145 HP at 1600 RPM, with 24-volt starter, altometer, a battery set and gas shut off valve; (4) An Engine Jacket water radiator powered by 7.5 Hp, TEFC fan motor with NEMA 12 460-volt combination starter; and (5) One hospital type exhaust muffler with stainless steel flexible exhaust connector.

Scales Air Compressor, who was responsible for installing the new compressor, all the auxiliary equipment, and making all the necessary tie-ins, provided the second bid that comprised budget costing.

The Picatinny site will require additional custom work for such items as a roll up door, a possible separate panel box, and two 6-in. shut off valves for compressor lines. 
The size of the proposed new compressor is too large to fit into any existing access opening at the installation location in the building. The project team concluded that a small exterior wall area would have to be removed to get the unit in place. An exterior wall area that had been removed before by the arsenal for the removal of hydraulic equipment was chosen. An area 8 by $8 \mathrm{ft}$ was removed and an overhead, roll up door was framed in and installed for future access to this area.

A description of the installed equipment, evaluation of the NGEDAC system performance, demand-side recommendations, and project schedule and costs are discussed below.

\section{Pre-Existing Equipment}

The pre-existing Picatinny compressed air system consisted of two $18 \frac{1}{2}$ x $11 \frac{1 / 2}{2}$ 81/2-in. stroke, double acting, reciprocating-type Ingersoll Rand compressors. Each unit is rated at $200 \mathrm{bhp}$ (1,130 acfm at a design pressure of 100 to $110 \mathrm{psig})$ and has five-step unloading capability. Each compressor requires approximately 127 kilowatts of power to deliver 925 acfm for a specific power rating of about $7 \mathrm{cfm}$ per $\mathrm{kW}$. Each unit is capable of delivering the required base load of approximately $925 \mathrm{acfm}$ at $80 \mathrm{psig}$. The existing control strategy uses one unit while holding one in reserve, switching periodically to maintain consistent operating hours between the two. Unit \#1 is located in the southeast corner of the first level of Bldg 506 and unit \#2 is northwest of unit \#1 in an adjacent room. The floor in the room where Unit \#1 is located has a load bearing, concrete floor assumed to be of sufficient strength for the location of the proposed NGEDAC unit. Base personnel have stated that very heavy hydraulic pumps were removed from this area, evidenced by markings in the floor. No details of the floor design are available.

Air delivered from the compressors is passed through an aftercooler for initial moisture removal but has no other drying capabilities. Two large receivers, one for each compressor, are located outside to the South of Bldg 506 and they are over 30 years old. Compressed air is delivered to the bottom of the receivers and exits at the top.

Near the start of the project, flow and pressure were measured for 24 hours to document "as-found" conditions. The data indicated an average $800 \mathrm{scfm}$ (900 acfm) of continuous demand over the 24 hours, which includes both production and nonproduction hours at Picatinny because the arsenal is essentially a oneshift operation. The pressure held steady at 79 to 80 psig during the entire test. 


\section{NGEDAC Equipment}

A Dearing Ultra Air Model GSR-125LA air-cooled natural gas engine and rotary screw compressor system (Figure 1) was determined to be the best match for the gas/electric hybrid compressed air system. The compressor is designed to supply 80-psig discharge pressure to the plant with a maximum discharge capacity for the unit of $610 \mathrm{cfm}$. The prime mover is a Caterpillar G3306NA natural gas engine with a rating of $116 \mathrm{hp}$ at 1,800 rpm. The Caterpillar engine also has a 24volt starter, altometer, a battery set, and gas shutoff valve. A model H60-10 heat exchanger manufactured by R\&R Engineering is located on the east exterior wall of Bldg 506. The heat exchanger cools engine oil, the engine jacketcooling medium, and acts as the aftercooler for compressed air using a 5-hp fan and damper system. The unit has lubrication system heaters and a hospital type exhaust muffler with stainless steel flexible exhaust connector and a catalytic converter. The required natural gas pressure for the unit is $2-5$ psig. The natural gas engine is equipped with a Miratech Model MEC 2001 Air Fuel Ratio Controller for emissions control. The controller automatically maintains the optimal fuel mixture to achieve emissions compliance without operator supervision. The system also optimizes catalyst management and provides system diagnostics. The turnkey installation of the system was provided by the equipment vendor Scales Air Compressor under the direction of Mr. Ernie Wichert and supervised by XENERGY.

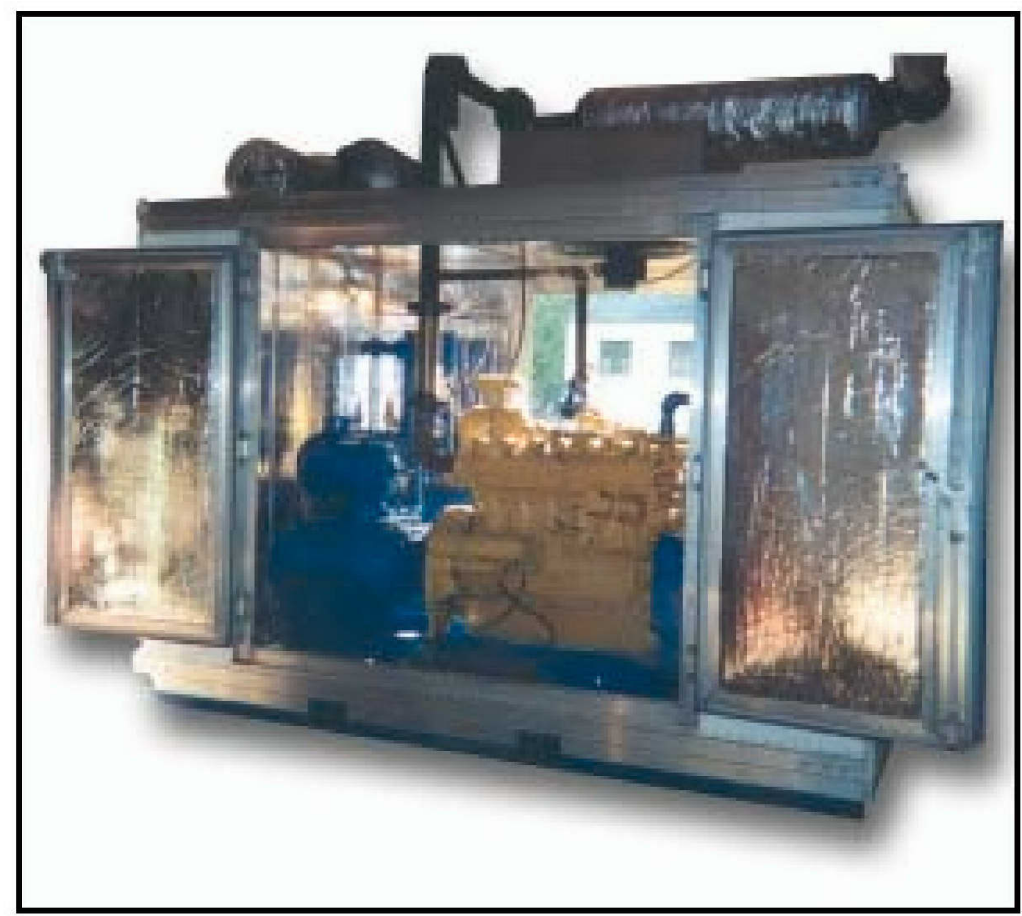

Figure 1. Dearing Ultra Air Model GSR-125LA NGEDAC installed at Picatinny Arsenal 
The compressor component is a single-stage, positive displacement Gardner Denver Model SSQ Rotary Gas Compressor. Figure 1 shows the compressor and natural gas engine in a weatherproof, sound attenuated acoustic enclosure with multiple access doors and ventilation fan. The enclosure is approximately 94 in. wide by $132 \mathrm{in.} \mathrm{long} \mathrm{by} 95 \mathrm{in}$. high (not including the muffler).

The chosen location to install the new natural gas engine driven compressor is in the powerhouse located in Bldg 506. This location was chosen because of its close proximity to the main natural gas meter, a large open floor area to place the new unit, relatively easy tie-ins to the existing compressed air lines and the use of the existing compressor \# 1 electrical panel. The compressor unit was located directly to the northeast of the existing electric compressor. The two compressors were approximately $10 \mathrm{ft}$ apart. The compressed air piping for the NGEDAC system was tied in to the pre-existing 6-in. line and fed into the main header system. Manual shutoff valves were installed on the existing piping and the new piping.

CAD drawings were created to represent the NGEDAC unit and auxiliary equipment plans and specifications, construction details; engine exhaust location; glycol cooler, pump set and piping location, specifications and construction details; compressed air and gas piping location, specifications, and construction details; and electrical feeds, circuit location, specifications, and construction details.

The following is a description of how the gas piping, electric, compressed air piping, and exhaust air piping were integrated into the new compressor.

\section{Integration with Gas and Electric Systems}

\section{Natural Gas System}

The incoming natural gas feed for the site is located in a fenced area on the northeast side of the property. The local gas distribution company, New Jersey Natural Gas (NJNG), agreed to install a new meter and regulator, and to run piping to an area directly outside the fenced gas meter area. A representative from NJNG, Mr. Graig Swaylik, is the primary contact to coordinate the installation of the new gas meter on site. The gas meter installation was completed 11 October 2001.

The gas company run piping from the meter in the fenced area to a predetermined location directly outside the fence area. The new piping is a 3-in. diame- 
ter line with a 2 psi gas pressure. The line was run to Bldg 506 in an existing exterior underground tunnel, which presently is how the other two gas lines are run into the building. Scales Air Compressor connected to and run a new gas line from the NJNG stub to the new compressor. Scales Air Compressor was responsible for all materials and labor to install the new natural gas compressor.

Gas service to supply the NGEDAC unit is available under several rates: firm service, interruptible service, and a new "Distributed Gas" (DG) rate. The DG rate is a transportation rate with a curtailable option under which Picatinny would be responsible to purchase commodity through the same Defense Energy Support Center (DESC) supply programs that they currently use. Picatinny was paying about $\$ 4.20$ per decatherm under firm service tariffs. Service under the DG rate is expected to be less. The DG rate availability is pending final approval; the tariff is not available as yet.

No charge was incurred by the project for the gas meter and data logger required to take service under the DG rate. NJNG's estimated direct cost for the meter is $\$ 3,833$ and includes the data logger that will provide capability to remotely read the meter via a phone line connection. Picatinny Arsenal personnel was responsible for negotiating with NJNG for firm gas service with a curtailment option.

\section{Electric System}

The existing electrical panel servicing compressor \#1 was originally identified to supply the electricity for the new compressor unit. The existing compressor is an electric unit, which indicated a more than adequate power source for the new gas compressor unit. The existing compressor panel was used for both the older existing compressor unit and the new gas unit. The logic behind using the same panel box and power supply is that only one unit will ever need to be running at any given time.

Picatinny and Scales subsequently checked the loading of circuit breakers in this and other available electrical panels. Circuit breakers E-7 and E-8 each rated at 225 amps from Panel E 480 VAC with power coming from the $750 \mathrm{KVA}$, 2400/480V transformer. Circuit breaker E-8 is being used for power to welding machines with about $200 \mathrm{Amps}$ load. Circuit breaker E-7 is being used for power to 25 HP Compressor No. 4 with a full load of 32 Amps. The E-7 circuit breaker and power cable for Compressor No. 4 breaker/switch were identified to be used for additional load. 


\section{Integration with Existing Compressed Air Piping}

The compressed air piping that is being supplied from the existing electric unit is a prime area for the project team to tie-into the main compressed air loop. The existing piping has a diameter of approximately 6 in. and is fed to a main header located in the middle of the building. The project team proposed to tie-into the existing 6-in. line and use that existing piping to feed into the main header system. Therefore, the existing piping and the new pipe needs to have a manual shut off valve installed on both pipes. The valve is shut off on the existing system when the new gas unit is working.

\section{Exhaust System Placement}

The project team and Picatinny personnel decided to run a 4-in. exhaust pipe outside through the North wall. This location was chosen by arsenal personnel to reduce the noise level to residents to the East of the plant. The new compressor system incorporated a hospital type muffler with a stainless steel flexible exhaust connector.

\section{Spill Containment}

Due to the proximity of the new NGEDAC unit to a floor drain, containment was required as per spill prevention regulations (40 CFR 112.7) which require a secondary means of containment for the largest single compartment, engine oil and coolant, of the system plus sufficient freeboard to allow for precipitation. The Project Team, Picatinny personnel and Scales have developed and installed a stainless steel pan containment system for both the inside NGEDAC unit and the outside air cooler.

The project team ordered the new compressor, which took approximately 10 to 14 weeks to be shipped. Prior to shipment of the unit, Mr. Ernie Wichert started to prepare the site location of the new compressor. The installer removed the exterior wall and installed the roll up door to allow the necessary access for the equipment installation, run the required gas piping to the new compressor area, tie-in to the existing compressor line, install shut off valves, and run the preliminary electric and exhaust piping to the proposed area.

The complete operation and maintenance service manuals for this equipment, along with the cooling system, gas meter, and electric meter manuals were combined into one manual and delivered to the site during the onsite system training sessions. Further, a 2-year maintenance agreement was included as part of the project. 


\section{Permitting and Emissions}

The environmental emission levels of the NGEDAC are based on limits of 0.70 $\mathrm{gm} / \mathrm{bhp} / \mathrm{hr}$ for oxides of nitrogen and $0.48 \mathrm{gm} / \mathrm{bhp} / \mathrm{hr}$ for carbon monoxide. The emission limits of the recommended NGEDAC equipment are:

- Oxides of Nitrogen $\quad 0.18 \mathrm{lb} / 10^{6} \mathrm{Btu}$

- Carbon Monoxide $0.13 \mathrm{lb} / 10^{6} \mathrm{Btu}$

- Total Hydrocarbons $0.37 \mathrm{lb} / 10^{6} \mathrm{Btu}$

- Non-Methane Hydrocarbons $0.07 \mathrm{lb} / 10^{6} \mathrm{Btu}$

- Sulfur Dioxide $\quad<0.05 \mathrm{lb} / 10^{6} \mathrm{Btu}$

- Total Suspended Particles $<0.05 \mathrm{lb} / 10^{6} \mathrm{Btu}$

- Particulate Matter (PM10) $<0.05 \mathrm{lb} / 10^{6} \mathrm{Btu}$.

Mr. Bob Smith, the Environmental Coordinator at Picatinny, is conducting the environmental permitting. Mr. Smith was responsible for all permit applications with regards to this project. The arsenal has indicated that they would inform the project team on possible environmental concerns for this project. During the initial correspondence with Mr. Smith he indicated that the only possible area of concern is that the base may require a permit application if the new compressor unit exceeds a $1,000,000 \mathrm{Btu} / \mathrm{hr}$ rating. The project team reduced the original equipment design capacity by 10 percent to meet this criterion. The specified unit operates at $116 \mathrm{BHP}$ at full load capacity of $610 \mathrm{cfm}$. The resulting fuel consumption of $8,436 \mathrm{Btu} / \mathrm{hp}$-hr results in a full load heat rating of 978,460 $\mathrm{Btu} / \mathrm{hr}$, which is slightly below the regulatory limit. The equipment nameplate reflects this $978,460 \mathrm{Btu} / \mathrm{hr}$ rating.

\section{Compressor Efficiency and Cost Analysis Results for Picatinny}

After commissioning, the NGEDAC performance was measured. These measurements were made to:

- verify the performance of the gas unit against the published specifications of the unit

- establish a benchmark for the gas unit efficiency under various loads

- update the comparison of gas consumption and cost with the electric units

- verify energy savings and flow reduction associated with the demand-side projects.

\section{Theoretical Performance}

Table 1 shows the theoretical performance parameters provided with the NGEDAC equipment specifications for various loading conditions. At full load, the unit produces $610 \mathrm{cfm}$ and uses 978,460 Btu per hour. At about two-thirds load, the unit operates nearly as efficiently as at full load. 
Table 1. Picatinny NGEDAC theoretical performance parameters.

\begin{tabular}{|c|c|c|c|c|c|c|}
\hline $\begin{array}{c}\text { Load } \\
(\%)\end{array}$ & $\begin{array}{c}\text { Capacity } \\
\text { (cfm) }\end{array}$ & BHP & $\begin{array}{c}\text { Gas Use } \\
\text { (Btu/bhp/hr) }\end{array}$ & $\begin{array}{c}\text { Gas Use } \\
(\text { Btu/hr) }\end{array}$ & $\begin{array}{c}\text { Daily Energy Cost* } \\
(\text { Dollars) }\end{array}$ & $\begin{array}{c}\text { Air Cost } \\
\left(\$ \mathbf{1 0 0 0} \mathbf{f t}^{\mathbf{3}}\right)\end{array}$ \\
\hline 100 & 610 & 116 & 8,435 & 978,460 & 125.85 & 0.14 \\
\hline 65 & 395 & 80 & 8,250 & 660,000 & 87.64 & 0.15 \\
\hline 40 & 244 & 72 & 8,850 & 637,200 & 84.90 & 0.24 \\
\hline 28 & 175 & -- & -- & 637,200 & 84.90 & 0.34 \\
\hline
\end{tabular}

At the low load conditions of 40 percent and 28 percent, the system loses considerable efficiency as the intake flow to compressor is throttled down, but the engine speed and, hence energy use, stays relatively constant. The NGEDAC system costs more than twice as much to operate on a unit basis at 28 percent than at full load.

\section{Performance Measurement}

The actual performance of the NGEDAC unit was measured in terms of gas consumption and air flow production. Figure 2 shows the daily gas totals for the unit. The daily totals are relatively constant and fall within a range of $160 \pm 8$ percent hundred cu ft (ccf), except for 1 of the 9 days. Figure 3 shows the continuous readings for the air flow. The air flow numbers are less stable than the gas flow numbers, but cluster around 170 to $175 \mathrm{scfm}$ with periods of flow ranging from a high of $300 \mathrm{scfm}$ to a low of $0 \mathrm{scfm}$. With the full load capacity of the NGEDAC unit at $610 \mathrm{scfm}$, actual air flow use during the test period averaged 28 percent load and peaked at about 50 percent.

Air flow during the test period averaged $174 \mathrm{scfm}$ or $251,600 \mathrm{scf}$ for a day. Gas flow during the test period averaged $170 \mathrm{ccf}$ per day or $17,000 \mathrm{cu} \mathrm{ft}$ per day. Thus, the ratio (in terms of cu $\mathrm{ft}$ air/cu $\mathrm{ft}$ gas) is 14.8. As the data in Table 2 indicate, at $\$ 5.00 / 10^{6} \mathrm{Btu}$ for natural gas, the 28 percent load condition and 14.8 air to gas ratio translate into $\$ 93$ of gas per day and 37 cents $/ 1,000 \mathrm{cu} \mathrm{ft}$ of air produced. The cost estimate based on the theoretical performance supplied with the equipment specifications assumes that the gas consumption of the NGEDAC unit will not change much for flow rates below $244 \mathrm{cfm}$ or 40 percent of full load. The measurement results show that gas use was 11.1 percent more in the actual operation than predicted by the theoretical calculations. A swing of 11.1 percent is well within the level of the precision provided by the equipment specifications, the variability of the application conditions, and the measurement approach. 


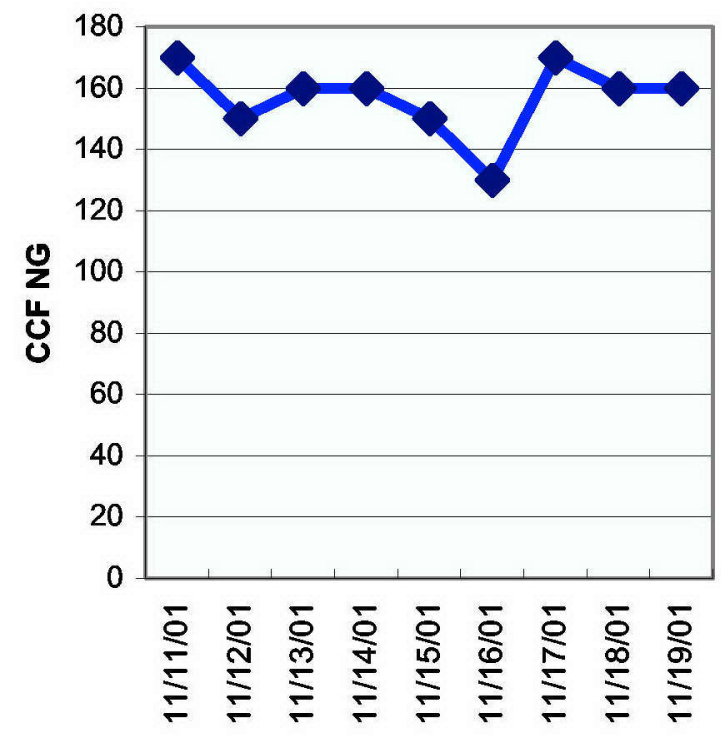

Figure 2. Picatinny Arsenal natural gas use: daily totals.

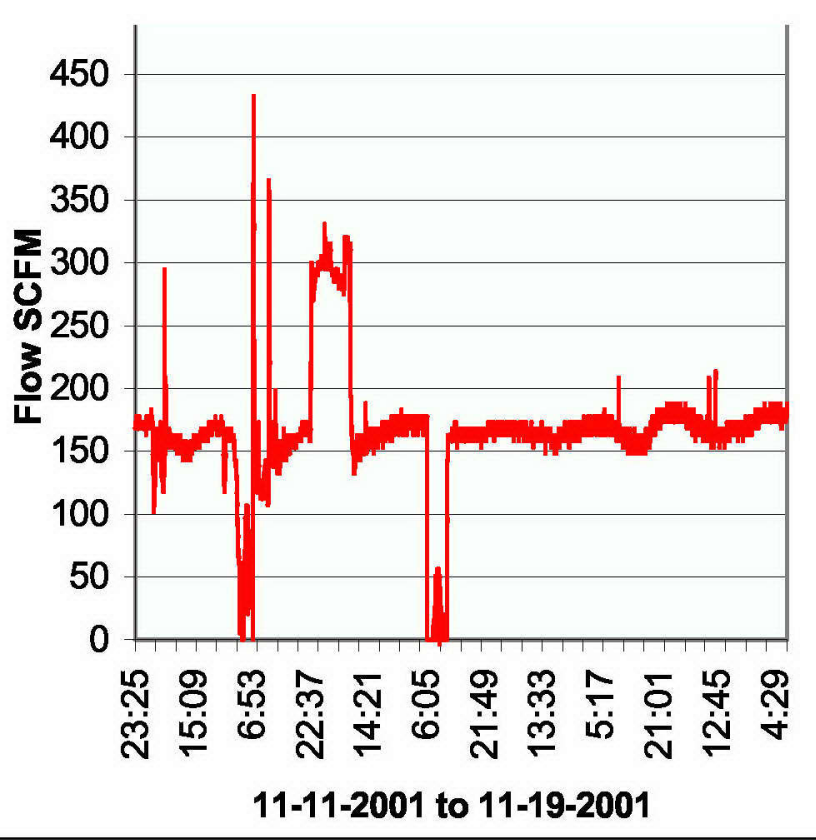

Figure 3. Picatinny measured compressed air flow.

Table 2. Picatinny NGEDAC measured performance parameters.

\begin{tabular}{|l|c|c|c|c|}
\hline Data Source & $\begin{array}{c}\text { Load } \\
(\%)\end{array}$ & $\begin{array}{c}\text { Capacity } \\
(\mathbf{c f m})\end{array}$ & $\begin{array}{c}\text { Gas Use } \\
\text { (Btu/hr at load condition) }\end{array}$ & $\begin{array}{c}\text { Daily Cost* } \\
\text { (Dollars) }\end{array}$ \\
\hline Equipment Specification & 28 & 175 & 637,200 & $\$ 84.90$ \\
\hline Measurement & 28 & 175 & 708,000 & $\$ 93.34$ \\
\hline *At a natural gas price of $\$ 5.00 / 10^{6}$ Btu and including $96 \mathrm{kWh}$ per day (or $\left.\$ 8.44\right)$ to operate the system fan. \\
\hline
\end{tabular}

\section{NGEDAC Cost Effectiveness}

The cost-effectiveness evaluation compares the operating cost of the NGEDAC unit with the existing electric unit. Table 3 lists the electrical demand and daily electric cost for the unit. At full load the existing electric unit produces 1,130 $\mathrm{cfm}$ at an electrical demand of $174.9 \mathrm{~kW}$ and an electric cost of $\$ 370 /$ day. At 15 percent loading, or the level that produces the current air flow requirement of the arsenal, the electric demand is $52.7 \mathrm{~kW}$, and the electric cost is $\$ 111 /$ day.

Table 4 lists daily energy costs of the NGEDAC unit and of the electric unit, which may be compared. The relative gas price varies from $\$ 3.41 / 10^{6} \mathrm{Btu}$, which was the gas price level at the time the original site review was conducted at $\mathrm{Pi}$ catinny, to $\$ 7.00 / 10^{6} \mathrm{Btu}$, which is a gas price level on the high end. The estimate of $\$ 5.00 / 10^{6} \mathrm{Btu}$ represents a mid-range forecast. 
Table 3. Picatinny electric air compressor theoretical performance measures.

\begin{tabular}{|c|c|c|c|c|c|}
\hline $\begin{array}{c}\text { Load } \\
(\%)\end{array}$ & $\begin{array}{c}\text { Air Flow Capacity } \\
\text { (cfm) }\end{array}$ & $\begin{array}{c}\text { Power Use } \\
(\%)\end{array}$ & $\begin{array}{c}\text { Electric Demand } \\
(\mathbf{k W})\end{array}$ & $\begin{array}{c}\text { Daily Electric Cost* } \\
\text { (Dollars) }\end{array}$ & $\begin{array}{c}\text { Air Cost } \\
\text { (\$/1000cf) }\end{array}$ \\
\hline 100 & 1130 & 100 & 174.9 & 369.38 & 0.23 \\
\hline 75 & 848 & 83 & 145.2 & 306.66 & 0.25 \\
\hline 54 & 610 & 63 & 110.2 & 232.71 & 0.26 \\
\hline 50 & 565 & 59 & 103.2 & 217.95 & 0.27 \\
\hline 35 & 395 & 45 & 78.7 & 166.22 & 0.29 \\
\hline 25 & 282 & 33 & 57.7 & 121.86 & 0.30 \\
\hline 22 & 244 & 32 & 56.0 & 118.20 & 0.34 \\
\hline 15 & 175 & 30 & 52.7 & 111.30 & 0.40 \\
\hline * Electricity cost at 8.8 cents per kWh.
\end{tabular}

Table 4. Picatinny annual energy costs of NGEDAC and electric air compressors.

\begin{tabular}{|c|c|c|c|c|}
\hline \multirow{2}{*}{$\begin{array}{l}\text { Air Flow } \\
\text { Capacity } \\
\text { (cfm) }\end{array}$} & \multicolumn{3}{|c|}{ NGEDAC Unit: Annual Energy Cost $(\$)^{*}$} & \multirow{2}{*}{$\begin{array}{c}\text { Electric Unit: } \\
\text { Annual Electricity } \\
\text { Cost }(\$)\end{array}$} \\
\hline & $@ \$ 3.41 / 10^{6}$ Btu & $@ \$ 5.00 / 10^{6}$ Btu & $@ \$ 7.00 / 10^{6}$ Btu & \\
\hline 610 & 32,300 & 45,900 & 63,100 & 84,900 \\
\hline 395 & 22,800 & 32,000 & 43,600 & 60,700 \\
\hline 244 & 22,100 & 31,000 & 42,100 & 43,100 \\
\hline 175 & 22,100 & 31,000 & 42,100 & 40,600 \\
\hline
\end{tabular}

With a flow rate at the full load condition of the NGEDAC unit, i.e., $610 \mathrm{cfm}$, the NGEDAC unit enjoys an energy cost advantage ranging from $\$ 21,800$ to $\$ 52,700$ per year, depending on the gas price scenario. For load conditions closer to the levels currently experienced by the arsenal, i.e., $175 \mathrm{cfm}$, the comparison is much closer. The gas unit is cheaper to operate by $\$ 17,500$ if gas prices are $\$ 3.41 / 10^{6}$ Btu, while the electric unit is cheaper to run by $\$ 1,500$ if gas prices are $\$ 7.00 / 10^{6}$ Btu. The NGEDAC breaks even with the pre-existing electric air compressor when natural gas prices reach $\$ 6.50 / 10^{6} \mathrm{Btu}$ and electricity is 8.8 cents per $\mathrm{kWh}$.

A couple of potential adjustments should be noted. First, the measurement analysis found that the daily energy cost was closer to $\$ 93$, not $\$ 85$ for the NGEDAC, when the price of gas is at $\$ 5.00 / 10^{6} \mathrm{Btu}$. This is a swing of $\$ 3,000$ per year at low load conditions.

A second potential adjustment centers on the maintenance contract. As part of the NGEDAC demonstration project, the arsenal has a 2-year maintenance contract on the NGEDAC engine and compressor. As such, the arsenal could disregard the maintenance cost issue in establishing protocols of whether to use the NGEDAC unit or the electric unit. 
The maintenance contract on the NGEDAC unit is priced at about $\$ 20,000$ per year or $\$ 55$ per day. If Picatinny wanted to include the maintenance costs in the total cost picture, it could simply add that figure to the NGEDAC daily costs. However, the maintenance costs for a contract to cover the electric unit would also have to be added to maintain an "apples-to-apples" comparison. The cost of a maintenance contract on the rather old XLE unit would be $\$ 16,000$ per year or $\$ 45$ per day-for a savings advantage of $\$ 10$ per day or $\$ 3,600$ for the electric air compressor.

\section{NGEDAC Application Guide}

From this assessment, an overall guideline can be developed that defines when it is preferable to operate the NGEDAC unit. The amount Picatinny spends on compressed air has been reduced from $\$ 100,000$ in the main system to less than $\$ 35,000$, when gas prices are $\$ 5.00 / 10^{6}$ Btu.

Having the ability to operate either unit, gives Picatinny the greater operating flexibility and control to address rapid spikes in fuel prices or electric curtailments and to manage compressor equipment shut downs. Note also that for a large operating band of assumed gas prices and operating load conditions, the difference in operating costs between the two units is not terribly significant on an annual basis.

A general guide to operating the compressor units would include the following:

- For main system loads greater than $400 \mathrm{cfm}$ (or 65 percent of the full load capacity of the NGEDAC), operate the NGEDAC unit as long as gas prices are less than approximately $\$ 9 / 10^{6} \mathrm{Btu}$ and electric costs average 8.8 cents per $\mathrm{kWh}$.

- For main system loads less than $250 \mathrm{cfm}$ (or 40 percent of the full load capacity of the NGEDAC unit), operate the NGEDAC as long as gas prices are less than $\$ 6.50 / 10^{6}$ Btu and electric costs average 8.8 cents per $\mathrm{kWh}$.

- All other conditions would entail operating either system or operating just the electric unit.

\section{Picatinny Project Schedule and Costs}

Site work began on 6 June 2001. Due to the long lead time for the equipment, the Project Team ordered the new compressor and cooler units 13 April 2001. The installer, Scales Air Compressor Corporation, was subcontracted on 28 June 2001. A pre-construction meeting was held 26 July 2001 at the site and construction activities to prepare the site for compressor unit delivery commenced 
immediately thereafter. When the equipment arrived, the site was ready. The system was started and commissioned the week of 8 October 2001.

The final cost for the installed system at Picatinny was $\$ 315,793$, which includes contractor general and administrative costs. Also included, is a $\$ 44,900$ for a 2 year maintenance agreement.

\section{Picatinny Level II Site Visit Summary}

During the preliminary site assessment, the Project Team identified a potential for reductions in air leaks. The air leaks were found to be on the order of 500 acfm. The Project Team assumed that the leaks identified in the Level II Audit would be repaired concurrently with the NGEDAC unit installation. With leaks repaired, the new system demand was estimated to be in the range 550 to 600 acfm. The new system was sized according to the new proposed acfm requirement. However, the demand-side reductions were much more successful than anticipated. The actual new system demands are on the order of 150 to $200 \mathrm{cfm}$.

The preliminary Level II Survey and Demand Study results were subsequently delivered to Picatinny personnel. Picatinny is using its energy savings performance contract (ESPC) with Planergy, Inc. to repair compressed air leaks.

Three projects were recommended following the Level II site evaluation.

- Project \#1: Leak Repairs

- Project \#2: System Moisture Reduction

- Project \#3: Air Driven Mixer Replacement (Bldg 39).

All Level II recommendations are being implemented under an ongoing ESPC project at Picatinny. 


\section{Watervliet NGEDAC Demonstration}

The NGEDAC unit is part of a gas/electric hybrid system capable of delivering 100 percent of the base load requirements with the NGEDAC as the primary air compressor. Watervliet will use the NGEDAC unit as their primary compressed air delivery system with the pre-existing electrically driven Ingersoll Rand unit kept in reserve service. The electric compressor will be maintained for full demand capability so that no interruptions to the compressed air service will be experienced during installation, maintenance, or unplanned downtimes of the NGEDAC system.

The design reports, a description of the installed equipment, evaluation of the NGEDAC system performance, demand-side recommendations, and project schedule and costs are discussed below.

\section{Pre-Existing Equipment}

The existing compressed air system at Watervliet Arsenal is supplied by a number of compressors spread over a large geographical area. The current distributed air system reaches most of the production areas on base and runs from building to building on a closed loop system. The current air flow requirements of the main system is approximately 2,000 to $2,500 \mathrm{acfm}$ at a supply pressure of 83 to 85 psig. The majority of the systems compressed air supply is being generated in Bldg 110 with the use of two 125-hp water-cooled Ingersoll Rand XLE (650 scfm per machine) reciprocating compressors. Unit \#1 is located in the northwest corner of the building and unit \#2 is located in the south end near a large paint booth of the building. The two main compressors feed into a 3-in. metal pipe compressed air line that connects to the main distribution loop. Air drying is provided by both desiccant and refrigeration units that appear to have sufficient capacity to maintain the compressed air at an acceptable dew point.

In addition to these two large compressors in Bldg 110, there are six smaller compressors tied in to the main air system in surrounding buildings that serve as a backup system and provide additional capacity. The base also has a 450-hp electric driven Joy three stage centrifugal compressor that is not operational. According to the Watervliet personnel, the Joy centrifugal compressor will not be repaired due to the anticipated high cost to rebuild and upgrade its controls, 
previous reliability issues, and the age of the equipment. Therefore, since the Joy Compressor is inoperable, the base does not currently have an adequate backup system in place. The current control strategy is to keep the XLE compressors in Bldg 110 online as the primary units. Several primary units and several more compressors throughout the system automatically respond to address localized short-term dips in system pressure. The pre-existing compressor units are capable of delivering the required peak load. The compressed air demand measured was determined to be relatively constant and assumed to be supplied to the system 8,760 hours per year. The complete air system appears to be well laid out, well maintained, and operated consistently with the type of controls on each compressor unit.

During the Level II site assessment, the project team identified over $700 \mathrm{acfm}$ potential reductions in air leaks. The Level II survey also indicated a peak demand of 2,100 acfm, an average production demand of 1,700 acfm and an average nonproduction load of 1,000 acfm. Subsequently, the air leaks were found to be on the order of 700 acfm on site. Vanessa Duenas, Energy Manager for Watervliet Arsenal, indicated to the project team that the tagged leaks were in the process of being repaired by the production and facility maintenance staff. Therefore, once all the leaks identified during the Level II survey have been repaired, the new system demand should be in the range of $1400 \mathrm{acfm}$. The new system was sized according to the new proposed acfm requirement. NGEDAC was sized to deliver 100 percent of the anticipated acfm average production-load requirement with the existing electric compressors acting as trim and 100 percent backup.

\section{NGEDAC Equipment}

\section{Natural Gas Engine and Compressor Unit}

The Project Team, in consultation with Watervliet Arsenal, chose a Dearing Ultra Air Model GSR-300 LW NGEDAC unit as the best match for the hybrid compressed air system. The prime mover is a Waukesha F18GLD turbocharged, liquid-cooled, natural gas engine. The engine drives a Gardner Denver rotary screw air compressor sized to deliver a maximum 1,400 acfm at 100-psig system pressure. The Waukesha F18GLD engine has a 24-volt starter, altometer, a battery set, and automatic gas shutoff valve. For protection from the elements and as a means to reducing sound levels, the Ultra Air is enclosed and equipped with a Riley-Beaird model M5 hospital-grade muffler. A Dearing Ultra-Air TR5 control system was installed providing a remote shutoff option for Watervliet personnel. 
The overall dimensions of the compressor are approximately $106 \mathrm{in}$. wide by 192 in. long by $108 \mathrm{in.} \mathrm{high.} \mathrm{Maximum} \mathrm{engine} \mathrm{fuel} \mathrm{requirements} \mathrm{are} \mathrm{approximately}$ $4,000 \mathrm{scf} / \mathrm{hr}$ of natural gas at 20 -in. w.c. (less than $1 \mathrm{psig}$ ). A pressure regulator, equipped with a pressure relief valve, is used to reduce the gas pressure between the main gas line and the NGEDAC from approximately 5 psig to $1 \mathrm{psig}$. The new compressor is located outside in a weatherproof enclosure. The enclosure for this unit is approximately 130 -in. wide by 216 -in. long by 120 -in. high.

The Project Team subcontracted with OEM equipment vendor Dearing Compressor \& Pump Company of Youngstown, Ohio to supply the NGEDAC unit and enclosure. The turnkey system installation, commissioning and O\&M training were subcontracted to general installation contractor RERO/Horizon Solutions Corporation of East Syracuse, NY, represented by Mr. Charles Neidel. RERO subcontracted certain site work to local mechanical contractor John V. Warren, Inc. of Rensselaer, NY. RERO also supplied the OEM Thermotech Corporation glycol cooler. All subcontractors were supervised by Xenergy, Inc. All subcontractors, materials and labor are the responsibility of the installation contractor.

The location of the new natural gas engine driven compressor was approximately $5 \mathrm{ft}$ from the west wall outside Bldg 110 . This location was chosen for its proximity to a firm natural gas line, a large open outside area to place the new unit, relatively easy tie-ins to the existing compressed air lines and the use of an existing 460 volt supply from the substation outside Bldg 110 adjacent to the NGEDAC. The NGEDAC is housed by a custom designed, air-cooled and weatherproof enclosure (Figure 4). A $10 \mathrm{HP}$, closed loop, fluid-cooling system using polypropylene glycol, cools the engine. To avoid contamination of intake air with the moist condenser air, the cooling tower was located to the south, downwind of the prevailing winds, of the NGEDAC and shrouded through the roof of the canopy, away from the compressor air intake. The entire mounting slab and containment curb were covered by a canopy roof structure to prevent rain and snow from displacing the containment volume.

CAD drawings were created to represent the NGEDAC unit and auxiliary equipment plans and specifications showing the pad location; pad and canopy construction details; engine exhaust location; glycol cooler, pump set and piping location, specifications and construction details; compressed air and gas piping location, specifications and construction details; and electrical feeds, circuit location, specifications and construction details. 


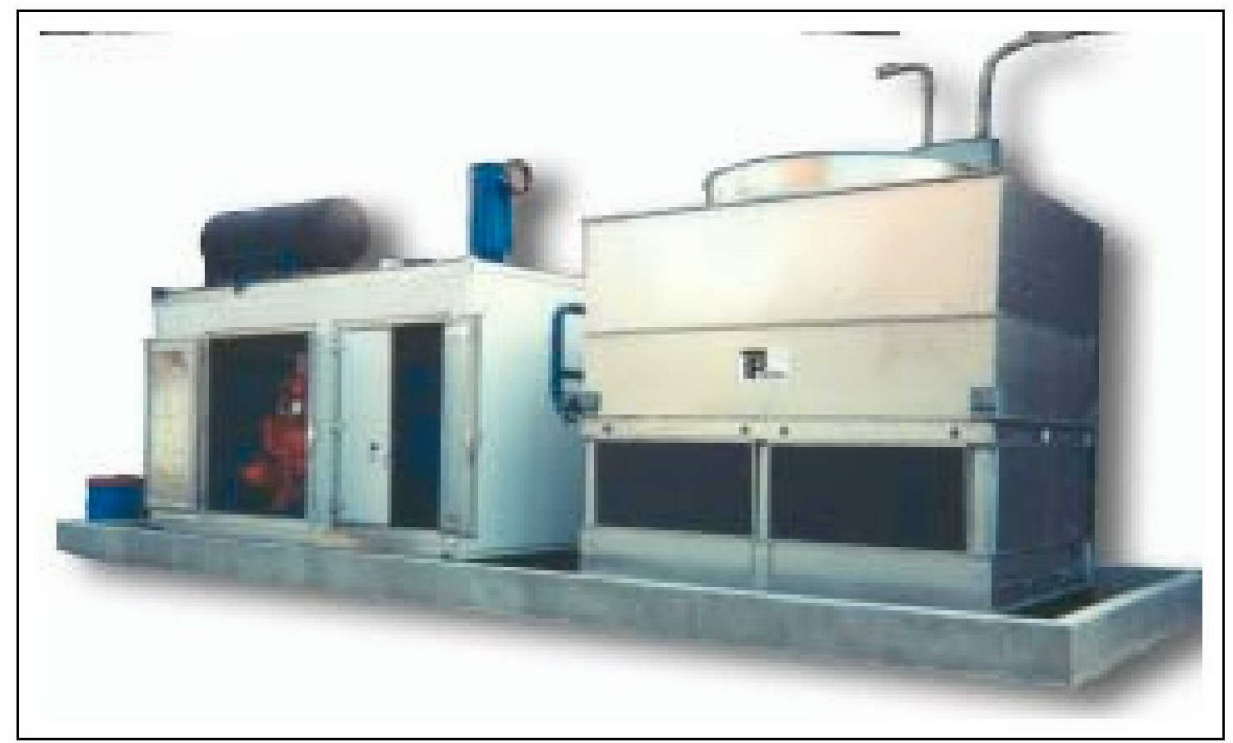

Figure 4. Dearing Ultra Air Model GSR-300LW NGEDAC installed at WVA.

\section{Closed Loop Cooling System and Evaporative Tower}

A closed loop, liquid-cooled system is required to remove waste heat from the compressor and engine. A Thermotech Model PEF-1021 induced draft counterflow closed circuit cooling system is specified. The cooling system consists of a duplex, $10 \mathrm{HP}$ pumping station using a mixture of water and polypropylene glycol and an evaporative cooling tower. The pump for the cooling unit is located inside the existing Joy compressor room and piped to the cooling unit located outside on the compressor slab.

The cooling unit has the capacity to cool 150 GPM of 40 percent glycol from 115 to $85^{\circ} \mathrm{F}$ with a $78^{\circ} \mathrm{F}$ entering wet bulb temperature. The pump station is placed on a containment pan constructed of heavy gauge G-235 hot dip galvanized steel for long life and durability. The evaporative cooling tower is located on the concrete slab with the Ultra Air gas driven air compressor inside the containment area. John V. Warren, Inc. provided all materials for this task.

The following is a description of how the gas piping, electric, compressed air and exhaust air piping were integrated into the new compressor unit enclosure.

\section{Integration with Natural Gas Fuel and Electric Power Feeds}

WVA Bldg 110 is considered to have historical significance; therefore all piping for this project was run through the interior space and did not attach anything to 
the brick fascia. All natural gas, coolant system piping, compressed air piping and electrical conduit entered Bldg 110 at a single location, through a T-111 plywood window arch adjacent to the NGEDAC installation. All compressed air, natural gas and coolant piping outside of the building envelope were insulated with weather resistant material such as Armaflex or equal.

All compressed air, natural gas and coolant piping were welded in place. For all supply and return cooling system piping not welded, flexible PVC piping were installed over the piping with rubber boots at connections as a secondary containment measure.

From the NGEDAC and its cooling tower, all piping had to go through the sheet rock wall, located on the second floor of women's bathroom, and immediately turn 90 degrees horizontally through a concrete wall. Once above the concrete wall, all piping run from the west side of Bldg 110 in an easterly direction to the catwalk. All piping were secured to the underside of the catwalk with hangers of sufficient strength to ensure permanence. Compressed air and coolant piping run north beneath the existing catwalk approximately $60 \mathrm{ft}$ where it turns 90 degrees west, through an existing opening in the inner brick wall and into the cavity above an existing mechanical room. Penetrations were made through the existing mechanical room ceiling, located for maximum convenience for connection to respective equipment located in that space.

The existing glycol cooling pump and receiver tank were disconnected by J.V. Warren, Inc and made ready for removal by WVA personnel. Glycol removed from the unit was pumped into drums specified for that purpose and provided by the WVA. The drums were removed and disposed of by WVA personnel in compliance with all appropriate hazardous waste procedures.

Cooling tower spray makeup water is obtained from the closet under the stairway in the Women's bathroom inside Bldg 110. A backflow prevention valve was installed at the point of connection in this closet in accordance with industry standards. Piping from the source to the cooling tower was through the same location as the compressed air and coolant piping. All makeup water piping outside the building envelope was insulated with weather resistant material such as Armaflex or equal.

\section{Natural Gas}

The main gas meter for the site is located at the south end of Bldg 110 in a fenced area. The gas company that is providing gas to the base is Niagara Mohawk. The Project Team decided to tie into the main firm gas line feed that runs 
through the middle of Bldg 110. The new gas connection originated at column line B32, approximately $5 \mathrm{ft}$ from the ground level inside an existing protective area. A gas shut off valve with a lock mechanism was located there. The new gas piping was a 3 -in. diameter line. The existing main natural gas supply pipe has a diameter of approximately 8 in. and has a 2-5 PSIG gas pressure. The new gas line runs through the same exterior opening with the rest of the piping and conduit. John V. Warren, Inc. made the natural gas connection and run the new gas line from the existing gas piping location to the new compressor location in the outside enclosure. John V. Warren, Inc. was responsible for all materials and labor to install to the new natural gas compressor.

According to the specification, the engine only requires $4000 \mathrm{scfh}$ of gas at a 20 in. WC pressure (less than $1 \mathrm{psig}$ ). A pressure regulator was installed to reduce the main natural gas line pressure from approximately 5 to less than 1 psig before being connected to the NGEDAC. A gas meter was installed in the new 3-in. line to monitor the natural gas usage of the NGEDAC. WVA personnel was responsible for negotiating with Niagara Mohawk for any special natural gas or electrical rates that may arise because of the NGEDAC. The gas meter specified is an American Meter Company Rotary Gas Meter Model 5500 (5.5M [3-in.]) G100 meter with a Fisher Type S201/202 gas regulator.

\section{Electric Power}

All electricity required for the NGEDAC project was fed from all existing 480volt supply located outside Bldg 110 adjacent to the NGEDAC. The 480 -volt power was delivered to a new 200-Amp main disconnect panel. Fuses were sized according to the combined load of all equipment associated with the NGEDAC project. Continuous electrical monitoring was provided by an existing Square D metering device connected at the substation. Three new disconnect switches were installed downstream of the new 200-Amp main disconnect to serve the glycol circulating pumps, the evaporative fluid cooler and 115-volt power for controls. All electrical disconnects and breaker panels were located in the Mechanical Room housing the cooling system pumps, on the wall outside the Women's bathroom or in the NGEDAC enclosure.

The original design did not include a battery charger. As a result, the engine battery would drain if the compressor unit control panel was not shut off during extended periods of nonoperation. To remedy this situation, a SENS battery charger was added to the system after the initial startup/commissioning session. 


\section{Compressed Air Lines}

The compressed air piping that is connected to the existing electric Joy Centrifugal unit is a prime location for tying into the main compressed air loop. The existing piping runs directly into a 2,800-gal storage tank then through a Van Air 2500 Internal heat dryer. The Project Team proposed to tie into the existing 6in. compressed line and use that piping to feed into the main header system. John V. Warren, Inc. provided all materials for this tie-in. All compressed air and coolant piping exposed to outside air were insulated.

\section{Outside Compressor Location and Enclosure}

Due to restricted area use and space constraints within the Bldg 110 and concern regarding noise level restrictions, the Ultra Air gas driven air compressor was housed in an outside weatherproof enclosure. The weatherproofed enclosure was equipped with openings in the floor and a 18-in. ventilation fan penetrating the ceiling of the enclosure. Access to the compressor unit is through two pairs of $4-\mathrm{ft}$ wide doors on the West side and one 3-ft door on the East. The engine control panel is accessed through a 3 -ft door on the North side of the enclosure.

The enclosure sits on a concrete slab with reinforced rebar designed to accommodate a 36,000-lb compressor load. The area also incorporates a hazardous waste containment curb, which was designed to collect any waste oil from the engine in case of a spill or equipment malfunction. The installer also installed 6-in., schedule 80 steel bollards buried $4 \mathrm{ft}$ into the ground and standing $4 \mathrm{ft}$ above ground level at the NW, SW and W center of the containment system, readily noticeable to passing vehicular traffic between the buildings. John V. Warren, Inc. provided all materials for this task.

\section{Concrete Pad and Containment}

The NGEDAC engine, compressor and cooling tower were placed on a $14 \mathrm{x} 38 \mathrm{ft}$ concrete pad and hazardous waste containment system located $5 \mathrm{ft}$ from the west side of Bldg 110. The pad has sufficient strength to withstand approximately 80 $\mathrm{lb} / \mathrm{sq} \mathrm{ft}$ load bearing capacity.

The containment area was coated with an airless brush technique using a heavy solids epoxy mastic such as Dupont Colar 25P, or equal. Contractor incorporated pumice or other acceptable substance into the coating to provide a nonslip surface. 


\section{Canopy Protection of Concrete Containment System From Weather}

To minimize rain and snow accumulation, a slant roof was installed over the entire containment system surrounding the air compressor and its cooling tower. The roof has a 3-in. rise per foot from the outside edge of the concrete slab inward toward Bldg 110, the highest pad of the roof being toward Bldg 110. The structure has vertical columns secured to the slab with epoxy anchors. The roof was constructed of corrugated steel and fastened to the vertical columns. A shroud was manufactured so that all discharge air from the cooling tower is vented through the roof.

\section{Closed Loop Cooling System and Evaporative Tower}

The pump station was placed on a containment pan constructed of heavy gauge G-235 hot dip galvanized steel for long life and durability. The evaporative cooling tower was located on the concrete slab with the Ultra Air gas driven air compressor inside the containment area. John V. Warren, Inc. provided all materials for this task.

\section{Remote Location Shut-Off of NGEDAC}

A Dearing Ultra-Air TR5 Control system was installed providing a remote shutoff option for Watervliet personnel as stipulated by their Facilities Engineering Department. Mr. George Bielkiwicz, Chief of Maintenance, Watervliet, was the primary contact to assess the best way in making this connection.

\section{Permitting and Emissions}

The NGEDAC nameplate rating was $362 \mathrm{bhp}$, which is below the trigger level of $400 \mathrm{bhp}$ for New York State air permitting requirements. The emission limits of the recommended NGEDAC equipment are:

- oxides of nitrogen

- carbon monoxide

- hydrocarbons

- nonmethane hydrocarbons
$941.2 \mathrm{gm} / \mathrm{hr}$

$633.5 \mathrm{gm} / \mathrm{hr}$

$1,810 \mathrm{gm} / \mathrm{hr}$

$271.5 \mathrm{gm} / \mathrm{hr}$.

Mr. Phil Darcy, Environmental Coordinator at WVA, provided advices to the Project Team of any possible environmental permitting requirements. He indicated that there were no permitting requirements needed for this project if the 
proposed engine remains under $400 \mathrm{BHP}$. According to the proposed system, the new engine installed has a 362 BHP rating which is lower than the State requirement. If in the course of the project that a permit is needed it will be the responsibility of the Project Team to supply the needed information to Mr. Darcy so he can apply for the permit.

\section{Compressor Efficiency and Cost Analysis Results for Watervliet}

After commissioning, the NGEDAC performance was measured. These measurements were made for a number of reasons:

- verify the performance of the gas unit against the published specifications of the unit

- establish a benchmark for the gas unit efficiency under various loads

- update the comparison of gas consumption and cost with the electric units

- verify energy savings and flow reduction associated with the demand-side projects.

\section{Theoretical Performance}

Table 5 lists the theoretical performance parameters provided with the NGEDAC equipment specifications for various loading conditions. At full load, the unit produces $1,480 \mathrm{cfm}$ and uses 2,675,180 Btu per hour of natural gas. At about two-thirds load, the unit operates 15 to 20 percent less efficiently as at full load. At a low load condition of 40 percent, the system loses considerable efficiency as the intake flow to compressor is throttled down, but the engine speed and, hence energy use, stays relatively constant. The NGEDAC system costs nearly twice as much to operate on a unit basis at 40 percent than at full load.

Table 5. Watervliet NGEDAC theoretical performance parameters.

\begin{tabular}{|c|c|c|c|c|c|c|}
\hline $\begin{array}{l}\text { Load } \\
(\%)\end{array}$ & $\begin{array}{c}\text { Capacity } \\
\text { (cfm) }\end{array}$ & BHP & $\begin{array}{c}\text { Gas Use } \\
\text { (Btu/bhp/hr) }\end{array}$ & $\begin{array}{c}\text { Gas Use } \\
\text { (Btu/hr) }\end{array}$ & $\begin{array}{c}\text { Daily Energy } \\
\text { Cost* }^{*} \\
\text { (Dollars) }\end{array}$ & $\begin{array}{c}\text { Air Cost } \\
(\$ / 1,000 \mathrm{ft} 3)\end{array}$ \\
\hline 100 & 1,480 & 362 & 7,390 & $2,675,180$ & 352.70 & 0.17 \\
\hline 74 & 1,100 & 304 & 7,380 & $2,243,520$ & 300.90 & 0.19 \\
\hline 65 & 960 & 285 & 7,375 & $2,101,875$ & 283.90 & 0.20 \\
\hline 40 & 590 & 265 & 7,495 & $1,986,175$ & 270.02 & 0.32 \\
\hline
\end{tabular}




\section{Performance Measurement}

The actual performance of the NGEDAC unit was measured in terms of gas consumption and air flow production. Figure 5 shows the daily gas totals for the unit. The gas meter was only read at the beginning of the period, after the first day, and after the seventh day. Average use over the 7-day period was $468 \mathrm{ccf}$ per day with the first day being $384 \mathrm{ccf}$ and the average for the other 6 days being $482 \mathrm{ccf}$ per day. Continuous readings for the air flow (Figure 6). The air flow numbers are less stable than the gas flow numbers, but cluster around 1,050 to $1,100 \mathrm{scfm}$ with periods of flow ranging from a high of $1,350 \mathrm{scfm}$ to a low of 900 scfm. With the full load capacity of the NGEDAC unit at 1,480 scfm, actual air flow use during the test period averaged 74 percent load and peaked at about 91 percent. Air flow during the test period averaged 1,100 scfm or 1,584,000 scf for a day. Gas flow during the test period averaged $482 \mathrm{ccf}$ per day or $48,200 \mathrm{cu} \mathrm{ft}$ per day. Thus, the ratio (in terms of cu ft air/cu $\mathrm{ft}$ gas) is 33.8. As the data in Table 6 indicate, at $\$ 5.00 / 10^{6}$ Btu for natural gas, the 74 percent load condition and 33.8 air to gas ratio translate into $\$ 289.16$ of gas per day. This results in a cost of $19 \mathrm{cents} / 1,000 \mathrm{cu} \mathrm{ft}$ for air production.

The measurements show that gas use was four percent less in the actual operation than predicted by the theoretical calculations $\left(2.146 \times 10^{6} \mathrm{Btu} / \mathrm{hr}\right.$ versus $2.244 \times 10^{6} \mathrm{Btu} / \mathrm{hr}$ ). A swing of four percent is well within the level of the precision provided by the equipment specifications, the variability of the application conditions, and the measurement approach.

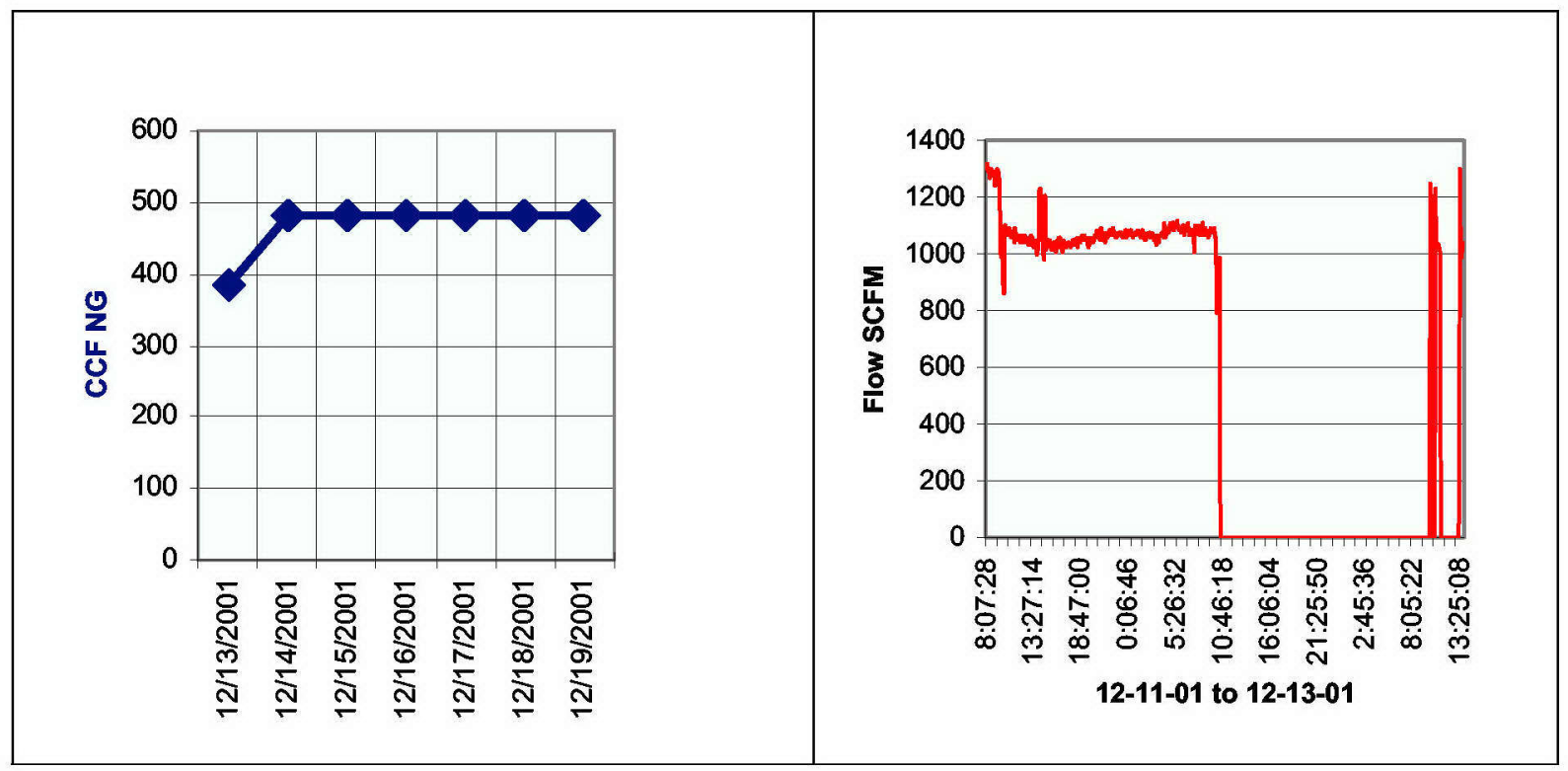

Figure 5. Watervliet Arsenal natural gas use: daily totals.

Figure 6. Watervliet Measured Compressed Air Flow 
Table 6. Watervliet NGEDAC measured performance parameters.

\begin{tabular}{|l|c|c|c|c|}
\hline Data Source & $\begin{array}{l}\text { Load } \\
\text { (\%) }\end{array}$ & $\begin{array}{l}\text { Capacity } \\
\text { (cfm) }\end{array}$ & $\begin{array}{l}\text { Gas Use } \\
\text { (Btu/hr at load condition) }\end{array}$ & $\begin{array}{l}\text { Daily Cost* } \\
\text { (Dollars) }\end{array}$ \\
\hline Equipment Specification & 74 & 1,100 & $2,243,520$ & $\$ 300.90$ \\
\hline Measurement & 74 & 1,100 & $2,145,700$ & $\$ 289.16$ \\
\hline $\begin{array}{l}\text { *At a natural gas price of } \$ 5.00 / 10^{6} \\
\text { pump. }\end{array}$ & \multicolumn{4}{|l}{ Btu and including $288 \mathrm{kWh}$ per day (or $\$ 31.68$ ) to operate the cooling } \\
\hline
\end{tabular}

\section{NGEDAC Cost Effectiveness}

The cost-effectiveness evaluation compares the operating cost of the NGEDAC unit with the existing electric unit. The pre-existing electric units are two 125 Ingersoll-Rand XLEs with $687 \mathrm{cfm}$ at $115 \mathrm{psig}$ and $128 \mathrm{bhp}$. Table 7 lists the electrical demand and daily electric cost for the unit. At full load the existing electric unit produces $1,374 \mathrm{cfm}$ at an electrical demand of $212.2 \mathrm{~kW}$ and an electric cost of $\$ 560.21 /$ day. At 80 percent loading, or the level that produces the current air flow requirement of the arsenal, the electric demand is $176.1 \mathrm{~kW}$ and the electric cost is $\$ 464.97 /$ day.

The data listed in Table 8 can be used to compare the daily energy cost of the NGEDAC unit with that of the electric unit. The relative gas price varies from $\$ 3.50 / 10^{6} \mathrm{Btu}$, which is the gas price at the low end of the spectrum, to $\$ 7.00 / 10^{6}$ Btu, which is a gas price level on the high end. Gas prices peaked over a short time period during the winter of $2000-01$ at about $\$ 10 / 10^{6}$ Btu. The estimate of $\$ 5.00 / 10^{6}$ Btu represents a mid-range forecast. With a flow rate at the full load condition of the NGEDAC unit, i.e., $1,480 \mathrm{cfm}$, the NGEDAC unit enjoys an energy cost advantage ranging from $\$ 44,700$ to $\$ 127,600$ per year, depending on the gas price scenario. For load conditions closer to the levels currently experienced by the arsenal, i.e., $1,100 \mathrm{cfm}$, the comparison is much closer. The gas unit is cheaper to operate by $\$ 89,400$ if gas prices are $\$ 3.50 / 10^{6}$ Btu and by $\$ 20,600$ if gas prices are $\$ 7.00 / 10^{6} \mathrm{Btu}$. The NGEDAC breaks even with the pre-existing electric air compressor when natural gas prices reach about $\$ 8 / 10^{6}$ Btu and electricity is 11 cents per $\mathrm{kWh}$.

A potential adjustment on this analysis centers on the maintenance contract. As part of the NGEDAC demonstration project, the arsenal has a 2-year maintenance contract on the NGEDAC engine and compressor. As such, the arsenal could disregard the maintenance cost issue in establishing protocols of whether to use the NGEDAC unit or the electric unit. 
Table 7. Watervliet Electric air compressor theoretical performance measures.

\begin{tabular}{|c|c|c|c|c|c|}
\hline $\begin{array}{c}\text { Load } \\
(\%)\end{array}$ & $\begin{array}{c}\text { Air Flow } \\
\text { Capacity } \\
(\mathrm{cfm})\end{array}$ & $\begin{array}{c}\text { Power } \\
\text { Use } \\
(\%)\end{array}$ & $\begin{array}{c}\text { Electric } \\
\text { Demand } \\
(\mathrm{kW})\end{array}$ & $\begin{array}{c}\text { Daily Electric } \\
\text { Cost }(\$)^{*}\end{array}$ & $\begin{array}{c}\text { Air Cost } \\
(\$ / 1000 \mathrm{cu} \mathrm{ft})\end{array}$ \\
\hline 108 & 1,480 & 108 & 228.6 & 603.50 & 0.28 \\
\hline 100 & 1,374 & 100 & 212.2 & 560.21 & 0.28 \\
\hline 80 & 1,100 & 83 & 176.1 & 464.97 & 0.29 \\
\hline 70 & 960 & 75 & 160.0 & 422.40 & 0.30 \\
\hline 43 & 590 & 54 & 114.3 & 301.75 & 0.36 \\
\hline * Electricity cost at 11 cents per kWh.
\end{tabular}

Table 8. Watervliet annual energy costs of NGEDAC and electric air compressors.

\begin{tabular}{|c|c|c|c|c|}
\hline \multirow{2}{*}{$\begin{array}{c}\text { Air Flow } \\
\text { Capacity }(\mathrm{cfm})\end{array}$} & \multicolumn{2}{|c|}{ NGEDAC Unit: Annual Energy Cost $^{*}(\$)$} & $\begin{array}{c}\text { Electric Unit: } \\
\text { Annual Electricity } \\
\text { Cost }(\$)\end{array}$ \\
\hline 1,480 & 93,600 & 128,700 & 175,600 & 220,300 \\
\hline 1,100 & 80,300 & 109,800 & 149,100 & 169,700 \\
\hline 960 & 76,000 & 103,600 & 140,400 & 154,200 \\
\hline *Includes $\$ 11,560$ & $@ \$ 5.00 / 10^{6} \mathrm{Btu}$ & $@ \$ 7.00 / 10^{6} \mathrm{Btu}$ & \\
\hline
\end{tabular}

The maintenance contract on the NGEDAC unit is priced at about $\$ 45,000$ per year or $\$ 123$ per day. If Watervliet wanted to include the maintenance costs in the total cost picture, it could simply add that figure to the NGEDAC daily costs. However, the maintenance costs for a contract to cover the electric unit would also have to be added to maintain an "apples-to-apples" comparison. The cost of a maintenance contract on the pre-existing XLE units would be $\$ 22,000$ per year or $\$ 60$ per day-for a savings advantage of $\$ 60$ per day or $\$ 21,900$ for the electric air compressor.

\section{NGEDAC Application Guide}

From this assessment, an overall guideline can be developed that defines when it is preferable to operate the NGEDAC unit. The amount Watervliet will be spending on compressed air has been reduced from $\$ 360,000$ (i.e., the electric cost the arsenal would have incurred in the Main System using 11 cents per $\mathrm{kWh}$ and the centrifugal compressor units) to less than $\$ 120,000$. About a third of this reduction $(\$ 80,000)$ is the result of lower production costs for the NGEDAC unit and the other two-thirds of the reduction $(\$ 160,000)$ is the result of reducing air flow requirements by almost half as a result of implementing the demand-side recommendations. 
Having the ability to operate either the NGEDAC or the electric units, gives Watervliet the greater operating flexibility and control to address rapid spikes in fuel prices or electric curtailments and to manage compressor equipment shutdowns and maintenance expenses. A general guide to operating the compressor units is quite simple:

- Use the NGEDAC unit as long as air requirements are above $960 \mathrm{cfm}$ and gas is less than $\$ 8.00 / 10^{6} \mathrm{Btu}$ and electric costs average 11 cents per $\mathrm{kWh}$.

- If electric costs go up, then a higher threshold gas price would be applicable.

- If electric costs go down, a lower threshold gas price would be applicable.

- The gas price cut-off might move down to $\$ 7.00 / 10^{6} \mathrm{Btu}$ if the maintenance contract costs are included.

\section{Project Schedule and Costs}

Project site work began on 2 July 2001. Due to the project funding expiration constrain, it is necessary to complete the project by the end of fiscal year 2001, certain equipment purchases and site construction activities had to be undertaken before the approval of the 100 Percent Design Package. Because of the long lead time, the Project Team ordered the new compressor and cooler units on 12 April 2001. The installer, RERO/Horizon, and their mechanical contractor, John V. Warren, Inc., started to prepare the area prior to the delivery of the compressor. Construction was essentially completed and the system was commissioned the week of 5 November 2001. Punch list items remained to be completed as of 31 December 2001 were provided to the Arsenal. Final punch list items were completed by February 2002.

The final cost for the installed system at Watervliet was $\$ 701,649$, which includes contractor general and administrative costs. Also included, is $\$ 99,201$ for a 2-year maintenance agreement.

\section{Level II Site Visit Summary}

During the Level II site assessment, the Project Team identified a potential for reductions in air leaks. The air leaks were found to be on the order of $700 \mathrm{acfm}$. The Watervliet Department of Public Works indicated to the Project Team that leaks were in the process of being repaired on the production side and are to be repaired internally by base personnel on the facility side. For purposes of the final design, the Project Team assumed that the leaks identified during the Level II Audit would be repaired concurrently with the NGEDAC unit installation. 
Therefore, once all the leaks identified during the Level II Survey have been repaired, the new system demand should be in the range 1,400 acfm.

\section{Level II Recommendations}

Six projects were recommended following the Level II site evaluation.

- Project \#1: Repair compressed air leaks

- Project \#2: Eliminate 1/4-in. blowoff in the plating pit of Bldg 35

- Project \#3: Shut off glycol pump for Joy Air Compressor

- Project \#4: Replace Vortec cabinet coolers

- Project \#5: Replace timer drains with float-type drains

- Project \#6: Upgrade control and drying systems.

The total estimated costs for these projects are $\$ 83,600$ to $\$ 98,600$, with an estimated annual savings of $\$ 107,300$.

Watervliet Arsenal accepted these recommendations in a report dated $27 \mathrm{March}$ 2001 with the intention of completing the recommendations using in-house maintenance staff. As of 31 December 2001, some of the recommendations have been implemented, including Project \#1 (partially) and Project \#3 (fully). 


\title{
5 Sierra NGEDAC Demonstration
}

The SIAD compressed air system survey focused on the feasibility of installing a $125 \mathrm{hp}, 600 \mathrm{scfm}$ natural gas engine driven air compressor as a direct replacement for the existing electric motor driven air compressor of the same capacity. The existing unit is housed in Bldg 210 but serves as the central compressed air source for two other buildings (208 and 209). Adequate space exists within this building for the NGEDAC. Natural gas is available and heat recovery for space heating appears promising.

\section{Pre-Existing Equipment}

The compressed air system has three compressors:

$\begin{array}{ll}\text { Compressor \#1: } & \\ \text { Manufacturer: } & \text { Gardner Denver } \\ \text { Model: } & \text { EDMQNA } \\ \text { Nominal Power: } & 125 \mathrm{HP} \\ \text { Rated Capacity: } & 600 \mathrm{icfm} \\ \text { Rated Supply Pressure: } & 100 \mathrm{psig} \\ \text { Voltage: } & 460 \mathrm{VAC} / 3 \text { phase/ } 60 \mathrm{~Hz} \\ \text { Full Load Current: } & 154 \text { amps } \\ \text { Date of Manufacture: } & \text { December } 1994\end{array}$

The Gardner Denver is the main air compressor that is used on a continuous basis. Its air is used both for tool operation and breathing air. It is located in the Paint Shop (Bldg 210).

\author{
Compressor \#2: \\ Manufacturer: Ingersoll-Rand \\ Model: SSR EP200 \\ Vintage: 1989 \\ Nominal Power: $200 \mathrm{hp}$ \\ Rated Pressure: 125 psig \\ Maximum Pressure: 135 psig \\ Electrical Connect: $460 \mathrm{~V} / 60 \mathrm{~Hz} / 3 \mathrm{ph}$ \\ Air Capacity: 892 acfm at 125 psig
}

This $200 \mathrm{hp}$ Ingersoll-Rand is the backup compressor and it is occasionally used if Gardner Denver compressor is down or it can not meet the facility air demand. 
This $200 \mathrm{hp}$ compressor is located in the compressor room inside the Metal Shop (Bldg 209).

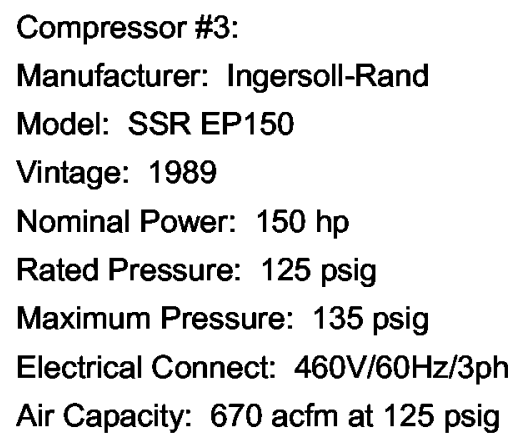

The $150 \mathrm{hp}$ Ingersoll-Rand air compressor was moved to SIAD from Sacramento Army Depot and it has never been used. This $150 \mathrm{hp}$ compressor is located in the compressor room inside the Metal Shop (Bldg 209).

\section{Breathing Air System}

To comply with the Army Respiratory Protection Program requirements, an oilless compressor is needed for breathing air generation at SIAD. However, currently breathing air is supplied by the Gardner Denver compressor (not an oilless compressor) to the paint and shot blast booths. Dried compressed air is treated by a Nomonox Purifier Model CDP806S with a capacity of 172 SCFM (at 100 psig). Upstream of the purifier there are two filters, one air/moisture separator (Hankinson Model A350-16-5-G) and one colorguard pre-filter (Zeks Model F500). There are also two filters downstream of the purifier: one for CO removal, and one for odor removal (Zeks Model 330 PC). Before introduction into the booths, two Toxgard gas monitors monitor the CO content of the breathing air. A back-up air purifier has been installed in the main compressor room. The system capacity is 301 SCFM at 100 psig.

Breathing air is needed for the paint booths and shot blast booth operators. It is tested every 6 months by an outside firm (TRI/Environmental, Inc.). Carbon monoxide (CO) is continuously monitored on line for both operations.

\section{NGEDAC Equipment}

The following description outlines the requirements for the NGEDAC at Sierra Army Depot that resulted from the site visits. 
The packaged natural gas engine-driven air compressor (NGEDAC) will consist of a single factory assembled and tested, skid mounted assembly of a natural gas engine, screw compressor, controls, and auxiliary equipment that allow the compressor to operate as a standalone air compressor system. The packaged system will be designed to operate under a variable speed operating scenario to take advantage of the part load operating efficiency of the combined engine and compressor technologies. The system will be supplied with equipment to allow for heat recovery to a new hydronic loop and then air cooled for heat rejection to meet the packaged system cooling requirements.

The NGEDAC may be sized to meet the compressed air requirements that are currently being met by the existing electric motor-driven screw compressor. However, the capacity of the NGEDAC will only be finalized after baseline measurements of compressed air loads are completed. These measurements will establish the air flow requirements for processes to be served by the NGEDAC and breathing air processes to be served by a dedicated electric motor-driven oilfree air compressor.

\section{System and Component Overview}

This section provides information on the design considerations and requirements for the system and major components:

1. NGEDAC location and enclosure

2. Natural gas fuel connection

3. Engine/compressor inlet air system

4. Engine exhaust system

5. Compressed air discharge line

6. Breathing air compressor system

7. Cooling system

8. Heat recovery system

9. Control system.

\section{NGEDAC Location and Enclosure}

The NGEDAC will be installed in the vacant area at the back (north-end) of the current compressor room. The room where the NGEDAC will be installed will require some structural renovations:

1. Refurbish the roof to be weather proof

2. Ensure that the foundation will support the equipment and pad weight load and design modifications 
3. Provide adequate ventilation to cool the air compressor

4. Provide adequate heating to prevent freezing of the heat recovery loop

5. Maintain adequate sound levels in adjacent work areas.

The current roof leaks during heavy rains. This issue needs to be addressed and resolved. The floor of the building is cracked and the structural integrity for supporting an air compressor is in question. The floor will be analyzed for structural integrity. If required, appropriate vibration absorption will be included.

The enclosure will be modified to provide ambient air for system cooling. This shall be accomplished through the use of exhaust fans with appropriate air inlet into the space. The design will take into account all sources of heat within the compressor area. Supplemental enclosure heating may need to be provided to prevent freezing of the heat recovery loop during the winter months.

\section{Natural Gas Fuel Connection}

Bldg 210 has a utility gas main and pressure regulator located outside (westend), at a distance of approximately $120 \mathrm{ft}$ from the main compressor room. The current gas pressure regulator is set at 14 -in. w.c. The NGEDAC unit will require gas pressure of 2 to 5 psig. Increasing the pressure at the main pressure regulator will require that the regulators for the existing space heating units be replaced to accommodate the increased pressure. Base personnel indicted that this can be easily accommodated. The gas line would need to be extended into the building (\#210) approximately $20 \mathrm{ft}$ and then run along the ceiling down to the compressor room and back to the location of the engine-driven unit. The estimated total natural gas piping run is $200 \mathrm{ft}$.

In addition, a temperature and pressure compensated gas meter with a visual counter and a pulse signal output shall be included in the design. The gas meter installation design will include bypass piping so that the meter may be removed without impacting the operation of the compressor package.

\section{Inlet Air System}

For optimum performance, piping or ducting will be installed to provide clean outside air to both the engine and compressor and intake filters. The installation of the NGEDAC will require some ducting to vent the engine exhaust in a manner that prevents it from mixing with the compressor inlet air. The engine exhaust may trip the alarm for the breathing air purification system. To ac- 
commodate this requirement the proposed engine and compressor Inlet Air System (IAS) requires the installation of inlet air ducting to the new NGEDAC and the existing electric air compressor. The inlet ducting would be run towards the building and extended upward. The resulting distance between the inlet air and the engine exhaust will be approximately $50 \mathrm{ft}$.

\section{Engine Exhaust System}

The Engine Exhaust System (EES) will be designed to vent the exhaust gas in a manner that assures personnel safety. In addition, the EES system will be designed such that the exiting exhaust is not in close proximity to the air inlet of the system. The piping will be designed for the rated flow, backpressure and temperature as specified by the NGEDAC manufacturer. The exhaust piping will be properly supported and insulated to protect building materials and personnel from the hot surfaces.

The NGEDAC will be supplied with a catalytic converter that will be sized to meet California and Base environmental permit requirements.

\section{Compressed Air Discharge Line}

The compressed air discharge of the unit shall be interfaced in the existing compressed air piping between the discharge of the existing compressor and the existing receiver. For the purposes of performance monitoring, the design will include the following provisions:

1. Thermowell (for temperature measurement)

2. Isolated female $1 / 2$-in. NPT fitting for an electronic pressure transducer.

3. Provision for a temporary air flow meter

\section{Breathing Air Compressor System}

The Army is requiring that all breathing air be supplied by means of oil-free compressors. The installation of a new electric motor-driven oil-free compressor will be included as part of the overall NGEDAC project. The existing system has a breathing air filter and distribution system to meet breathing air requirements. The new oil-free compressor will be interfaced into the breathing air filter branch of the system. The compressed air piping will be modified to accommodate the oil-free compressor and to isolate the breathing air stream from the process air stream. The oil-free compressor will be located in the existing com- 
pressor room. The design shall provide for the required electrical interface and appropriate controls.

\section{Cooling System}

The compressor package will be supplied with several external cooling systems. These will consist of:

1. Engine cooling radiator

2. Compressor cooling radiator

3. Compressed air aftercooler

4. One or more heat recovery heat exchangers.

These systems will be installed in close proximity to the NGEDAC in compliance with the manufacturer's specifications.

\section{Heat Recovery System}

There are no process hot water loads within the three buildings that use the compressed air. However, waste heat from the NGEDAC can be used to offset space heating requirements. The proposed heat recovery option is to install a hydronic space heater in Bldg 210. There are currently gas-fired space heaters suspended from the ceiling throughout the building. The proposed heating system (using heat recovered from the NGEDAC) will directly off-set the heating requirement of the existing suspended gas heaters. The heat recovery equipment will consist of:

1. Heat recovery heat exchanger option on the NGEDAC

2. Interface copper piping

3. Circulation pump

4. Forced air hydronic heating units

5. Controls.

The hydronic heating unit will be suspended from the ceiling near the entrance of the main compressor room. The heat recovery heat exchanger is estimated to provide approximately 200,000 Btuh of heat from the NGEDAC.

The building is approximately $18,000 \mathrm{sq} f t$ in area and lacks adequate insulation. The ceiling in the center of the building is in excess of $30 \mathrm{ft}$ high. It is projected that the new space heater would be capable of providing about 200,000 Btuh from the new compressor into the conditioned space 100 percent of the occupied hours during the months of October through April. 
Waste heat from the NGEDAC engine jacket water and compressor oil will be recovered through manufacturer supplied heat exchangers. The heat recovery shall be implemented such that the compressor package provides adequate cooling to the engine and compressor during times of low or no heat recovery from the facility. Circulation devices between the compressor package and the heat recovery heat exchangers will be included as part of the compressor package by the compressor manufacturer. It may be assumed that remotely placed heat exchangers will be placed on the compressor equipment pad and in close proximity to the compressor. The heat recovery design will include the process-side interface and control design.

For the purposes of performance monitoring, the design will include the following provisions:

1. Thermowell in process water supply line (water supply temperature)

2. Thermowell in process water return line (water return temperature)

3. Water flow meter in process water supply line (water flow rate).

\section{Control System}

A control system will be supplied with the NGEDAC that provides for the sequence of operation for the packaged air compressor system, instrumentation, alarming and interface to the other stationary air compressors on the compressed air system.

1. Sequencing control: start, stop, system backup

2. Regulation: full or part load operation, idling operation

3. Protection: alarms, shutdown (equipment/personnel safety)

4. Diagnostics: internal engine parameters (system health).

Sequence of operation control will provide for the prescribed start-up sequence for the engine and compressor, full load and part load operation, idling operation, and shut down sequences from alarms.

\section{Backup Control-Sequencing with Other Stationary Compressors}

The system will have following backup controls:

- The NGEDAC package controls will be interfaced with the existing compressor such that when the NGEDAC is unable to operate when there is a demand for compressed air, the existing electric compressor will operate to supply the compressed air load. 
- The compressor package controls will be interfaced with the existing compressor in Bldg 210 such that when the existing electric compressor is unable to operate and there is a demand for compressed air, the NGEDAC will operate to supply compressed air.

- The NGEDAC will have controls that allow the facility to schedule enginedriven air compressor operation during peak electric time periods

\section{Performance Verification Test Plan}

Monitoring of the existing electric motor-driven air compressor air serves two purposes:

1. It provides baseline data for benchmarking the NGEDAC performance. The baseline data will be collected to provide information about the energy use of the existing compressor under typical operating conditions.

2. It provides information for sizing the NGEDAC and new oil-free compressor for breathing air. This is needed since only information on total air flow (process air plus breathing air combined) based on the compressor design capacity rating is available.

Monitoring of the compressed air system after installation of the NGEDAC and the oil-free air compressor will be conducted to determine the energy performance of the new system. This will be done in two steps:

1. Monitoring with the NGEDAC in operation

2. Monitoring with the NGEDAC off and the backup (existing) electric motor-driven air compressor providing the process air.

The energy performance of the NGEDAC and associated energy operating costs will be compared to the energy and costs associated with: (1) operation of the electric motor-driven air compressor prior to the NGEDAC installation, and (2) operation of the electric motor-driven air compressor as the backup. The second comparison is needed to account for the situation that would have existed had the NGEDAC demonstration not taken place. SIAD would still have had to install a dedicated oil-free air compressor for the breathing air, leaving the existing electric motor-driven air compressor to provide the process air. Since the existing compressor would have been meeting a smaller compressed air load (at least whenever breathing air was required), this would have affected its performance. By operating the electric motor-driven air compressor instead of the NGEDAC, it will be possible to determine the actual performance of the electric motor-driven air compressor under the reduced load situation (serving process load only). 
The tasks required for the monitoring of both systems are:

1. Provide monitoring system hardware.

The monitoring system, sensors, power supplies, enclosures and wiring to support a temporary monitoring project must be provided. The monitoring system will use calibrated equipment that is not the property of SIAD or the Government.

2. Install monitoring system.

The monitoring system, consisting of a wattmeter, pressure sensor and air flow meters will be installed. There are no provisions in the compressed air piping for these sensors so sensor interfaces will be required as appropriate. The data logger will be programmed to scan sensors, convert the signals to engineering units, and store data. Once the system is installed, the readings will be verified.

3. Undergo monitoring period.

The monitoring period shall be a minimum of 1 week for the electric motor-driven air compressor system (pre-NGEDAC installation monitoring) and a minimum of 2 weeks for the NGEDAC system. SIAD operates 10 hours per day Monday through Thursday. A 1-week monitoring period will result in 40 to 44 hours of operating data. It is intended to collect 8 working days of compressor operation over a 14-day period.

4. Monitoring system removal.

At the end of the monitoring period, the monitoring system and sensors will be removed.

5. Perform data analysis and reporting.

The data will be collected and organized in an electronic format (MS Excel or comma-separated variables). All data shall be consolidated into one file. Each data record will start with a date and a time stamp. A data summary report will be developed that summarizes the typical (average) daily compressed air load profile and summarizes the compressor operating efficiencies at various loading levels. The anticipated loading levels will be 30, 50, 75, and 100 percent. These are target levels that may or may not be exact. It is anticipated that operating data will be segmented into data bins in approximately 5 percent brackets. The hours of operation of each bin will be summarized. Bins that have a statistically significant quantity of data will be used to develop an efficiency map of the compressor.

6. Monitoring Points - Electric Motor-Driven Air Compressor System.

The required monitoring points are:

a. Electric air compressor energy consumption $(\mathrm{kW})$

b. Compressor discharge air pressure (psig)

c. Compressor discharge air temperature $\left({ }^{\circ} \mathrm{F}\right)$

d. Compressor total air flow rate (scfm)

e. Process air flow rate (scfm)

f. Compressor inlet air temperature $\left({ }^{\circ} \mathrm{F}\right)$ and relative humidity $(\% \mathrm{RH})$ 
g. Outside air temperature $\left({ }^{\circ} \mathrm{F}\right)$ and relative humidity (\%RH) (Note that the breathing air load will be calculated as the difference between the total compressor discharge air and the process line air flows).

7. Monitoring Points-NGEDAC System.

The required monitoring points are:

a. Natural gas flow (cfm)

b. Isolated engine speed (rpm)

c. System on/off status (dry-contact)

d. Compressor discharge air pressure (psig)

e. Compressor discharge air temperature $\left({ }^{\circ} \mathrm{F}\right)$

f. Compressor total air flow rate (scfm)

g. Compressor inlet air temperature $\left({ }^{\circ} \mathrm{F}\right)$ and relative humidity (\%RH)

h. Outside air temperature $\left({ }^{\circ} \mathrm{F}\right)$ and relative humidity $(\% \mathrm{RH})$

i. Heat recovery flow rate (gpm)

j. Heat recovery inlet and outlet fluid temperatures $\left({ }^{\circ} \mathrm{F}\right)$.

\section{Sensor Installation}

There are currently no penetrations in the compressed air piping to accommodate the air flow or pressure measurements. Appropriate sensor locations will be identified and provisions will be made for the installation of sensors.

8. Sensor Scan Rate.

The sensors will be scanned at a rate of no less than once per minute and preferably at a rate of once every 2 seconds.

9. Data Records.

Data records shall consist of statistical representations of the scanned data that represent compressor operation at 15-minute intervals. Each data record shall have a date and time stamp. Time intervals shall be coincident with the quarter hour (e.g. :00, :15, :30 and :45) resulting in 96 records per day. The format of the data records is to be:
a. Year
b. Day
c. Time (24 hour clock)
d. Record minutes
e. Average compressor electric power $(\mathrm{kW})$
f. Average compressor discharge pressure (psig)
g. Average compressor flow (scfm)
h. Average process air flow (scfm)
i. Average compressed air temperature $\left({ }^{\circ} \mathrm{F}\right)$
j. Average outdoor ambient temperature $\left({ }^{\circ} \mathrm{F}\right)$
k. Average outdoor ambient relative humidity (\%RH)
1. Maximum compressor power (kW) 
m. Maximum compressor flow (scfm)

n. Maximum breathing air flow (scfm)

o. Minimum compressor power $(\mathrm{kW})$

p. Minimum compressor flow (scfm)

q. Minimum breathing air flow (scfm).

\section{Engineering Design}

\section{Background}

The firm of Walsh Engineers of San Diego, CA was selected to develop the detailed engineering design for the project. Using the conceptual design as a basis, Walsh Engineers developed a set of drawings and specifications for the installation of the NGEDAC unit to provide process air and the electric motor driven oilfree air compressor for breathing air. Prior to embarking on the engineering design, Walsh Engineers participated in a preliminary site visit and review meeting at SIAD, which was also attended by representatives of CERL and SAIC. The site visit and conceptual design review was held at Sierra Army Depot on 17 October 2001.

Site coordination, schedules and installation requirements were discussed. In addition, there was a discussion regarding the support of SIAD for the installation of the oil-free compressor. SIAD has in-house capabilities in the areas of electricians and carpenters. It was requested that SIAD provide the electrical service for the oil-free compressor and new equipment ancillaries as well as improvements to the compressor room to ensure weatherization of the building. SIAD notified SAIC that the base is located in seismic zone 3 and that this should be taken into account in the design. SAIC agreed to have Walsh Engineers contract for a core sample of the existing compressor room slab to determine its adequacy to support the additional loads imposed by the new compressors. The structural analysis was performed and this led to the conclusion that the existing slab would not properly support the weight of the new compressors.

A set of drawings was generated at the 65 percent design completion point, detailing the basic aspects outlined in the conceptual design, and incorporating the results from the 17 October site visit and meeting. These drawings were reviewed with SIAD and CERL at a design review meeting held on 27 November 2001 at SIAD. The following discussion provides information about some of the major design features, including changes relative to the conceptual design that became part of the final design. 


\section{Basic Features and Changes Relative to Conceptual Design}

The design is based on the installation of the natural gas engine-driven air compressor and an oil-free air compressor in the back room of the existing compressor room of Bldg 210. The engine-driven air compressor is dedicated to process air requirements and the oil-free air compressor is dedicated to the breathing air requirements. The equipment layout in the final design changed from the conceptual design. The conceptual design had the engine-driven air compressor in the back room and the oil-free compressor in the same room as the existing electric air compressor. Walsh Engineers determined that functionality of the existing compressor room should be maintained and that both new compressors would fit in the back room. It was determined that the proposed configuration would maintain the ability to remove the Nomonox system or electric air compressor from the room for repair or maintenance if required. Access to the new compressors will be adequate through the new doors on the back of the compressor room building.

New concrete support pads for each of the compressors was specified based on the structural loads imposed by the units. The specification identified cutting and removal of portions of the existing slab, the excavation of the same area for footers and the new support pads, and the pouring of new, thicker pads.

The oil-free compressor is interfaced with a new receiver and a new dryer. The design for the compressed air piping involves connecting the compressed air from the engine-driven unit into the outlet of the existing electric compressor prior to entering the existing receiver. The oil-free compressor is interfaced so that it can be isolated to the breathing air line through the Nomonox systems. In the case of a failure of the oil-free unit, the piping and valving allows for breathing air to be provided by the process air compressors. The controls allow for the operation of the existing electric air compressor in the event of a failure of the new natural gas engine-driven air compressor.

The compressed air inlet for all three compressors is interconnected and run back toward the main building above the roof. This was incorporated into the design to address problems with the breathing air contamination due to trucks idling outside the building.

\section{Heat Recovery}

Heat recovered from the NGEDAC is used to preheat outside air entering one of the makeup air units for the paint booths. This is a change from the conceptual design, which included heat recovery as a source of heat for Bldg 210. The con- 
ceptual design specified mounting a hydronic heating fan coil unit from the ceiling, near the front of the compressor room. The final design is based on installing a hydronic heating coil inside one of the existing makeup air units. This approach allows the heat recovered from the air compressor to preheat the makeup air prior to entering the burner section of the makeup air unit. This approach directly offsets a portion of the natural gas consumption of the makeup air unit.

\section{Natural Gas Interface}

The natural gas interface requires that the supply pressure be increased to 5 psig. This requires the addition of regulators to reduce the pressure back down to 12 in. w.c. for the makeup air unit burners.

\section{Electrical Interface}

The electrical interface requires two types of service into the compressor room. The oil-free compressor requires 460 , three-phase VAC and the remaining electric requirements require 208/120 single phase VAC.

\section{Equipment Purchase, Installation, and Start-Up}

\section{Compressor Equipment Purchase Process}

The acquisition of the NGEDAC and the electric motor driven oil-free air compressor was separated from the acquisition of installation services to meet the overall project schedule and potentially reduce overall project costs. It was determined that the NGEDAC was the long-lead time item (e.g., up to 16 weeks, according to some manufacturer estimates), and would need to be ordered even before the engineering design was complete. Accordingly, a request for quotation (RFQ) was developed for the compressors using the conceptual design document as a basis for the bid specifications. One area of uncertainty that complicated the process, and delayed issuance of the RFQ was the determination of the air capacity requirements for each compressor. Whereas the existing electric motor driven air compressor at SIAD was providing compressed air to serve both breathing air needs and process air requirements, the NGEDAC would only need to meet the process air loads. The new electric motor driven oil-free air compressor was expected to meet the breathing air needs. Therefore, it was decided that it was important to establish what the individual breathing air and process air requirements were. This was accomplished by monitoring of the existing air compressor system. 
The air flow measurements indicated a significant variability in the process loads, with total loads on the order of one-third to one-half of the nominal 600 icfm capabilities of the existing compressor. Only during short durations were loads observed that were anywhere near the design capabilities of the compressor. Complicating this situation was uncertainty in the degree to which the data collected reflected typical base operating conditions. The monitoring began just prior to the 11 September 2001 attack on the World Trade Center in New York City and was disrupted by the temporary shutdown at SIAD in response to this event. When SIAD resumed operations on 16 September, the level of base activity had changed. Furthermore, SIAD staff indicated that increased activity at the base was probable, adding to the uncertainty in using the measurements for compressor sizing.

Given the uncertainty, researchers attempted to establish likely capacity needs by looking at process equipment compressed air requirement ratings (e.g., range of air flows for each paint spray booth, or process equipment, etc.), and estimating likely and maximum usage (e.g., number of paint spray booths typically in operation, total number of booths available, etc.). Some of this information had been collected during the earlier site evaluations, but was updated with the assistance of SIAD staff. In addition, the research team performed economic analyses of different capacity compressors (e.g., $125 \mathrm{hp}, 600 \mathrm{icfm}$ design capacity, representing the same capacity as the existing electric air compressor and 100 hp, $490 \mathrm{icfm}$ design capacity, representing a unit more closely matched to the measured process load) operating at various part-load conditions (e.g., 20 to 80 percent design capacity). Interestingly, the analysis indicated that the operating costs of a $600 \mathrm{icfm}$ unit operating at a low part load capacity (e.g., 40 percent or $240 \mathrm{icfm}$ output) had annual operating costs comparable to a $490 \mathrm{icfm}$ unit delivering the same quantity of air (e.g., $240 \mathrm{icfm}$ or 60 percent of this unit's design capacity). This was due to the performance characteristics of the two units-the larger unit actually had a better brake specific fuel consumption over most of the air delivery range.

As a result of this uncertainty, it was decided to request quotes for two different capacity NGEDACs - a $450 \mathrm{scfm}$ unit (equivalent to $600 \mathrm{icfm}$ ) and a $375 \mathrm{scfm}$ unit (equivalent to $490 \mathrm{icfm}$ ) - and make the final determination based on costeffectiveness. Researchers also specified that the NGEDAC should be capable of operating without external power sources - that is, all power required to drive auxiliary equipment (e.g., cooling fans) would be provided by the engine itself. Engine emissions were specified as that required to meet California's most stringent regulations. For the electric motor driven oil-free air compressor, it was estimated that $115 \mathrm{scfm}$ (about $150 \mathrm{icfm}$ ) capacity unit would be suitable. A receiver was also specified to meet short-duration capacity needs that might exceed 
the rated capacity of the electric motor driven oil-free air compressor. The RFQ for the compressors provides additional details on the specifications and is included in Appendix A.

\section{Analysis of Bids and Vendor Selection}

The RFQ was sent to two vendors in October 2001:

1. Cisco Air Systems, Inc. - Ingersoll-Rand Distributor (Sacramento, CA)

2. Accurate Air Engineering - Gardner Denver Distributor (Lodi, CA).

The NGEDAC bids were evaluated based on a comparison of capital costs as well as annual operating costs. Table 9 lists a summary of capital costs for the NGEDAC, where Option 1 refers to units that were proposed to meet a minimum of $450 \mathrm{scfm}$, and Option 2 refers to units that were proposed to meet the $375 \mathrm{scfm}$ threshold. Two quotes were received from Accurate Air (Gardner Denver compressor and Caterpillar engine packaged by Dearing Compressor, Ohio) for Option 1-an NGEDAC unit with the radiator fan driven by the engine, and a unit with the radiator fan driven by an electric motor. The unit with the motor can meet the scfm threshold, while the other one can not. While quotes were received for a number of different units from Cisco Air Systems (Ingersoll-Rand compressor and either Ford, MAN, or Waukesha engines packaged by Gascom of Denver, CO), only the NGEDAC packages with the MAN and Waukesha engines were considered. The Ford-powered unit, which is intended for relatively light duty, while suitable for the current situation at SIAD, was not considered as rugged as would be needed if SIAD went to significantly increased hours of operation. Therefore, it was not analyzed. Furthermore, the Waukesha and MAN powered NGEDACs were identical in price and similar in performance, so only the analysis for the MAN powered unit (Option 1) was undertaken. No Waukesha or MAN-powered units with catalytic converters were proposed for Option 2. The bids summarized in Table 9 include shipping costs.

Table 9. Summary of bids

\begin{tabular}{|l|c|c|}
\hline NGEDAC Capital Cost Summary & Cost & SCFM \\
\hline Gardner Denver (Caterpillar engine)- Option 1 & $\$ 167,649$ & 465 \\
\hline Gardner Denver (Caterpillar engine)- Option 2 & $\$ 125,295$ & 320 \\
\hline Gardner Denver (Caterpillar engine)- Option 2 with aux. /elec fan motor & $\$ 125,295$ & 375 \\
\hline Ingersoll Rand (MAN engine)- Option 1 & $\$ 135,940$ & 452 \\
\hline
\end{tabular}




\section{Annual Operating Costs}

Researchers performed the analysis of annual operating costs using two different compressed air load profiles designated as Operating Schedule A and Operating Schedule B. Operating Schedule A was based on the data collected during the monitoring performed in September 2001 extrapolated to a full year (2080 hours) of operation-a weighted average of $97 \mathrm{scfm}$ (a range of $60 \mathrm{scfm}-300$ scfm). Operating Schedule B represents higher compressed air usage-a weighted average of $250 \mathrm{scfm}$ (range of $100 \mathrm{scfm}-400 \mathrm{scfm}$ ).

Tables 10 and 11 list the results of the analysis. The Natural Gas Engine Driven Air Compressor Advisor software tool was used in calculating the annual operating costs.

\section{Comparison of Key Attributes and Vendor Selection}

A review of the information provided in the tables leads to the following observations.

\section{Efficiency}

The Ingersoll-Rand/MAN NGEDAC has the best efficiency as measured on a design scfm/MBtuh basis (448 scfm/MBtuh vs. $366 \mathrm{scfm} / \mathrm{MBtuh}$ ).

\section{Capital Cost}

The Ingersoll-Rand/MAN NGEDAC cost of $\$ 135,940$ is $\$ 31,709$ less than the comparable (Option 1) Gardner Denver/Caterpillar unit $(\$ 167,649)$ and $\$ 10,645$ more than the lower capacity (Option 2) Gardner Denver/Caterpillar unit $(\$ 125,295)$. For comparison purposes, the conceptual design estimate was $\$ 148,500$, including shipping.

\section{Maintenance Cost}

The 2-year maintenance cost for the Ingersoll-Rand/MAN NGEDAC of $\$ 3,795$ is $\$ 14,351$ less than the 2-year maintenance cost for the Gardner Denver/Caterpillar units $(\$ 18,146)$. For comparison purposes, the conceptual design estimate was $\$ 21,000$. 
Table 10. Annual operating costs under Schedule $A$. OPERATING SCHEDULE A - Light Load - Weight Average Output =

\section{PERFORMANCE ANALYSIS \\ Energy Use}

Gardner Denver (Caterpillar engine)- Option 2 without auxiliary electric fan motor (106 full load bhp)

with auxiliary electric fan motor (101 full load bhp)

Gardner Denver (Caterpillar engine)- Option 1 - 149 bhp

Ingersoll Rand (MAN engine) - Option 1 - 123 bhp

Peak Demand

Gardner Denver (Caterpillar engine)- Option 2

without auxiliary electric fan motor (106 full load bhp)

with auxiliary electric fan motor (101 full load bhp)

Gardner Denver (Caterpillar engine)- Option 1 - 149 bhp Ingersoll Rand (MAN engine) - Option 1 - 123 bhp COST ANALYSIS

Energy Operating Costs

Gardner Denver (Caterpillar engine)- Option 2

without auxiliary electric fan motor (106 full load bhp)

with auxiliary electric fan motor (101 full load bhp)

Gardner Denver (Caterpillar engine)- Option 1 - 149 bhp Ingersoll Rand (MAN engine) - Option 1 - 123 bhp

Peak Demand Costs

Gardner Denver (Caterpillar engine)- Option 2 without auxiliary electric fan motor (106 full load bhp) with auxiliary electric fan motor (101 full load bhp)

Gardner Denver (Caterpillar engine)- Option 1 - 149 bhp

Ingersoll Rand (MAN engine) - Option 1 - 123 bhp

Maintenance Costs

Gardner Denver (Caterpillar engine)- Option 2 without auxiliary electric fan motor (106 full load bhp) with auxiliary electric fan motor (101 full load bhp)

Gardner Denver (Caterpillar engine)- Option 1 - 149 bhp

Ingersoll Rand (MAN engine) - Option 1 - 123 bhp

Heat Recovery Costs

Gardner Denver (Caterpillar engine)- Option 2 without auxiliary electric fan motor (106 full load bhp) with auxiliary electric fan motor (101 full load bhp)

Gardner Denver (Caterpillar engine)- Option 1 - 149 bhp

Ingersoll Rand (MAN engine) - Option 1 - 123 bhp

Total Costs

Gardner Denver (Caterpillar engine)- Option 2 without auxiliary electric fan motor (106 full load bhp) with auxiliary electric fan motor (101 full load bhp)

Gardner Denver (Caterpillar engine)- Option 1 - 149 bhp

Ingersoll Rand (MAN engine) - Option 1 - 123 bhp

(1) @ 70\% of full load.

(2) @ $90 \%$ of full load.

(3) @80\% of full load.

(4) @70\% of full load.

(5) @70\% of full load.

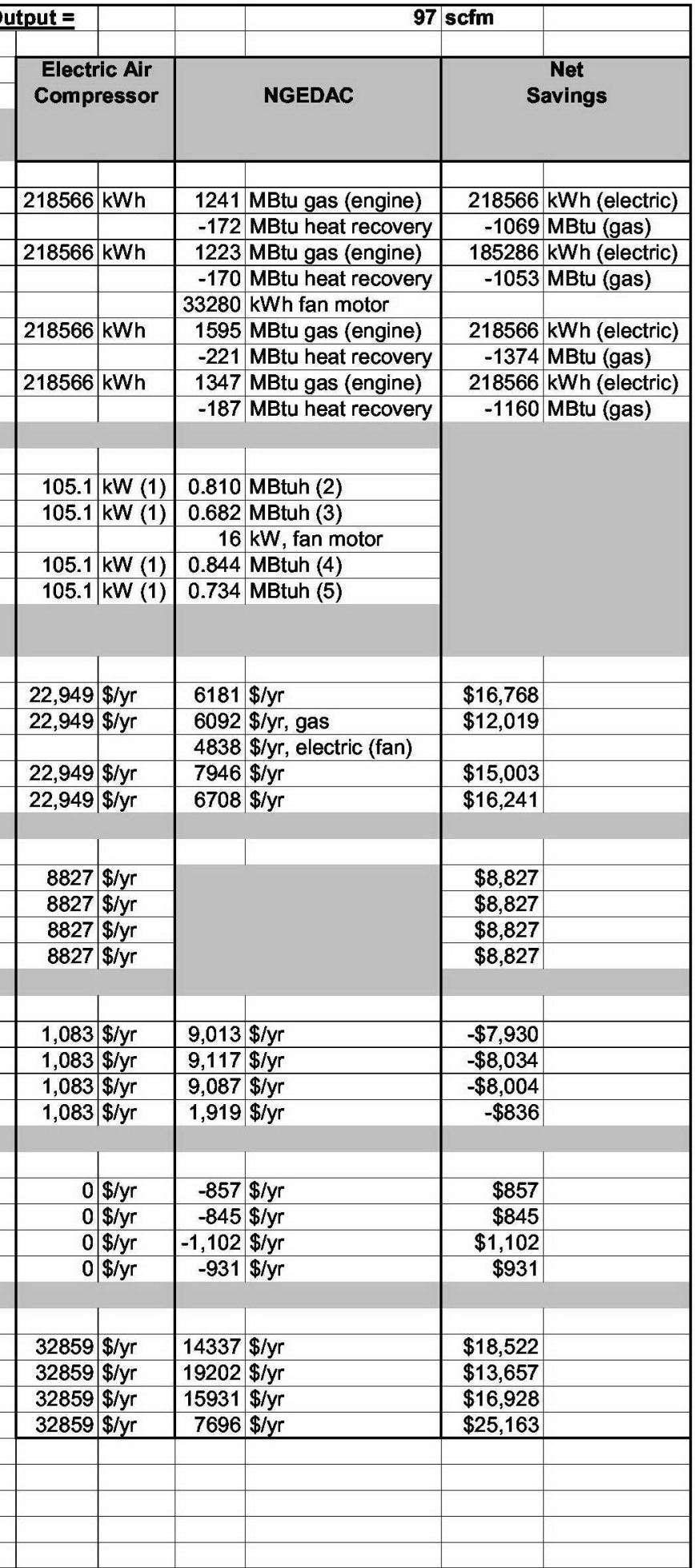


Table 11. Annual operating costs under Schedule B.

\begin{tabular}{|c|c|c|c|c|c|c|}
\hline \multicolumn{3}{|c|}{ OPERATING SCHEDULE B - Heavier Load - Weight Average Output = } & \multicolumn{2}{|c|}{$250 \mathrm{scfm}$} & & \\
\hline & \multicolumn{2}{|c|}{$\begin{array}{l}\text { Electric Air } \\
\text { Compressor }\end{array}$} & \multirow{2}{*}{\multicolumn{2}{|c|}{ NGEDAC }} & \multicolumn{2}{|c|}{$\begin{array}{c}\text { Net } \\
\text { Savings }\end{array}$} \\
\hline \multicolumn{5}{|l|}{$\begin{array}{l}\text { PERFORMANCE ANALYSIS } \\
\text { Enerov Use }\end{array}$} & & \\
\hline $\begin{array}{l}\text { Energy Use } \\
\text { Gardner Denver (Caterpillar engine)- Option } 2\end{array}$ & & & & & & \\
\hline \multirow[t]{2}{*}{ without auxiliary electric fan motor (106 full load bhp) } & \multicolumn{2}{|c|}{219256 kWh } & 1781 & MBtu gas (engine) & \multicolumn{2}{|c|}{$219256 \mathrm{kWh}$ (electric) } \\
\hline & & & -247 & MBtu heat recovery & \multicolumn{2}{|c|}{-1534 MBtu (gas) } \\
\hline \multirow[t]{3}{*}{ with auxiliary electric fan motor (101 full load bhp) } & \multicolumn{2}{|c|}{219256 kWh } & 1475 & MBtu gas (engine) & \multicolumn{2}{|c|}{$185976 \mathrm{kWh}$ (electric) } \\
\hline & & & -205 & MBtu heat recovery & -1270 & MBtu (gas) \\
\hline & & & 33280 & kWh fan motor & & \\
\hline \multirow[t]{2}{*}{ Gardner Denver (Caterpillar engine)- Option 1 - 149 bhp } & \multicolumn{2}{|c|}{219256 kWh } & 1860 & MBtu gas (engine) & \multicolumn{2}{|c|}{219256 kWh (electric) } \\
\hline & & & -258 & MBtu heat recovery & -1602 & MBtu (gas) \\
\hline Ingersoll Rand (MAN engine) - Option 1 - 123 bhp & 219256 & $\mathrm{kWh}$ & 1608 & MBtu gas (engine) & 219256 & kWh (electric) \\
\hline & & & -223 & MBtu heat recovery & -1385 & MBtu (gas) \\
\hline Peak Demand & & & & & & \\
\hline Gardner Denver (Caterpillar engine)- Option 2 & & & & & & \\
\hline without auxiliary electric fan motor (106 full load bhp) & 108.4 & $\mathrm{~kW}(1)$ & 0.920 & MBtuh (2) & & \\
\hline with auxiliary electric fan motor (101 full load bhp) & 108.4 & $\mathrm{~kW}(1)$ & 0.853 & MBtuh (3) & & \\
\hline & & & 16 & $\mathrm{~kW}$, fan motor & & \\
\hline Gardner Denver (Caterpillar engine)- Option 1 - 149 bhp & 108.4 & $k W(1)$ & 1.112 & MBtuh (4) & & \\
\hline Ingersoll Rand (MAN engine) - Option 1 - 123 bhp & 108.4 & $\mathrm{~kW}(1)$ & 0.909 & MBtuh (5) & & \\
\hline COST ANALYSIS & & & & & & \\
\hline Energy Operating Costs & & & & & & \\
\hline Gardner Denver (Caterpillar engine)- Option 2 & & & & & & \\
\hline without auxiliary electric fan motor (106 full load bhp) & 23022 & $\$ / y r$ & 8871 & $\$ / y r$ & $\$ 14,151$ & \\
\hline with auxiliary electric fan motor (101 full load bhp) & 23022 & $\$ / y r$ & 7348 & $\$ / y r$, gas & $\$ 10,836$ & \\
\hline & & & 4838 & $\$ / y r$, electric (fan) & & \\
\hline Gardner Denver (Caterpillar engine)- Option 1 - 149 bhp & 23022 & $\$ / y r$ & 9264 & $\$ / y r$ & $\$ 13,758$ & \\
\hline Ingersoll Rand (MAN engine) - Option 1 - 123 bhp & 23022 & $\$ / y r$ & 8011 & $\$ / y r$ & $\$ 15,011$ & \\
\hline Peak Demand Costs & & & & & & \\
\hline Gardner Denver (Caterpillar engine)- Option 2 & & & & & & \\
\hline without auxiliary electric fan motor (106 full load bhp) & 9106 & $\$ / y r$ & & & $\$ 9,106$ & \\
\hline with auxiliary electric fan motor (101 full load bhp) & 9106 & $\$ / y r$ & & & $\$ 9,106$ & \\
\hline Gardner Denver (Caterpillar engine)- Option 1 - 149 bhp & 9106 & $\$ / y r$ & & & $\$ 9,106$ & \\
\hline Ingersoll Rand (MAN engine) - Option 1 - 123 bhp & 9106 & $\$ / y r$ & & & $\$ 9,106$ & \\
\hline Maintenance Costs & & & & & & \\
\hline Gardner Denver (Caterpillar engine)- Option 2 & & & & & & \\
\hline without auxiliary electric fan motor (106 full load bhp) & 1,086 & $\$ / y r$ & 9,053 & $\$ / y r$ & $-\$ 7,967$ & \\
\hline with auxiliary electric fan motor (101 full load bhp) & 1,086 & $\$ / y r$ & 9,114 & $\$ / y r$ & $-\$ 8,028$ & \\
\hline Gardner Denver (Caterpillar engine)- Option 1 - 149 bhp & 1,086 & $\$ / y r$ & 9,024 & $\$ / y r$ & $-\$ 7,938$ & \\
\hline Ingersoll Rand (MAN engine) - Option 1 - 123 bhp & 1,086 & $\$ / y r$ & 1,939 & $\$ / y r$ & $-\$ 853$ & \\
\hline Heat Recovery Costs & & & & & & \\
\hline Gardner Denver (Caterpillar engine)- Option 2 & & & & & & \\
\hline without auxiliary electric fan motor (106 full load bhp) & & $\$ / y r$ & $-1,231$ & $\$ / y r$ & $\$ 1,231$ & \\
\hline with auxiliary electric fan motor (101 full load bhp) & & $\$ / y r$ & $-1,019$ & $\$ / y r$ & $\$ 1,019$ & \\
\hline Gardner Denver (Caterpillar engine)- Option 1 - 149 bhp & & $\$ / y r$ & $-1,285$ & $\$ / y r$ & $\$ 1,285$ & \\
\hline Ingersoll Rand (MAN engine) - Option 1 - 123 bhp & & $\$ / y r$ & $-1,111$ & $\$ / y r$ & $\$ 1,111$ & \\
\hline Total Costs & & & & & & \\
\hline Gardner Denver (Caterpillar engine)- Option 2 & & & & & & \\
\hline without auxiliary electric fan motor (106 full load bhp) & 33214 & $\$ / y r$ & 16693 & $\$ / y r$ & $\$ 16,521$ & \\
\hline with auxiliary electric fan motor (101 full load bhp) & 33214 & $\$ / y r$ & 20281 & $\$ / y r$ & $\$ 12,933$ & \\
\hline Gardner Denver (Caterpillar engine)- Option 1 - 149 bhp & 33214 & $\$ / y r$ & 17003 & $\$ / y r$ & $\$ 16,211$ & \\
\hline Ingersoll Rand (MAN engine) - Option 1 - 123 bhp & 33214 & $\$ / y r$ & 8839 & $\$ / y r$ & $\$ 24,375$ & \\
\hline (1) @90\% of full load. & & & & & & \\
\hline (2)@100\% of full load. & & & & & & \\
\hline (3) @100\% of full load. & & & & & & \\
\hline (4) @90\% of full load. & & & & & & \\
\hline (5) @90\% of full load. & & & & & & \\
\hline
\end{tabular}




\section{Heat Recovery}

The Ingersoll-Rand/MAN NGEDAC and the Gardner Denver/Caterpillar NGEDAC have comparable heat recovery performance.

\section{Economics of NGEDAC Options}

Tables 12 and 13 list the economics of NGEDAC options under Operating Schedules $\mathrm{A}$ and $\mathrm{B}$, respectively.

The economic analysis clearly favored the Cisco Systems bid to provide the Ingersoll-Rand/MAN NGEDAC. While the smaller capacity (Option 1) Gardner Denver/Caterpillar NGEDAC unit with an electric motor to provide auxiliary power had a lower capital cost, it provided less air and had higher projected energy operating costs and maintenance costs. Furthermore, since Cisco Air Systems had claimed they were able to deliver the NGEDAC within 6 weeks, as opposed to Accurate Air Engineering's 12 weeks, the Cisco Systems bid was recommended for award. This was agreed-upon by CERL and SIAD.

With regard to the electric motor driven oil-free air compressor, the Accurate Air bid of $\$ 42,173$ (Gardner Denver unit) was significantly lower than the Cisco Air bid of $\$ 54,450$, (Ingersoll-Rand unit) therefore this award went to Accurate Air. The conceptual design estimate was $\$ 48,400$, including shipping.

Table 12. Economics of NGEDAC options under operating schedule A.

\begin{tabular}{|l|r|r|r|}
\hline NGEDAC Option & $\begin{array}{c}\text { Payback } \\
\text { (years) }\end{array}$ & \multicolumn{1}{|c|}{$\begin{array}{c}\text { NPV } \\
\text { (\$) }\end{array}$} & $\begin{array}{c}\text { IRR } \\
(\% / y r)\end{array}$ \\
\hline Gardner Denver (Caterpillar engine)- Option 2 & 6.76 & 93585 & 11.6 \\
\hline without auxiliary electric fan motor (106 full load bhp) & 9.17 & 31813 & 6.6 \\
\hline with auxiliary electric fan motor (101 full load bhp) & 9.90 & 29163 & 5.7 \\
\hline Gardner Denver (Caterpillar engine)- Option 1 - 149 bhp & 5.40 & 175637 & $\mathbf{1 6 . 4}$ \\
\hline Ingersoll-Rand (MAN engine) - Option 1 - 123 bhp &
\end{tabular}

Table 13. Economics of NGEDAC options under Operating Schedule B.

\begin{tabular}{|l|r|r|r|}
\hline NGEDAC Option & $\begin{array}{c}\text { Payback } \\
\text { (years) }\end{array}$ & $\begin{array}{c}\text { NPV } \\
\text { (\$) }\end{array}$ & $\begin{array}{c}\text { IRR } \\
\text { (\%/yr) }\end{array}$ \\
\hline Gardner Denver (Caterpillar engine)- Option 2 & 7.58 & 65484 & 9.5 \\
\hline without auxiliary electric fan motor (106 full load bhp) & 9.69 & 21389 & 5.7 \\
\hline with auxiliary electric fan motor (101 full load bhp) & 10.34 & 18843 & 5 \\
\hline Gardner Denver (Caterpillar engine)- Option 1 - 149 bhp & 5.58 & 164325 & 15.7 \\
\hline Ingersoll-Rand (MAN engine) - Option 1 - 123 bhp & &
\end{tabular}




\section{Installation Contractor Selection}

An RFQ was issued in November 2001 to three vendors for the purpose of installing the NGEDAC and the electric motor driven air compressor. The request consisted of the scope of work, a basis of design document, and a set of the design drawings (Appendix B includes the RFQ). The design documents were at the 65 percent completion stage at the time of their release and consisted primarily of the mechanical system and plumbing drawings. Drawings that were not available included architectural and structural details, detailed specifications, electrical details and electrical controls, and fire protection. Only one response was received, which was considerably higher than the design estimate. One of the reasons for the high quote was the lack of details on a number of the items, so the contractor's cost assumptions included significant contingencies. To get a more favorable bid, the RFQ was re-issued in late December, with a nearly complete set of design drawings, and provided more detailed specifications. The RFQ was sent to three vendors and shortly thereafter, to a fourth. During this same time, it was decided to subcontract and pre-purchase several system components including the slab/concrete work, the heat recovery heat exchanger, the electrical control panel for the NGEDAC, the water flow meter for the heat recovery loop, and the natural gas flow meter. These were items could take 1 to 3 weeks to order. Consequently, it was important to ensure that-once the installation contractor was selected-delays due to equipment not available "off-theshelf" could be avoided. Three bidders ultimately responded to the RFQ, and after several iterations, provided their best and final offers.

The conceptual design estimate for the installation was $\$ 72,000$ for the NGEDAC and $\$ 10,300$ for the electric motor driven oil-free air compressor. Based on this information L.A. Perks Plumbing \& Heating of Sparks, NV was recommended for selection as the installation contractor for both compressors. Although Frank M. Booth's bid was the lowest for the electric motor-driven oilfree air compressor, this bid did not include all of the required items. CERL and SIAD agreed with the recommendation and the award was made to L.A. Perks Plumbing \& Heating in early February 2002. It was agreed that the NGEDAC would be installed first, over a 2 -week period, followed by the electric-motor driven oil-free air compressor.

\section{Construction Process}

The construction process to install the Gascom GCM635 natural gas compressor (139 hp) and the Gardner Denver TA-40 oil-free electric compressor (40 hp) followed the Basis of Design (BOD) scope. The construction activities comprise five engineering categories: 

1. Structural
2. Architectural
3. Electrical
4. Mechanical and plumbing
5. Controls.

\section{Structural}

Due to SIAD's location in a seismic 3 area and the age of the existing concrete floor slab, new bases (pads) were provided for each of the two compressors. This was accomplished by saw-cutting the slab, removing the concrete, asphalt, and earth underneath to accommodate the dimensions of the new pads and foundation footers. Reinforced concrete 12-in. deep and 8-in. wider than each compressor footprint was poured, with the surface leveled to be flush with the remaining floor slab (Figure 7).

The existing pad was also upgraded to include a drainage system for various water streams generated by the NGEDAC and motor driven oil-free air compressors. This involved cutting a 4 -in. wide trench for each of the discharge lines and digging a pit for the sump pump. The trenches and sump pit were later widened to enable proper installation. This was due to the selection of a different model sump pump (larger dimensions) than originally specified and the need to provide sufficient room for workers to lay the drain pipe. The specified funnel drains were replaced with standard floor drains due to the small clearance between the drain pipe termination point and the floor.

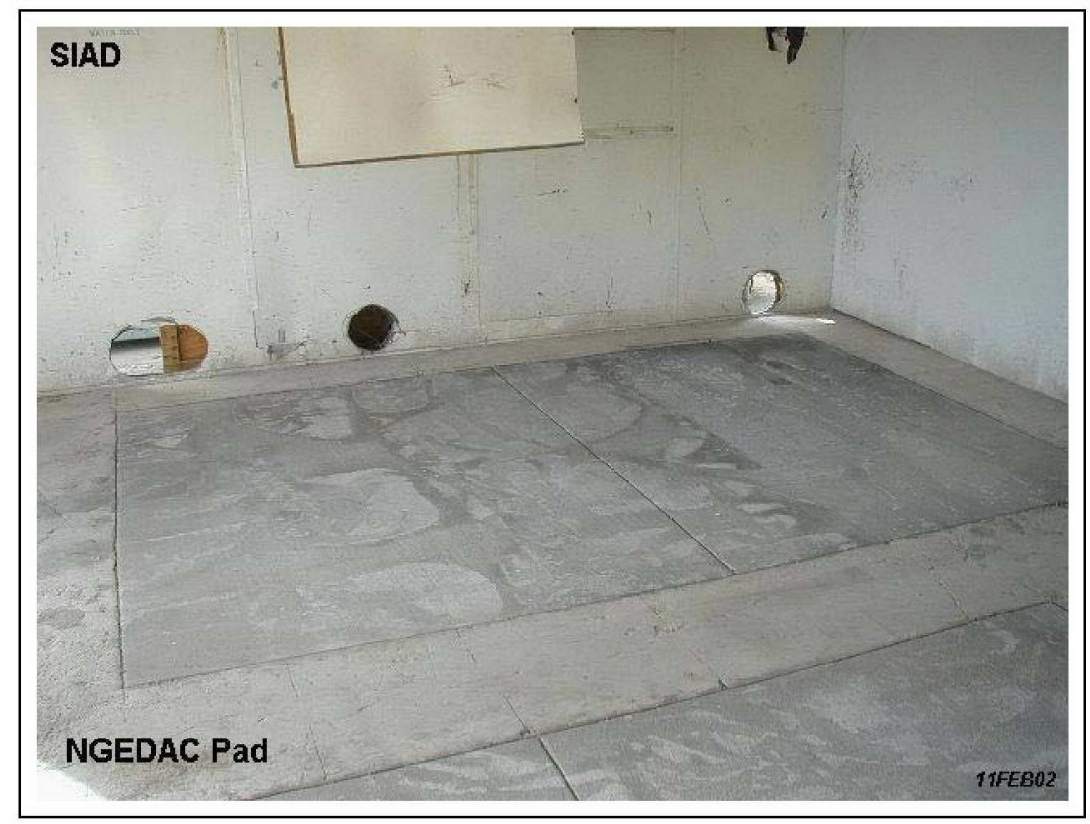

Figure 7. Reinforced compressor pads. 
Table 14. Equipment serviced by electrical installation.

\begin{tabular}{|l|l|}
\hline Voltage & Equipment \\
\hline 480VAC, 3ph & 1. Oil-Free Compressor, 40hp \\
\hline & 1. Heat Recovery Pump \\
\hline & 2. NGEDAC lighting \\
\hline 208Y/120VAC, 3ph & 3. Oil-free Dryer \\
\hline & 4. Control Panel \\
\hline & 5. Monitoring Panel \\
\hline & 6. Sump Pump \\
\hline & 7. Service Outlet \\
\hline
\end{tabular}

\section{Architectural}

The fixed west wall of the compressor room was removed to facilitate the installation of the new compressors. New steel double-doors for room entrance and equipment removal were installed, including a latch handle and locking mechanism.

For adequate air cooling of the compressors, intake and exhaust louvers were installed in the north and south walls. Metal framing was used to provide watertight installation.

\section{Electrical}

Electrical installation provided electrical service to the equipment listed in Table 14. Electrical service construction included upgrading the $480 \mathrm{~V}$ wireway panel and the installation of $480 \mathrm{~V}$ and $208 \mathrm{~V}$ conduit runs, disconnect panels, circuit breakers and circuit breaker panels. Approximately $179 \mathrm{ft}$ of $480 \mathrm{~V}$ service and $91 \mathrm{ft}$ of $208 \mathrm{~V}$ service were installed.

\section{Mechanical and Plumbing}

The Mechanical \& Plumbing activity constituted the major part of the construction effort, which saw the installation of HVAC ducting and dry and wet piping service.

HVAC

The HVAC system provides air cooling and heat rejection for the two compressors. Three $4 \times 6 \mathrm{ft}$ intake louvers were installed on the north wall to provide a maximum of $28,500 \mathrm{cfm}$ of fresh air cooling for both compressors. The intake 
louvers are equipped with two-position damper actuators. A single $5 \mathrm{x} 5 \mathrm{ft}$ exhaust louver was installed on the south wall to provide a maximum of $20,000 \mathrm{cfm}$ of heat rejection for the NGEDAC compressor (Figure 8). Sheet metal ducting equipped with modulating re-circulating and exhaust dampers was installed to route the NGEDAC cooling exhaust air to the exhaust louver. Face and bypass dampers equipped with modulating re-circulating and exhaust dampers were interfaced with the existing roof exhaust duct work to route the oil-free cooling exhaust to the atmosphere. All damper actuators interface with the control panel to control the plenum air space temperature. The room includes a new backup steam heated forced air heater with thermostat to maintain adequate room temperature if the compressors are nonoperational during the winter season (Figure 9).

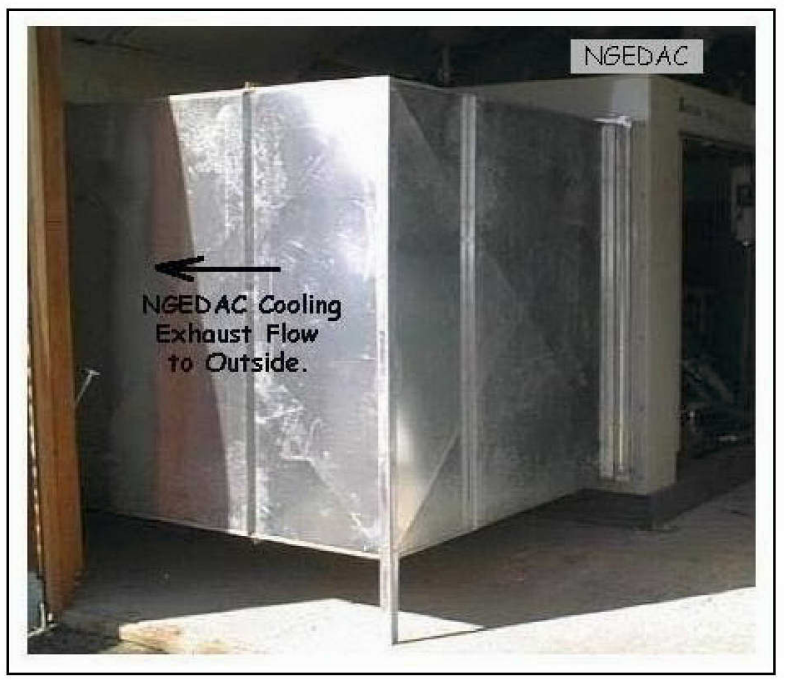

Figure 8. NGEDAC cooling exhaust.

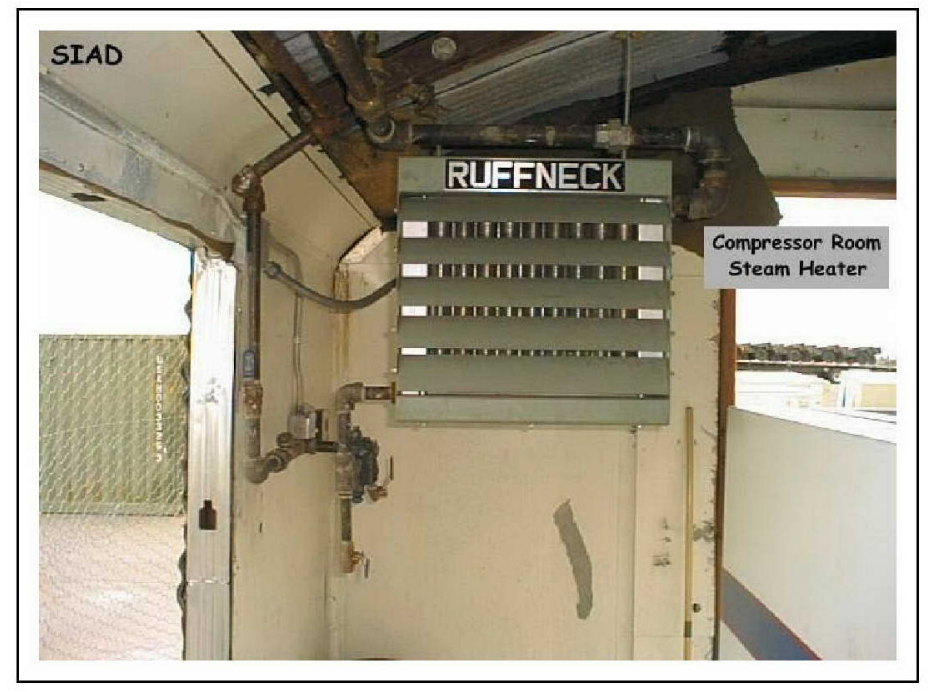

Figure 9. Compressor room steam heater. 


\section{Natural Gas System}

The existing natural gas system delivered gas to two make-up air handlers in Bldg 210. Modifications were made to the existing gas manifold and regulator components to accommodate gas service to the NGEDAC. The pressure regulation station was upgraded to deliver 5 psig service to the NGEDAC (Figure 10). Due to the increased pressure, a pressure reducer was added to the manifold circuit for proper supply pressure to the Make-up Air-handler Units (Figure 11). Approximately $207 \mathrm{ft}$ of 1 1/2-in. ASTM A53 black steel piping was installed from the manifold station to the NGEDAC. For monitoring purposes, a rotary gas meter was installed near the NGEDAC (Figure 12). Final hook-up was delayed by about $2 \frac{1}{2}$ weeks when it was discovered that an overpressure safety valve had to be reconfigured to a lower pressure setting. This required ordering parts for the valve, and scheduling with the gas utility's contractor for installation.

\section{Compressor Inlet Air System}

Approximately $81 \mathrm{ft}$ of schedule 40 PVC piping was installed to deliver fresh air to the: (1) existing electric-driven compressor, (2) NGEDAC and (3) electric motor driven oil-free air compressor. Prevailing winds at the base are typically from the east. To minimize contaminates entering the air system, the inlet gooseneck pipe was installed upwind and $50 \mathrm{ft}$ from the NGEDAC muffler. Figure 13 shows the inlet goose-neck on the roof of Bldg 210. Figure 14 shows the piping roof penetration and feed to the compressor rooms.

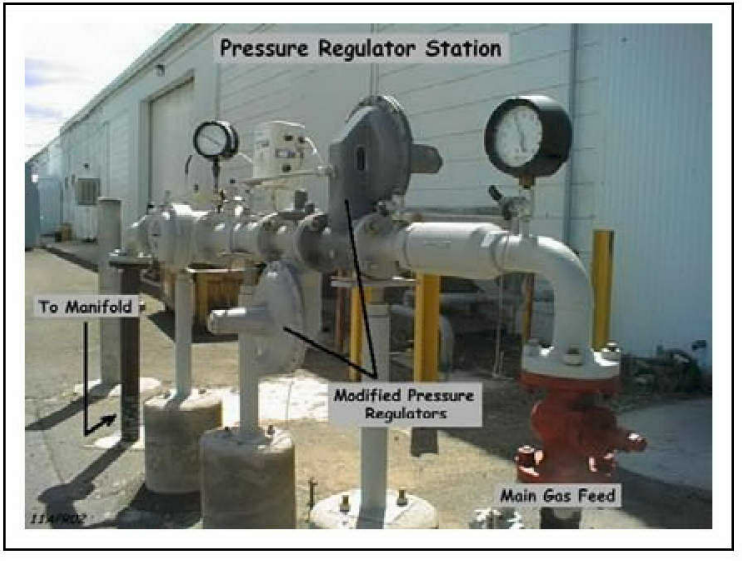

Figure 10. Natural gas pressure regulator station.

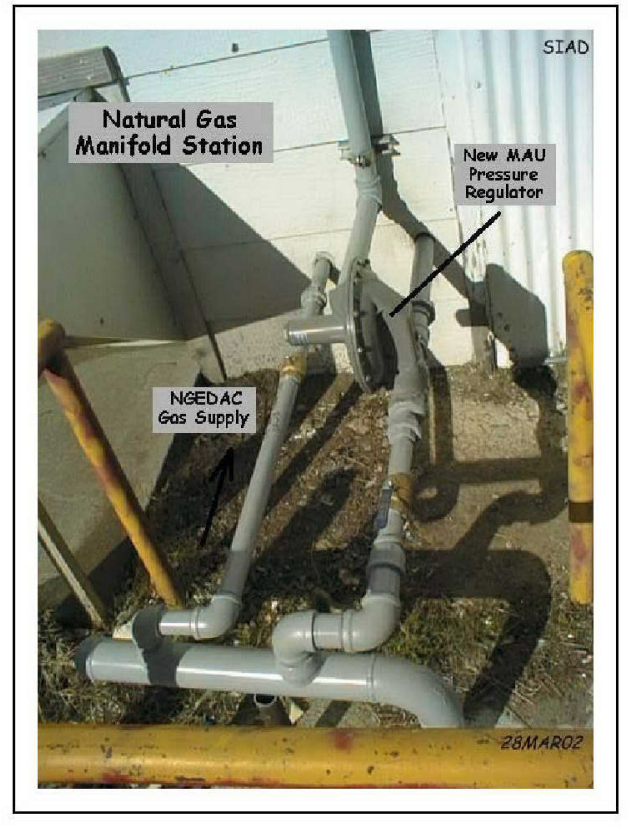

Figure 11. Natural gas manifold station. 


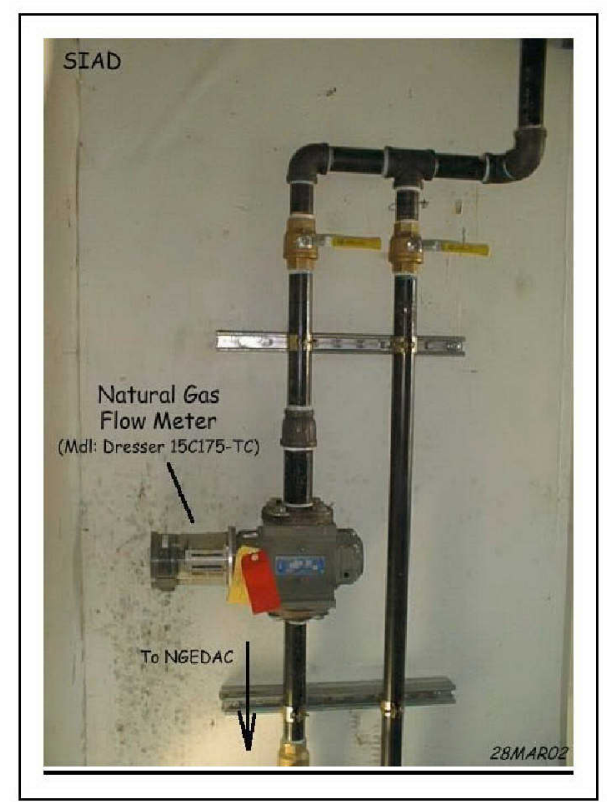

Figure 12. Natural gas flow meter.

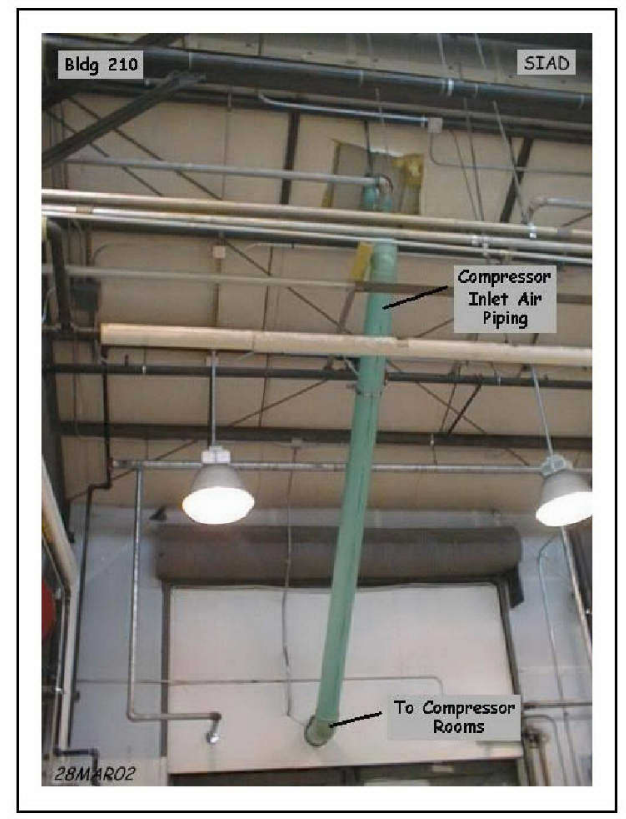

Figure 14. Compressor intake air ductinside Bldg 210.

\section{Compressed Air System}

The existing compressed air system consisted of a single compressor to provide both process air and breathing air. The new compressed air system includes three compressors configured in a parallel design that permits high operational flexibility, allowing: (1) the existing electric compressor to be used as backup for 
process air, (2) the NGEDAC to function as the primary process air compressor, and (3) the electric motor driven oil-free air compressor to serve as the breathing air compressor. Compressed air service construction included the installation of copper piping, check valves, and blocking valves. Approximately $150 \mathrm{ft}$ of compressed air supply piping was installed. The output of the oil-free compressor is treated by the existing Nomonox air purifiers (Figure 15) and includes the addition of a 240 gal receiver tank to meet surge demands and an air dryer to control moisture (Figure 16). For monitoring purposes, a mass flow meter and temperature sensor were installed in the process line between the receiver tank and the dryer.

\section{Exhaust System}

The NGEDAC engine exhaust is piped through the compressor room roof to the combination muffler/catalytic converter via 3-in. stainless steel tubing. The muffler assembly was externally mounted to the roof of the compressor room via steel bracing and banding, welded to the existing roof frame and weatherproofed for water tightness (Figure 17).

\section{Heat Recovery System}

Construction of the heat recovery system included retrofitting the existing makeup air unit (MAU-1) with a 100 x 42-in. aluminum/copper two row coil (Figure 18), installing a circulation pump, air separator, expansion tank, propylene glycol pot feeder and make-up water connection. Approximately $418 \mathrm{ft}$ of insulated copper piping was installed. Approximately 45 gal of propylene glycol was mixed with about 120 gal of water (40 percent mixture) to provide freeze protection to $6^{\circ} \mathrm{F}$. Propylene glycol was specified since it is a nontoxic anti-freeze. The pot feeder provides a means of adding more propylene glycol as needed. For monitoring purposes, temperature sensors (Figure 19) and a water flow meter (Figure 20) were installed in the heat recovery lines before and after the NGEDAC. Thermowells were used to enable insertion or removal of the temperature sensors without the need to shutdown the heat recovery system.

\section{Make-up Water System}

Approximately $50 \mathrm{ft}$ of 1 -in. copper piping was installed to deliver potable water to the oil-free compressor and the heat recovery loop. Water is used as a substitute for oil to lubricate the oil-free compressor. To prevent industrial water (e.g., heat recovery water/propylene glycol mix) from possibly contaminating the potable water supply, a backflow preventer was installed (Figure 21). 


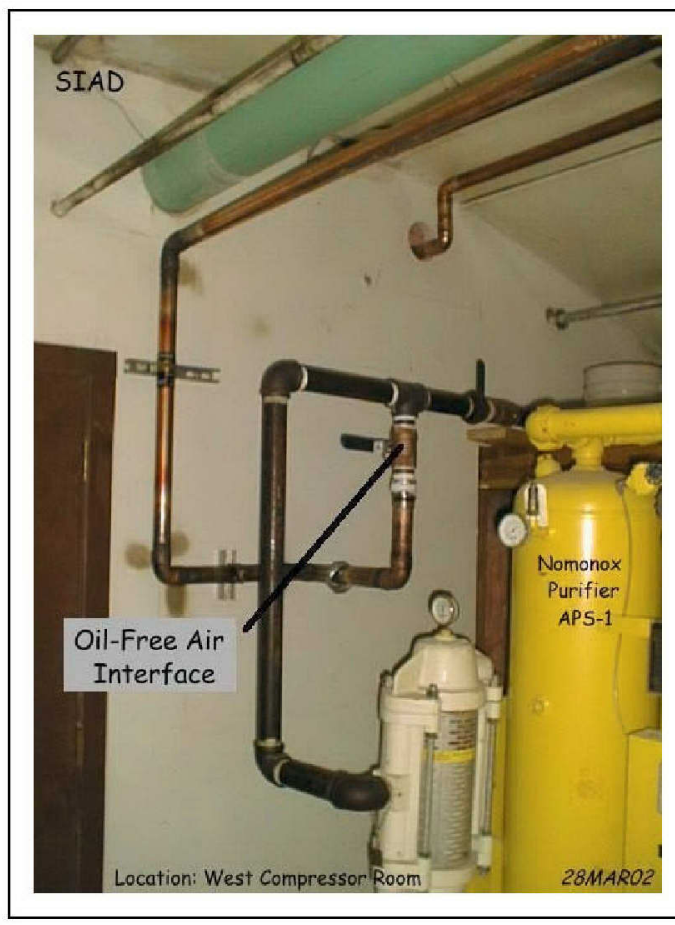

Figure 15. Oil-free compressed air interface to Nomonox.

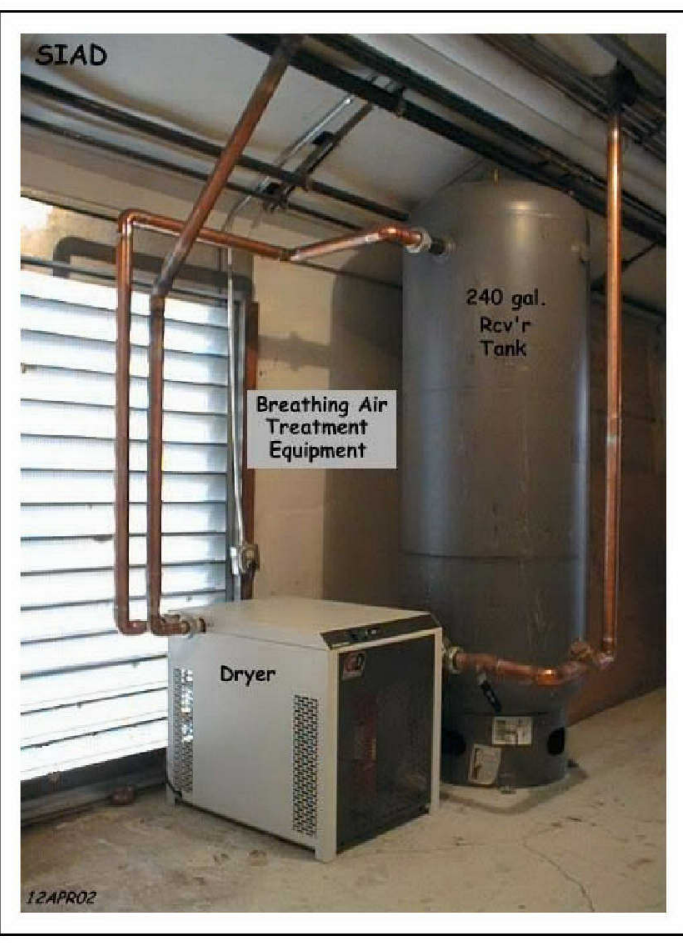

Figure 16. Oil-free compressor receiver and dryer.

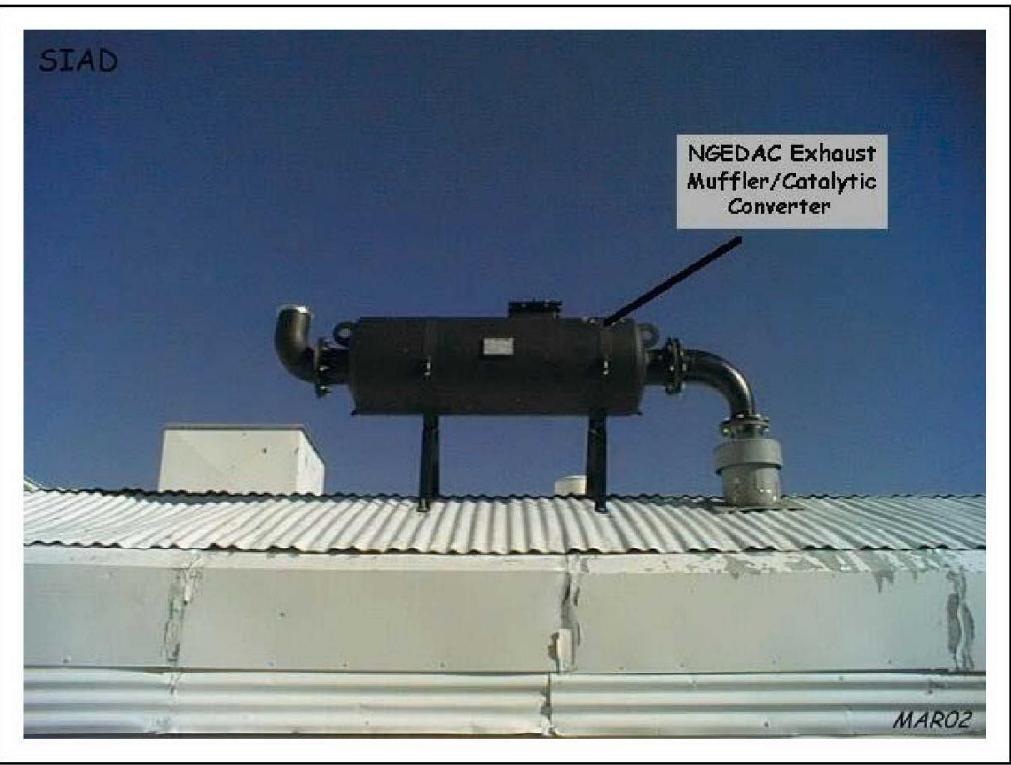

Figure 17. NGEDAC exhaust muffler/catalytic converter. 


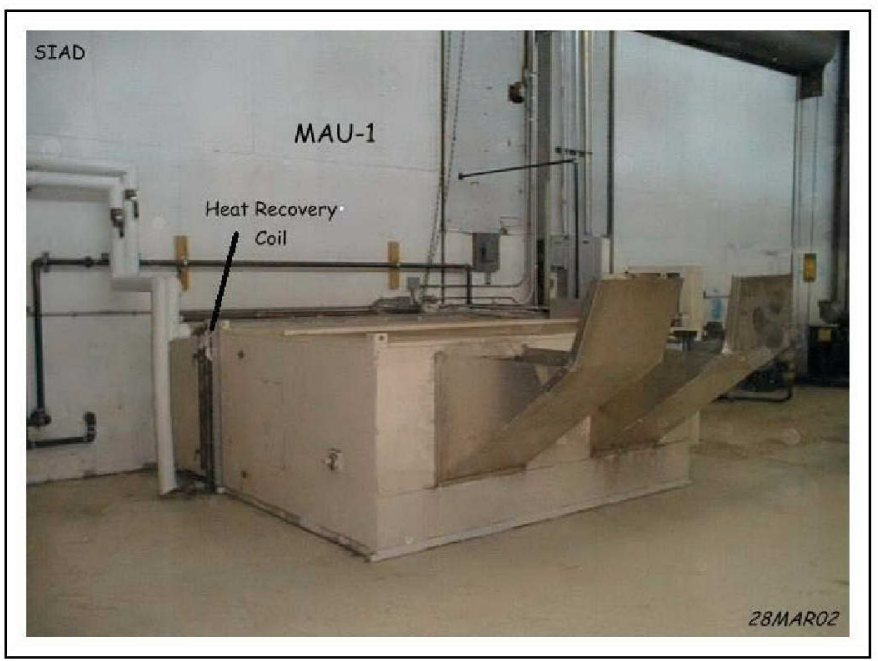

Figure 18. MAU-1 heat recovery coil.

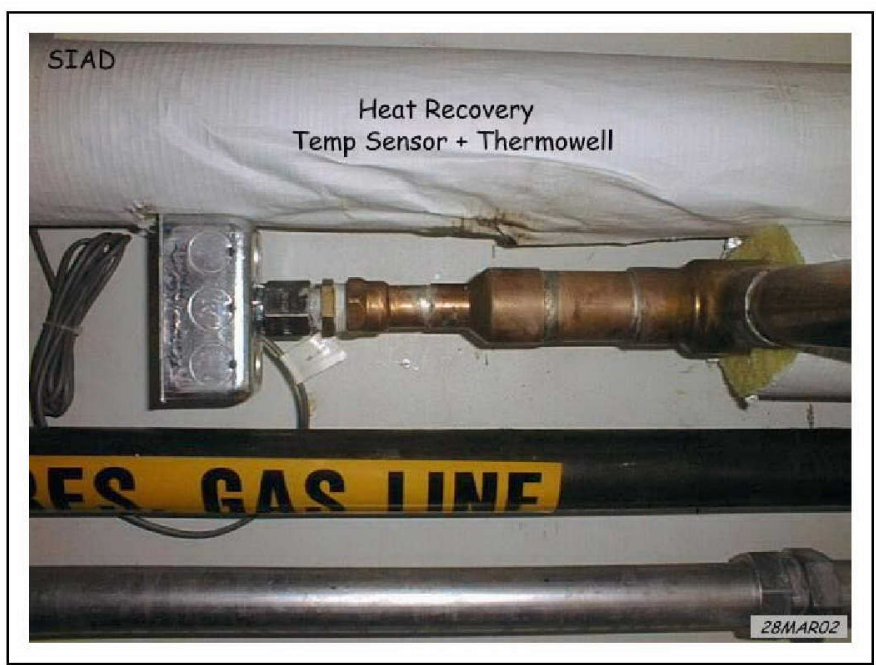

Figure 19. Heat recovery temperature sensor/thermowell.

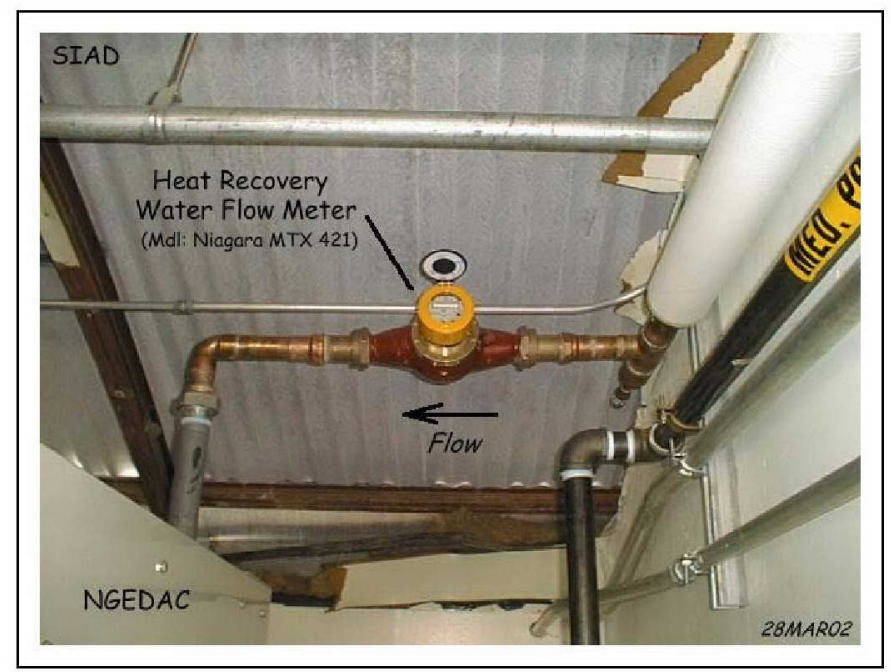

Figure 20. Heat recovery water flow meter. 


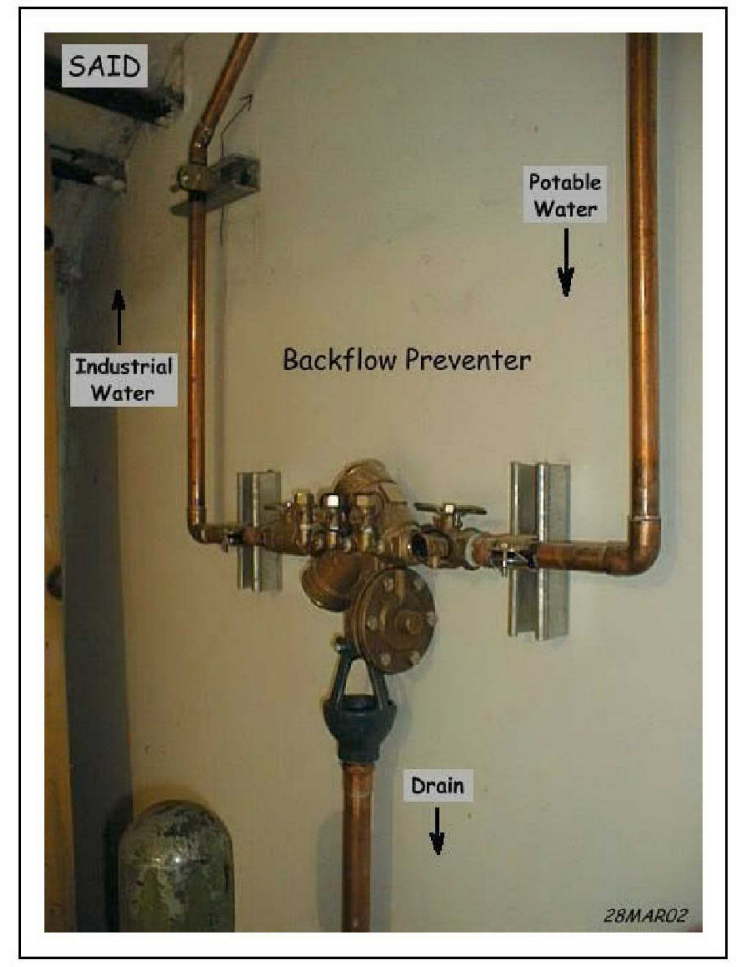

Figure 21. Make-up water backflow preventer.

\section{Sanitary Waste System}

Construction of the sanitary waste system included installation of two drains, a sump pump, and approximately $50 \mathrm{ft}$ of 2 -in. underground piping. The sump pump discharge piping was initially tied into the utility sink drain piping outside the compressor room in Bldg 210 (Figure 22). This was later modified to tie directly into the sewer line.

\section{Controls}

Construction of the control system consisted of installing the control panel and conduits runs to: (1) MAU-1, (2) existing electric compressor, (3) 300-gal process air receiver tank, (4) fresh air dampers, (5) NGEDAC mix air dampers, (6) oilfree compressor mix air dampers, (7) NGEDAC run enable and (8) heat recovery circulation pump. The function of the automatic control system is three-fold: (1) start-up of the back-up electric compressor when the NGEDAC compressor fails or is out-of-service, (2) heat recovery pump start when the MAU is running and outside air temperature permits, and (3) control of room intake and exhaust dampers to maintain space temperature. The control system also permits manual operation of the back-up electric compressor, heat recovery pump and dampers. Figure 23 shows the installation of the control panel. 


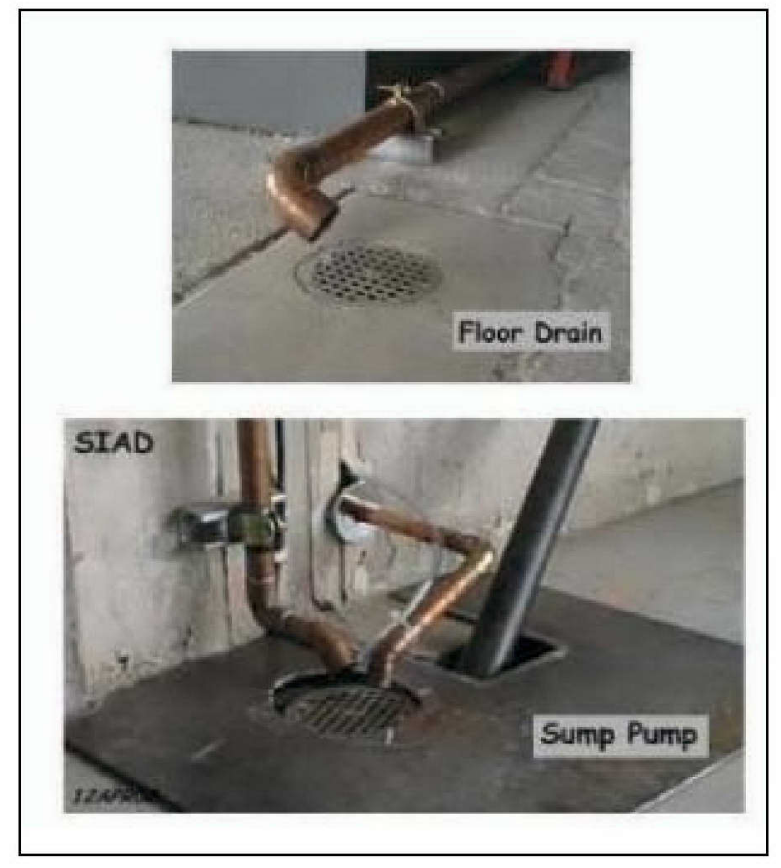

Figure 22. Floor drain and sump pump.

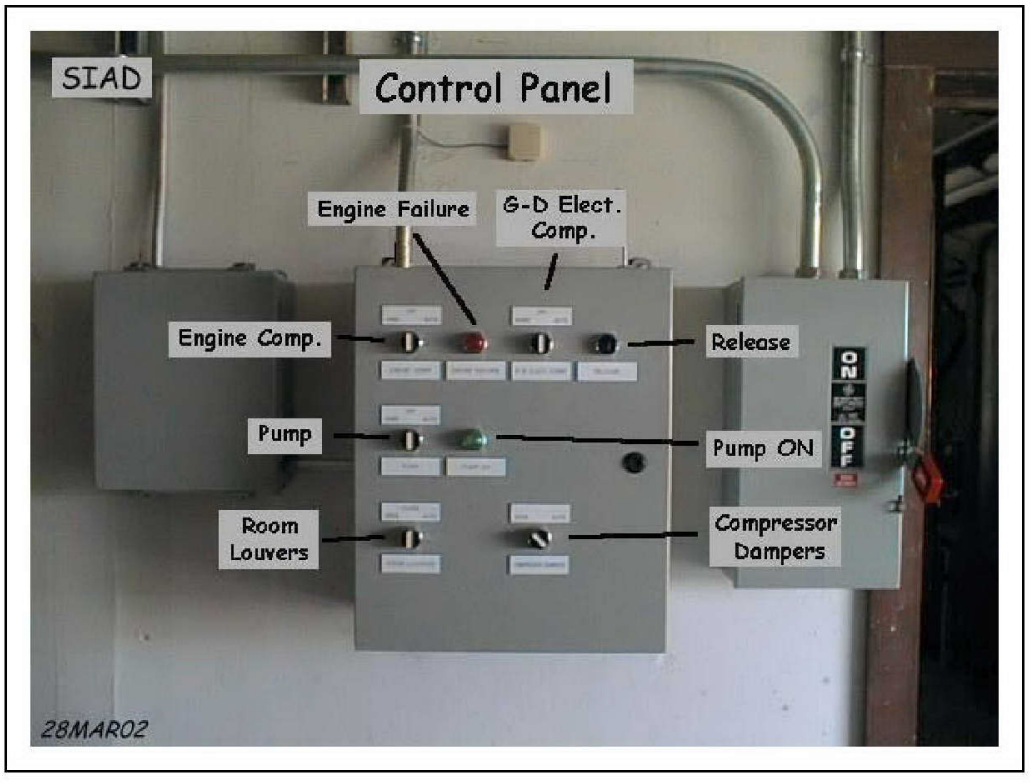

Figure 23. Compressor system control panel.

\section{Compressor Installation}

The NGEDAC compressor was installed at the south-end of the compressor room and the oil-free compressor was installed at the north-end. Adequate spacing of approximately 2 to $3 \mathrm{ft}$ surrounds each compressor permitting easy maintenance and service (Figures $24-26$ ). 


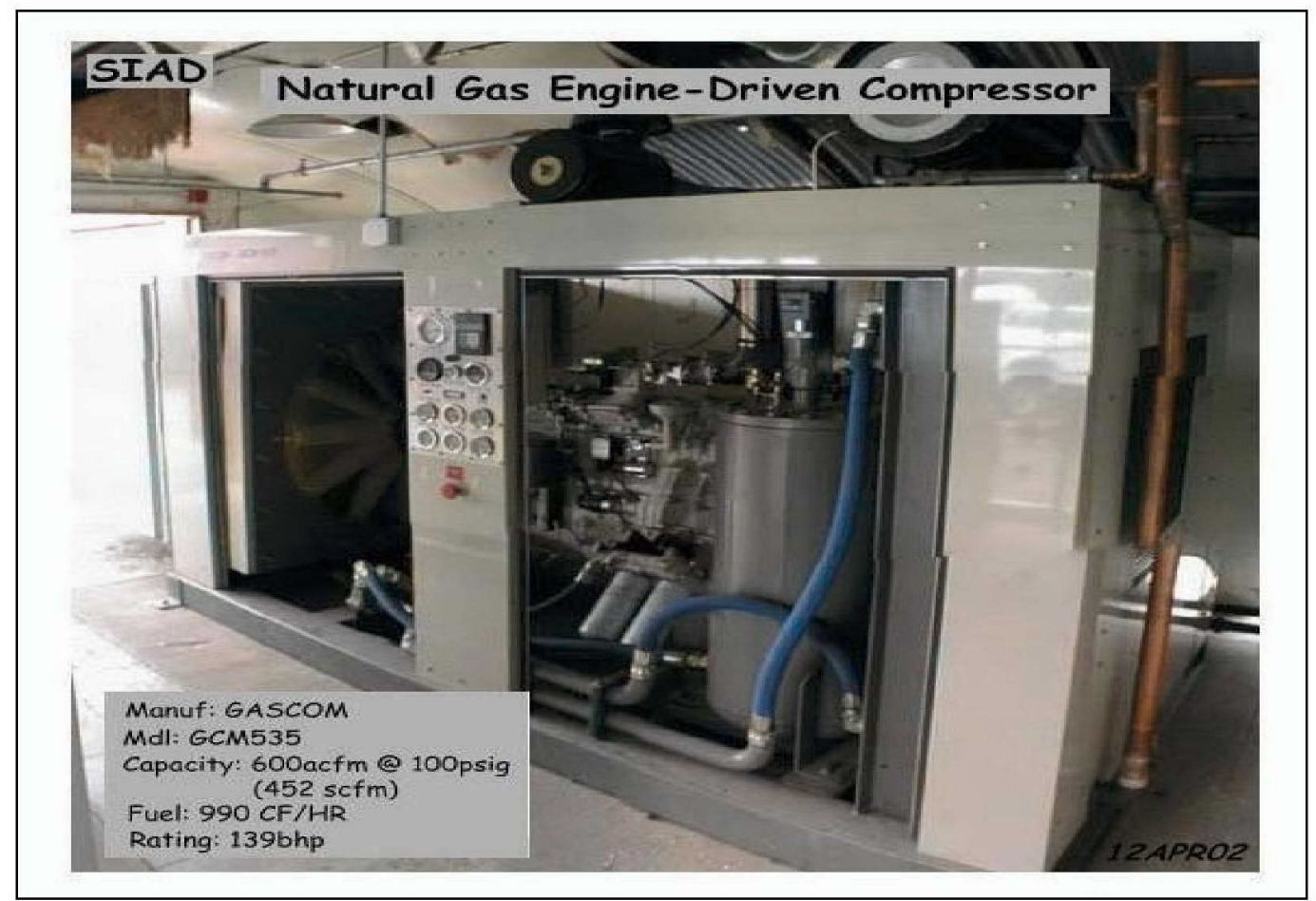

Figure 24. NGEDAC.

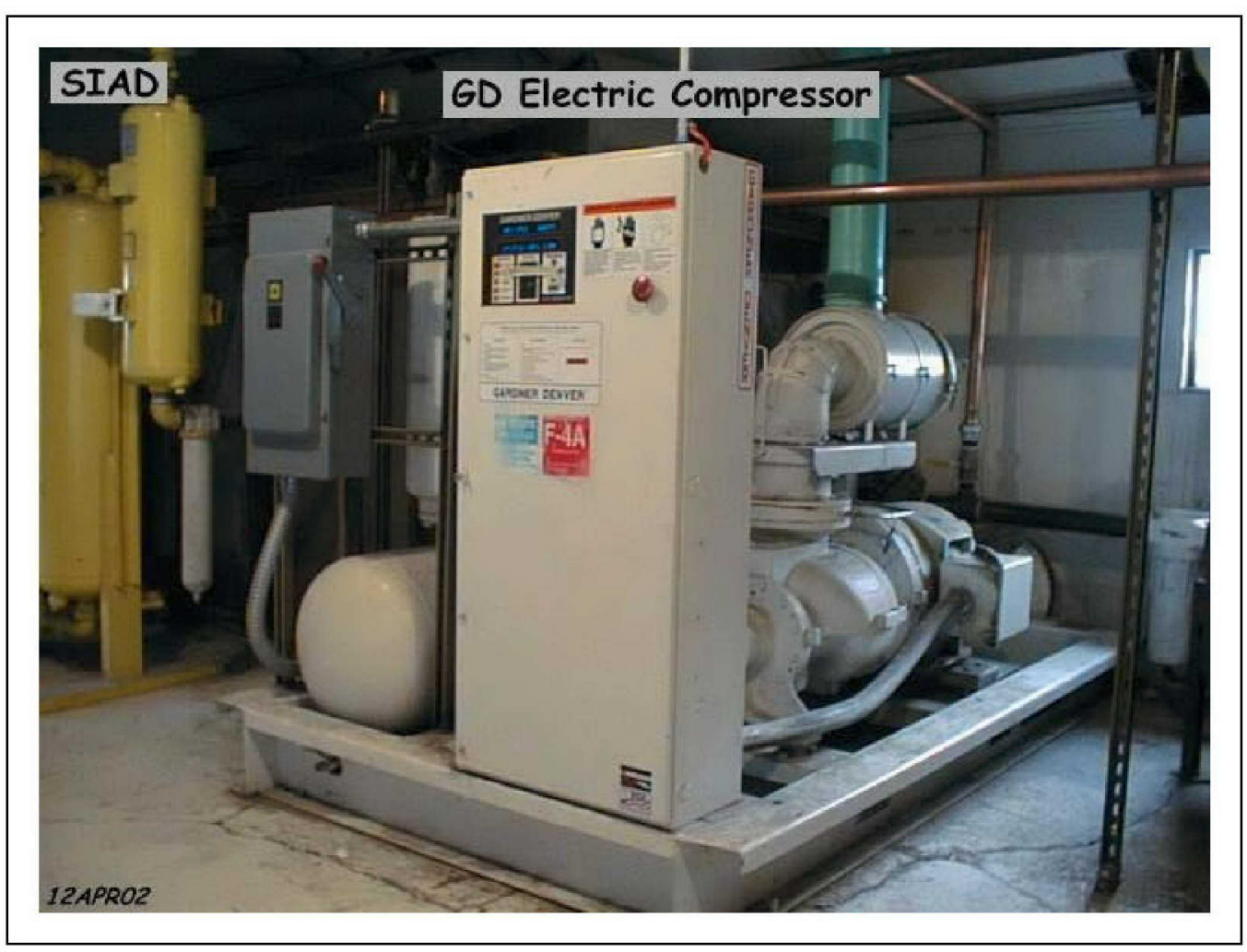

Figure 25. Backup electric compressor. 


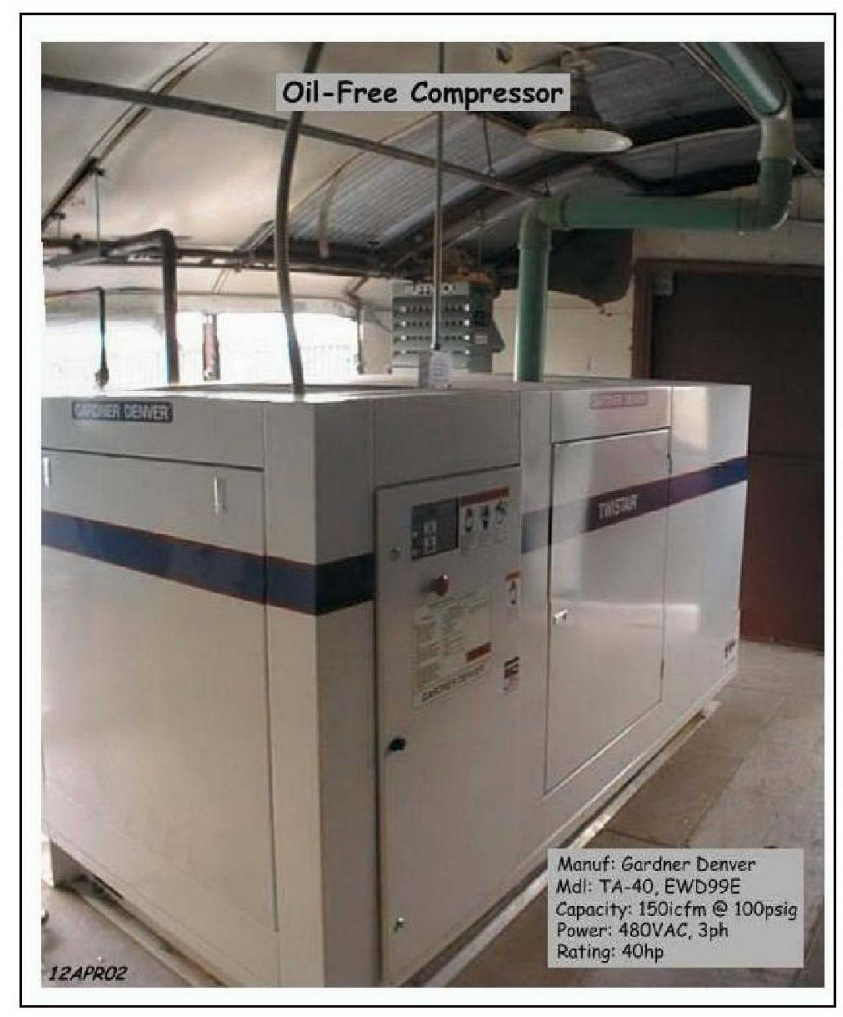

Figure 26. Oil-free compressor.

\section{Acceptance Testing/Commissioning}

Testing and commissioning of the air compressors and service systems is split into three (3) phases. Testing was performed by the various sub-contractors during installation and by SAIC per the inspection visits.

1. Equipment static check

2. Pre-commissioning power up

3. Functional test.

\section{Equipment Static Check}

The Equipment Static Check reviews the following items (when applicable):

1. Completion to installation drawings.

2. No evident mechanical damage to equipment.

3. No corroded parts, cleanliness of equipment/service and free from moisture.

4. Verify manufacturer's recommended method of installation and service sizing.

5. Verify fluids at proper levels, filters installed.

6. Verify fuse types and ratings.

7. Confirm grounding connections are correct.

8. Confirm wiring/cables are correctly identified and labeled. 


\section{Pre-Commissioning Power Up}

This step review the following items:

1. Verify main line voltages: phase-to-phase, phase-to-neutral, phase-to-ground.

2. Verify control panel low voltage (24VAC).

\section{Functional Test}

NGEDAC:

1. Static check

2. Purge air in natural gas line

3. Install catalyst bed in exhaust muffler/catalytic converter

4. Install air/fuel controls

5. Review control panel shutdown interface

6. Start engine and adjust fuel/air ratio

7. Verify engine running parameters (pressure, temp, rpm, voltage)

8. Inspect for leaks

9. Connect remote laptop and set final air/fuel parameters.

\section{Oil-Free Compressor}

1. Static check

2. Water sample taken and sent to 3rd party testing lab

3. Air and oil pressure regulator set

4. Controls set for machine rating

5. Controller programmed

6. Start motor

7. Verify motor running parameters (voltage, current, pressure, temp)

8. Inspect for leaks.

Compressor service systems include:

1. Mechanical and plumbing (M\&P)

2. Electrical.

Table 15 lists the various M\&P sub-systems and their service function. Table 16 summarizes the electrical service provided. Testing and commissioning of the compressors and service systems involved equipment static check, precommissioning power up and functional testing. 
Table 15. M\&P service to compressors.

\begin{tabular}{|c|c|c|c|}
\hline $\begin{array}{c}\text { Service to } \\
\text { NGEDAC }\end{array}$ & $\begin{array}{c}\text { Service } \\
\text { from } \\
\text { NGEDAC }\end{array}$ & $\begin{array}{c}\text { Service to } \\
\text { Oil-Free } \\
\text { Compressor }\end{array}$ & $\begin{array}{c}\text { Service from } \\
\text { Oil-Free Com- } \\
\text { pressor }\end{array}$ \\
\hline YES & - & YES & - \\
\hline YES & - & - & - \\
\hline- & - & YES & - \\
\hline- & YES & - & YES \\
\hline- & YES & - & - \\
\hline- & YES & - & YES \\
\hline YES & YES & - & - \\
\hline YES & YES & YES & YES \\
\hline
\end{tabular}

Table 16. Electrical service to compressor and equipment.

\begin{tabular}{|l|l|}
\hline Voltage & Equipment \\
\hline 480VAC, 3ph & 1. Oil-Free Compressor, 40hp \\
\hline & 1. Heat Recovery Pump \\
\hline & 2. NGEDAC lighting \\
\hline $208 Y / 120 \mathrm{VAC}, 3 \mathrm{ph}$ & 3. Oil-free Dryer \\
\hline & 4. Control Panel \\
\hline & 5. Monitoring Panel \\
\hline & 6. Sump Pump \\
\hline & 7. Service Outlet \\
\hline
\end{tabular}

\section{Operation and Maintenance Requirements}

\section{System Operation}

The operation of the air compressors can be performed via the compressor local control panel or the remote control panel. The remote control panel controls and/or monitors the following primary and secondary equipment (Table 17).

The control panel can only stop the Gascom NGEDAC compressor. Starting the NGEDAC must be done at the local control panel (stopping can be also done at the local panel). The control panel does not control the operation of Gardner Denver oil-free compressor. Starting and stopping of the oil-free compressor must be done at the local control panel. Table 18 summaries the remote control panel operation. 
Table 17. Equipment controlled by remote control panel.

\begin{tabular}{|l|l|}
\hline Primary Equipment & \multicolumn{1}{|c|}{ Secondary Equipment } \\
\hline 1) Gascom NGEDAC & 1) Heat Recovery Pump \\
\hline 2) GD Elect. Compressor (backup) & 2) Intake Air Dampers \\
\hline 3) GD Oil-Free Compressor (monitor only) & 3) Compressor Dampers \\
\hline 1) Make-up AHU (monitor only) & \\
\hline
\end{tabular}

Table 18. Remote control panel operation.

\begin{tabular}{|c|c|c|c|}
\hline Controlled Equipment & Auto Operation & Manual Start & Manual Stop \\
\hline 1. Gascom NGEDAC & 'AUTO' = Auto Shutdown & 'HAND' = Local Start & 'OFF' = Stop \\
\hline 2. GD Elect. Compressor (backup) & 'AUTO' = Auto Start/Stop & 'HAND' = Run & 'OFF' = Stop \\
\hline 3. GD Oil-free Compressor & NA & NA & NA \\
\hline 4. Heat Recovery Pump & 'AUTO' = Auto Start/Stop & 'HAND' = Run & 'OFF' = Stop \\
\hline $\begin{array}{l}\text { 5. Intake Air Dampers } \\
\text { (Room Louvers) }\end{array}$ & 'AUTO' = Auto Open/Close & 'OPEN' = Open & $\begin{array}{l}\text { 'CLOSE' = } \\
\text { Closed }\end{array}$ \\
\hline $\begin{array}{l}\text { 6. Compressor Dampers } \\
\text { (Exhaust \& Return) }\end{array}$ & $\begin{array}{l}\text { 'AUTO' = Auto Modulating } \\
\text { (room temp control) }\end{array}$ & $\begin{array}{l}\text { 'OPEN' = Open (Ex- } \\
\text { haust) }\end{array}$ & NA \\
\hline
\end{tabular}

\section{Local Operation - NGEDAC}

To Locally Start the NGEDAC (Figure 27):

1. Switch the Load Lever to the "UNLOAD" position.

2. Insert the ignition key and turn to the "On" position (clockwise).

3. Wait for the display to scroll through. If a fault is displayed push the fault reset button.

4. Push the "Main Relay Power" button in and hold.

5. Crank the engine for approximately 5 seconds until it starts.

6. If the engine does not start, turn the key to the "Off" position and wait for the pressure to relieve (approx. $20 \mathrm{sec}$.) and attempt to restart the engine.

7. Once the engine is running wait for 15 seconds for the switch gauges to clear the low set pins and release the Main Power Relay Button.

8. The engine will warm up for two (2) minutes before it will start the auto speed control system. Allow the engine to warm up until the water temperature reached at least $130^{\circ} \mathrm{F}$.

9. Place the unit on line by switching the Ioad Level to the "LOAD" position.

To Stop the NGEDAC:

1. Switch the Load Lever to the "UNLOAD" position.

2. Allow the engine to run until the engine water temperature is below $180^{\circ} \mathrm{F}$.

3. Turn the ignition key to the "Off" position (counterclockwise). 


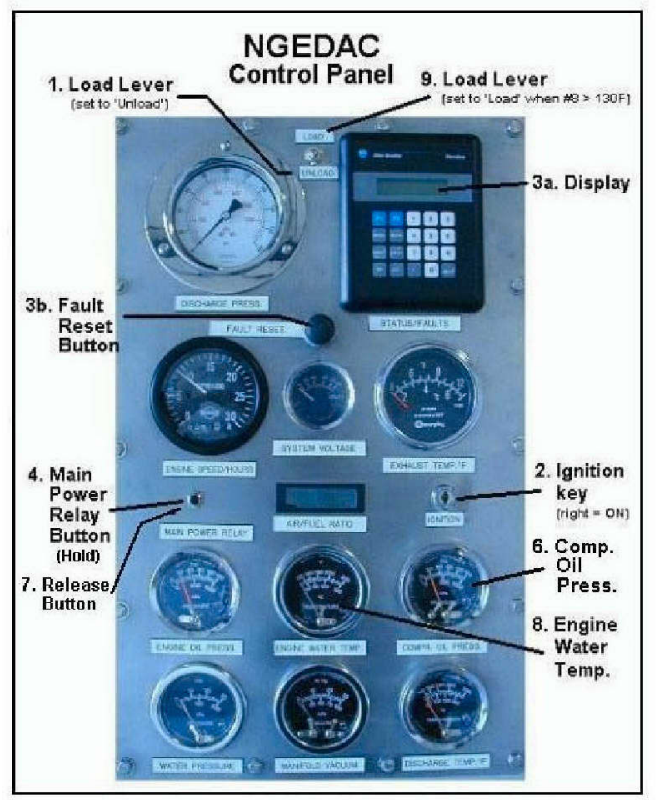

Figure 27. NGEDAC system controls.

\section{System Maintenance}

\section{Gascom NGEDAC - Maintenance Schedule}

The NGEDAC was purchased with a 2-year routine maintenance contract based on 2100 hours per year of operation (Appendix C). This includes 3 to 4 visits per year from the manufacturer's representative. Table 19 lists the items covered during this period, as well as maintenance actions required after the 4200 hours are reached.

\section{GD Oil-Free Compressor - Maintenance Schedule}

Table 20 lists the maintenance schedule for the Gardner Denver oil-free compressor.

\section{HVAC System}

The quality of the propylene glycol/water mix in the heat recovery loop must be checked annually, prior to winter, to ensure that adequate freeze protection is provided, and that the mixture is free of corrosive agents. A multi-purpose test strip can be used to test for the condition of the mixture. 
Table 19. Gascom NGEDAC maintenance schedule.

\begin{tabular}{|c|c|c|c|c|c|c|c|c|c|}
\hline Activity/Intervals & $\begin{array}{c}\text { Daily } \\
\text { Inter- } \\
\text { val } \\
\end{array}$ & $\begin{array}{c}\text { 1st 10-20 } \\
\text { Hrs. }\end{array}$ & $\begin{array}{l}400 \\
\text { hrs. }\end{array}$ & $\begin{array}{l}600 \\
\text { Hrs. }\end{array}$ & $\begin{array}{l}2000 \\
\text { Hrs. }\end{array}$ & $\begin{array}{l}6000 \\
\text { Hrs. }\end{array}$ & $\begin{array}{c}3 \\
\text { Mo. }\end{array}$ & $\begin{array}{c}6 \\
\text { Mo. }\end{array}$ & $\begin{array}{l}\text { An- } \\
\text { nual }\end{array}$ \\
\hline Check Coolant Level, engine \& comp. oil level & $\checkmark$ & & & & & & & & \\
\hline Chg. engine oil/filter & & $\checkmark$ & & $\checkmark$ & & & & & \\
\hline Check/adj drive belts & & $\checkmark$ & & $\checkmark$ & & & & & \\
\hline Retighten cal. head bolts & & $\checkmark$ & & & & & & & \\
\hline Check/adj. valves & & $\checkmark$ & $\checkmark$ & $\checkmark$ & & & & & \\
\hline check/tighten hoses, lamps \& mounts & & & & & & & $\checkmark$ & & \\
\hline Service air filters & & & & $\checkmark$ & & & & & \\
\hline Chg. oxygen sensors & & & & & $\checkmark$ & & & & \\
\hline Chg. spark plugs & & & & & $\checkmark$ & & & & \\
\hline Check compression & & & & & $\checkmark$ & & & & \\
\hline Check ignition timing & & & & & $\checkmark$ & & & & \\
\hline Chg. distributor rotor \& cap & & & & & & $\checkmark$ & & & \\
\hline Check throttle shaft bushings for leaks & & & & & & $\checkmark$ & & & \\
\hline Check anti-freeze concentration & & & & & & & & $\checkmark$ & \\
\hline Clean inlet gas strainer & & & & & & & & & $\checkmark$ \\
\hline Leak test inlet gas regulator system & & & & & & & & $\checkmark$ & \\
\hline Change anti-freeze & & & & & & & & & $\checkmark$ \\
\hline Grease fan shaft bearings & & & & $\checkmark$ & & & & & \\
\hline Inspect exhaust system, drain muffler & & & & & & & $\checkmark$ & & \\
\hline Chg. comp. oil/filter & & & & & $\checkmark$ & & & & \\
\hline Clean radiator fins & & & & & & & $\checkmark$ & & \\
\hline Chg. anode on shell \& tube coolers & & & & & & & & & $\checkmark$ \\
\hline
\end{tabular}


Table 20. GD oil-free compressor maintenance schedule.

\begin{tabular}{|c|c|c|c|c|c|c|}
\hline Activity & $\begin{array}{l}\text { As Indicated } \\
\text { by Autosentry }\end{array}$ & $8 \mathrm{hr}$. & $125 \mathrm{hr}$. & $500 \mathrm{hr}$. & 2000 hr. $^{*}$ & $\begin{array}{l}\text { Annual } \\
\text { Interval }\end{array}$ \\
\hline Change Air Filter & $\checkmark$ & & & & & \\
\hline Change Water Filter & $\checkmark$ & & & & & \\
\hline Check for Proper Load/Unload & & $\checkmark$ & & & & \\
\hline Check Discharge Pressure/Temp & & $\checkmark$ & & & & \\
\hline Check Dirt Accumulation on Cooler & & & $\checkmark$ & & & \\
\hline Check Reservoir Oil Level & & & $\checkmark$ & & & \\
\hline Check Condensate in Air Filter Bowl & & & $\checkmark$ & & & \\
\hline Change Compressor Lubricant (AEON 800) & $\checkmark$ & & & & $\checkmark$ & $\checkmark$ \\
\hline Check Relief Valve & & & & & & $\checkmark$ \\
\hline Check Minimum Pressure Valve Seals & & & & & & $\checkmark$ \\
\hline Change Oil Filter Element & $\checkmark$ & & & & $\checkmark$ & \\
\hline Check Water Quality** & & & $\checkmark$ & & & \\
\hline Check Water Flow (RO Filter Discharge) & & & & $\checkmark$ & & \\
\hline Inspect Makeup Water Treatment Cartridges & & & & & $\checkmark$ & \\
\hline \multicolumn{7}{|c|}{$\begin{array}{l}\text { "If OIL IS ANALYZED at the end of a maintenance interval ( } 2000 \mathrm{hr} \text {. max.) and is found in good condition, it may be used for the next } 2000 \text { hour } \\
\text { interval - GD provides oil analysis services. OTHERWISE, IF OIL IS NOT ANALYZED at the end of any interval, it must be changed. }\end{array}$} \\
\hline
\end{tabular}




\begin{tabular}{l}
\hline Notes (to Table 20): \\
8 Hour Interval \\
1. Observe if the unit loads and unloads properly. \\
2. Check discharge pressure \& temperature. \\
3. Check Panel Status indicators \& messages line for advisories. \\
\hline 125 Hour Interval \\
1. Check for dirt accumulation on oil/aftercooler core faces and the cooling fan. If cleaning is required, clean the exterior fin \\
surfaces of the cores by blowing compressed air carrying a nonflammable safety solvent in a direction opposite that of the \\
cooling fan air flow. this cleaning operation will keep the exterior cooling surfaces clean and ensure effective heat dissipa- \\
tion. \\
2. Check the air-end reservoir oil level - add oil if required. Loss of oil will be because of seal failure or leaks in the system \\
and should be fixed immediately. \\
3. Check the level of condensate in the control air filter bowl. Use the manual pet cock to evacuate any accumulation and \\
check the operation of the automatic float valve. cleanse the automatic float valve as needed. \\
4. Check the quality of the raw (incoming), RO (treated) and injection (reservoir) water. Refer to Section 8 of the Gardner \\
Denver O\&M manual for recommendations to check the water quality. \\
\hline 500 Hour Interval \\
1. Check the delivery of filtered water from the reverse osmosis (RO) system. \\
Refer to the RO Filtration System, Section 8 of the GD O\&M manual, for the recommended procedure. \\
\hline 2000 Hour Interval \\
1. Change the air-end lubricant. UNDER ADVERSE CONDITIONS, CHANGE MORE FREQUENTLY (refer to "Oil Change \\
Interval" in Section 5 of the GD O\&M manual). Flush reservoir if required. DON NOT MIX LUBRICANTS. \\
2. Visually inspect makeup water cartridge. Replace when no material is observed in the cartridge. \\
\hline Annual Interval \\
Check the relief valve for proper operation. See Section 4, pg. 33 of the GD O\&M manual. \\
\hline
\end{tabular}


Table 21. NGEDAC and oil-free compressor systems training at SIAD.

\begin{tabular}{|l|l|l|l|}
\hline Equipment & \multicolumn{1}{|c|}{ Company } & Trainer & Date \\
\hline GD Oil-Free Compressor & Accurate Air & Daniel Gillaspy & $21 \mathrm{Mar02}$ \\
\hline Gascom Compressor & Gascom & Mike Bloemen & $11 \mathrm{Apr02}$ \\
\hline
\end{tabular}

\section{Training}

The manufacturer or distributor performed operational training to run the compressor equipment. SIAD maintenance staff attended the training session (Table 21) for the NGEDAC, which took place on 11 April 2002.

Training included review of the O\&M manuals, operating, maintenance and safety procedures and a site visit to the compressor room. All attendees were given a live demonstration on starting and stopping the compressors.

\section{Comparative Analysis}

\section{Existing System - Performance and Economics}

Performance information about the existing compressed air system was collected between 6 September and 1 October 2001. SAIC subcontracted Accurate Air Engineering, Inc. to conduct the monitoring of the existing compressed air system for the September data collection period. Accurate Air conducted the following tasks:

1. Provide all system monitoring hardware

2. Install monitoring system

3. Provide SAIC access to the monitoring system during the monitoring period

4. Conducting monitoring for a period of 14 days

5. Remove the monitoring system upon completion of data collection

6. Provide all data to SAIC.

The list of monitoring points is:

- electric air compressor energy consumption (kW)

- compressor discharge air pressure (psig)

- compressor discharge air temperature (of)

- compressor total air flow rate (scfm)

- process air flow rate (scfm)

- compressor inlet air temperature (of) and relative humidity (\%RH). 
The compressor electric consumption was measured using a Veris Industries, Inc. power meter installed at the compressor disconnect. Air flow was monitored using Eldridge Products, Inc. insertion mass flow meters installed in the air compressor discharge piping prior to the dryer and the process air line after the split to the breathing air line. The flow meters were installed into the compressed air lines through pipe saddles with isolation valves that allowed the $3 / 4$-in diameter holes to be drilled and inserted into the pipes. The breathing air flow rate was calculated as the difference between the total air flow and the process air flow. The compressed air pressure was measured with a pressure transducer installed at a threaded coupling on the receiver. The compressed air temperature was measured near the process air flow measurement using a surfacemounted RTD that was covered with insulation. The compressor air inlet conditions were measured as outdoor ambient air conditions. All the sensors were interfaced to a Westronics Ranger data recorder. The recorder provided a means of scaling the analog signals, reading the sensors, and recording the data values. Data was collected as statistical representations of data in 5 minute intervals.

The monitoring system was installed on Thursday, 6 September 2001. Since the Base is closed on Friday, Saturday, and Sunday, the first day of data collection that included compressor operation was Monday, 10 September. Table 22 and Figure 28 give the 10 September data.

Due to the events of 11 September 2001 the "typical" operation of the Base and Bldg 210 were altered. The compressor did not operate between 11 and 16 September. When operation resumed, the quantity of compressed air consumption was lower than anticipated as can be seen in the data collected for 20 September (Table 23):

Table 24 summarizes the data collected between 6 September and 1 October. The average total air flow was 153.7 SCFM during this period, with a peak of 481.9 SCFM. The process air stream average air flow was 73.9 SCFM, with a peak of 460.8 SCFM. As presented in the Sept. 20th graph (Figure 29) the peak air flow rates typically occur when the compressor is first turned on at the beginning of the workday and the system is being pressurized.

On 1 October, SAIC requested that the Base conduct operations such that the potential maximum compressed air demand would be observed in the data. Figure 30 shows the data for this scenario. The peak total air flow is 460 SCFM, the peak process air flow is approximately 300 SCFM and the peak breathing air flow is approximately 200 SCFM. 
Table 22. Compressor operation, 10 September 2001.

\begin{tabular}{|l|c|l|c|}
\hline & & & $\begin{array}{l}\text { Percent of } \\
\text { Design Capacity }\end{array}$ \\
\hline Hours of Operation & 10.42 & Hours & \\
\hline Total Air Flow & & & \\
\hline Average & 166.7 & SCFM & $37 \%$ \\
\hline Maximum & 343.9 & SCFM & $76 \%$ \\
\hline Process Air Flow & & & \\
\hline Average & 90.2 & SCFM & $20 \%$ \\
\hline Maximum & 347.2 & SCFM & $77 \%$ \\
\hline Breathing Air Flow & & & \\
\hline Average & 76.5 & SCFM & $17 \%$ \\
\hline Maximum & 140.3 & SCFM & $31 \%$ \\
\hline Power Consumption & & & \\
\hline Average & 95.6 & $\mathrm{~kW}$ & $86 \%$ \\
\hline Maximum & 103.6 & $\mathrm{~kW}$ & $94 \%$ \\
\hline Average Efficiency & 1.74 & SCFM/kW & \\
\hline
\end{tabular}

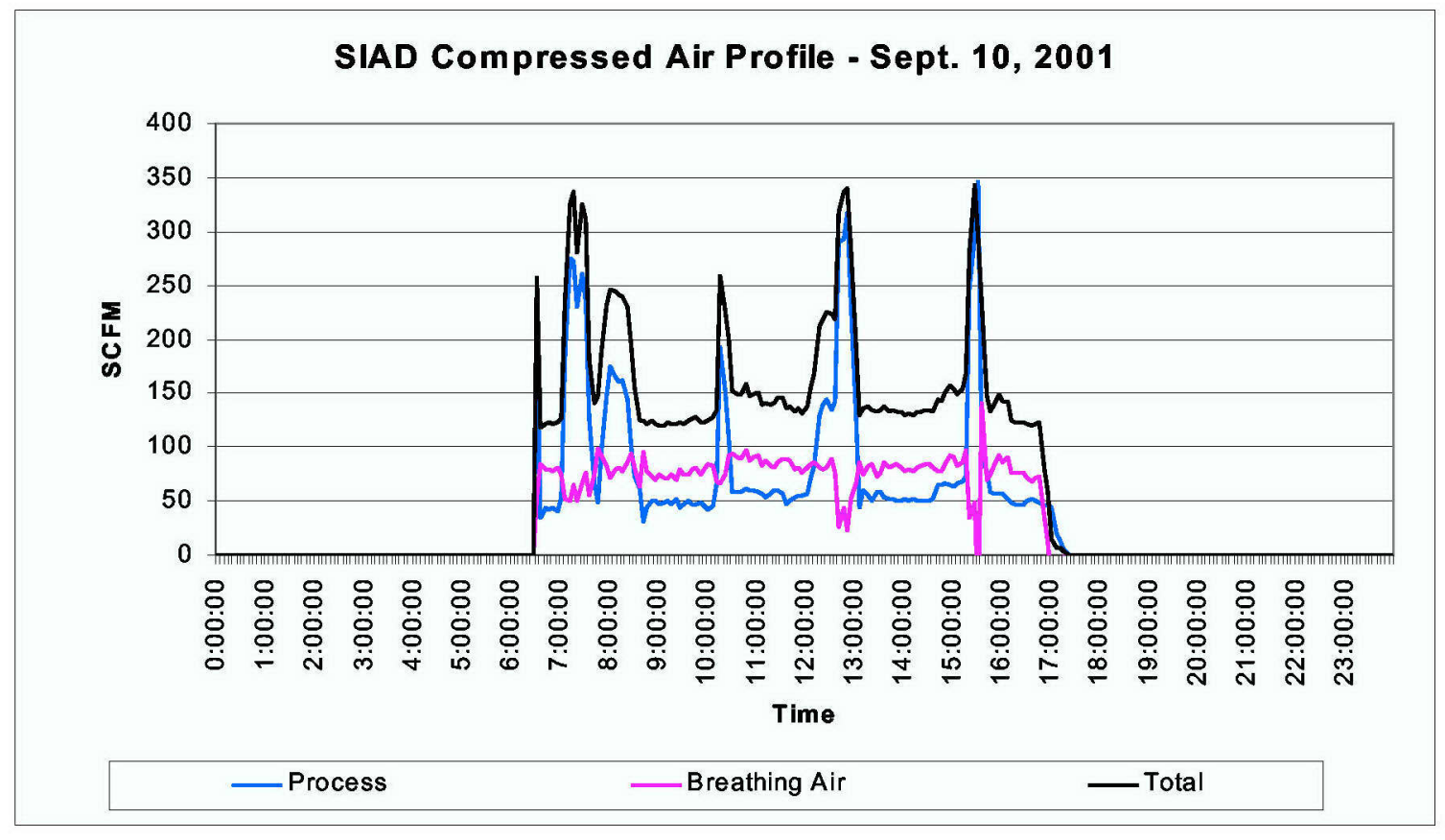

Figure 28. SIAD compressed air profile—10 September 2001. 
Table 23. Compressor operation, 20 September 2001.

\begin{tabular}{|l|l|l|l|}
\hline & & & $\begin{array}{l}\text { Percent of Design Capac- } \\
\text { ity }\end{array}$ \\
\hline Hours of Operation & 10.17 & Hours & \\
\hline Total Air Flow & & & \\
\hline Average & 140.0 & SCFM & $31 \%$ \\
\hline Maximum & 380.1 & SCFM & $84 \%$ \\
\hline Process Air Flow & & & $16 \%$ \\
\hline Average & 69.8 & SCFM & $119 \%$ \\
\hline Maximum & 534.2 & SCFM & \\
\hline Breathing Air Flow & & & $16 \%$ \\
\hline Average & 70.2 & SCFM & $22 \%$ \\
\hline Maximum & 97.0 & SCFM & \\
\hline Power Consumption & & & $84 \%$ \\
\hline Average & 93.1 & kW & $86 \%$ \\
\hline Maximum & 95.4 & kW & \\
\hline Average Efficiency & 1.50 & SCFM/kW & \\
\hline
\end{tabular}

Table 24. Compressor operation summary.

\begin{tabular}{|l|c|c|c|}
\hline & Sept. 6 - Oct. 1, 2002 & Percent of Design Capacity & \\
\hline Hours of Operation & 112.42 & Hours & \\
\hline Total Air Flow & & & \\
\hline Average & 153.7 & SCFM & $34 \%$ \\
\hline Maximum & 481.9 & SCFM & $107 \%$ \\
\hline Process Air Flow & & SCFM & \\
\hline Average & 73.9 & SCFM & $16 \%$ \\
\hline Maximum & 460.8 & & $102 \%$ \\
\hline Breathing Air Flow & & SCFM & \\
\hline Average & 80.1 & SCFM & $18 \%$ \\
\hline Maximum & 212.3 & & $47 \%$ \\
\hline Power Consumption & & $\mathrm{kW}$ & \\
\hline Average & 94.5 & $\mathrm{~kW}$ & $85 \%$ \\
\hline Maximum & 108.4 & SCFM/kW & $98 \%$ \\
\hline Average Efficiency & 1.63 & & \\
\hline
\end{tabular}




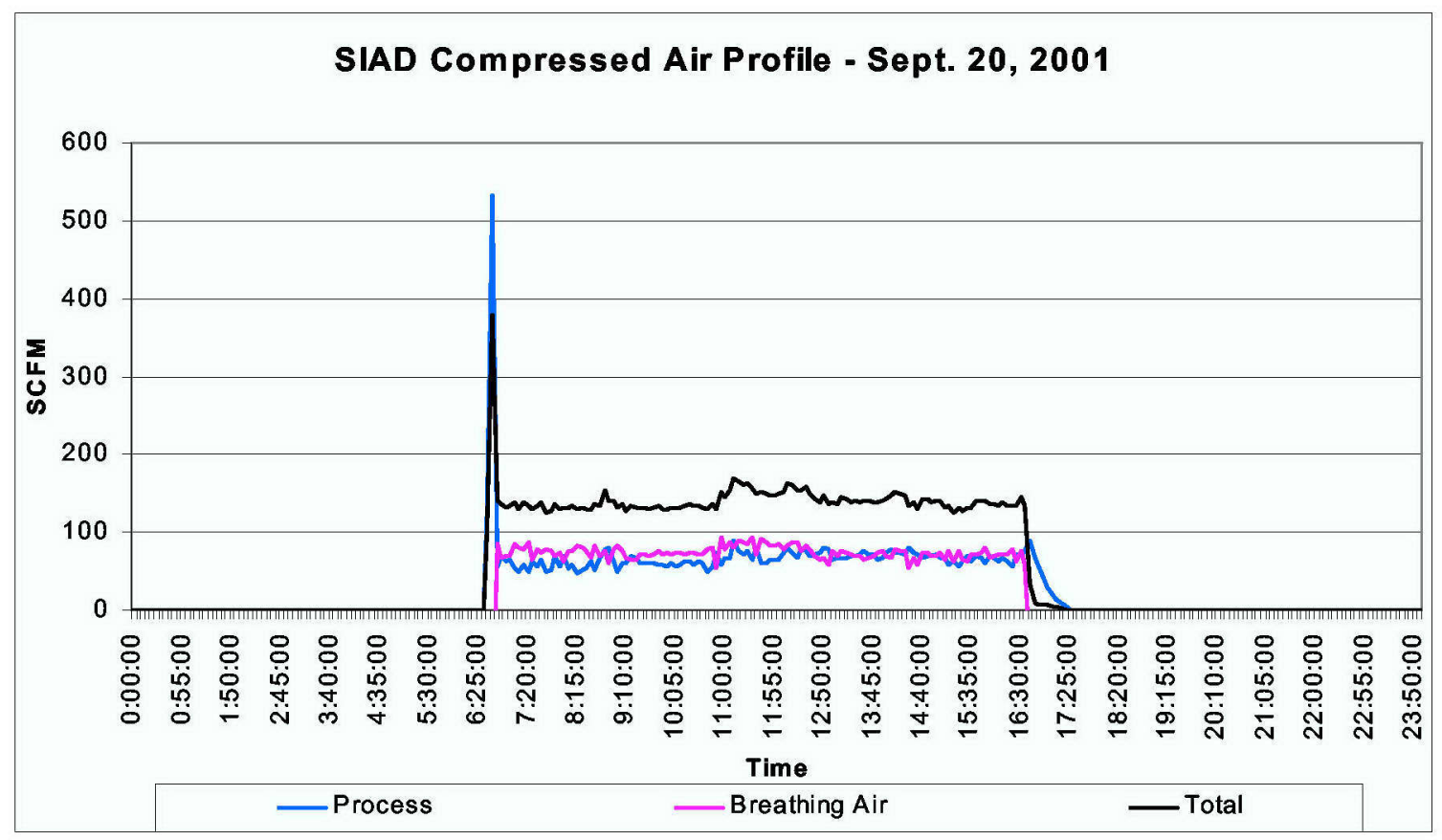

Figure 29. SIAD Compressed Air Profile, 20 September 2001.

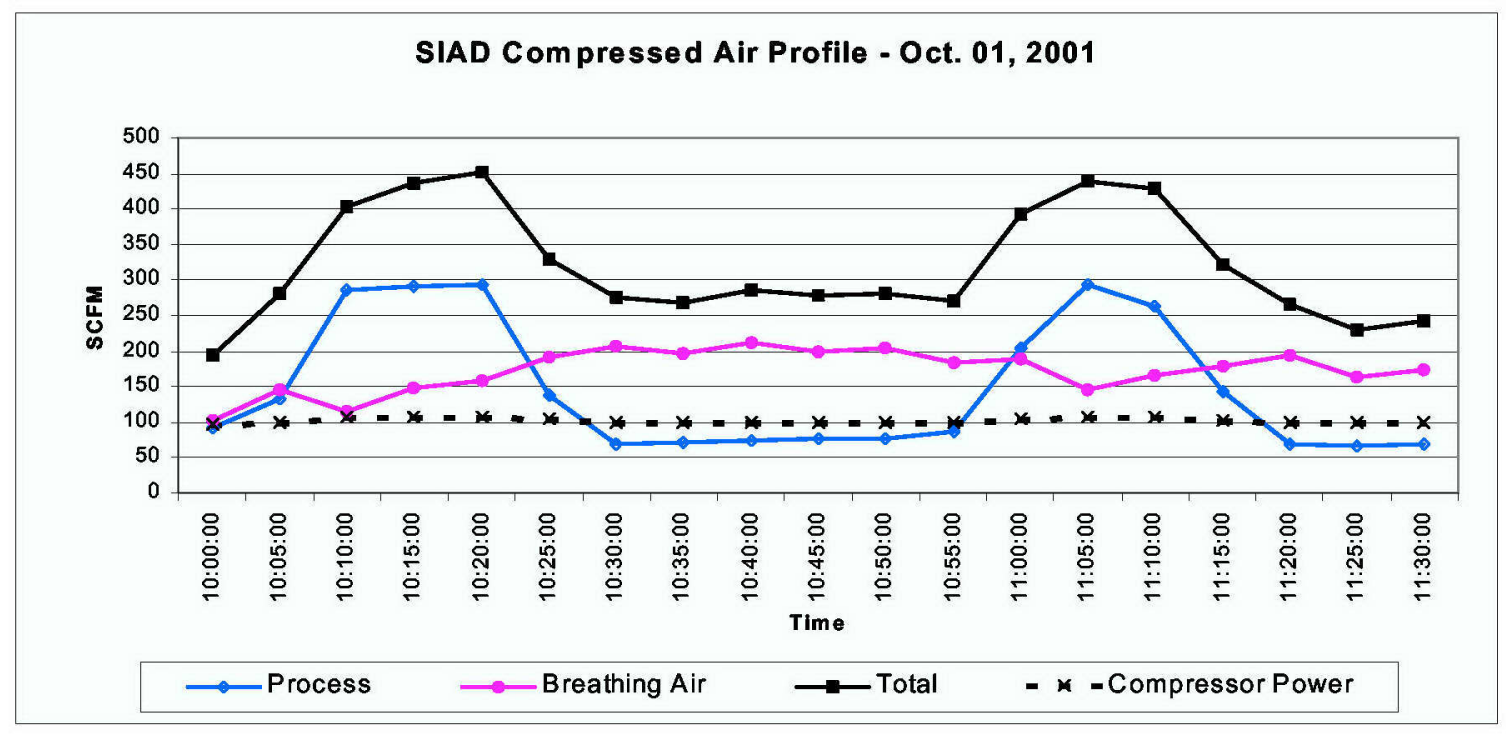

Figure 30. SIAD compressed air profile—01 October 2001.

The electrical power consumed by the compressor stayed in a relatively narrow band, regardless of airflow. Figure 31 shows a typical day. The control for the unit is set at a constant run mode to ensure that a low voltage condition does not occur. This means higher power consumption than if the unit could be operated in the low demand or automatic modes. 


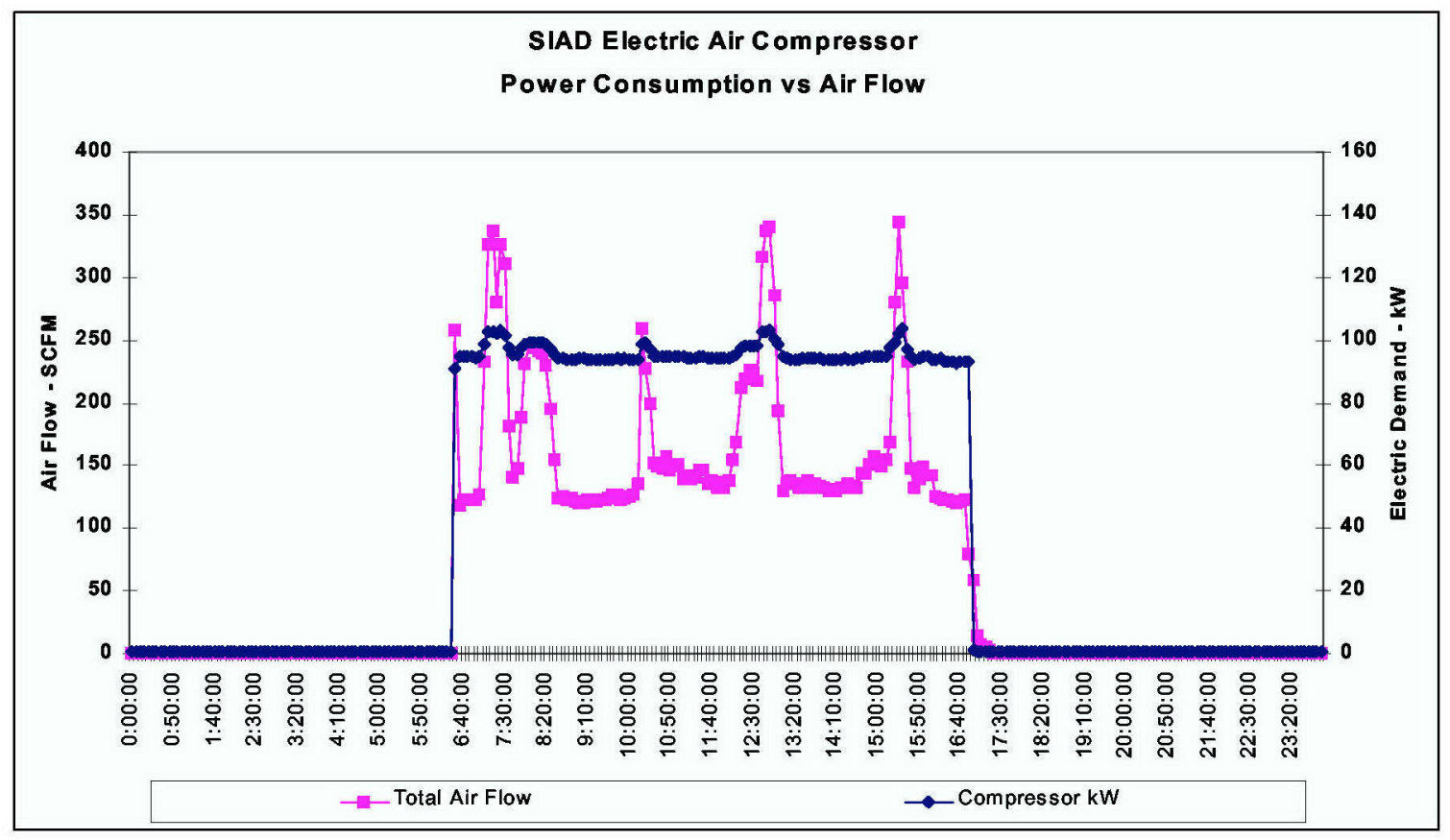

Figure 31. SIAD electric air compressor power consumption vs. air flow.

Table 25. SIAD electric air compressor performance.

\begin{tabular}{|c|c|c|c|c|}
\hline \multirow{2}{*}{\begin{tabular}{|l|} 
Design Load \\
$450 \mathrm{scfm} \quad(600 \mathrm{icfm})$ \\
\end{tabular}} & \multicolumn{4}{|c|}{ Efficiency (scfm/kW) } \\
\hline & $100 \%$ Load & $75 \%$ Load & $50 \%$ Load & $25 \%$ Load \\
\hline Manufacturer Specifications $^{1}$ & 4.15 & 3.81 & 3.1 & 1.73 \\
\hline Measured $^{2}$ & 4.17 & 3.55 & 2.37 & 1.18 \\
\hline \multicolumn{5}{|c|}{$\begin{array}{l}1 \text { Gardner Denver Engineering Data Sheet: Electra-Saver Turn Valve Compressors, } 60 \mathrm{~Hz} \\
\text { Specifications, Nominal Main Compressor Motor Amperage Draw at Various Load Condi- } \\
\text { tions for } 100 \text { psig Discharge, } 13-10-400 \text {, 4th Edition, November } 1995 \text {. For Model EAQ } \\
125 \text { at } 460 \mathrm{~V} \text {, assuming } 110.6 \mathrm{~kW} \text { design power, and percent power as a linear function of } \\
\text { motor amperage draw. }\end{array}$} \\
\hline \multicolumn{5}{|c|}{$\begin{array}{l}2 \text { Based on average of data taken during September } 2001 \text { and October 1, } 2001 \text { using } \\
\text { measured total air flow supplied by compressor and power recorded by wattmeter. }\end{array}$} \\
\hline
\end{tabular}

The data in Table 25 show the relatively inefficient operation of the compressor in the constant run mode, which becomes evident the measured performance of the unit is compared with the manufacturer's specifications.

\section{NGEDAC System-Performance and Economics}

Performance data for the NGEDAC was collected over a 2-week period (01-15 May 2002). This was accomplished by use of a new monitoring system that will remain at SIAD beyond the completion of the contract. A description of the monitoring system and the results of the data analysis is provided below. 


\section{NGEDAC Monitoring Equipment}

The monitoring system has been designed to obtain the following information about the operation of the NGEDAC:

- Natural Gas Flow (acfm)

- Heat Recovery Flow (gpm)

- Heat Recovery Inlet Temperature $\left({ }^{\circ} \mathrm{F}\right)$

- Heat Recovery Outlet Temperature $\left({ }^{\circ} \mathrm{F}\right)$

- Compressor Discharge Air Pressure (psig)

- Compressor Discharge Air Temperature $\left({ }^{\circ} \mathrm{F}\right)$

- Compressor Discharge Air Flow Rate (scfm)

- Outdoor Ambient Air Temperature ( $\left.{ }^{\circ} \mathrm{F}\right)$ and Relative Humidity (\%RH).

The natural gas flow is measured using a Roots rotary meter model 15C175-TC that is temperature compensated and includes a pulse contactor. In addition to the pulser, the meter has an analog totalizer display. The meter is rated for $0-$ $1500 \mathrm{acfm}$ at a maximum pressure of $175 \mathrm{psig}$. The meter is sized for a nominal 2-in. natural gas pipe. The pulser provides one pulse per $10 \mathrm{cu} f t$ of gas measured. The gas meter is installed adjacent to the NGEDAC.

The heat recovery flow is measured using an inline turbine meter manufactured by Niagara. The model MTX 421-1.5 is specifically designed for hot fluid applications in $1 \frac{1}{2}$-in. piping. The meter is capable of measuring flow rates from 3 to $85 \mathrm{gpm}$ and provides a field configurable pulse contact at resolutions of one pulse per $10 \mathrm{gal}$ or one pulse per $100 \mathrm{gal}$. The flow meter is installed adjacent to the NGEDAC.

The compressed air flow is measured using an insertion mass flow meter manufactured by Sierra Instruments. The meter, model 640-NAA-L09-EN2-P2-V4NR-0, is specified and factory calibrated for 600 SCFM at 100 psig for $100^{\circ} \mathrm{F}$ air when applied to a 2-in. pipe. The meter has the capability to be customized for additional applications using the manufacturer-provided software. The meter is installed to provide an output signal of 4-20 $\mathrm{mA}$ and has an accuracy of 2 percent. The air flow meter is installed at the pipe saddle that was installed for compressor monitoring of the electric motor driven air compressor, in the piping between the receiver and the dryer of the process air line.

The temperature measurements are conducted using 2-wire RTD's interfaced to signal conditioners that provide a 4-20 mA signal output. Table 26 summarizes the temperature sensors and the factory-calibrated operating temperature ranges. The temperature sensors are manufactured by Building Automation Products, Inc. 
Table 26. SIAD compressed air system temperature sensors installed.

\begin{tabular}{|l|l|l|l|}
\hline \multirow{2}{*}{ Temperature Sensors } & & \multicolumn{2}{c|}{ Sensor Range } \\
\cline { 3 - 5 } & Model Number & Min $\left({ }^{\circ} \mathbf{F}\right)$ & Max $\left({ }^{\circ} \mathbf{F}\right)$ \\
\hline Heat Recovery Inlet Temperature & BA/T100M-I-4-R & 0 & 250 \\
\hline Heat Recovery Outlet Temperature & BA/T100M-I-4-R & 0 & 250 \\
\hline Compressed Air Temperature & BA/T100M-S & 0 & 130 \\
\hline Outdoor Ambient Air Temperature & BA/T100M-H300 & 0 & 130 \\
\hline
\end{tabular}

The heat recovery temperature sensors are insertion probes that are installed in thermowells located in the heat recovery piping. Note that the outdoor ambient relative humidity is included as part of the outdoor ambient air temperature sensor and has an operating range of $0-100$ percent $\mathrm{RH}$.

The compressed air pressure measurement is conducted using a pressure transducer manufactured by Viatran, Inc. (Model 3475APG) which is factory calibrated for an operating range of $0-200$ psig and provides an output signal of 4$20 \mathrm{~mA}$. The pressure transducer is installed at the process air receiver.

The sensors are interfaced to data logging hardware manufactured by Campbell Scientific, Inc. The major components of the data logger monitoring system are:

- CR10X Measurement and Control Module

- PS12LA Power Supply with Battery Backup

- COM9600 Modem

- 24 VDC Power Supply

- Two Terminal Strips for sensor termination.

These components have been assembled into a system and mounted in an electrical enclosure inside the existing compressor room. Figure 32 show the layout of the monitoring system hardware within the enclosure.

\section{Monitoring System Enclosure Layout}

The monitoring system was prefabricated with only the sensor field wiring terminations required at the time of installation at SIAD. Table 27 lists the legend for the sensor wiring guide.

TS1 and TS2 correspond to terminal strips number one and two respectively. The color designations indicate the color of the wire within the sensor cable used for the termination. 


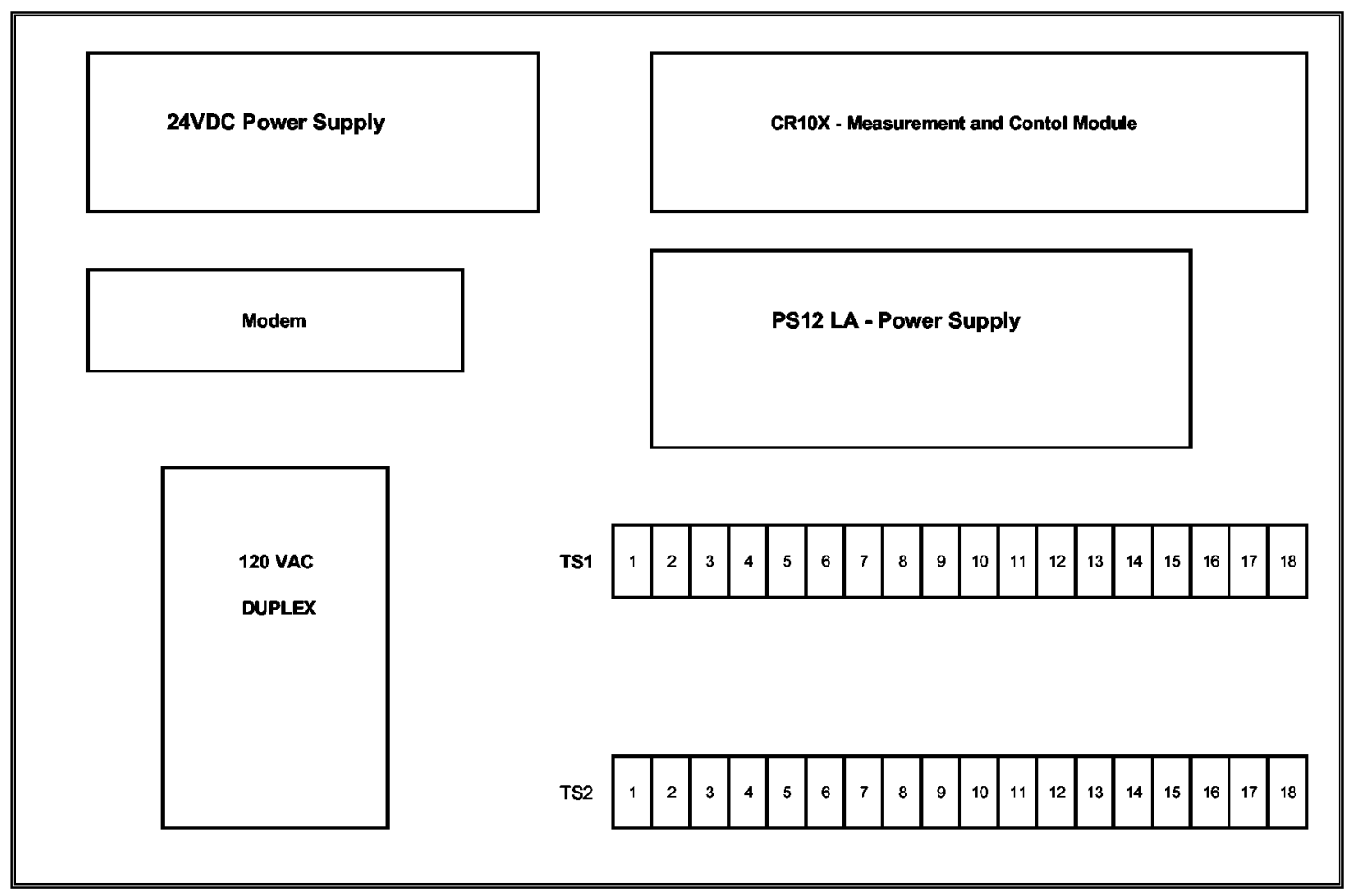

Figure 32. Monitoring system enclosure layout.

Table 27. SIAD monitoring system sensors wiring guide.

\begin{tabular}{|l|l|l|l|l|l|}
\hline Measurement & \multicolumn{1}{|c|}{ Symbol } & \multicolumn{1}{|c|}{ Plus } & \multicolumn{1}{|c|}{ Minus } & \multicolumn{1}{c|}{ Plus } & \multicolumn{1}{c|}{ Minus } \\
\hline Natural Gas Flow & F Gas & P1 & G & P1 (red) & G (black) \\
\hline Heat Recovery Flow & F HR & P2 & G & P2 (red) & G (black) \\
\hline Heat Recovery Inlet Temperature & T inlet & 1H (blue) & AG & TS1-1 (red) & TS1-7 (black) \\
\hline Heat Recovery Outlet Temperature & T outlet & 1L (red) & AG & TS1-2 (red) & TS1-9 (black) \\
\hline Compressed Air Temperature & T CA & 2H (white) & AG & TS1-3 (red) & TS1-11 (black) \\
\hline Outdoor Ambient Air Temperature & T amb & 2L (blue) & AG & TS1-4 (red) & TS1-13 (black) \\
\hline Outdoor Ambient Air Relative Humidity & RH amb & 3H (red) & AG & TS1-5 (white) & TS1-15 (green) \\
\hline Compressed Air Pressure & P CA & 3L (white) & AG & TS1-2 (red) & TS1-17 (black) \\
\hline Compressed Air Flow & F CA & 4H (white) & 4L (purple) & TS1-3 (red) & TS1-6 (black) \\
\hline
\end{tabular}

The data logger is programmed to scan all the sensors once every 2 seconds. The CR10X reads either a contact closure from the gas and water meters or a millivolt signal from the analog sensors. Each milliamp signal has been wired through a $24 \mathrm{VDC}$ and resistor loop to convert the milliamps into millivolts. All resistors have an accuracy of 1 percent. The CR10X has been programmed to convert the $\mathrm{mV}$ signal into engineering units. Table 28 summarizes the sensor resistor and linear conversion factors in terms of a multiplier and offset for each sensor. 
Table 28. Sensor range, output, resistance, and scaling factors

\begin{tabular}{|c|c|c|c|c|c|c|c|c|c|}
\hline \multirow[b]{2}{*}{ No. } & \multirow[b]{2}{*}{ Measurement } & \multirow[b]{2}{*}{ Symbol } & \multicolumn{2}{|c|}{ Sensor Range } & \multicolumn{2}{|c|}{ Sensor output (mA) } & \multirow{2}{*}{\begin{tabular}{c|} 
Resistor \\
ohms \\
\end{tabular}} & \multicolumn{2}{|c|}{ Sensor Scaling } \\
\hline & & & Min & Max & Min & Max & & multiplier & Offse \\
\hline 1 & Natural Gas Flow & F Gas & 0 & 10 & & & $\mathrm{n} / \mathrm{a}$ & 0 & 10 \\
\hline 2 & Heat Recovery Flow & $\mathrm{FHR}$ & 0 & 10 & & & $\mathrm{n} / \mathrm{a}$ & 0 & 10 \\
\hline 3 & Heat Recovery Inlet Temperature & T inlet & 0 & 250 & 4 & 20 & 100 & 0.1563 & -62.5 \\
\hline 4 & Heat Recovery Outlet Temperature & T outlet & 0 & 250 & 4 & 20 & 100 & 0.1563 & -62.5 \\
\hline 5 & Compressed Air Temperature & TCA & 0 & 130 & 4 & 20 & 100 & 0.0813 & -32.5 \\
\hline 6 & Outdoor Ambient Air Temperature & Tamb & 0 & 130 & 4 & 20 & 100 & 0.0813 & -32.5 \\
\hline 7 & Outdoor Ambient Air Relative Humidity & $\mathrm{RH}$ amb & 0 & 100 & 4 & 20 & 100 & 0.0625 & -25.0 \\
\hline 8 & Compressed Air Pressure & $\mathrm{PCA}$ & 0 & 200 & 4 & 20 & 100 & 0.1250 & -50.0 \\
\hline 9 & Compressed Air Flow & $\mathrm{FCA}$ & 0 & 600 & 4 & 20 & 100 & 0.3750 & -150.0 \\
\hline 10 & Electric Air Compressor kW & kW1 & 0 & 80 & 0 & 1 & 1000 & 0.0800 & 0.0 \\
\hline
\end{tabular}

Raw data collected from the data logger is saved as time stamped 15-minute data sets consisting of comma-separated variables. The order of data in the array is:

1. Array Identifier

2. Year

3. Julian Day

4. Hour-Minute

5. Seconds

6. Seconds in Data Record

7. Total Gas Use (cu ft)

8. Total Heat Recovery (gal)

9. Heat Recovery Inlet Temperature $\left({ }^{\circ} \mathrm{F}\right)$

10. Heat Recovery Outlet Temperature $\left({ }^{\circ} \mathrm{F}\right)$

11. Compressed Air Temperature $\left({ }^{\circ} \mathrm{F}\right)$

12. Outdoor Ambient Air Temperature $\left({ }^{\circ} \mathrm{F}\right)$

13. Outdoor Ambient Relative Humidity (\%RH)

14. Compressed Air Pressure (psig)

15. Compressed Air Flow (SCFM)

16. Natural Gas Flow (ACFM)

17. Heat Recovery Fluid Flow (gpm)

18. Heat Recovery Heat Transfer (Btu/Hour).

The data logger program is presented in Appendix D. 


\section{Analysis of Performance Data}

The performance of the NGEDAC was monitored between 24 April and 9 May 2002 during which time the electric motor driven Gardner-Denver air compressor was in a standby mode and operated only during periods when the NGEDAC was unavailable.

Table 29 and Figure 33 give a daily summary of operation.

During the monitoring period, the NGEDAC operated a total of 130.9 hours. Typical operation of the air compressor is 5:30 am to 5:00 p.m., Monday through Thursday, although during the monitoring period, the shop also operated on Fridays and Saturdays. The NGEDAC was put into full-time operation on April 24th at 11:00 am and operated for 5 hours that day. On 30 April the NGEDAC shut down on a fault-alarm.

During the initial "shake-down" period, beginning after the 9-10 April commissioning period, the NGEDAC shutdown on a fault-alarm on several occasions. This was traced back to an oil pressure switch and to the engine speed-control governor. This was remedied by the manufacturer.

Table 29. SIAD NGEDAC daily operation summary $-4 / 24 / 02$ to 5/9/02.

\begin{tabular}{|c|c|c|c|c|c|c|c|}
\hline Date & $\begin{array}{c}\text { Total Hours } \\
\text { of } \\
\text { Operation } \\
\text { (Hours) }\end{array}$ & $\begin{array}{l}\text { Avg. Air } \\
\text { Flow } \\
\text { (SCFM) }\end{array}$ & $\begin{array}{c}\text { Avg Gas } \\
\text { Flow } \\
\text { (CFH) }\end{array}$ & $\begin{array}{l}\text { Avg Heat } \\
\text { Recovery } \\
\text { (kBTU/Hr) }\end{array}$ & $\begin{array}{l}\text { Avg Inlet } \\
\text { Air Temp } \\
\text { (Deg. F.) }\end{array}$ & $\begin{array}{c}\text { Avg. } \\
\text { Compressed } \\
\text { Air Temp } \\
\text { (Deg. F.) } \\
\end{array}$ & $\begin{array}{c}\text { Avg. Supply } \\
\text { Pressure } \\
\text { (psig) }\end{array}$ \\
\hline 24-Apr-02 & 5.0 & 48.2 & 507.5 & 0.0 & 68.5 & 81.1 & 114.7 \\
\hline 25-Apr-02 & 10.5 & 70.2 & 506.2 & 0.0 & 70.5 & 79.5 & 102.8 \\
\hline 26-Apr-02 & 10.3 & 37.3 & 465.1 & 0.0 & 54.6 & 68.5 & 96.8 \\
\hline 27-Apr-02 & 10.0 & 38.6 & 466.2 & 46.5 & 49.1 & 71.6 & 96.0 \\
\hline 28-Apr-02 & 0.0 & & & & & & \\
\hline 29-Apr-02 & 10.5 & 58.1 & 455.9 & 0.0 & 42.8 & 64.2 & 97.7 \\
\hline 30-Apr-02 & 6.3 & 70.4 & 409.1 & 50.2 & 51.8 & 68.5 & 94.0 \\
\hline 1-May-02 & 10.5 & 69.3 & 468.7 & 0.0 & 51.5 & 71.9 & 96.5 \\
\hline 2-May-02 & 10.3 & 51.1 & 511.1 & 0.0 & 68.1 & 77.6 & 97.2 \\
\hline 3-May-02 & 9.8 & 68.7 & 497.9 & 0.0 & 69.3 & 77.1 & 91.5 \\
\hline 4-May-02 & 8.8 & 34.7 & 439.4 & 0.0 & 68.8 & 76.3 & 93.9 \\
\hline 5-May-02 & 0.0 & & & & & & \\
\hline 6-May-02 & 10.5 & 35.5 & 486.1 & 5.3 & 71.8 & 80.2 & 97.0 \\
\hline 7-May-02 & 10.5 & 54.3 & 464.1 & 0.0 & 55.0 & 70.1 & 95.6 \\
\hline 8-May-02 & 10.0 & 45.6 & 451.8 & 0.0 & 58.5 & 71.1 & 96.5 \\
\hline 9-May-02 & 8.2 & 199.4 & 721.4 & 68.7 & 68.2 & 77.2 & 92.7 \\
\hline Total & 130.9 & & & & & & \\
\hline Average & & 61.5 & 487.9 & 10.7 & 60.3 & 73.7 & 96.9 \\
\hline
\end{tabular}




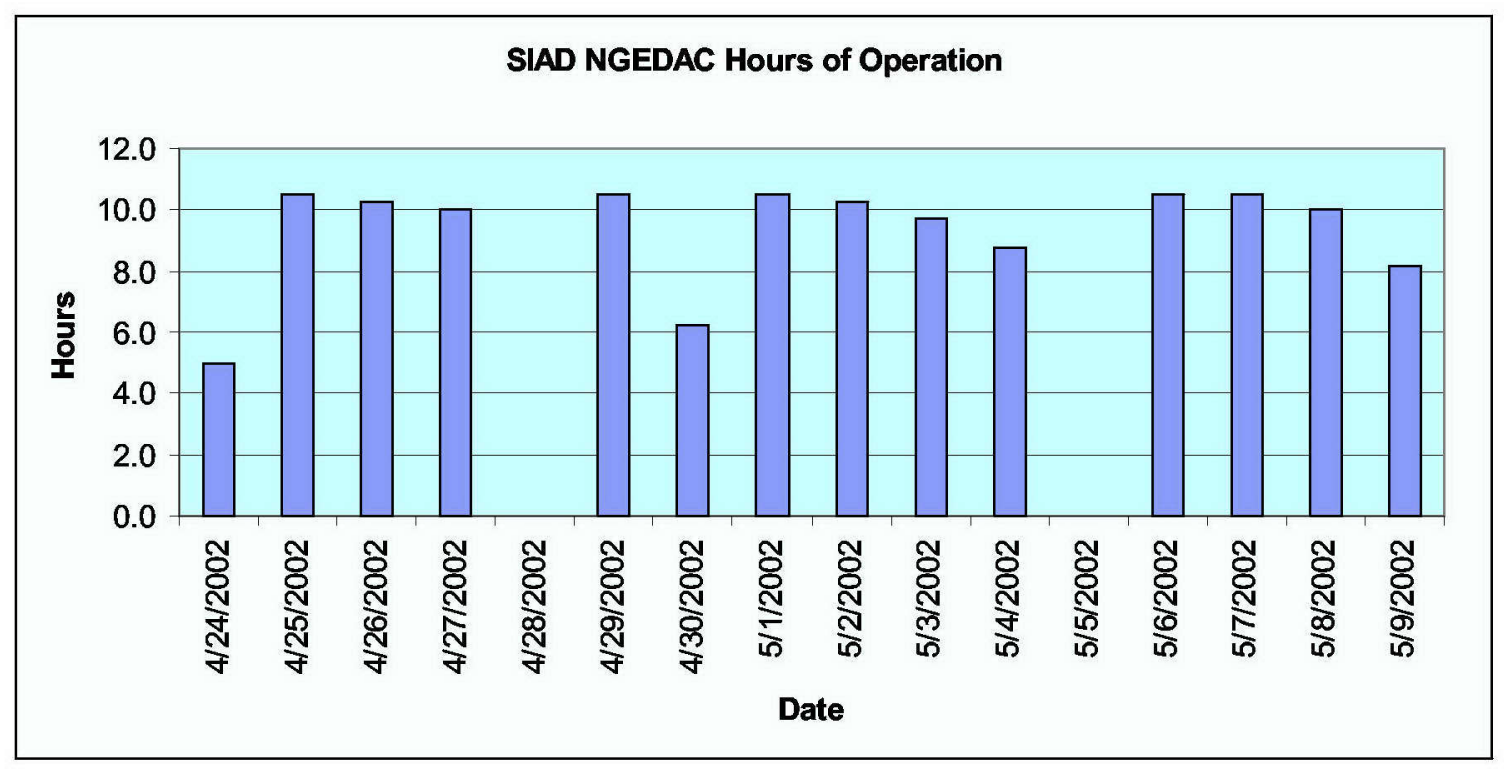

Figure 33. SIAD NGEDAC hours of operation-4/24/02 to $5 / 9 / 02$.

Figure 34 shows the summary of the process air loads during the monitoring period. The data is presented as a composite day of operation developed from the collected data. The data shows that there are periods when high compressed air loads occur but that for most of the time, the process air load is fairly low, about 61.5 SCFM, or 14 percent of design capacity. Figure 35 shows the process compressed air demand data in histogram format.

Figure 36 shows the daily average compressed air provided by the NGEDAC along with the daily average natural gas consumption rate. Since the operational data represents a fairly constant load condition for a majority of the time period, the rate of natural gas consumption does not vary significantly on a daily basis. The data presented on 9 May illustrates the higher fuel consumption, as the compressor is more fully loaded.

Figure 37 shows the daily average compressor inlet air and compressed air temperatures. The inlet temperatures were moderate during the monitoring period and the compressed air temperature prior to entering the dryer was consistently below $100^{\circ} \mathrm{F}$. 


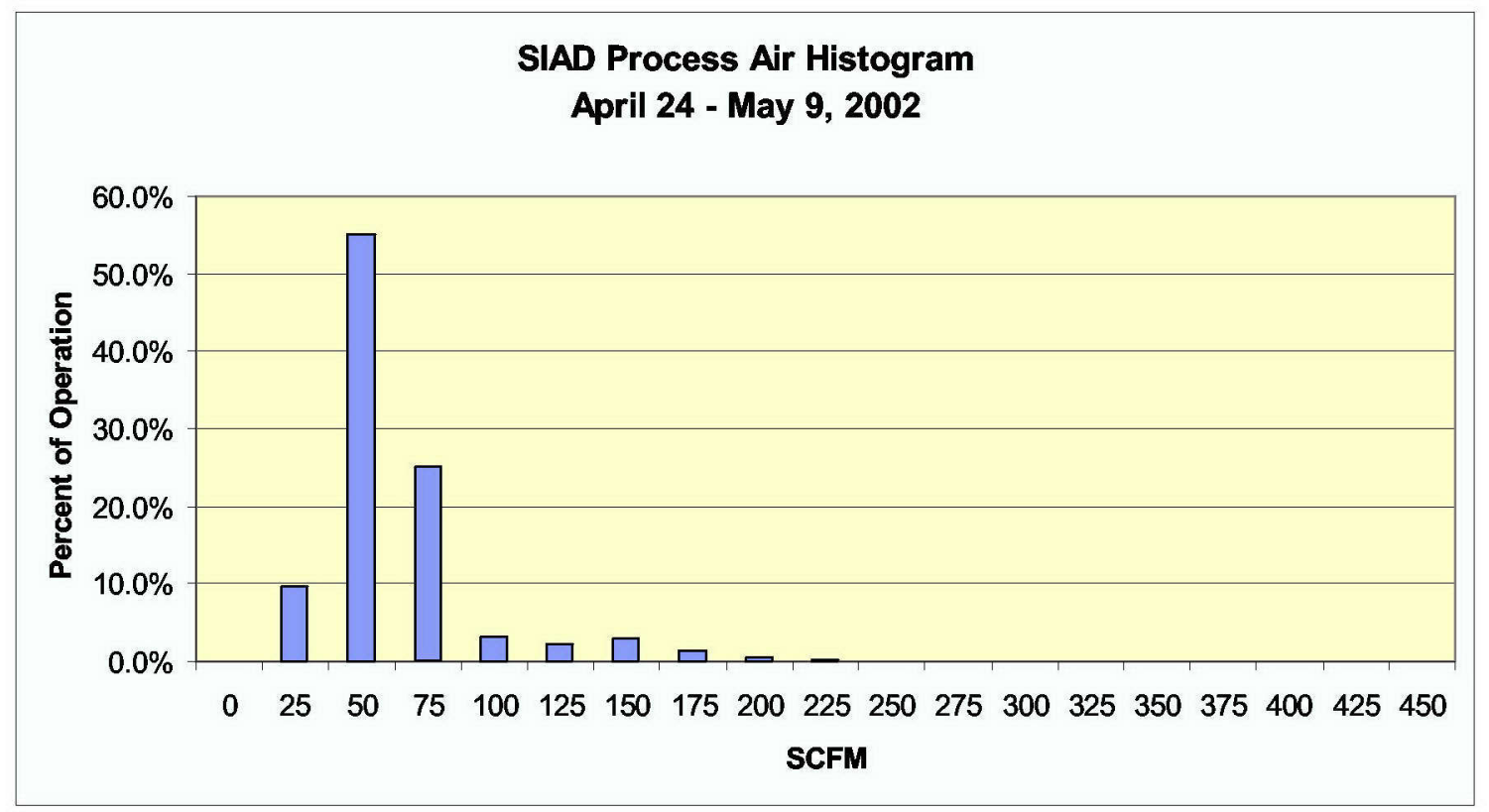

Figure 34. SIAD Process Air Demand

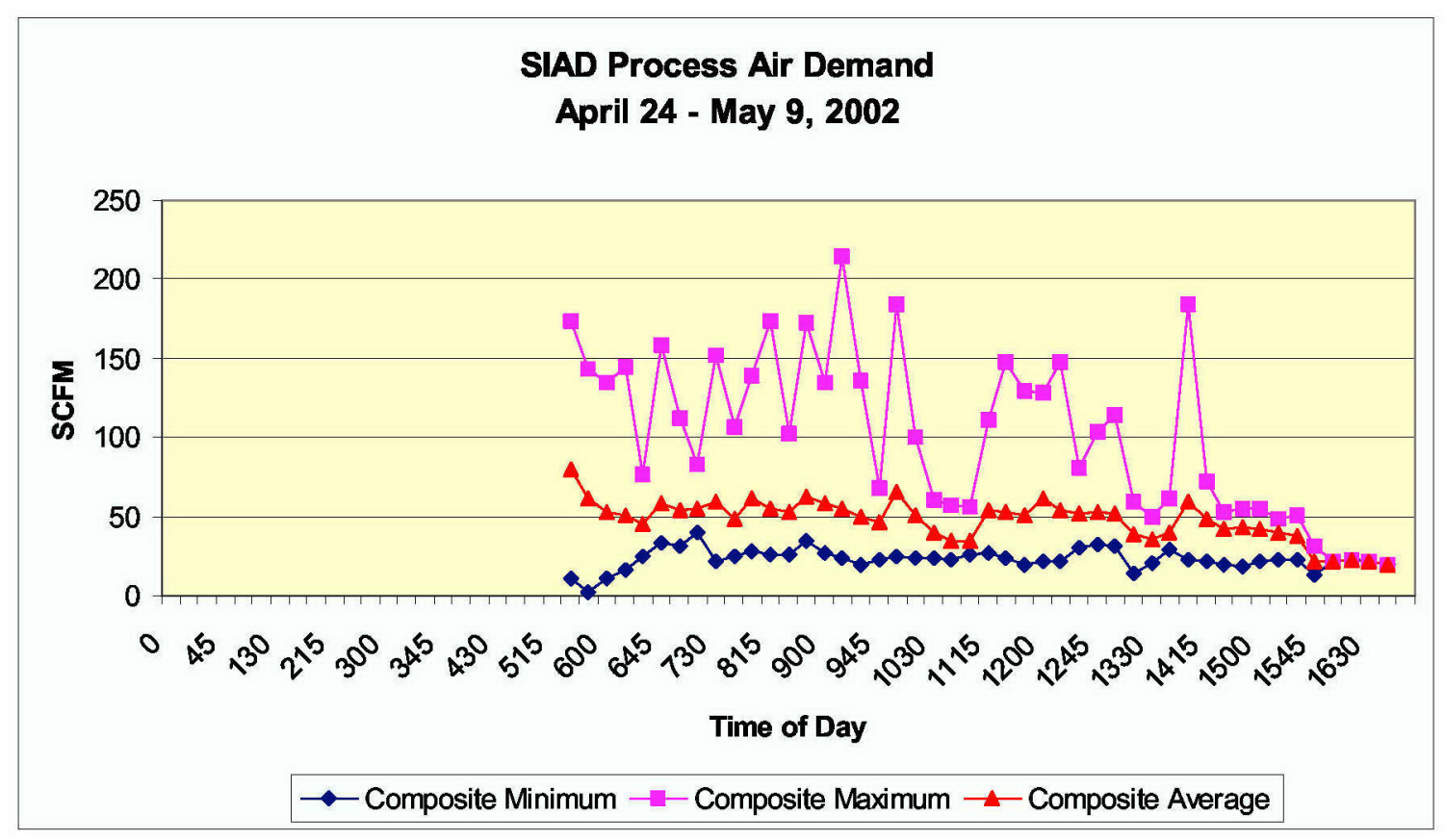

Figure 35. SIAD process air histogram. 


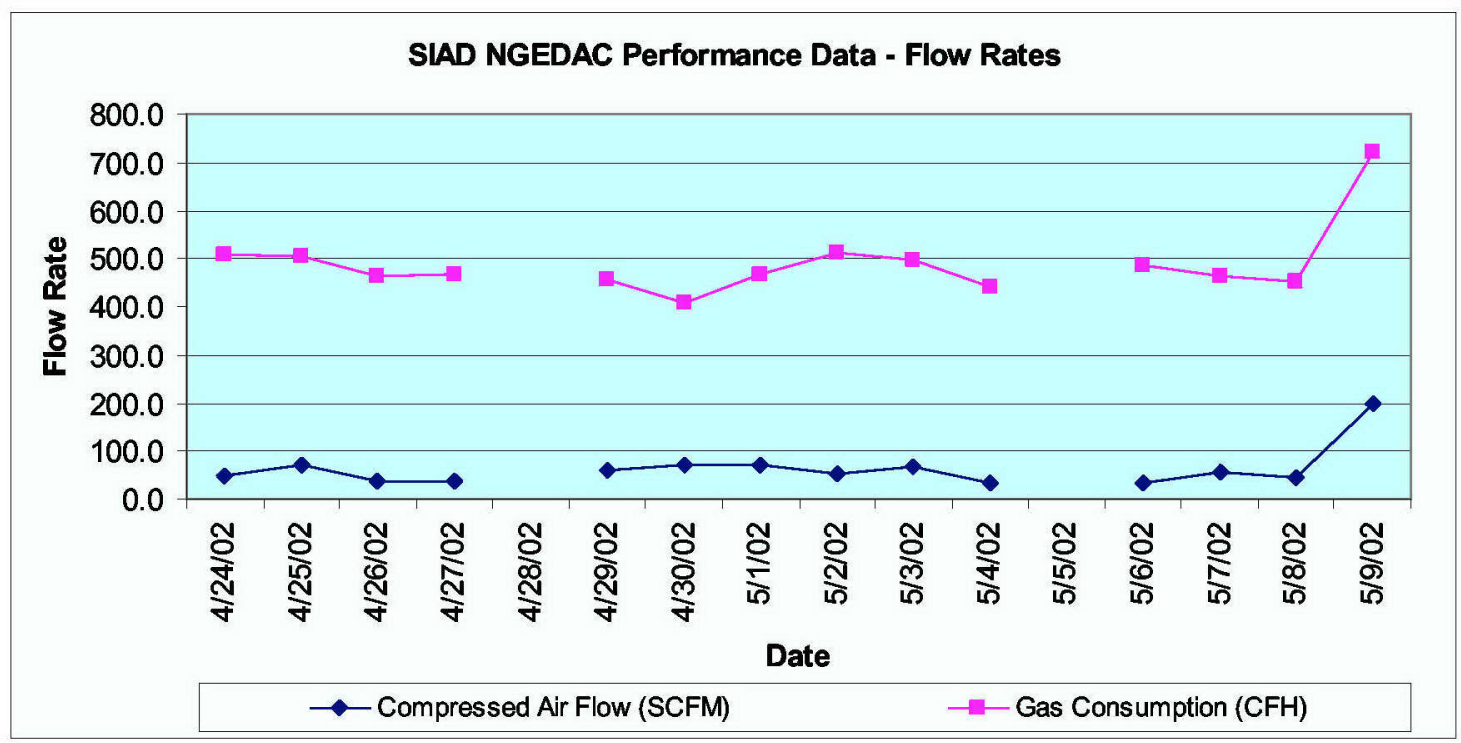

Figure 36. SIAD NGEDAC performance data - flow rates.

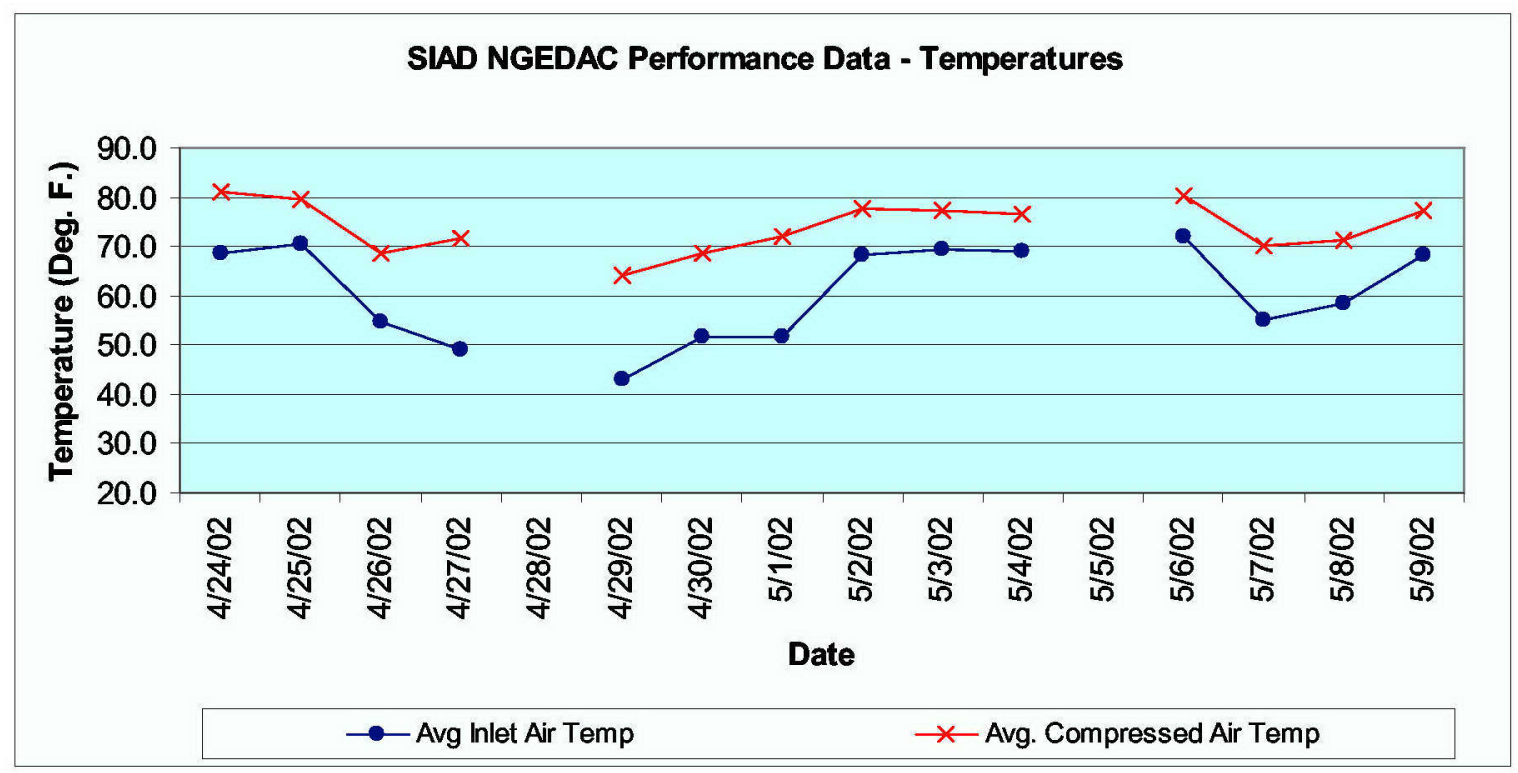

Figure 37. SIAD NGEDAC performance data - temperatures.

\section{Heat Recovery Performance}

During the monitoring period, a total of 1.7 MBtus of heat were recovered and used to heat Bldg 210 through the make-up air unit. The maximum rate of heat recovery was $260 \mathrm{kBtu} / \mathrm{hour}$. When heat recovery was taking place, the average compressed air load was $73 \mathrm{scfm}$ and the average rate of heat recovery was 156.4 $\mathrm{kBtu} / \mathrm{hour}$. The average heat recovery efficiency was 35.4 percent (heat recovered/gas consumed, based on the lower heating value of natural gas). Heat re- 
covery efficiency ranged from approximately 25 to 40 percent, with the low-end of the range reflecting the heat recovery at a full load operating condition, and the high-end of the range reflecting a low (e.g., less than 20 percent) load operating condition. Figure 38 shows the level of heat recovery versus outdoor temperature. The heat recovery system was designed to provide heat (activate the circulating pump in the heat recovery loop) whenever the compressor was on, the make-up air unit was on, and the outdoor temperature was $60^{\circ} \mathrm{F}$ or lower. Note that the heat recovery did not occur during all times when the temperature was below $60^{\circ} \mathrm{F}$, due to a circuit breaker adjustment problem that prevented pump operation.

The average flow rate of the heat recovery hydronic loop was $18.3 \mathrm{gal} / \mathrm{minute}$. The average fluid temperature compressor leaving was $109.1^{\circ} \mathrm{F}$ with a maximum temperature of $132^{\circ} \mathrm{F}$. The average return temperature of the fluid was $90.6^{\circ} \mathrm{F}$ and the maximum return temperature was $106.2^{\circ} \mathrm{F}$.

\section{NGEDAC Performance}

On 9 May 2002, the operational performance data were collected on the NGEDAC at four specified compressor loads of 25, 50, 75, and 100 percent of maximum design load. The monitoring system was modified to develop 5-minute data records during this time. Table 30 summarizes the results, along with a 10 percent compressor load operating point taken during another time period.

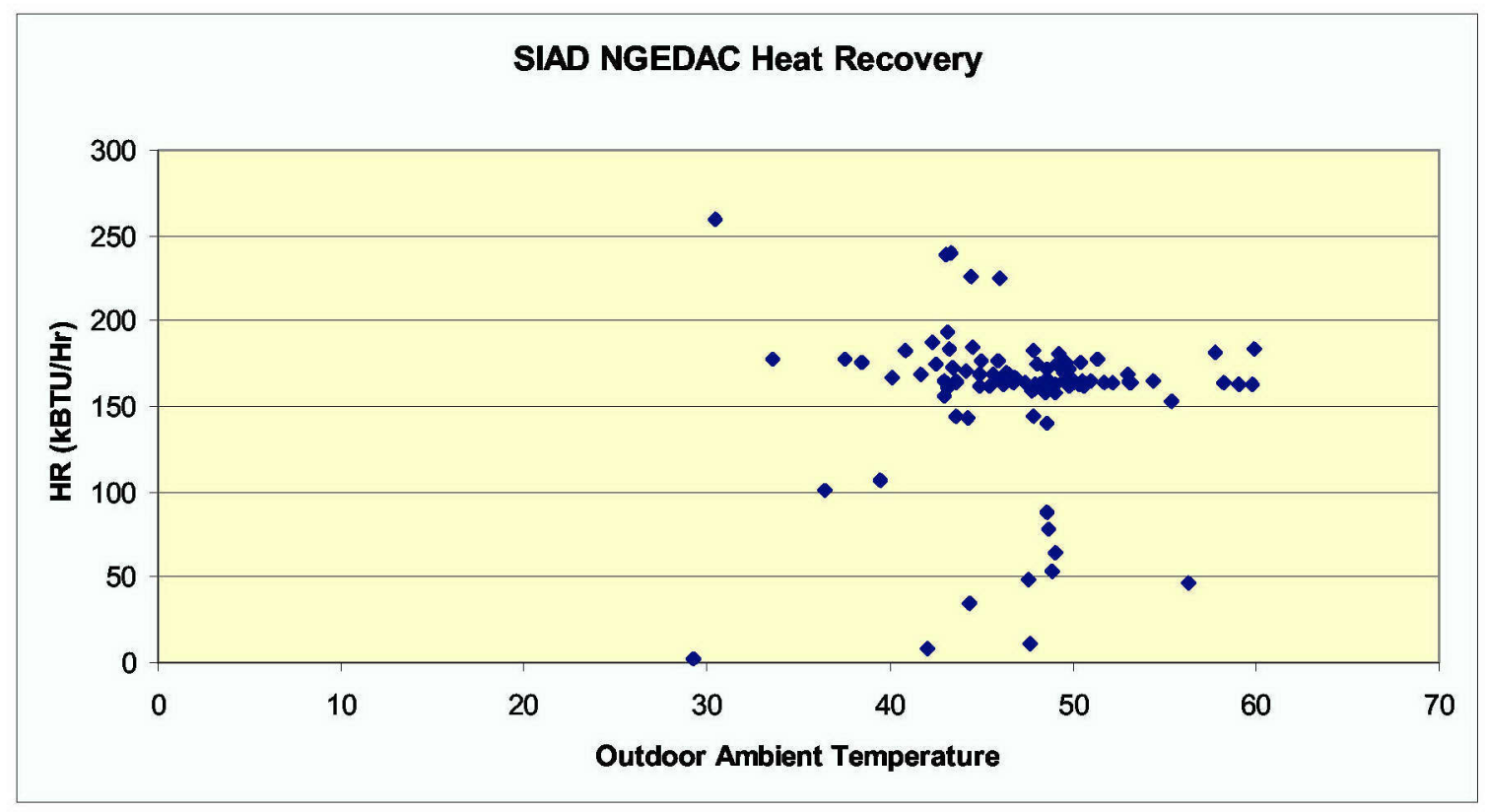

Figure 38. SIAD NGEDAC heat recovery. 
Table 30. SIAD NGEDAC performance summary.

\begin{tabular}{|c|c|c|c|c|c|}
\hline \multicolumn{6}{|c|}{ Natural Gas Engine-Driven Air Compressor Performance Summary } \\
\hline \multicolumn{2}{|c|}{ Defined Operating Points } & \multicolumn{3}{|c|}{ Measured } & \multirow{2}{*}{$\begin{array}{l}\text { Calculated } \\
\text { SCFM }_{\text {Air }} / \text { CFM }_{\text {NG }}\end{array}$} \\
\hline $\begin{array}{l}\text { Percent } \\
\text { Loaded }\end{array}$ & $\begin{array}{l}\text { Corresponding } \\
\text { (SCFM) }\end{array}$ & $\begin{array}{l}\text { Air Flow } \\
\text { (SCFM) }\end{array}$ & $\begin{array}{l}\text { Gas Flow } \\
\text { (CFH) }\end{array}$ & $\begin{array}{c}\text { Period } \\
\text { (Minutes) }\end{array}$ & \\
\hline $100 \%$ & 450.0 & 450.43 & 1070.9 & 70 & 25.24 \\
\hline $75 \%$ & 337.5 & 337.16 & 1038.0 & 55 & 19.49 \\
\hline $50 \%$ & 225.0 & 227.40 & 715.0 & 50 & 19.08 \\
\hline $25 \%$ & 112.5 & 121.46 & 530.6 & 25 & 13.74 \\
\hline $10 \%$ & 45.0 & 45.40 & 453.7 & - & 6.00 \\
\hline
\end{tabular}

Figure 39 shows the relationship between the compressed air supplied and the energy requirements of the NGEDAC (energy equivalent of the hourly gas consumption based on the lower heating value of natural gas $-905 \mathrm{Btu} / \mathrm{cu} \mathrm{ft}$ ).

The graph shows that performance below 50 percent load (225 SCFM) tracks closely with the manufacturer's projected energy requirement, and is actually a little better (lower energy consumption) than anticipated. However, the energy requirement is fairly flat in the range of 75 to 100 percent design load (337.5 SCFM - 450 SCFM), and higher than the manufacturer's specifications (Manufacturer Spec curve) in this range. This was an unexpected result since the first stage of unloading for the compressor package is supposed to be the modulation (reduction) of the engine speed, which would result in a lower rate of fuel consumption. SAIC contacted Gascom to discuss this finding. Gascom indicated that this appeared to be the result of the pressure sensor that had a wider thandesired dead band around the set point. Gascom replaced the pressure sensor with a different transducer to resolve this situation on 31 May 2002.

Data collected on 31 May 2002 indicates that the change to the new transducer did improve the performance as predicted. At 75 percent design air flow, the gas consumption dropped from $1038 \mathrm{scfh}$ to about $827 \mathrm{scfh}$, which is equal to the manufacturer's specifications (Figure 40). Table 31 lists composite performance information, combining the low flow rate data points from the 9 May runs and the higher flow rate data points taken on 31 May. This reflects the best estimate of the NGEDAC's performance characteristics across its full operating regime. 


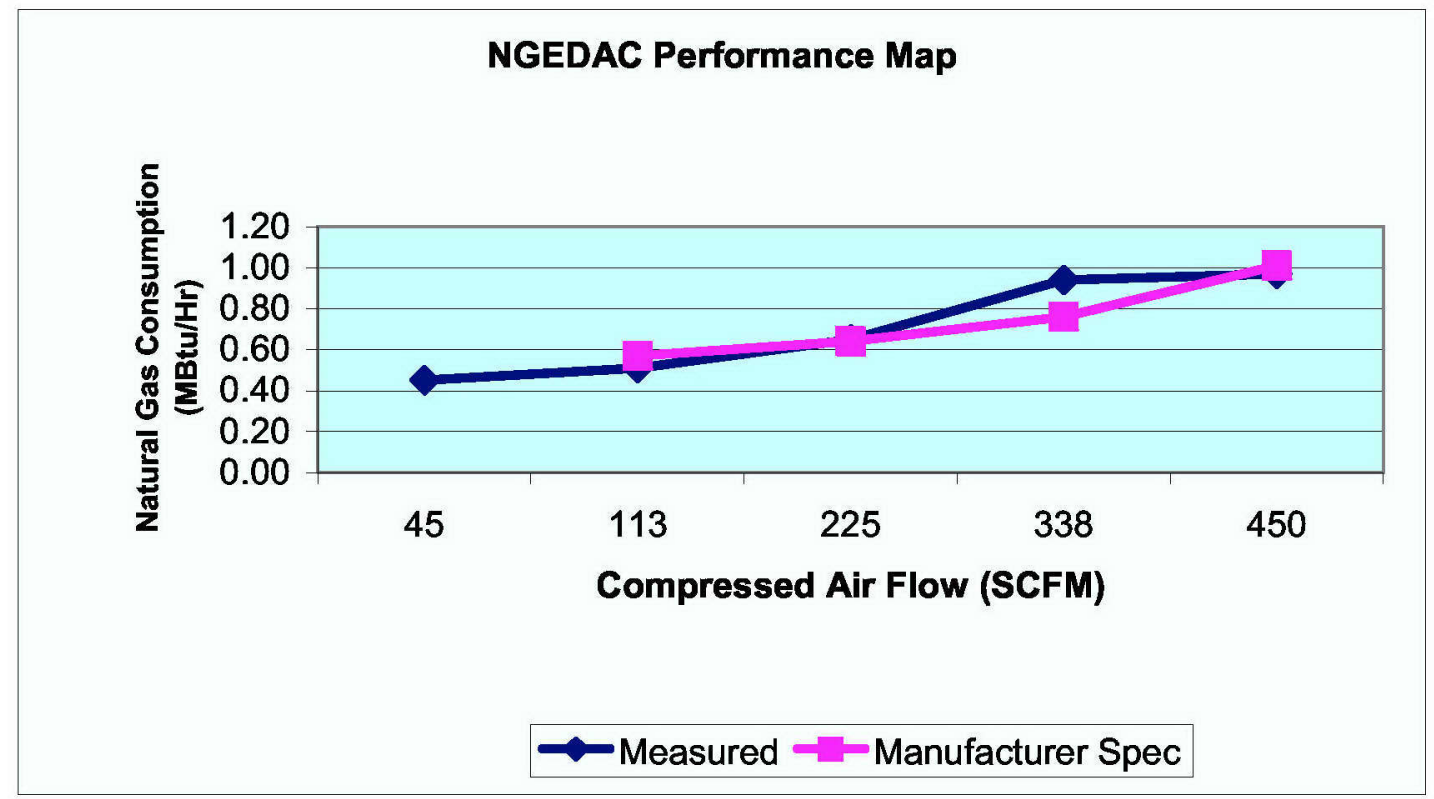

Figure 39. SIAD NGEDAC performance map (reference: Manufacturer Spec. - Gascom Memo 10/29/001 M. Bloemen to K. Frekovich).

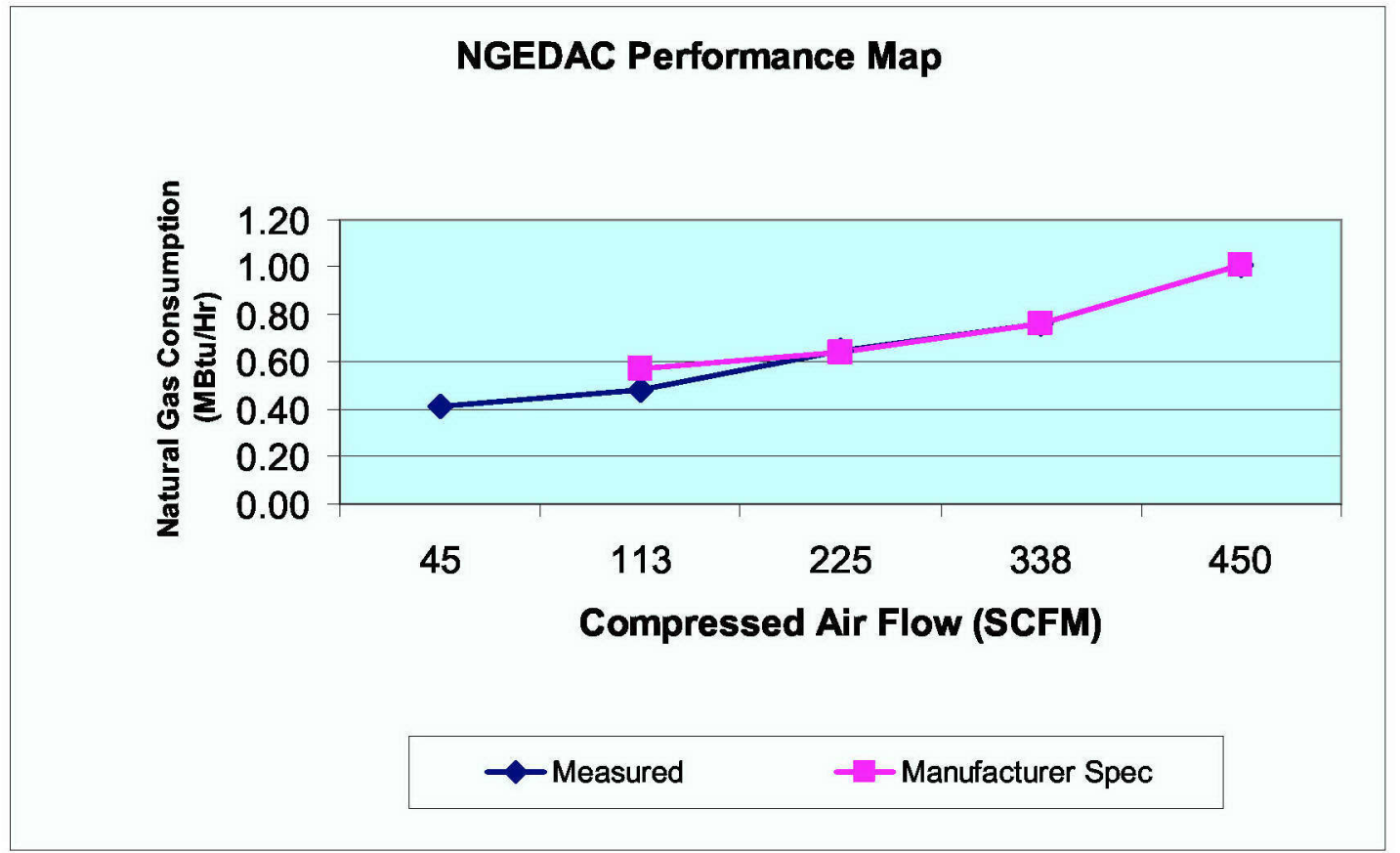

Figure 40. Revised SIAD NGEDAC performance map. 
Table 31. NGEDAC composite performance data based on 9 May and 31 May monitoring.

\begin{tabular}{|r|r|r|r|}
\hline $\begin{array}{l}\text { \% Of Full } \\
\text { Load }\end{array}$ & $\begin{array}{l}\text { Air Flow } \\
\text { (SCFM) }\end{array}$ & $\begin{array}{c}\text { Gas Consumption } \\
\text { (SCFH) }\end{array}$ & \multicolumn{2}{|c|}{$\begin{array}{c}\text { Gas Energy } \\
\text { (MBtu/Hr - } \\
\text { LHV) }\end{array}$} \\
\hline $10 \%$ & 45 & 453.7 & 0.41 \\
$20 \%$ & 90 & 489.6 & 0.44 \\
$30 \%$ & 135 & 549 & 0.50 \\
$40 \%$ & 180 & 632 & 0.57 \\
$50 \%$ & 225 & 715 & 0.65 \\
$60 \%$ & 270 & 761.5 & 0.69 \\
$70 \%$ & 315 & 807.9 & 0.73 \\
$80 \%$ & 360 & $1,000.0$ & 0.91 \\
$90 \%$ & 405 & $1,055.8$ & 0.96 \\
$100 \%$ & 450 & $1,111.7$ & 1.01 \\
\hline
\end{tabular}

\section{Comparative Analysis}

Using the performance data collected from both the existing electric motor driven air compressor and the new natural gas engine-driven air compressor along with SIAD's energy rates, process air loads, hours of operation, actual installed costs, and actual maintenance costs-the energy and economics of the NGEDAC were analyzed.

\section{Model Inputs}

Table 32 lists the system values input into the model. Note that the initial analysis is based on a retrofit application where a new NGEDAC is compared to an existing electric air compressor that is still functional. Therefore the cost differential between the two systems is the total installed cost of the NGEDAC.

The performance maps of the two air compressors were based on the performance data for each unit as measured in the field. Figure 41 shows the two performance curves. The scale on the left should be used for the NGEDAC and that on the right for the electric motor driven air compressor.

The operation of the units was based on the consolidated process air load data obtained during the September and April monitoring periods. Note that the load profile is for process air only, and does not include the breathing air demand. 


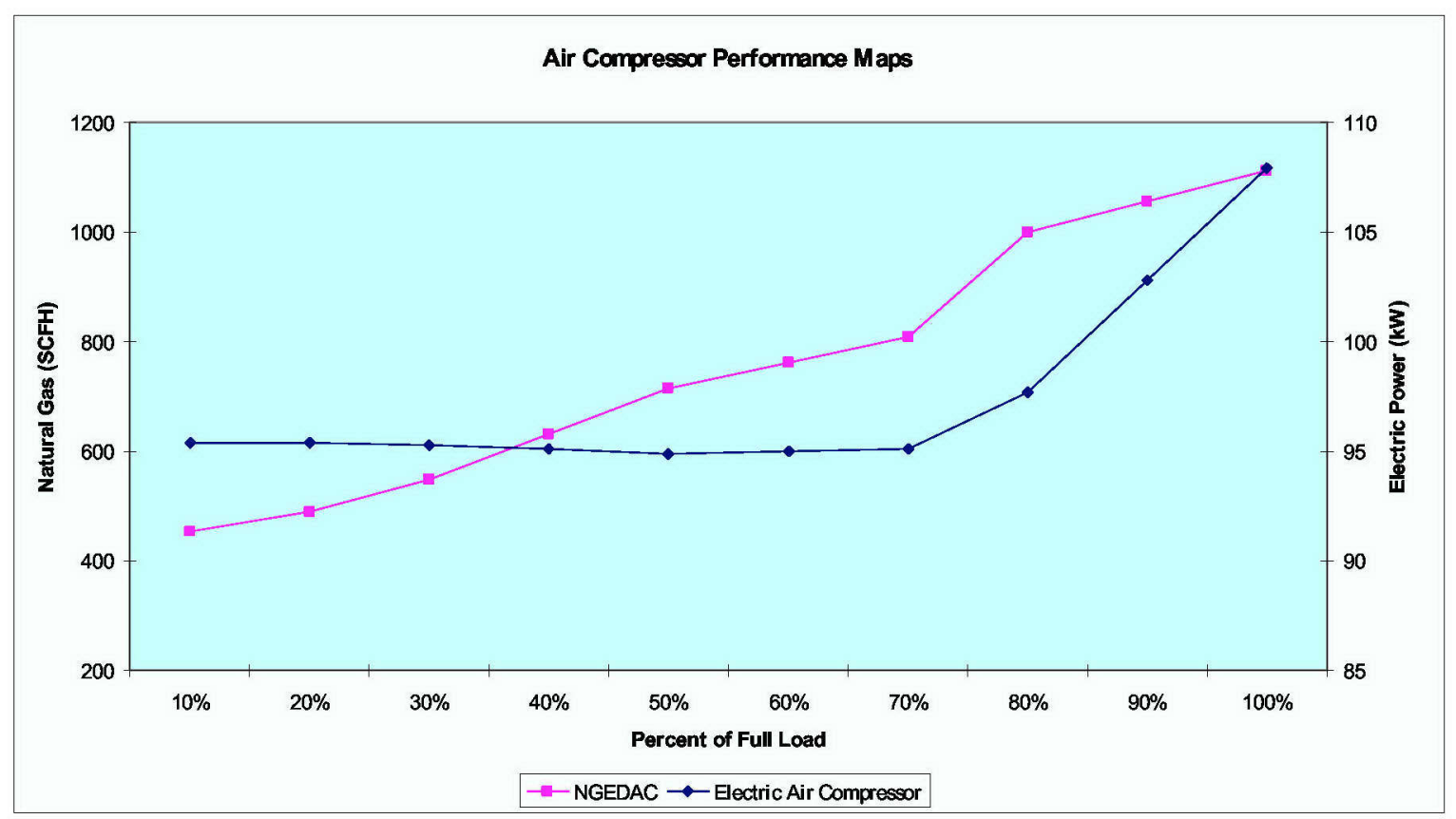

Figure 41. SIAD NGEDAC and electric air compressor performance maps.

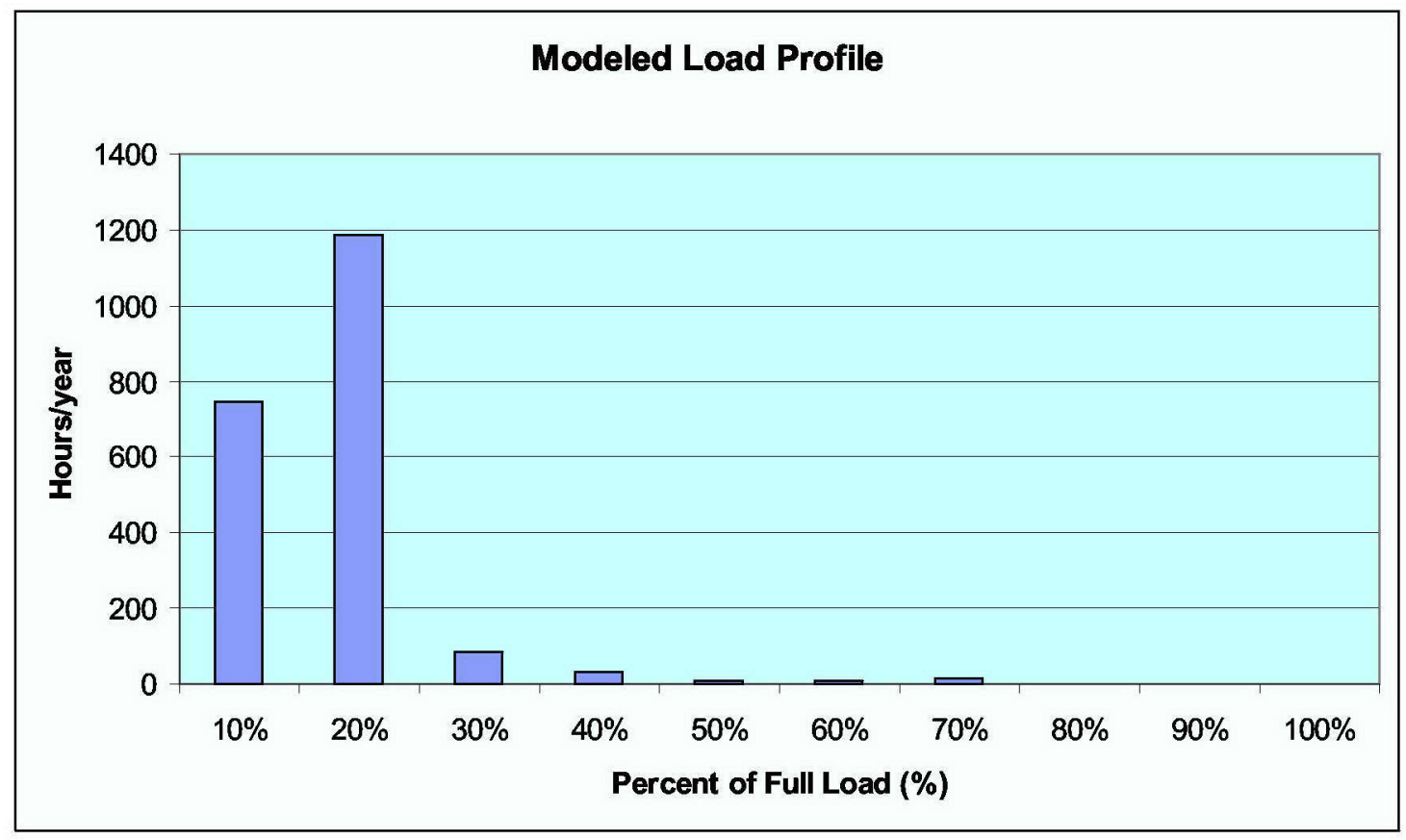

Figure 42. SIAD typical process air loads. 
Table 33. Energy and cost savings-NGEDAC vs. electric air compressor.

\begin{tabular}{|c|c|c|c|}
\hline $\begin{array}{l}\text { Annual Energy Use and Peak } \\
\text { Demand }\end{array}$ & $\begin{array}{l}\text { Electric Air } \\
\text { Compressor }\end{array}$ & NGEDAC & Savings \\
\hline Energy Use & $\begin{array}{l}198,341 \mathrm{kWh} \\
108.4 \mathrm{~kW}\end{array}$ & $\begin{array}{c}1,456 \mathrm{kWh} \text { heat } \\
\text { recovery } \\
1021 \text { MBtu gas } \\
\text { engine } \\
\text { (283) MBtu heat } \\
\text { recovery } \\
1.07 \text { MBtuh }\end{array}$ & $\begin{array}{l}196,885 \mathrm{kWh} \\
(738) \mathrm{MBtu} \\
95 \mathrm{~kW}-108 \mathrm{~kW}\end{array}$ \\
\hline $\begin{array}{l}\text { Annual Operating and Maintenance } \\
\text { Costs }\end{array}$ & $\begin{array}{l}\text { Electric Air } \\
\text { Compressor }\end{array}$ & NGEDAC & Savings \\
\hline $\begin{array}{l}\text { Natural Gas } \\
\text { Electricity } \\
\text { Heat Recovery } \\
\text { Maintenance }\end{array}$ & $\begin{array}{r}\$ 0 \\
\$ 29,460 \\
\$ 0 \\
\$ 1,007\end{array}$ & $\begin{array}{r}\$ 3,150 \\
\$ 212 \\
(\$ 873) \\
\$ 1,983\end{array}$ & $\begin{array}{r}(\$ 3,150) \\
\$ 29,248 \\
\$ 873 \\
(\$ 976)\end{array}$ \\
\hline Total & $\overline{\$ 30,467}$ & $\$ 4,472$ & $\$ 225,995$ \\
\hline
\end{tabular}

The cost of air delivered by the NGEDAC is $\$ 0.45$ per thousand cu $\mathrm{ft}(\mathrm{kcf})$, while the cost of air for the electric air compressor is $\$ 3.05 / \mathrm{kcf}$. At an installed cost of $\$ 222,135$ for the NGEDAC, the simple payback for the SIAD application is 8.5 years.

\section{Heat Recovery Economics}

The heat recovery net contribution toward the operating cost savings is about $\$ 661$, which includes an offset of $\$ 873$ in natural gas used for boiler fuel minus $\$ 212$ to operate the heat recovery loop circulating pump. Table 34 lists the cost for implementing the heat recovery.

Table 34. Cost for implementing heat recovery.

\begin{tabular}{|l|r|}
\hline Item & \multicolumn{1}{|c|}{ Cost } \\
\hline Heat Exchangers on Compressor & $\$ 5950$ \\
\hline Pre-Heat Coil in Make-Up Air Unit & $\$ 1032$ \\
\hline Circulating Pump (1.5 HP) & $\$ 1050$ \\
\hline Propylene Glycol (45 Gallons) & $\$ 935$ \\
\hline Pot Feeder/Nalve/Vents, etc. & $\$ 439$ \\
\hline Hot Water Piping/Insulation (400 feet) & $\$ 6869$ \\
\hline Controls/Electrical (Pro-rated estimate) & $\$ 500$ \\
\hline Total & $\$ 16,775$ \\
\hline
\end{tabular}


This results in a simple payback for heat recovery of 25.4 years. The heat recovery would be much more attractive if the application was year-round, rather than winter time only, or if the NGEDAC was operated at full load. For example, at full load operation, it is estimated that heat recovery system would provide 66 percent more usable heat (ratio of $260 \mathrm{kBtuh} / 156 \mathrm{k}$ Btuh), would save about $\$ 1252$ (\$1464 gas savings; $\$ 212$ electricity used) annually, and have a simple payback of 13.4 years.

\section{Economics of New/Replacement vs. Retrofit Application}

In considering an application where a new compressor is needed-either to replace an existing unit or to add capacity - then the capital costs of both the electric motor driven air compressor and the NGEDAC would need to be considered. For the case of SIAD, a new 125 HP electric motor driven air compressor would cost approximately $\$ 68,000$ ( $\$ 46,000$ capital equipment and $\$ 22,000$ installation cost). The cost differential between the NGEDAC and the electric air compressor would be reduced to $\$ 154,135(\$ 222,135-\$ 68,000)$, and the resulting simple payback period would be reduced to 5.9 years (Table 35 ).

\section{Sensitivity Analysis}

A series of sensitivity analyses were conducted for the retrofit results. The analysis looks at the effect of annual savings, simple payback, net present value and internal rate of return for the retrofit application as the cost of both natural gas and electricity change. The analysis includes the base case scenario with $\$ 0.149 / \mathrm{kWh}$ electricity and $\$ 3.09 / \mathrm{MBtu}$ natural gas. The cost of electricity ranges from $\$ 0.08 / \mathrm{kWh}$ to $\$ 0.20 / \mathrm{kWh}$. The natural gas costs range from $\$ 2.00 / \mathrm{MBtu}$ to $\$ 10.00 / \mathrm{MBtu}$. Table 36 and Figure 43 give the information that allows SIAD staff to evaluate the economics of the NGEDAC on an ongoing basis as energy costs change, assuming all other variables remain the same (e.g., loads, maintenance costs, etc.). The results of the analysis for annual savings are presented below.

Table 35. Economics of new/replacement vs. retrofit application.

\begin{tabular}{|l|c|c|c|}
\hline \multicolumn{1}{|c|}{ Application } & $\begin{array}{c}\text { Simple } \\
\text { Payback } \\
\text { (vears) }\end{array}$ & $\begin{array}{l}\text { Internal Rate of } \\
\text { Return (\%) }\end{array}$ & $\begin{array}{c}\text { Net Present } \\
\text { Value (\$) }\end{array}$ \\
\hline Retrofit & 8.5 & 10 & $\$ 154,093$ \\
New/Replacement & 5.9 & 12.8 & $\$ 222,093$ \\
\hline
\end{tabular}


Table 36. Annual savings sensitivity-gas/electric price changes.

\begin{tabular}{|c|c|c|c|c|c|}
\hline & \multicolumn{5}{|c|}{ Annual System Savings (\$/year) } \\
\cline { 2 - 6 } & \multicolumn{5}{|c|}{ Gas Price (\$/MBtu) } \\
\hline $\begin{array}{c}\text { Electricity Price } \\
\text { (cents/kWh) }\end{array}$ & 2.0 & 3.1 & 5.0 & 7.0 & 10.0 \\
\hline $\mathbf{8 . 0}$ & $\$ 13,298$ & $\$ 12,496$ & $\$ 11,082$ & $\$ 9,605$ & $\$ 7,390$ \\
10.0 & $\$ 17,236$ & $\$ 16,433$ & $\$ 15,020$ & $\$ 13,543$ & $\$ 11,328$ \\
12.0 & $\$ 21,173$ & $\$ 20,371$ & $\$ 18,958$ & $\$ 17,481$ & $\$ 15,265$ \\
14.9 & $\$ 26,794$ & $\$ 25,995$ & $\$ 24,579$ & $\$ 23,102$ & $\$ 20,886$ \\
18.0 & $\$ 32,986$ & $\$ 32,184$ & $\$ 30,771$ & $\$ 29,294$ & $\$ 27,078$ \\
$\mathbf{2 0 . 0}$ & $\$ 36,924$ & $\$ 36,122$ & $\$ 34,709$ & $\$ 33,232$ & $\$ 31,016$ \\
\hline
\end{tabular}

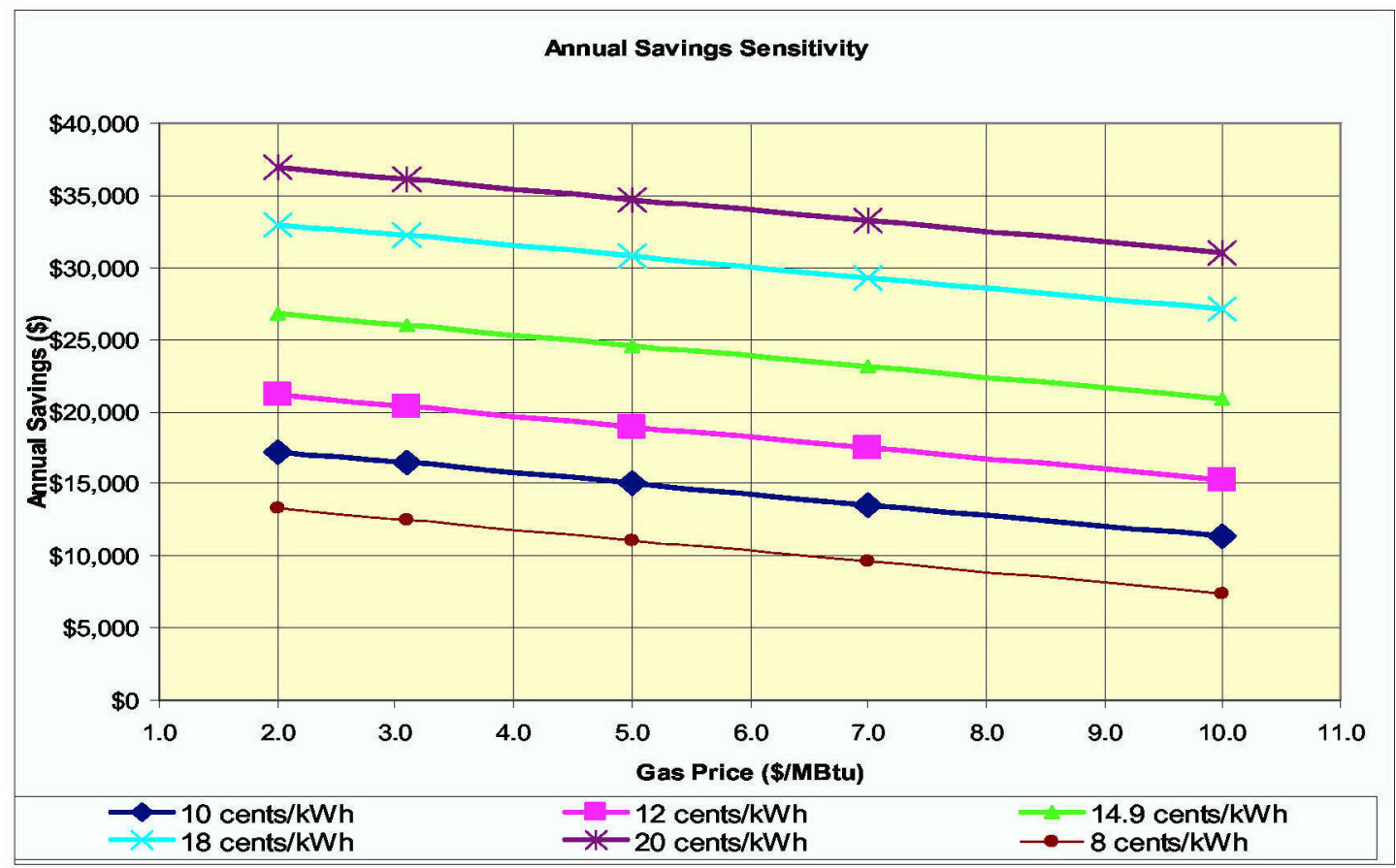

Figure 43. Annual savings sensitivity-gas/electric price changes.

The annual savings will be as low as $\$ 7,390$ when natural gas is $\$ 10.00 / \mathrm{MBtu}$ and electricity is $\$ 0.08 / \mathrm{kWh}$. The savings will be as high as $\$ 36,820 /$ year when natural gas is $\$ 2.00 / \mathrm{MBtu}$ and electricity is $\$ 0.20 / \mathrm{kWh}$ Table 37 and Figure 44 give the results of the sensitivity analysis for simple payback.

The simple payback could be as low as 6 years when natural gas is $\$ 2.00 / \mathrm{MBtu}$ and electricity is $\$ 0.20 / \mathrm{kWh}$. The simple payback could be as high as 30 years when natural gas is $\$ 10.00 / \mathrm{MBtu}$ and electricity is $\$ 0.08 / \mathrm{kWh}$. As the cost of natural gas decreases and the cost of electricity increases, the simple payback for the project decreases. Table 38 and Figure 45 give the results of the sensitivity analysis for net present value. 
Table 37. Simple payback sensitivity—gas/electric price changes.

\begin{tabular}{|c|c|c|c|c|c|}
\hline & \multicolumn{5}{|c|}{ Simple Payback (years) } \\
\hline & \multicolumn{5}{|c|}{ Gas Price (\$/MBtu) } \\
\hline $\begin{array}{c}\text { Electricity Price } \\
\text { (cents/kWh) }\end{array}$ & 2.0 & 3.1 & 5.0 & 7.0 & 10.0 \\
\hline $\mathbf{8 . 0}$ & 16.7 & 17.8 & 20.0 & 23.1 & 30.1 \\
10.0 & 12.9 & 13.5 & 14.8 & 16.4 & 19.6 \\
12.0 & 10.5 & 10.9 & 11.7 & 12.7 & 14.6 \\
14.9 & 8.3 & 8.5 & 9.0 & 9.6 & 10.6 \\
18.0 & 6.7 & 6.9 & 7.2 & 7.6 & 8.2 \\
20.0 & 6.0 & 6.1 & 6.4 & 6.7 & 7.2 \\
\hline
\end{tabular}

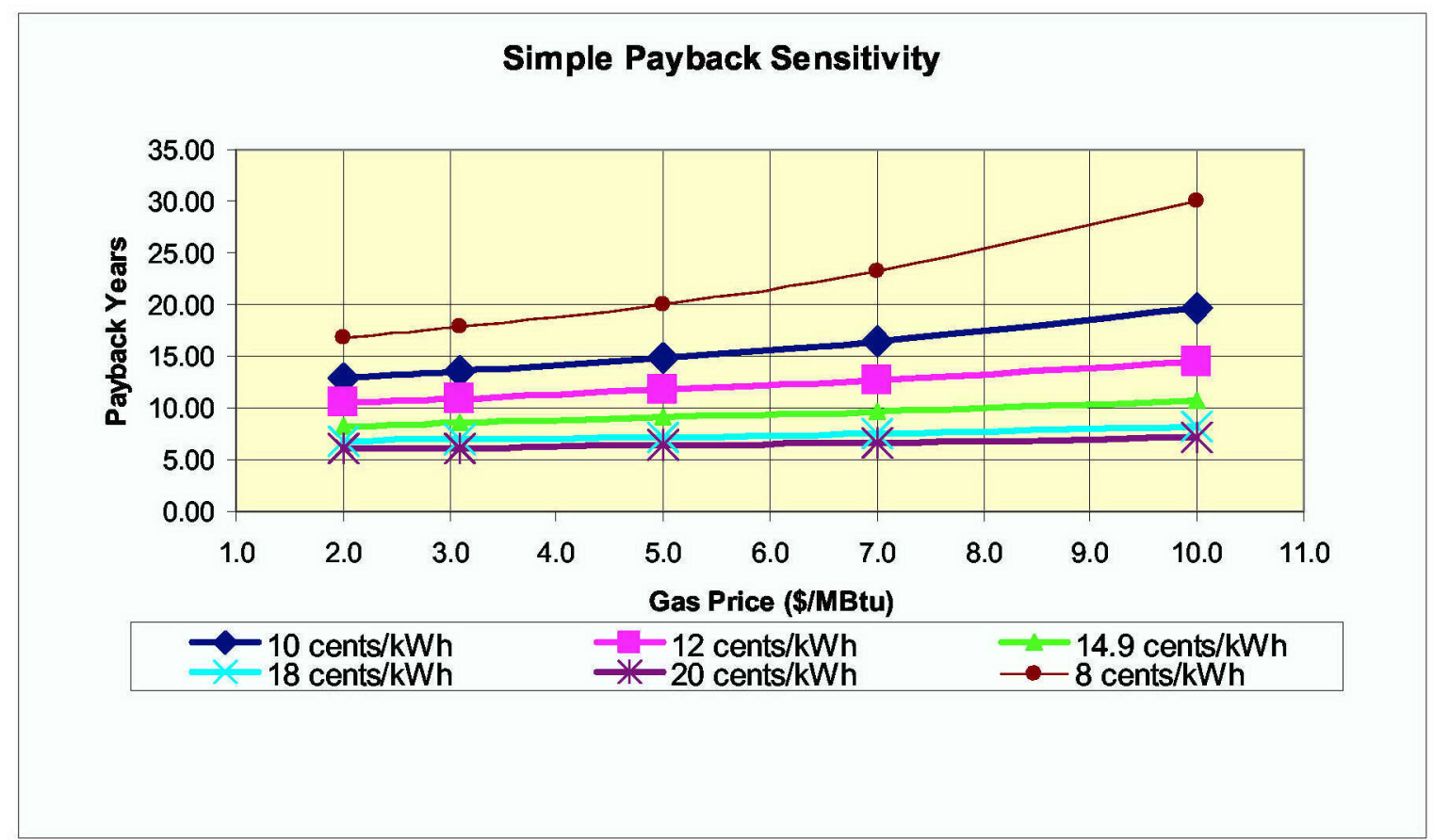

Figure 44. Simple payback sensitivity-gas/electric price changes.

The project would have a negative NPV if electricity was $\$ 0.08 / \mathrm{kWh}$ or if the price of electricity was $\$ 0.10 / \mathrm{kWh}$ and the cost of natural gas was greater than $\$ 3.25 / \mathrm{MBtu}$. Figure 46 gives the results of the sensitivity analysis for internal rate of return. 
Table 38. Net present value sensitivity—gas/electric price changes.

\begin{tabular}{|c|r|r|r|r|r|}
\hline & \multicolumn{5}{|c|}{ Net Present Value (\$) } \\
\hline & \multicolumn{5}{|c|}{ Gas Price (\$/MBtu) } \\
\hline $\begin{array}{c}\text { Electricity Price } \\
\text { (cents/kWh) }\end{array}$ & \multicolumn{1}{|c|}{2.0} & \multicolumn{1}{|c|}{3.1} & \multicolumn{1}{|c|}{5.0} & \multicolumn{1}{c|}{7.0} & \multicolumn{1}{c|}{10.0} \\
\hline 8.0 & $-\$ 29,672$ & $-\$ 41,279$ & $-\$ 61,744$ & $-\$ 83,121$ & $-\$ 115,179$ \\
\hline 10.0 & $\$ 27,323$ & $\$ 15,701$ & $-\$ 4,749$ & $-\$ 26,126$ & $-\$ 58,184$ \\
12.0 & $\$ 84,303$ & $\$ 72,696$ & $\$ 52,246$ & $\$ 30,869$ & $-\$ 1,203$ \\
\hline 14.9 & $\$ 165,657$ & $\$ 154,093$ & $\$ 133,599$ & $\$ 112,222$ & $\$ 80,150$ \\
18.0 & $\$ 255,274$ & $\$ 243,667$ & $\$ 223,216$ & $\$ 201,839$ & $\$ 169,767$ \\
20.0 & $\$ 312,269$ & $\$ 300,661$ & $\$ 280,211$ & $\$ 258,834$ & $\$ 226,762$ \\
\hline
\end{tabular}

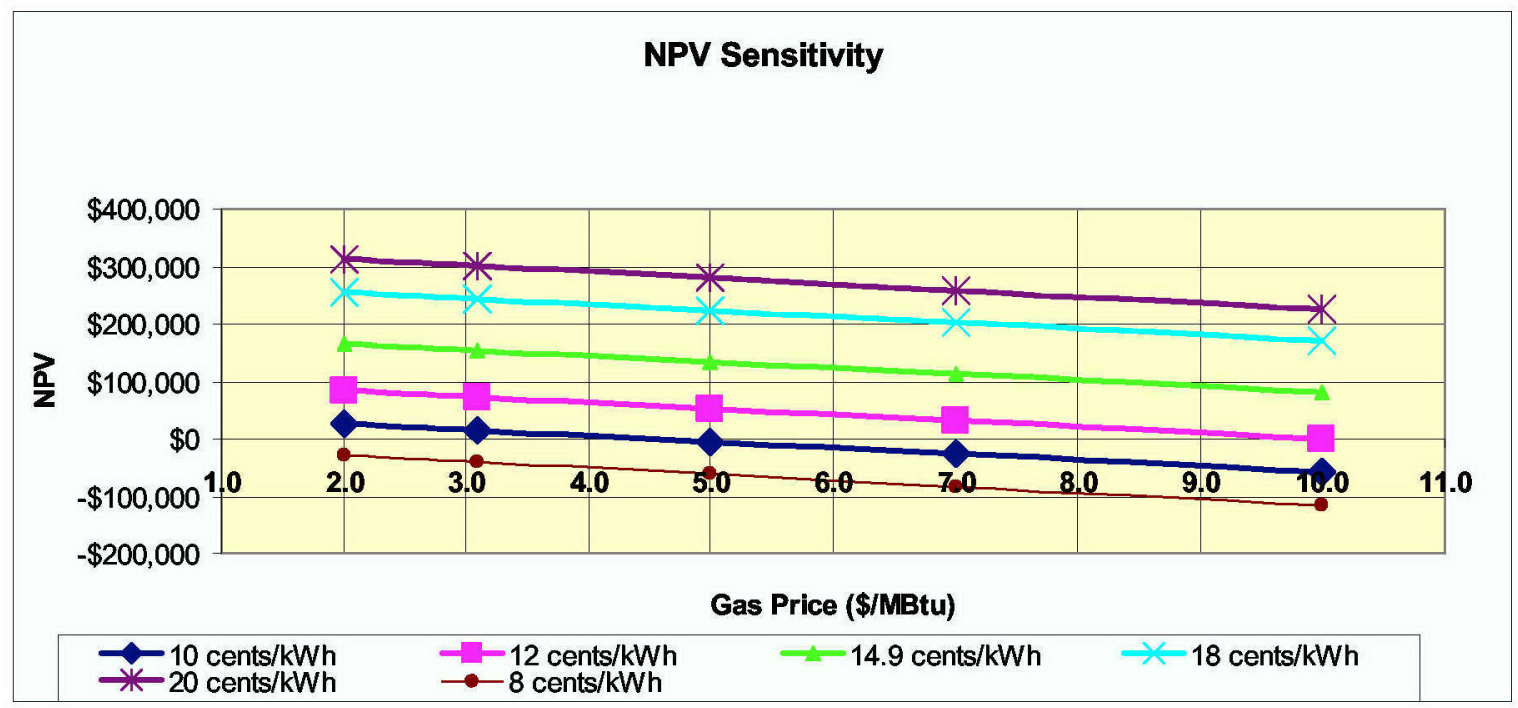

Figure 45. Net present value sensitivity-gas/electric price changes.

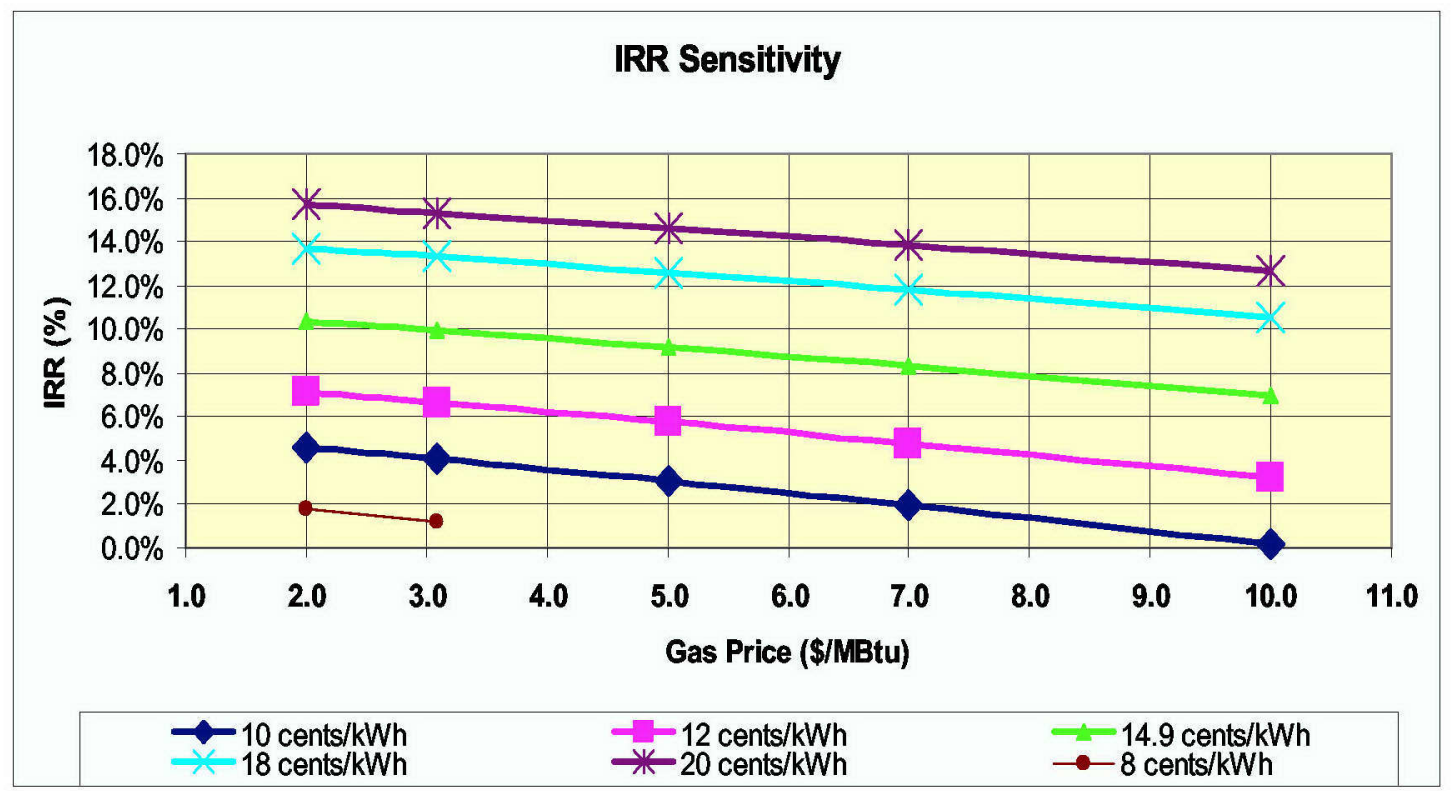

Figure 46. Internal rate of return sensitivity — gas/electric price changes. 


\section{Discussion}

\section{Picatinny Arsenal}

The NGEDAC system at Picatinny produces the required compressed air at lower cost than the pre-existing electric air compressor. Figure 47 shows the theoretical full-load production costs. At full load $(610 \mathrm{cfm})$, the NGEDAC system produces a cost savings of $\$ 22,000$ to $\$ 56,000$ per year assuming continuous operation and natural gas prices of $\$ 3.41-7.00 / 10^{6} \mathrm{Btu}$. At part load $(175 \mathrm{cfm})$, the NGEDAC system produces a cost savings of $\$ 18,000$ per year assuming continuous operation and natural gas prices of $\$ 3.41 / 10^{6}$ Btu and breaks even with the existing electric air compressor when natural gas reaches $\$ 6.50 / 10^{6} \mathrm{Btu}$. Furthermore, demand-side recommendations have helped reduce air requirements from $825 \mathrm{cfm}$ to $175 \mathrm{cfm}$.

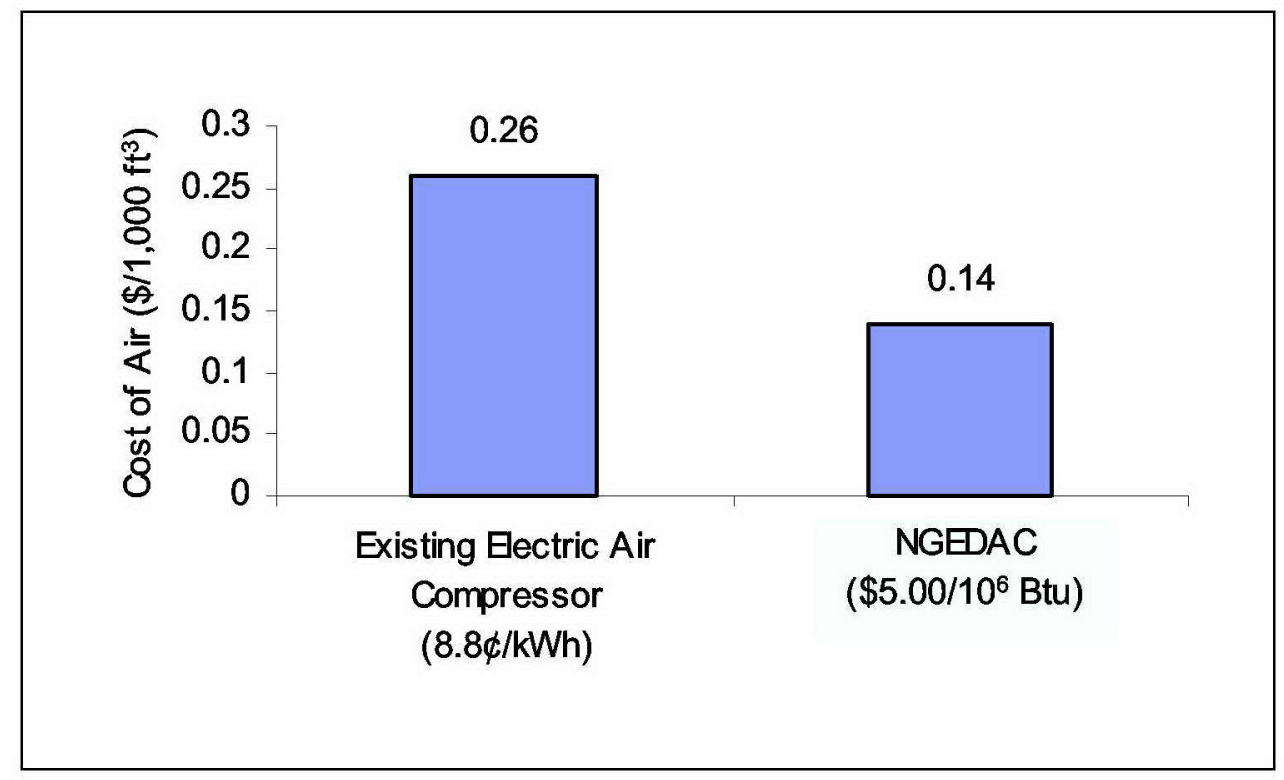

Figure 47. Theoretical full-load production costs for Picatinny. 


\section{Watervliet Arsenal}

The NGEDAC system at Watervliet produces the required compressed air at lower cost than the pre-existing electric air compressor. Figure 48 shows the theoretical full-load production costs. At full load $(1,480 \mathrm{cfm})$, the NGEDAC system produces a cost savings of $\$ 45,000$ to $\$ 127,000$ per year, assuming continuous operation and natural gas prices of $\$ 3.50-7.00 / 10^{6} \mathrm{Btu}$. At part load $(1,100$ cfm), the NGEDAC system produces a cost savings of $\$ 21,000$ to $\$ 89,000$ per year assuming continuous operation and natural gas prices of $\$ 3.50-7.00 / 10^{6}$ Btu. Furthermore, demand-side recommendations have helped reduce air requirements from $2,174 \mathrm{cfm}$ to $1,100 \mathrm{cfm}$.

The total project cost for the six site evaluations and two demonstrations was approximately $\$ 1,644,000$. The total annual savings for both sites ranges from a low of $\$ 268,000$ to a high of $\$ 357,000$. This equates to a simple payback of 4.5 to 6.0 years, which, for demonstration projects, is considered favorable.

\section{Sierra Army Depot}

The NGEDAC was installed for a price that was reasonably close to the estimate at the time of the conceptual design-about $\$ 222,135$ vs. $\$ 211,504$. The performance of the NGEDAC appears to be in-line with the manufacturer's estimate following some control/sensor modifications.

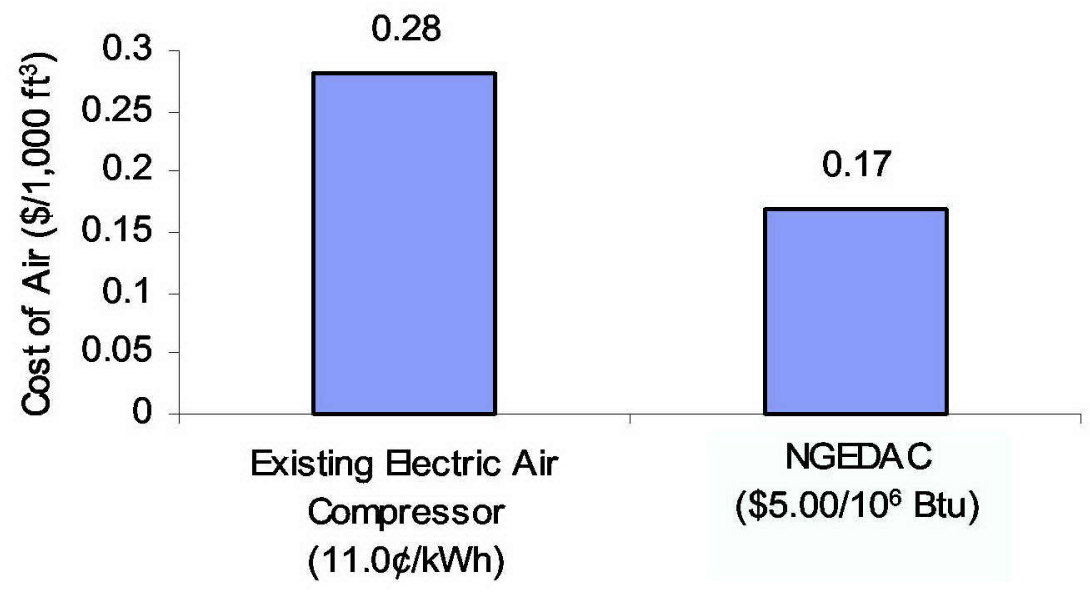

Figure 48. Theoretical full-load production costs for Watervliet. 
Table 39. Economics of the NGEDAC at SIAD.

\begin{tabular}{|c|c|c|c|}
\hline $\begin{array}{c}\text { Annual Energy Use and Peak } \\
\text { Demand }\end{array}$ & $\begin{array}{l}\text { Electric Air } \\
\text { Compressor }\end{array}$ & NGEDAC & Savings \\
\hline$x^{2}$ & $108.4 \mathrm{~kW}$ & $\begin{array}{c}1,456 \mathrm{kWh} \text { heat } \\
\text { recovery } \\
1021 \text { MBtu gas } \\
\text { engine } \\
(283) \text { MBtu heat } \\
\text { recovery } \\
1.07 \text { MBtuh }\end{array}$ & $\begin{array}{l}196,885 \text { kWh } \\
\text { (738) MBtu } \\
95 \text { kW -108 kW }\end{array}$ \\
\hline $\begin{array}{l}\text { Annual Operating and Maintenance } \\
\text { Costs }\end{array}$ & $\begin{array}{l}\text { Electric Air } \\
\text { Compressor }\end{array}$ & NGEDAC & Savings \\
\hline $\begin{array}{l}\text { Natural Gas } \\
\text { Electricity } \\
\text { Heat Recovery } \\
\text { Maintenance }\end{array}$ & $\begin{array}{r}\$ 0 \\
\$ 29,460 \\
\$ 0 \\
\$ 1,007\end{array}$ & $\begin{array}{r}\$ 3,150 \\
\$ 212 \\
(\$ 873) \\
\$ 1,983\end{array}$ & $\begin{array}{r}(\$ 3,150) \\
\$ 29,248 \\
\$ 873 \\
(\$ 976)\end{array}$ \\
\hline Total & $\overline{\$ 30,467}$ & $\$ \$ 4,472$ & $\$ \$ 25,995$ \\
\hline
\end{tabular}

The economic analysis of SIAD based on measured fuel use data and updated energy price information (natural gas costs of $\$ 3.09 / \mathrm{MBtu}$ and electricity costs averaging $\$ 0.149 / \mathrm{kWh}$ ) indicates the NGEDAC's net annual savings should be about $\$ 26,000$ (Table 39). This equates to a simple payback of about 8.5 years in a retrofit situation (no capital cost credit for displacing a comparable electric motor driven air compressor), and 5.9 years in a new or replacement scenario (e.g., with a $\$ 68,000$ credit for the installed cost of a new, $125 \mathrm{hp}$ electric air compressor). Over an estimated 20-year system life, the net present value savings of the NGEDAC, including the installed cost of the unit, is about $\$ 154,000$.

The NGEDAC heat recovery system, while providing significant savings in natural gas is not cost-effective at current natural gas prices, due to its substantial capital costs and seasonal operation. In particular, the cost of piping the heat to a remote make-up air unit, added to the overall heat recovery system costs. The estimated payback period is 25.4 years.

NGEDAC installations require some additional considerations as compared to electric motor driven air compressors, but generally do not require special skills. The experience with the SIAD NGEDAC indicated that few installation problems should arise, assuming detailed engineering drawings and specifications are available. Contractors with experience with compressed air systems, natural gas compressor stations, and cogeneration systems should be able to handle the work. SIAD should consider upgrading the building that houses the NGEDAC (repairing/replacing insulation, etc.) to better protect the equipment from weather related problems (e.g., freeze conditions). 


\section{Conclusions and Recommendations}

\section{Conclusions}

This project assessed the viability of applying NGEDAC technology at Army industrial facilities, and demonstrated the technology at three Army installations. This study concludes that NGEDAC has itself to be a viable technology for use in the Army industrial operations involved in this demonstration. The demonstration has also provided hands-on operating experience that formed the basis for developing guidelines for NGEDAC installation and operations.

The success of this demonstration project was due in large part to the experienced equipment and installation vendors and supportive base staffs at the three demonstration sites. Site selection and vendor selection were two critical factors from the beginning of the project; their importance increased as the project progressed. NGEDAC technology is not new, but its application is not generally widespread. There are enough issues unique to NGEDAC systems that having experienced equipment vendors and having dedicated base staff should be considered essential elements in achieving a successful NGEDAC application. The base staff, which worked through the numerous details that arose during NGEDAC system installation and start-up, was critical to project success.

\section{Recommendations}

It is recommended that both Picatinny and Watervliet Arsenals continue to manage and reduce their air requirements. The Watervliet site has the additional opportunity of incorporating the NGEDAC performance data directly into its overall energy management control system. By monitoring performance data, Watervliet will be able to both manage and improve system performance.

There are also several issues related to the gas supply area that should be noted. While energy price uncertainty has always been a factor in any energy technology application, this project demonstrated the range over which energy price fluctuations must be considered. In the case of Picatinny Arsenal, the price of gas increased by a factor of three and then retreated to close to original levels during the 18-month NGEDAC project period. With the deregulation of gas 
markets, careful consideration must be given to the specific issues associated with gas prices, supply commitments, supply pressure requirements, metering information, and metering equipment and costs.

Most of the sites surveyed had significant opportunities to reduce air requirements through demand-side management programs. Such programs should be completed before final design of the NGEDAC unit, to balance the revised air requirements of the facility with the output capacity and operational characteristics of the NGEDAC system. In other words, rather than use an estimate of the system demand assuming reductions in air requirements, the actual requirements should be measured after demand-side programs have been completed.

All military manufacturing facilities should explore the opportunity for reducing air requirements and improving their current compressed air systems. While the savings from the NGEDAC units were significant under current energy prices, the savings accruing to the facilities from reductions in air requirements were even greater. Most of these savings could be achieved with a few targeted demand-side projects defined by an experienced compressed air professional. In addition, the operating experience and performance of the three demonstrations should be logged and reviewed periodically to enhance the understanding of how best to use NGEDAC technology. Additional demonstration sites could be earmarked for NGEDAC systems, as long as they meet the threshold ratio of electric price to gas price, and the criteria of vendor experience and facility staff discussed previously.

The results of this project indicate the benefits of compressed air surveys in identifying opportunities to reduce compressed air operating cossts, and specific applications where NGEDACs make technical and economic sense. Recommendations to bring these benefits to military facilities include the following suggestions for Defense Installations

- Conduct a compressed air survey if one has not been performed. Air flow monitoring should be conducted to provide insights into system operation. Consider periodic follow-up surveys.

- Establish a compressed air system leak management program.

- Consider NGEDACs as an alternative to electric motor driven air compressors. Make sure the specifications include an accurate load profile. Actual compressor loads can be very different from estimates based on operator's assumptions about their process equipment's air requirements. Make sure to evaluate the part load performance of the options being considered.

- Perform ongoing or follow-up monitoring of the NGEDAC to obtain sufficient information on fuel use, maintenance, etc. over time. This will provide a 
more solid foundation on which to base projections of the NGEDAC's economic benefits.

- Maintenance should be tracked particularly closely, with a view towards isolating the cost differentials between NGEDACs and electric motor driven air compressors.

- Monitor all NGEDAC sites to better understand differences among different manufacturer's products, and to increase the overall confidence in the data collected.

- Follow-up with site surveys to see if they have implemented any of the survey recommendations, and if so estimate/document the benefits. 


\section{Appendix A: Demonstration at Sierra Army Depot, Request for Quotation (RFQ) for Compressors}

\section{Request for Quotation}

Science Applications International Corporation (SAIC) is requesting a quotation for two (2) packaged air compressors that are to be delivered and installed at the Sierra Army Depot (SIAD):

1. Natural Gas Engine-Driven Air Compressor (NGEDAC). The packaged natural gas engine-driven air compressor (NGEDAC) will consist of a single factory assembled and tested, skid mounted assembly of a natural gas engine, compressor, controls and auxiliary equipment that allow the compressor to operate as a standalone air compressor system. The packaged system will be designed to operate under a variable speed operating scenario to take advantage of the part load operating efficiency of the combined engine and compressor technologies. The system will be supplied with equipment to allow for heat recovery to a new hydronic loop and then air cooled for heat rejection to meet the packaged system cooling requirements. The unit will be self-contained such that the heat rejection equipment needed for operation of the NGEDAC will be powered by the engine rather than an outside power source. This will enable operation of the NGEDAC in the event of power disruptions. The NGEDAC must meet all local, state, and Federal environmental regulations.

3. Electric Motor-Driven Oil-free Air Compressor

The packaged electric motor-driven air compressor will consist of a single factory assembled and tested, skid mounted assembly of a 3-ph electric motor, oil-free air compressor, controls and auxiliary equipment that allow the compressor to operate as a standalone air compressor breathing air system. The system is to be aircooled and includes single stage compression to permit the delivery of oil-free air at reduced rotational speeds resulting in longer Mean Time Before Repair (MTBR) and reduced operational cost. The system controls include start/stop sequencing, load regulation, shutdown capability and display of internal system parameters. The system enclosure is to provide noise reduction and convenient heat rejection. 
These air compressors are to be installed under a Department of Defense demonstration project.

\section{Schedule}

The compressors shall be delivered to the Sierra Army Depot, Herlong, CA on or before 11 January 2002.

\section{Quote Format}

This quote is for one (1) packaged natural gas engine-driven air compressor system (NGEDAC) and one (1) electric motor-driven oil-free air compressor system. Note that we are requesting a quote for two different capacity NGEDAC units and will select one of the two units.

AC Package

NGEDAC (option 1)

NGEDAC (option 2)

Electric Motor-Driven Oil-Free Air Compressor

$$
\text { Flow Rate(SCFM) }
$$

375

115
Pressure(psig)

100

100

100

The SCFM condition assumes $14.7 \mathrm{psia}, 60^{\circ} \mathrm{F}$, and 0 percent RH. Please note for the purposes of equipment sizing and performance, that the installation site is at an elevation of $4,200 \mathrm{ft}$ above sea level assuming a temperature of $100^{\circ} \mathrm{F}$, and 60 percent Relative Humidity (RH).

Please provide a firm fixed price quote for each item. The quote shall contain the following information.

NGEDAC (option 1):

- Nominal Engine Size: HP at standard conditions

- Nominal Compressor Capacity: __ ACFM @ $\overline{100 \mathrm{psig}}$

- Nominal Compressor Capacity:__SCFM @ 100 psig

- Method of Emission Control (Low Emission Engine, Catalytic Converter, etc)

- Design Natural Gas Supply Requirement:___SCFH @___ w.c.

- Engine Cooling: Integrated into package or remote

- If remote, provide overall dimensions and size of pipe connections

- Compressor Cooling: Integrated into package or remote

- If remote, provide overall dimensions and size of pipe connections

- After Cooler: Integrated into Package or remote

- If remote, provide overall dimensions and size of pipe connections

- After cooler and Compressor Cooling Integrated into one system (Y/N)

- Overall package dimensions ( $\mathrm{L} \times \mathrm{W} \times \mathrm{H})(\mathrm{cu} \mathrm{ft})$

- Overall package weight

- Warranty Duration and Coverage

- Freight Cost (factory to Herlong, CA)

- Equipment Cost 


\section{NGEDAC (option 2):}

- Nominal Engine Size: HP at standard conditions and HP at site conditions

- Nominal Compressor Capacity:

- Nominal Compressor Capacity: ACFM@100 psig

Method of Emission Control (Low Emission Engine, Catalytic Converter, etc)

- Design Natural Gas Supply Requirement: SCFH@, "w.c.

- Engine Cooling: Integrated into package or remote

- If remote, provide overall dimensions and size of pipe connections

- Compressor Cooling: Integrated into package or remote

- If remote, provide overall dimensions and size of pipe connections

- After Cooler: Integrated into Package or remote

- If remote, provide overall dimensions and size of pipe connections

- After cooler and Compressor Cooling Integrated into one system $(\mathrm{Y} / \mathrm{N})$

- Overall package dimensions $(\mathrm{L} \times \mathrm{W} \times \mathrm{H})(\mathrm{cu} \mathrm{ft})$

- Overall package weight

- Warranty Duration and Coverage

- Freight Cost (factory to Herlong, CA)

- Equipment Cost

Electric Motor-Driven Oil-Free Air Compressor:

- Nominal Motor Size (KW)

- Nominal Compressor Capacity:

- Nominal Compressor Capacity: ACFM@100 psig

Compressor Cooling. Integrated into package or remote

- If remote, provide overall dimensions and size of pipe connections

- Overall package dimensions $(\mathrm{L} \times \mathrm{W} \times \mathrm{H})(\mathrm{cu} \mathrm{ft})$

- Overall package weight

- Warranty Duration and Coverage

- Freight Cost (factory to Herlong, CA)

- Equipment Cost

Packaged NGEDAC Performance (Option 1)

Parameter

Supply Air Flow (ACFM)

Supply Air Flow (SCFM)

Supply Air Pressure (psig)

Compressor Brake Horse Power (bhp)

Fuel Consumption (Million Btu/Hour)

(State basis: HHV or LHV)

Fuel Consumption (SCFH)

Emissions: NOx (lbs/hour)

Emissions: CO (lbs/hour)

Emissions: NMHC (lbs/hour)

Packaged NGEDAC Performance (Option 2)

Parameter

Percent of Full Load Operation $100 \% \quad 75 \% \quad 50 \% \quad 25 \%$

Supply Air Flow (ACFM)

Supply Air Flow (SCFM)

Supply Air Pressure (psig)

Compressor Brake Horse Power (bhp)

Fuel Consumption (Million Btu/Hour)

(State basis: HHV or LHV)

Percent of Full Load Operation $100 \% \quad 75 \% \quad 50 \% \quad 25 \%$ 
Fuel Consumption (SCFH)

Emissions: NOx (lbs/hour)

Emissions: CO (lbs/hour)

Emissions: NMHC (lbs/hour)

Packaged Oil-Free Electric-Driven Performance

Parameter

Percent of Full Load Operation $100 \% \quad 75 \% \quad 50 \% \quad 25 \%$

Supply Air Flow (ACFM)

Supply Air Flow (SCFM)

Supply Air Pressure (psig)

Compressor Brake Horse Power (bhp)

Power Consumption (kW)

Electric Auxiliary Loads (kW)

Notes: SCFH: Standard cu ft per Hour

HHV: Higher Heating Value

LHV: LOWER HEATING VALUE

NMHC: Non-Methane Hydrocarbons

SCFM: Standard cu ft Per Minute

ACFM: Actual cu ft Per Minute

Accessories (NGEDAC only)

1. Heat Recovery System

Details of the site process load are presented in the attached specification. It is the intent of this request, for the equipment supplier to propose the most cost effective heat recovery option based on the available heat from the compressor package and the thermal load for the site. Provide a description of the proposed heat recovery equipment to be provided along with a schematic of the interface to the air compressor package and the site hydronic loop (series or parallel piping). For the purposes of equipment sizing assume that the heat transfer fluid on the process-side (site load) is water. For each heat recovery system, provide the following:

- Engine Jacket Water Heat Exchanger

* Design heat transfer rate (BTU/Hour)

* Process-side: Flow Rate (gpm)

* Process-side: Entering Water Temperature

* Process-side: Leaving Water Temperature

* Dimensions ( $\mathrm{L} \times \mathrm{W} \times \mathrm{H})(\mathrm{cu} \mathrm{ft})$

* Size, type and quantity of pipe connections

* Equipment Cost

- Compressor Oil Heat Exchanger

* Design heat transfer rate (BTU/Hour)

* Process-side: Flow Rate (gpm)

* Process-side: Entering Water Temperature

* Process-side: Leaving Water Temperature

* Dimensions ( $\mathrm{L} \mathrm{x} \mathrm{W} \mathrm{x} \mathrm{H)} \mathrm{(cu} \mathrm{ft)}$

* Size, type and quantity of pipe connections

* Equipment Cost

Maintenance (NGEDAC only)

Provide a quotation for a two (2) year maintenance contract assuming annual operation of 2,100 hours. The contract shall cover routine preventative maintenance of the engine and compressor. 
Two year routine preventative maintenance for the compressor package for up to 4,200 hours of operation (Option 1): $\$$

To evaluate life cycle costs; please provide annual maintenance costs up to and including the first major overhaul.

NGEDAC (Option 1)

Year \# of Hours of Operation Engine Cost (\$) Compressor Cost (\$) Total Cost (\$)

12,100

24,200

$3 \quad 6,300$

48,400

$5 \quad 10,500$

6

7

Two year routine preventative maintenance for the compressor package for up to 4,200 hours of operation (Option 2): \$

NGEDAC (Option 2)

Year \# of Hours of Operation Engine Cost (\$) Compressor Cost (\$) Total Cost (\$)

12,100

$2 \quad 4,200$

$3 \quad 6,300$

48,400

$5 \quad 10,500$

6

7

Selection Criteria

The goal of the program is to demonstrate the advantages of the natural gas engine-driven air compressor technology as compared to conventional electric air compressor technologies. As a demonstration of the cost effectiveness of the engine-driven air compressor technology, the most important factors in equipment selection are provided in the following table.

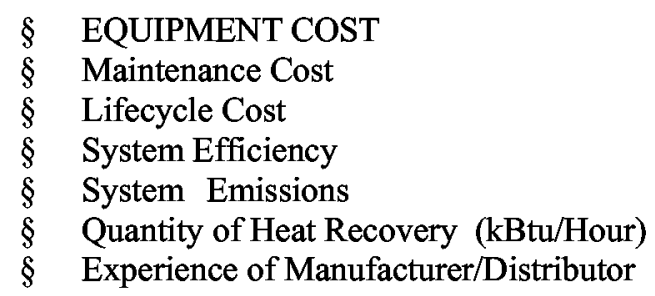

References

Provide a list of representative compressor systems sold over the past 5 years. Provide at least three references that may be contacted.

Responses

Responses and questions should by addressed to

SAIC

Associate Buyer

Phone (301)353-1880

Fax (301)353-1887

(Responses shall be submitted by 17 October at 4:00 pm.) 


\section{Appendix B: Request for Quotation (RFQ) for Installation Contractor}

Date:

$<$ Prospective Subcontractor Name: $>$

<Address:>

Attention:

Subject: Request For Quotation (RFQ)

References:

(A) Program Name: Sierra Army Depot - Compressor Installation

(B) Statement of Work (SOW)

(C) Basis of Design (BOD)

(D) Design Package

Gentlemen:

You are requested to submit a firm fixed price quotation for the installation of pre-purchased air compressors. We request that the quotation be submitted to include the three installation options:

1) Installation of Ingersoll-Rand/Gascom 139 HP Natural Gas Engine-

Driven Air Compressor Only

2) Installation of Gardner Denver 40 HP Electric Oil-free Air Compressor Only

3) Installation of Both Compressors Concurrently

The Statement of Work including the schedule and acceptance criteria are included in Attachment 1 (reference "B"). Quotations shall present detailed costs per installation sub-component (combined materials and labor) as

indicated in the table below:

\begin{tabular}{|c|c|c|c|c|}
\hline Item & Sub-Component & $\begin{array}{c}\text { Engine- } \\
\text { Driven Air } \\
\text { Compressor } \\
\text { Quote }\end{array}$ & $\begin{array}{c}\text { Electric Oil-Free } \\
\text { Air Compressor } \\
\text { Quote }\end{array}$ & $\begin{array}{c}\text { Both } \\
\text { Compressors } \\
\text { Quote }\end{array}$ \\
\hline 1 & Structural & $\$$ & $\$$ & $\mathbf{S}$ \\
\hline 2 & Electrical & $\$$ & $\$$ & $\$$ \\
\hline 3 & $\begin{array}{l}\text { Mechanical \& } \\
\text { Plumbing }\end{array}$ & $\$$ & $\$$ & $\$$ \\
\hline 4 & Controls & $\$$ & $\$$ & $\$$ \\
\hline 5 & Heat Recovery & $\$$ & Not $A$ pplicable & $\$$ \\
\hline 6 & Architectural & $\$$ & $\$$ & s \\
\hline 7 & Specific Equipment & $\begin{array}{c}\text { Not } \\
\text { Applicable } \\
\text { (Existing } \\
\text { Receiver and } \\
\text { Dryer Used) }\end{array}$ & $\begin{array}{l}\text { 1) Receiver } \\
\text { 2) Dryer } \\
\$\end{array}$ & $\begin{array}{l}\text { 1) Receiver } \\
\$ \\
\text { 2) Dryer } \\
\$\end{array}$ \\
\hline 8 & Total Cost & $\$$ & $\$$ & $\$$ \\
\hline
\end{tabular}




\section{SPECIAL QUOTATION INSTRUCTIONS AND INFORMATION}

\section{Type of Agreement: Firm Fixed-Price}

a. Installation Completion Date: 30 January 2002.

b. Terms and Conditions: Any agreement resulting from this solicitation shall resemble the sample agreement, inclusive of other attachments enclosed and include all clauses required by law on the date of execution. The terms and conditions set forth or referenced herein by SAIC shall apply and SAIC objects to and shall not be bound by any additional or different terms and conditions proposed by the Offeror. Your quotation shall be inclusive of all costs associated with performing the work in accordance with the attached terms and conditions. Please do not fill out the enclosed Sample Agreement when submitting your quotation. Should your firm receive an award as a result of this RFP, SAIC will issue the completed agreement for your execution.

2. Quotation Due Date: Please submit your quotation as soon as possible but no later than close of business, on Thursday, 3 January 2002. Your quotation should be faxed to the attention of SAIC at (301) 353-1887.

\section{Cost/Price Submittal Requirements:}

a. Insurance Coverage: SAIC calls your attention to the enclosed Sample Subcontract Agreement, specifically the requirements of Clause 6.0, Insurance and 6.1, Coverage. Please ensure that the Insurance Certificate(s) you submit with your quotation are compliant with the provisions of these clauses including the requirement for Professional Liability Insurance shown in clause 6.1.

4. Quotation Contents: Items to be included with your quotation:

a. Firm Fixed-Price for the type(s) of installations requested herein.

b. Vendor Master Data Template

c. Certificate(s) of Insurance

d. Government Property Questionnaire

e. Annual SAIC Certifications and Representations

f. Certifications and Representations, Part D

5. Quotation Submission: You are requested to submit an original and (1) copy of your quotation to the following address:

\section{SCIENCE APPLICATIONS INTERNATIONAL CORPORATION 20201 Century Blvd., 3rd Floor \\ Germantown, MD 20874}

6. Quotation Validity: To be considered valid, your quotation must be addressed to the undersigned and remain firm for ninety (90) days from quotation due date.

7. Questions Regarding This Solicitation: Questions should be addressed to the following individuals:
Technical
Contractual
Mr. Robert Lorand
Martin T. Lydard
Ph. (703) 676-4439
Ph. (301) 353-1875
Fax:(703) 356-4056
Fax:(301) 353-1887

Please be advised that this RFP does not commit SAIC to pay any cost associated with preparation and submission of a quotation and that the SAIC Contractual Representative is the only individual 
authorized to legally commit SAIC to the expenditure of funds related to this solicitation. This is not an authorization to proceed with work.

BY ACKNOWLEDGEMENT OF YOUR RESPONSE TO THIS SOLICITATION, THE OFFEROR HEREBY CERTIFIES THAT NO GRATUITIES WERE OFFERED BY THE OFFEROR OR SOLICITED BY ANY SAIC EMPLOYEE EITHER DIRECTLY OR INDIRECTLY. ANY SITUATION WHERE A GRATUITY IS SOLICITED SHOULD BE REPORTED IMMEDIATELY TO THE VICE PRESIDENT AND DIRECTOR OF PROCUREMENT AT (858) 826-7642.

Should you have any questions regarding this RFQ, please contact the undersigned at (301) 353-1875.

Sincerely,

SCIENCE APPLICATIONS INTERNATIONAL CORPORATION

Martin T. Lydard

Senior Subcontracts Representative

Attachments:

(1) Statement of Work

(2) Basis of Design

(3) Design Package

(4) RFQ General Provisions

(5) Annual Certs and Reps

(6) Certs Part D

(7) Government Property Questionnaire

(8) Vendor Master Template

(9) Sample Fixed Price Subcontract Agreement

(10) Schedule B, U. S. Government Terms/Conditions, Part 1 FAR Clauses

\section{ATTACHMENT 1: STATEMENT OF WORK (SOW)}

Sierra Army Depot

Installation of Natural Gas Engine-Driven Air Compressor

\subsection{INTRODUCTION}

Science Applications International Corporation (SAIC) is under contract to the U.S. Army Construction Engineering Research Laboratory (CERL) to install a natural gas engine-driven air compressor (NGEDAC) at the Sierra Army Depot (SIAD) in Herlong, California. SIAD is located approximately 50 miles north of Reno, Nevada on highway 395.

The objective of the project is to demonstrate the NGEDAC technology for Department of Defense (DOD) facilities. SAIC has developed a detailed engineering design for the installation of the NGEDAC (via Walsh Engineers). A heat recovery system will be included with the NGEDAC to provide pre-heating for the Make-up Air unit (MAU-1) for space heating during the winter months. The NGEDAC unit will replace the existing electric motor-driven air compressor as the primary compressor. After NGEDAC installation, the existing electric motor-driven air compressor will serve as a backup unit. In addition, an electric motor-driven oil-free air compressor will be installed for the paint and sand blasting booth's breathing air system (optional quotation).

1.1 Technical Scope of Services 
The requested scope of services is the installation of the NGEDAC and the oil-free air compressor (optional), including the necessary facility modifications.

The installation scope for the NGEDAC includes:

1) Structural

1.1) Equipment pad improvement

1.2) Compressor room improvement (doors and intake and exhaust)

2) Electrical

2.1) 110VAC service to NGEDAC (internal lighting)

2.2) 220VAC service to Heat Recovery circulation pump

2.3) 220VAC service to Sump Pump

2.4) Control System

3) Mechanical and Plumbing

3.1) Natural gas service to NGEDAC

3.2) Compressed process-air piping

3.3) Heat recovery hydronic piping to make-up air unit (MAU)

3.4) Drainage piping to sump

3.5) Inlet and exhaust air ducting to NGEDAC

4) Equipment Installation

4.1) NGEDAC

4.2) Heat recovery Circulation pump + Air Separator

4.3) MAU pre-heating coil

4.4) Expansion Tank

4.5) Sump pump

The installation scope for the optional Oil-free Air Compressor includes:

1) STRUCTURAL

1.1) Equipment pad improvement

1.2) Compressor room improvement

2) Electrical

2.1) 460VAC service to Oil-free Compressor

3) Mechanical \& Plumbing

3.1) Compressed breathing-air piping

3.2) Inlet air ducting

3.3) Makeup water service

3.4) Drainage piping to sump

4) Equipment Installation

4.1) Oil-free Air Compressor

4.2) Receiver Tank

4.3) Dryer

The installation contractor will also support and participate in the Acceptance Test of all installed design upgrades. For the purposes of this program, an upgrade is defined as the addition of major equipment and critical sub fixtures such as valves, supporting fixtures, fasteners, etc.; repairs of foundations and enclosures.

\subsection{Objective}

The task objective is the successful installation of the Gascom Natural Gas Engine-Driven Air Compressor (NGEDAC) and the heat recovery system per the design package (Walsh Engineers). The optional objective is the installation of the Gardner Denver oil-free air compressor system per the design package (Walsh Engineers). Acceptance Testing will be conducted by SAIC and the NGEDAC equipment vendor with the support of the installation contractor. 
The following documents form a part of this SOW to the extent specified herein. Unless otherwise specified, the latest edition of these documents shall be used for the purpose of this SOW. In the event of conflict between the documents referenced herein and the contents of this SOW, the contents of this SOW shall supersede.

\subsection{Specifications}

- Design package, "Install Natural Gas Engine-Driven Air Compressor System", dated 20 Nov 2001.

Sheet Title

T-1 Title Sheet

G-1 General Arrangement

M-1 Equipment Placement \& Piping Routing Plan

M-2Installation Plan

M-3Elevations \& Sections

M-4Details

M-5Natural Gas \& Hydronic Piping

M-6Gas Supply Modifications

M-7Hydronic Coil Installation

M-8Installation Schematics - NGEDAC

M-9Air Intake System

M-10 Fire Protection System

M-11 P\&ID - Compressed Air System

M-12 Control System

M-13 Schedules/Specifications

E-1 Electrical Installation Plan

E-2 Electrical

S-1 Structural

A-1 Architectural Plan

A-2 Architectural Details \& Specifications

- Document, "Basis of Design", dated 30 Nov 2001.

\subsection{TASK REQUIREMENTS}

Milestones have been identified upon completion of task increments of the NGEDAC installation. These are shown below:

Milestone

Site Preparation

Installation
Task Increment

1) Permitting

2) Equipment Pad Improvement

3) Compressor Room Improvement

4) Natural Gas Line Piping

5) Compressed Air Piping

6) Inlet Air \& Exhaust Ducting

7) Heat Recovery Piping

8) Electrical Wiring

9) Drainage Piping

1) Compressor/Engine Package Install

2) Inlet Air/Exhaust Interface

3) Heat Recovery Interface 


\section{4) Control Interface}

$\mathrm{T} \& \mathrm{C}$

1) Acceptance Testing

\subsection{Installation}

Using the design package and Basis of Design listed in 2.1, an Installation Plan (IP) will be submitted as part of the installation contractor's proposal to SAIC. The IP will show all project activity including any special needs (permits, work orders, etc.) required from SAIC to complete the project, including a schedule for the activities. The format of the IP may be the installation contractor's choice.

After approval of the Installation Plan, installation activities will commence. The installation contractor will be responsible for any disassembly and removal of equipment. SAIC will provide disposition instruction for any removed equipment or hardware and identify where it is to be stored or located.

SAIC will coordinate onsite installation activities with SIAD personnel and resolve conflicts in equipment availability or usage, power interrupts, etc. SAIC will monitor the progress of the installation process and its adherence to the installation contractor's installation planning documents.

The installation contractor will take action to obtain work permits, SIAD passes, movement of materials and equipment to and from the job site and comply with all SIAD security and safety requirements during the installation process. As required, SAIC will assist in the preparing the documentation needed to obtain base passes.

\subsection{Acceptance Testing}

The installation contractor shall assist in determining the functionality of the equipment/subsystems (e.g., integrity of piping, ductwork, electrical, etc.) This will include participation with SAIC, the equipment vendor, the engineering design firm, and SIAD representatives to review the test requirements, related support facility needs and the test schedule. Functional testing will be conducted by the installation contractor at the facility and witnessed by SAIC, CERL and its representatives. Records of all testing vs. pass/fail criteria will be provided by the installation contractor to SAIC within 3 working days after the completion of the system testing. Successful completion of the functional testing will constitute completion of the installation contractor's work. This will include participation with SAIC, the equipment vendor, the engineering design firm, and SIAD representatives to review the test requirements, related support facility needs and the test schedule.

\subsection{DELIVERABLES}

Deliverable equipment will be identified to SAIC per Section 3. Completion of deliveries is identified as the successful passing of the Functional Test Reports.

Additional data requirements to be supplied by the installation contractor is listed in the following table:

Data Requirement Equipment Installation Plan (IP) Functional Test Report
Format

Electronic \& Hard Copy

Hard Copy
Quantity/Frequency

1 Draft, 1 Final

Completion of each

major subsystem test 
The Table below is the preliminary Master Schedule for the installation of the NGEDAC system. The activity tasks listed follow the milestone and task increments described in section 3.0. The installation contractor will develop schedules as required and assign the appropriate staff to ensure that the stated objectives are met. The two compressors are currently scheduled to be delivered to the job site by 21 January 2002. The installation to be completed no later than January 30, 2002. Note that deviations from this schedule will not be allowed, without prior approval by SAIC. The installation contractor shall be prepared to set the compressors on the new equipment pads when they are delivered. SIAD has the requisite forklifts and has indicated that they will support unloading of major equipment if the activities are coordinated and sufficient notice is provided.

\begin{tabular}{|c|c|c|c|c|c|c|c|c|c|c|c|}
\hline 10 & Task Nanne & Dutration & Start & Finish & Octaber & Woventher & December & JanLary & Fetruary & Warch & April \\
\hline 1 & Award Installation Contractor & 13 days & MOC Nov 19, '01 & Fridec 7, "01 & & & & & & & \\
\hline 2 & Site Frep - Equipment Pad & 15 days & Mon Dec 17, 01 & Thu Jan 10, 02 & & & & & & & \\
\hline 3 & Site Prep - Comp. Rin. Inprove & 15 days & Mon Dec 17, ${ }^{\prime} 01$ & Thu $\operatorname{Jan} 10,102$ & & & & & & & \\
\hline 4 & Site Prep - Nat. Gas Line Piping & 15 days & Mon Dec 17, '01 & Thu dan 10,102 & & & & & & & \\
\hline 5 & Site Frep - Compressed Air Piping & 15 days & Won Dec 17, ${ }^{\prime} 01$ & Thu Jan 10, 102 & & & & & & & \\
\hline 6 & Site Prep - Inlet: $E x h$. Ducting & 15 days & Mon Dec 17, 01 & Thu Jan 10,102 & & & & & & & \\
\hline 7 & Site Prep - Heat Roy'y Piping & 15 days & Mon Dee $17,{ }^{\prime} 01$ & Thu Jan 10,102 & & & & & & & \\
\hline 8 & Site Frep -Electrical Wiring & 15 days & Mon Dec 17, '01 & Thu Jan 10, 102 & & & & & & & \\
\hline 9 & Site Prep - Drainage Piping & 15 days & Mon Dec $17,{ }^{\prime} 01$ & Thu Jan 10, '02 & & & & & & & \\
\hline 10 & Instal - Compressor Install & 8 days & Wed $\tan 2,{ }^{102}$ & Fri Jan 11, '02 & & & & & & & \\
\hline 11 & Instal - Comp/Engine IF & 8 days & Mon Jan 14, '02 & Whed Jan 23 , '02 & & & & & & & \\
\hline 12 & Instal - Inlet.Exh. I.F & 8 days & Mon Jan 14, ${ }^{0} 02$ & Wied Jan 23, 02 & & & & & & & \\
\hline 13 & Instal - Heat Ricy y I.F & 8 days & Mon Jan 14, 02 & Wied Jan 23 , '02 & & & & & & & \\
\hline 14 & Instal - Control IIF & 8 days & Mon Jan 14,102 & 'Wed Jan 23, '02 & & & & & & & \\
\hline 15 & TRC-Testing & 5 days & Thu Jan $24,{ }^{\prime} 02$ & Whed Jan 30, '02 & & & & & & & \\
\hline 15 & T\&C - Acceptance & 2 days & Thu Jan $31,{ }^{\prime} 02$ & Fri Feb 1, '02 & & & & & & & \\
\hline
\end{tabular}

\subsection{INSTALLATION CONTRACTOR FURNISHED EQUIPMENT (CFE)}

The installation contractor will provide all tools and equipment required for facility modification and for the installation of new equipment including ancillary connecting, controlling or sub-functional equipment for the NGEDAC system.

Delivery vehicles are permitted to deliver only project specific equipment to the base. Nonproject specific equipment must be off loaded at the front gate. Note that there is no unloading equipment (i.e. forklifts, cranes, loading docks, etc.) at the front gate. All deliveries must be sent to the attention of:

Contact: Lead Maintenance Supervisor

Organization: $\quad$ Sierra Army Depot, Herlong, CA

\subsection{COMMUNICATIONS AND ACCESS TO SIAD}

SAIC will be actively engaged in onsite supervision and will work closely with the installation contractor. Communications by e-mail or facsimile can also be used to communicate any technical issues. However, any changes to cost, schedule or scope resulting from these discussions must be made formally through SAIC's contract process.

Base hours of operation are from 7:00am to 5:00 p.m. Monday through Thursday. All deliveries shall be coordinated with the base. These items will be considered as Government-owned and will be protected as such using the installation contractor's preferred procedures. An inventory of all delivered equipment shall be kept and supplied to SAIC at the completion of the contract.

\subsection{ACCEPTANCE}

Reports, data and deliverables shall be submitted to the SAIC Project Team member for inspection and acceptance. Acceptance of data will be provided within 24 hours after receipt of reports, data and deliverables. 


\section{SECURITY}

All installation contractor personnel must get badge every day to gain access to the base (valid driver's license is adequate identification for base permit). Non-job-specific equipment is not permitted on the base. Any such equipment brought to the base must be deposited at the front gate. Use of Foreign nationals will be permitted to gain access to the base, but must be escorted at all times; failure to do so my result in termination of the contract.

\section{PERIOD OF PERFORMANCE}

The completion date for all activities identified in this Statement of Work is 1 February 2002.

\section{PROJECT TEAM MEMBERS}

\section{NGEDAC Project Manager}

Bob Lorand

Tel: (703) 676-4439

Fax:(703) 356-4056

Email: robert.t.lorand@saic.com

Program Manager

John Westerman

Tel: (858) 826-9116

Fax:(858) 826-9126

Email: westermanj@saic.com

Project Engineer Don Carlson

Tel: (858) 826-9473

Fax:(858) 826-9126

Email: carlsondon@saic.com

\section{ATTACHMENT 2: BASIS OF DESIGN (BOD)}

Sierra Army Depot

Natural Gas Engine-Driven Air Compressor

Summary of Work Scope

- Natural Gas Engine Driven Air Compressor

- Oil-less Electric Motor Driven Air Compressor

- Heating Hot Water Waste Heat Recovery System

- Natural Gas System

- Compressor Intake Air System

- Sanitary Waste System

- Fire Protection System

- Miscellaneous Tasks

- $\quad$ Piped Utilities and Accessories

- Controls

- Commissioning

- Architectural

- Structural

- Electrical

- Excluded Items 


\section{Natural Gas Engine Driven Air Compressor (NGEDAC)}

Compressor/engine package has been pre-purchased including ancillaries consisting of:

- compressor intake air filter

- engine intake air filter

- exhaust muffler/catalytic converter

- $10 \mathrm{ft}$ of 3-in. O.D. stainless steel tubing

- 3 -in. bellows flex connector

- flanged base frame. Unit mountings will be drilled and set with engine/compressor package in place.

- acoustic enclosure that also serves as a cooling air passage way, with air inlet and outlet on opposing ends.

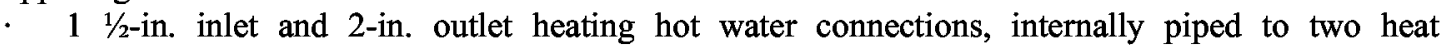
exchangers, one to recover heat from engine cooling water and one to recover heat from compressor oil cooler.

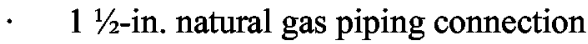

- 2 -in. compressed air piping connection

- On board control panel

Unit cooling exhaust air will be removed via an exhaust duct routed to an exterior wall mounted louver. Air will be recirculated back into the room as required to maintain a minimum room temperature of $50^{\circ} \mathrm{F}$ via interacting opposed blade dampers with actuators in the exhaust duct and thermostatic controls.

Engine exhaust shall be piped up through roof to combined muffler/catalytic converter via 3-in. O.D. stainless steel tubing. Piping shall terminate with a flapper type hinged cover. Provide thermal blanket around silencer to ensure heat protection of roof.

Muffler shall be mounted externally to roof via $1 \frac{1}{2}$-in. angle steel bracing and banding, welded to existing roof frame and weatherproofed for water tightness.

A gas shutoff valve shall be provided at package inlet connection with control interlocked with control panel provided with unit.

Provision for future measurement and verification shall be provided via a 3/4-in. thermowell or tap, isolated female $1 / 2$-in. NPT fitting, and spool piece for a temporary air flow meter in the discharge air piping.

\section{Oil-less Motor Driven Air Compressor}

Compressor/motor package has been pre-purchased including ancillaries consisting of:

- 4-in. intake air connection

- flanged base frame. Unit mountings will be drilled and set with compressor/motor package in place.

- acoustic enclosure that also serves as a cooling air passage way, with air inlet and outlet on top of package.

- 2-in. discharge air connection

- 1 -in. industrial cold water connection

- 1-in. water drain connection

- On board control panel

Unit cooling exhaust air will removed via an exhaust duct routed up through the roof and terminated with a $90^{\circ}$ elbow and $1 / 2$-in. mesh screen over opening.

Receiver shall be 500 gal @ 165 psig, vertical cylinder with support legs, primed finish, threaded NPT piping connection for drain, and flanged piping connections for air. 
Air dryer shall be Gardner-Denver Model, capable of $150 \mathrm{scfm}$ at $165 \mathrm{psig}$, air quality of $39^{\circ} \mathrm{F}$ wet bulb or approved equal.

All filters shall match existing.

Heating Hot Water Waste Heat Recovery System

Retrofit existing make-up air unit (MAU-1) with a $100 \times 42$-in. aluminum/copper two row coil by separating air handler at joint between filter and furnace sections and inserting coil. Mount coil to unit using existing internal 2 -in. flanges and "sandwiching" coil through use of existing bolt mounts.

Heating hot water pump shall be vertical in-line with TEFC motor.

Air separator shall be supplied with internal strainer.

Expansion tank shall hang above new inlet air louver via trapeze hanger suspended from roof frame above.

Provision for future measurement and verification shall be provided via a thermowell in the hot water outlet from the compressor, a thermowell in the hot water inlet to the compressor, and a spool piece for a water flow meter.

\section{Natural Gas System}

Retrofit existing manifold and replace existing regulator components per plans.

Provide and install a temperature and pressure compensated natural gas flow meter with a visual counter and a pulse signal output.

Extend regulator vents at least $10 \mathrm{ft}, 0$-in. above grade and MAU-1 intake opening.

Compressed Air Intake System

See plans for size and routing.

Sanitary Sewer Systems

Funnel drains shall be Smith 3520-F12 Funnel-ceptor Indirect Waste Drain with shallow trap / side outlet and adjustable strainer head.

All piping shall be sloped at $2 \%$.

Fire Protection System

Relocate existing branch water lines as required to allow installation of new equipment and materials.

Controls and interlocks TBD

Miscellaneous

New compressor room shall be heated through use of existing steam heated forced air heater. Heater shall be inspected and repaired as required. Replace existing wall mounted thermostat if required. Reconnect steam supply piping and recommission steam and condensate return piping. 
Relocate existing fire alarm pull down and fire alarm visual/audio alarm to new exit door near existing steam heater.

New reverse backflow preventer shall be wall mounted via unistrut and pipe clamps, with drain to funnel drain in existing compressor room.

Piped Utilities and Accessories

Sanitary sewer, waste and vent piping, above and below grade, shall be Schedule 40 cast iron no-hub pipe and fittings.

Industrial cold water, Type "L" copper, 95-5 lead-free solder joints.

Compressed air discharge piping, Type L copper cleaned and capped, silver brazed joints under nitrogen purge.

Compressor air intake piping, Schedule 40 PVC, with glue joints. Piping exposed to weather shall be painted for UV protection.

Heating hot water, Type "L" copper, 95-5 lead-free solder joints, insulated with 1/1/2-in. rigid insulation and vapor barrier.

Natural gas piping, ASTM A53 black steel pipe and fittings, 2-in. or smaller shall be threaded, $2 \frac{1}{2}-$-in. or larger shall be welded.

Steam and condensate drain piping shall match existing.

Drains, Type "M" copper and fittings with $95 / 5$ solder joints.

Trapeze hangers shall be 1-5/8-in. unistrut with $1 / 2$-in. threaded rod, secured to adequate structural members via clamps or welding of unistrut. Use clevis type hangers for individual pipe or where trapeze hangers are not practical.

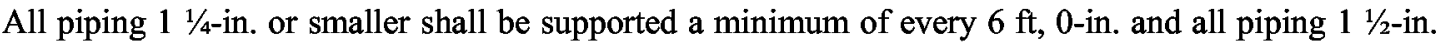
and larger shall be supported a minimum of every $10 \mathrm{ft}, 0$-in.

All valves shall be located within readily accessible areas.

Valve tags shall be provided for all valves and shall indicate service.

Piping Identification : All piping above grade shall be labeled with appropriate service along with directional flow arrows at a minimum of $20 \mathrm{ft}, 0$-in. intervals (minimum $10 \mathrm{ft}, 0$-in. intervals within new and existing compressor rooms).

\section{Controls}

Provide allowance for the following:

- Programming of existing compressor to start upon failure of NGEDAC failure.

- Interlock of HHW pump with MAU-1 controller and NGEDAC shutoff control.

- Interlock of fire alarm signal with NGEDAC gas shutoff valve and unit internal controls.

The NGEDAC package uses a radiator thermostat to control engine and compressor temperatures, hence, the heating hot water system will run continuously at maximum flow rate while the NGEDAC is operating. The existing "summer/off/winter" controller will be used to activate the existing gas furnace whenever the new hot water coil can not meet space heating loads. 


\section{Commissioning/Acceptance Testing}

The contractor shall participate in the commissioning/acceptance test of the NGEDAC and oil-less air compressors to confirm functionality of the equipment per the design specifications. This will also involve representatives of the NGEDAC and oil-less air compressors, facilities representatives, and SAIC representatives. The commissioning/acceptance testing will involve measurement and reporting on the following:

- NGEDAC package operating conditions and flows

- Oil-less compressor operating conditions and flows

- New air dryer operating conditions.

- Revamped steam powered room heater operating conditions.

- Make up air unit operating conditions and air flows

The installation contractor will be responsible for the integrity of the installation (piping, ductwork, electrical, concrete pad, etc.). The installation warranty shall be for (1) year from the date of facility acceptance including parts and labor.

Architectural

Provide new "barn" type doors for room entrance to fit existing beam frame opening. Doors to be provided with latch handle and locking mechanism. Provide rain dam to eliminate water intake below door. Paint doors to match building exterior.

Provide metal framing for louver installation. Framing should provide for watertight installation of louvers.

Provide new standard $3 \mathrm{ft}, 0$-in. x $6 \mathrm{ft}$, 8-in. exit door

Structural

Each of the two compressor bases (pads) shall be poured in placed reinforced concrete roughly 12-in. deep and 8-in. wider than each compressor footprint. This will require removal of portions of the existing slab area, to provide space for the new bases. Specifications for this work are forthcoming.

Electrical

See plans for size and routing.

Excluded Items

Refurbishment of roof to weatherproof standard.

Refurbishment of new compressor room interior walls.

Repair of existing lighting and electrical systems.

Measurement and verification of compressors' performance and related energy savings.

Relocation of existing Hazmat trailers to allow for improved exhaust air flow from NGEDAC. 


\section{Appendix C: Maintenance Contracts for NGEDAC at SIAD}

Two years of routine preventative maintenance based on 2100 operating hours per year shall be provided with the bid. The maintenance is to be performed by Cisco Air Systems, Inc. staff or Gascom staff depending on the specific maintenance actions. The contract start date is 4/11/02 and the end date is 4/10/04. The maintenance actions and schedule are provided below:

\section{GASCOM SERVICE PLAN}

Service Plan\#: SP052302A Sierra Army Depot, Helong, CA

EQUIPMENT:

GASCOM Model: $\quad$ GCM635 S/N: GCM635002

- VISIT-A; EVERY 3 MONTHS

A) CLEAN AIR ELEMENT ON COMPRESSOR \& ENGINE

B) TIGHTEN CYLINDER HEAD BOLTS

C) INSPECT OIL LEVEL ON COMPRESSOR

D) REPLACE ENGINE OIL

E) TIGHTEN DRIVE BELTS

F) TIGHTEN HOSES, CLAMPS \& MOUNTS

G) ADJUST MANN ENGINE VALVES

H) GREASE FAN SHAFT BEARINGS

I) CLEAN AIR COOLED COOLERS

J) INSPECT FOR GAS, OIL \& AIR LEAKS

K) CLEAN \& INSPECT COMPLETE UNIT

L) ADVISE OF ANY PROBLEMS

- VISIT-B; EVERY 6 MONTHS
A) SAME AS VISIT "A"
B) REPLACE COMPRESSOR OIL FILTER
C) CHECK COMPRESSION
D) CHECK IGNITION TIMING
E) CHECK THROTTLE SHAFT BUSHINGS
F) INSPECT EXHAUST SYSTEM
G) CLEAN RADIATOR FINS

- VISIT-C; EVERY 12 MONTHS 

A) SAME AS VISIT "B"
B) CLEAN INLET GAS STRAINER
C) REPLACE COMPRESSOR OIL
D) REPLACE SPARK PLUGS
E) REPLACE OXYGEN SENSOR
F) REPLACE ANTI-FREEZE
G) REPLACE ANODE ON COOLERS
H) REPLACE DISTRIBUTOR ROTOR \& CAP

The above service schedule is prepaid for the first 2 years of operation. The prepaid amount does not include any makeup lubricant or any other parts required that are not covered within the GASCOM warranty. 


\section{Appendix D: Natural Gas Engine Driven Air Compressor Data Logger Software}

PC208W Software Installation \& Operation

INSTALLATION

1. Insert PC208W Datalogger CD in the CD drive.

2. Installation program will automatically start. If not, click "Setup".

3. The "Welcome" screen will appear. Follow the prompted instructions.

4. After installation the new folders will be added to the main root directory:

5. Add the following files to the "PC208W" folder (or other destination folder later defined in "Setup").

1) SIAD.CSI

2) SIAD.DLD

3) SIAD.FSL

4) SIAD.PTI

Files are located in the "Energy Monitoring Manual" CD in the folder: 15-Data Acq IPC208W

SETUP \& OPERATION

1. Setup

1. Start PC208W program.

2. The main menu will appear:

3. Click "Setup".

4. The "Setup Connections" screen will appear:

5. Click "Add COM Port".

6. Set for COM1, COM2, COM3, etc.

7. Highlight COM port (e.g., COM3).

8. Click "Add Device".

9. Select "Phone Modem".

10. The "Attached Selected Device to" screen will appear.

11. Select the COM port (e.g., COM3).

12. Click "OK".

13. Select "Hardware" tab (default).

14. Enter name in the "Phone Modem Name" filed (e.g., Modem1).

15 Select the Baud Rate: 9600.

16. Select modem type in the "Modem Pick List" (refer to Windows Control Panel to determine modem type; if not listed select $<$ Default Modem>).

17. Highlight Modem name in the Device Map (e.g., Modem1).

18. Click "Add Device".

19. Select "CR10X Datalogger".

20. The "Attached Selected Device to" screen will appear.

21. Select the Modem (e.g., Modem1).

22. Click "OK".

23. Enter modem ID name in "CR10X Datalogger Name" field (e.g., SIAD). 
24. Enter site phone number in "Dialed Using Phone Number":

25. Enter/Verify parameters:

Security Code: 0

Call-back Id Number: 0

Clock Offset (ms): 0
Max Time Online (sec): 600

Max. Packet Size: 2048

Extra-Response Time (sec): 1000

26. Click "Data Collection" tab (lower screen).

27. Keep "Collect", "File Mode" and "File Format" at default settings.

28. To change destination of download file (e.g., SIAD.DAT), select "Browse" under "Data File Names for Areas 1 \& 2".

29. Click "Save Edits".

2. Operation

1. Click "Connect" in the main menu.

2. Highlight datalogger name in the "Station List" (e.g., SIAD).

3. Click the "Connect" box (lower right-hand corner).

4. Modem dial tones should be heard.

5. When connected, the 2 connector graphic will be joined and the text will read "Connected".

6a) To view data in real time, click the "Numeric" box (lower left side).

6b) To download data, click "Collect" box in the "Manual Data Collection" area. File name will be $<$ datalogger name>.DAT (e.g., SIAD.DAT).

7) Insert downloaded data into Excel file: "Energy Monitoring Template". Excel file is located in the "Energy Monitoring Manual" CD in the folder: 15-Data AcqlPC208W.

Manual Support

The following Campbell Scientific manuals are located in "Energy Monitoring Manual" CD in the folder: 15-Data Acq:

Hardware:

1) CR10X Operator's Manual

2) CR10X Prompt Sheet

3) COM210 Modem Manual

4) PS12 Power Supply Manual

Software:

1) PC208W Software Manual

Factory Support

Contact technical support at Campbell Scientific.

Software Code

Program: Sierra Army Depot-Engine-Drive Air Compressor

Flag Usage:

Input Channel Usage:

Excitation Channel Usage:

Control Port Usage:

Pulse Input Channel Usage:

Output Array Definitions:

* 1 Table 1 Programs

01:2 Sec. Execution Interval

01: $\mathrm{P} 30 \quad \mathrm{Z}=\mathrm{F}$

01: $2 \quad \mathrm{~F}$

02: 00 Exponent of 10

03: $28 \quad$ Z Loc [:scan secs] 
02: P3 Pulse

01: 1 Rep

02: 1 Pulse Input Chan

03: 2 Switch closure

04: 1 Loc [:F1 Gas ]

05: 10 Mult

06: 0.0000 Offset

03: P3 Pulse

01: 1 Rep

02: 2 Pulse Input Chan

03: 2 Switch closure

04: 2 Loc [:F2 HR ]

05: 10 Mult

06: 0.0000 Offset

04: P1 Volt (SE)

01: $1 \quad$ Rep

02: $25 \quad 2500 \mathrm{mV} 60 \mathrm{~Hz}$ rejection Range

03: 1 IN Chan

04: 3 Loc [:T inlet ]

05: 0.1563 Mult

06: -62.5 Offset

05: P1 Volt (SE)

01: 1 Rep

02: $25 \quad 2500 \mathrm{mV} 60 \mathrm{~Hz}$ rejection Range

03: 2 IN Chan

04: $4 \quad$ Loc [:T oulet ]

05: 0.1563 Mult

06: -62.5 Offset

06: P1 Volt (SE)

01: 1 Rep

02: $25 \quad 2500 \mathrm{mV} 60 \mathrm{~Hz}$ rejection Range

03: 3 IN Chan

04: 5 Loc [:T CA ]

05: 0.08125 Mult

06: -32.5 Offset

07: P1 Volt (SE)

01: $1 \quad$ Rep

02: $25 \quad 2500 \mathrm{mV} 60 \mathrm{~Hz}$ rejection Range

03: 4 IN Chan

04: 6 Loc [:T amb ]

05: 0.08125 Mult

06: -32.5 Offset

08: P1 Volt (SE)

01: $1 \quad$ Rep

02: $25 \quad 2500 \mathrm{mV} 60 \mathrm{~Hz}$ rejection Range

03: 5 IN Chan

04: 7 Loc [:RH amb ]

05: 0.0625 Mult

06: -25.0 Offset

09: P1 Volt (SE) 


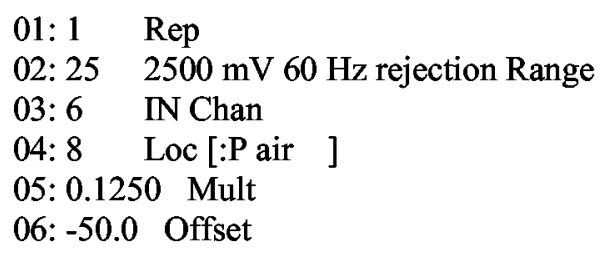

10: P2 Volt (DIFF)

01: 1 Rep

02: $25 \quad 2500 \mathrm{mV} 60 \mathrm{~Hz}$ rejection Range

03: 4 IN Chan

04: 9 Loc [:F air ]

05: 0.3750 Mult

06: -150.0 Offset

\author{
11: P2 Volt (DIFF) \\ 01: 1 Rep \\ 02: $25 \quad 2500 \mathrm{mV} 60 \mathrm{~Hz}$ rejection Range \\ 03: 5 IN Chan \\ 04: 10 Loc [: ] \\ 05: -1 Mult \\ 06: 0.0000 Offset \\ 12: P86 Do \\ 01: 01 Call Subroutine 1 Calculations \\ 13: P86 Do \\ 01: 2 Call Subroutine 2 Configure Output
}

14: P End Table 1

* 2 Table 2 Programs

01: 0.0000 Sec. Execution Interval

01: P End Table 2

* 3 Table 3 Subroutines

01: P85 Beginning of Subroutine Calculations

01: 1 Subroutine Number

02: $\mathrm{P} 33 \quad \mathrm{Z}=\mathrm{X}+\mathrm{Y}$

01: $1 \quad \mathrm{X}$ Loc F1 Gas

02: $11 \quad$ Y Loc Total F1

03: 11 Z Loc [:Total F1 ]
03: $\mathrm{P} 33 \quad \mathrm{Z}=\mathrm{X}+\mathrm{Y}$
01: $2 \quad \mathrm{X}$ Loc F2 HR
02: $12 \quad$ Y Loc Total F2
03: 12 Z Loc [:Total F2 ]
04: $\mathrm{P} 33 \quad \mathrm{Z}=\mathrm{X}+\mathrm{Y}$
01: $28 \quad X$ Loc scan secs
02: 29 Y Loc Totalsecs 


\section{3: $29 \quad$ Z Loc [:Totalsecs]}

05: $\mathrm{P} 37 \quad \mathrm{Z}=\mathrm{X} * \mathrm{~F}$

01: $29 \quad X$ Loc Totalsecs

02: $0.017 \quad \mathrm{~F}$

03: $30 \quad$ Z Loc [:Total min]

06: $\mathrm{P} 37 \quad \mathrm{Z}=\mathrm{X} * \mathrm{~F}$

01: $30 \quad X$ Loc Total min

02: $0.017 \quad \mathrm{~F}$

03: $31 \quad \mathrm{Z}$ Loc [:Total hr ]

07: $\mathrm{P} 38 \quad \mathrm{Z}=\mathrm{X} / \mathrm{Y}$

01: $11 \quad \mathrm{X}$ Loc Total F1

02: $31 \quad$ Y Loc Total hr

03: 13 Z Loc [:Gas CFH ]

08: $\mathrm{P} 38 \quad \mathrm{Z}=\mathrm{X} / \mathrm{Y}$

01: $12 \quad X$ Loc Total F2

02: $30 \quad$ Y Loc Total min

03: $14 \quad \mathrm{Z}$ Loc [:HR gpm ]

09: $\mathrm{P} 35 \quad \mathrm{Z}=\mathrm{X}-\mathrm{Y}$

01: $4 \quad X$ Loc T oulet

02: $3 \quad$ Y Loc T inlet

03: 15 Z Loc [:HR deltaT]

10: $\mathrm{P} 36 \quad \mathrm{Z}=\mathrm{X}^{*} \mathrm{Y}$

01: $14 \quad X$ Loc HR gpm

02: 15 Y Loc HR deltaT

03: $16 \quad Z$ Loc [:HR kBTUh ]

11: $\mathrm{P} 37 \quad \mathrm{Z}=\mathrm{X} * \mathrm{~F}$

01: $16 \quad X$ Loc HR kBTUh

02: $0.45 \quad F$

03: $16 \quad \mathrm{Z}$ Loc [:HR kBTUh ]

12: P95 End Subroutine 1

13: P85 Beginning of Subroutine Configure Output

01:2 Subroutine Number

14: P92 If time is

01: 0000 minutes into a

02: 15 minute interval

03: 10 Set high Flag 0 (output)

15: P77 Real Time

01: 1111 Year,Day,Hour-Minute,Seconds

16: P72 Totalize

01: $1 \quad$ Rep

02: 28 Loc scan secs

17: P72 Totalize

01:2 Reps 
02: 1-- Loc F1 Gas

18: P71 Average

01: 8 Reps

02: 3-- Loc $\mathrm{T}$ inlet

19: P70 Sample

01: 2 Reps

02: 13-- Loc Gas CFH

20: P70 Sample

01: 1 Reps

02: 16 Loc HR kBTUh

21: P91 If Flag/Port

01: 10 Do if flag 0 (output) is high

02: 30 Then Do

22: $\mathrm{P} 30 \quad \mathrm{Z}=\mathrm{F}$

01: $0 \quad \mathrm{~F}$

02: 00 Exponent of 10

03: 11 Z Loc [:Total F1 ]

23: $\mathrm{P} 30 \quad \mathrm{Z}=\mathrm{F}$

01: $0 \quad \mathrm{~F}$

02: 0 Exponent of 10

03: 12 Z Loc [:Total F2 ]

24: $\mathrm{P} 30 \quad \mathrm{Z}=\mathrm{F}$

01: $0 \quad \mathrm{~F}$

02: $0 \quad$ Exponent of 10

03: 29 Z Loc [:Totalsecs]

25: P95 End if port

26: P95 End Subroutine 2 configure output

27: P $\quad$ End Table 3

* A Mode 10 Memory Allocation

01: 35 Input Locations

02: 64 Intermediate Locations

03: 0.0000 Final Storage Area 2

* C Mode 12 Security

01: 0000 LOCK 1

02: 0000 LOCK 2

03: 0000 LOCK 3

Input Location Assignments (with comments):

Key: 
$\mathrm{T}=$ Table Number

$E=$ Entry Number

$\mathrm{L}=$ Location Number

T: E: L:

1: 2: 1: Loc [:F1 Gas ]

1: 3: 2: Loc [:F2 HR ]

1: 4: 3: Loc [:T inlet ]

1: 5: 4: Loc [:T oulet ]

1: 6: 5: Loc [:T CA ]

1: 7: 6: Loc [:T amb ]

1: 8: 7: Loc [:RH amb ]

1: 9: 8: Loc [:P air ]

1: 10: 9: Loc [:F air ]

1: 11: 10: Loc [:

3: 2: 11: Z Loc [:Total F1 ]

3: 22: 11: Z Loc [:Total F1 ]

3: 3: 12: Z Loc [:Total F2 ]

3: 23: 12: Z Loc [:Total F2 ]

3: 7: 13: Z Loc [:Gas CFH ]

3: 8: 14: Z Loc [:HR gpm ]

3: 9: 15: Z Loc [:HR deltaT]

3: 10: 16: Z Loc [:HR kBTUh ]

3: 11: 16: Z Loc [:HR kBTUh ]

1: 1:28: Z Loc [:scan secs]

3: 4: 29: Z Loc [:Totalsecs]

3: 24: 29: Z Loc [:Totalsecs]

3: 5: 30: Z Loc [:Total min]

3: 6: 31: Z Loc [:Total hr ] 


\section{CERL Distribution}

Commander, Rock Island Arsenal

ATTN: AMXIS-C (2)

Installation Management Agency

ATTN: Operations Division

ATTN: Northeast Regional Office

ATTN: Northwest Regional Office

ATTN: Southeast Regional Office

ATTN: Southwest Regional Office

ATTN: Europe Regional Office

ATTN: Pacific Regional Office

ATTN: Korea Regional Office

Chief of Engineers

ATTN: CEHEC-IM-LH (2)

Engineer Research and Development Center (Libraries)

ATTN: ERDC, Vicksburg, MS

ATTN: Cold Regions Research, Hanover, NH

ATTN: Topographic Engineering Center, Alexandria, VA

Defense Tech Info Center 22304

ATTN: DTIC-O

15

$01 / 03$ 


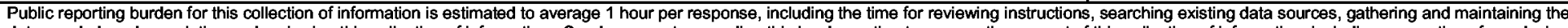

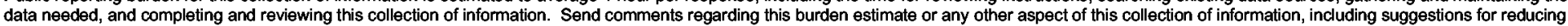

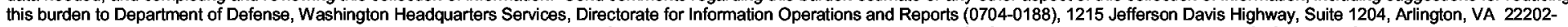

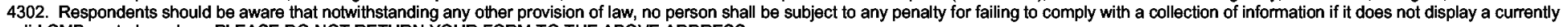
valid OMB control number. PLEASE DO NOT RETURN YOUR FORM TO THE ABOVE ADDRESS.
1. REPORT DATE (DD-MM-YYYY)
2. REPORT TYPE
Final
3. DATES COVERED (From - To)
15Aug02 - 31 Jan03
4. TITLE AND SUBTITLE

Final
5a. CONTRACT NUMBER

Demonstration of Natural Gas Engine Driven Air Compressor at Army Industrial Facilities

5b. GRANT NUMBER

5c. PROGRAM ELEMENT NUMBER

6. AUTHOR(S)

Mike C.J. Lin, Stephen J. Aylor, Robert T. Lorand, John C. Skelton, Hank Van Ormer, Paul

A. Wenner, George Powers, Donald Carlson, William R. King, and John F. Westerman

\section{5d. PROJECT NUMBER}

MIPR

5e. TASK NUMBER

1B6AR4D125

5f. WORK UNIT NUMBER

8. PERFORMING ORGANIZATION REPORT NUMBER

ERDC/CERL TR-03-2

\section{U.S. Army Engineer Research and Development Center (ERDC)}

Construction Engineering Research Laboratory (CERL)

PO Box 9005

Champaign, IL 61826-9005

\section{SPONSORING / MONITORING AGENCY NAME(S) AND ADDRESS(ES)}

Rock Island Arsenal

1 Rock Island Arsenal

Rock Island, IL 61299-7190

10. SPONSOR/MONITOR'S ACRONYM(S)

AMXIS-C

11. SPONSOR/MONITOR'S REPORT NUMBER(S)

\section{DISTRIBUTION / AVAILABILITY STATEMENT}

Approved for public release; distribution is unlimited.

\section{SUPPLEMENTARY NOTES}

Copies are available from the National Technical Information Service, 5285 Port Royal Road, Springfield, VA 22161.

\section{ABSTRACT}

The use of air compressors by the DOD is widespread, and the variety of tools and machinery that operate on compressed air is increasing. Air compressors are commonly driven by electric motors, even though the energy cost of operating a natural gas fueled engine-driven air compressor is usually lower than the cost of operating an electric motor driven unit. Moreover, natural gas is a cleanburning, abundant, and readily available fuel. This study was undertaken to demonstrate the economic benefits of using a natural gas engine driven air compressor to meet air compressor needs in a representative Army industrial environment, and to evaluate the natural gas fueled technology in terms of operation and maintenance (O\&M), compressed air quality, efficiency, reliability, air emissions, and economic feasibility.

\section{SUBJECT TERMS}

Army facilities

air compressor

16. SECURITY CLASSIFICATION OF:

a. REPORT
Unclassified

b. ABSTRACT

Unclassified industrial facilities

natural gas

c. THIS PAGE

Unclassified
17. LIMITATION OF ABSTRACT

SAR
Army Material Command (AMC)

NGEDAC
8. NUMBER

148 19a. NAME OF RESPONSIBLE PERSON

Mike C.J. Lin

19b. TELEPHONE NUMBER (include area code)

217-352-6511, x-7358 